\title{
COST-BENEFIT ANALYSIS OF GREENING AN OLDER MODEST-SIZED HOME
}

\section{IN THE SAN FRANCISCO BAY AREA}

\author{
A Professional Project Presented To the Faculty of \\ California Polytechnic State University San Luis Obispo \\ In Partial Fulfillment of the Requirements for the Degree \\ Master of City and Regional Planning
}

Prepared by

Delilah Zoe Leval

October 2010 
(c) 2010

Delilah Zoe Leval

ALL RIGHTS RESERVED 
COMMITTEE MEMBERSHIP

TITLE:

Cost Benefit Analysis of Greening a Modest-Sized Older Home in the San Francisco Bay Area

AUTHOR:

Delilah Zoe Leval

DATE SUBMITTED:

October 112010

COMMITTEE CHAIR: Michael Boswell, Associate Professor

COMMITTEE MEMBER: Adrienne Greve, Assistant Professor

COMMITTEE MEMBER: Tom Di Santo, Associate Professor 


\section{Abstract \\ COST-BENEFIT ANALYSIS OF GREENING AN OLDER MODEST-SIZED HOME \\ IN THE SAN FRANCISCO BAY AREA \\ Delilah Zoe Leval}

This professional project estimates the upfront costs and utility savings expected from greening an approximately 1,100 square foot home built in the 1950 s in the San Francisco Bay Area. Two sets of upgrades (alternative and original) were compared for costs and benefits. The alternative set (which included ceiling insulation and omitted upgrading to dual-pane windows) clearly out performed the original set. The alternative set would be expected to reduce resident utility bills by $28 \%$ annually, and to prevent approximately $2,700 \mathrm{lbs}$ of carbon dioxide emissions annually. The water efficiency upgrades were the best performing group of upgrades, as they had the lowest upfront cost and shortest payback period. (These water efficiency upgrades consisted of modifying toilets, faucets, and showerhead, as well as upgrading the dishwasher and clothes washer to efficient models.) Future very low-budget greening programs, in nearly all cases, should include a full-set of water fixture modifications, weatherstripping, and clotheslines. As budgets allow, other upgrades from alternative upgrades list are recommended, such as ceiling fans, programmable thermostats, and ceiling insulation. Whenever possible, workforce development labor should be used to simultaneously reduce labor costs and multiply the social benefit of each project dollar by providing entry-level green collar jobs.

Keywords: Affordable housing, low-income, moderate-income, established neighborhood, Richmond, California, Bay Area, 1950s, small homes, green, energy efficiency, water efficiency, environment, greenhouse gases, cost-benefit analysis. 


\section{Acknowledgements}

I would like to acknowledge the Contra Costa County Conservation and Development Department, particularly Jim Kennedy, Kara Douglas, Gabriel Lemus, and David Brockbank. I am truly impressed with your dedication and have appreciated your support. I would also like to an extend thanks to all Contra Costa Consortium members, Gloria Slusher in particular, for your hard work on the 2009 NSP2 application.

Thank you Dr.Tom Di Santo for imparting me so many lessons on architecture in such a compressed amount of time, and for your very generous spirit. Dr. Adrienne Greve and Dr. Michael Boswell, thank you for sharing your invaluable guidance and thoughtful feedback.

Lastly, but certainly not least, I thank the Higher Power and my family. 


\section{Table of Contents}

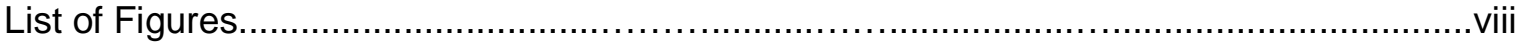

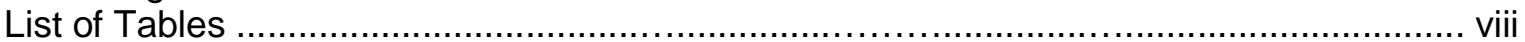

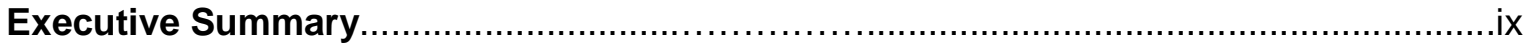

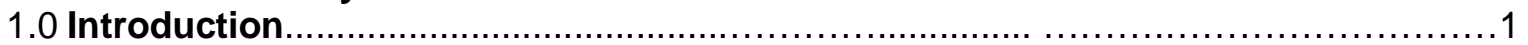

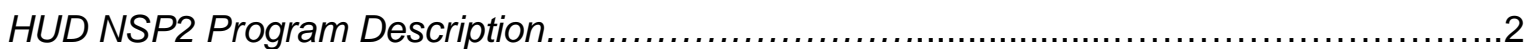

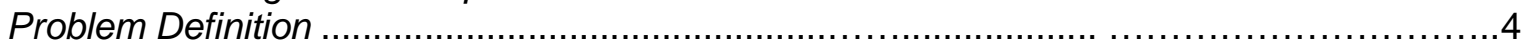

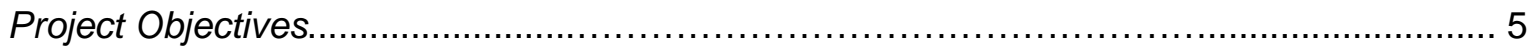

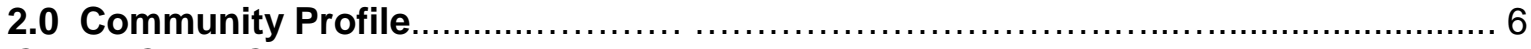

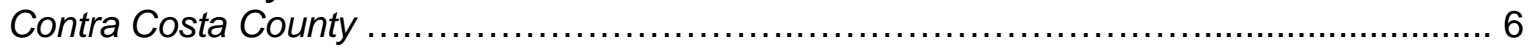

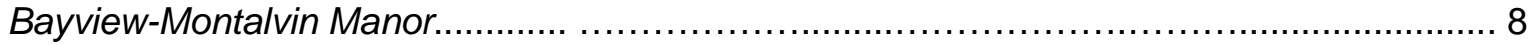

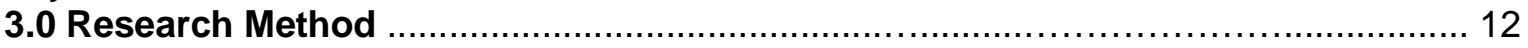

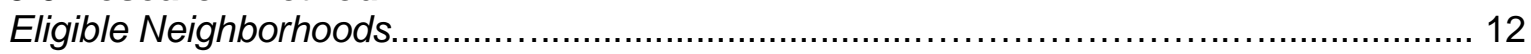

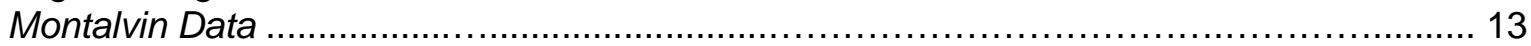

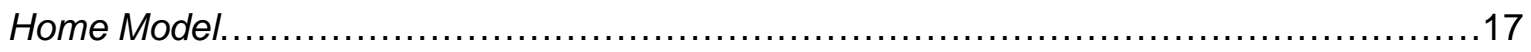

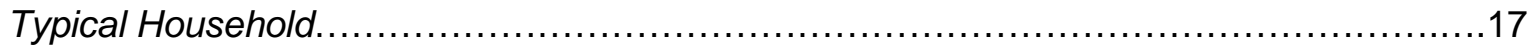

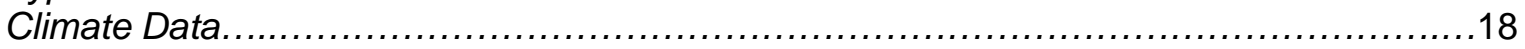

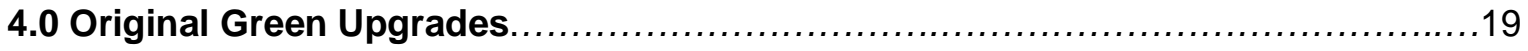

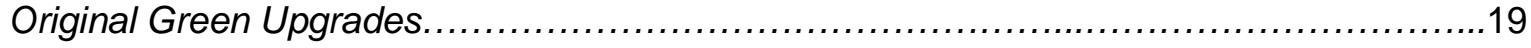

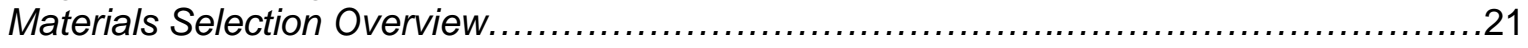

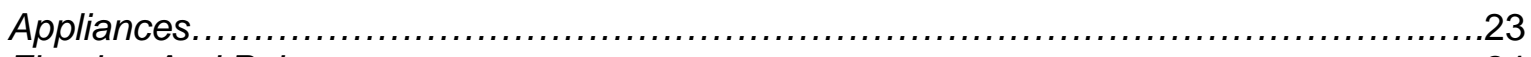

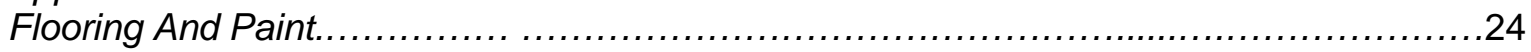

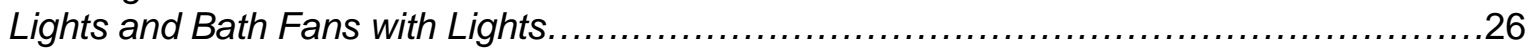

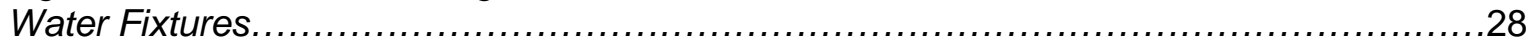

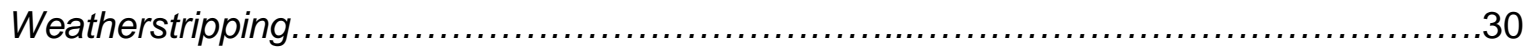

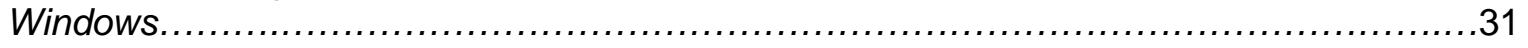

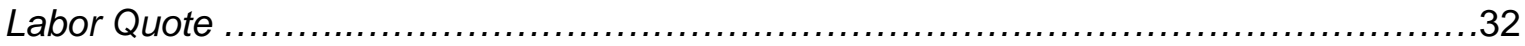

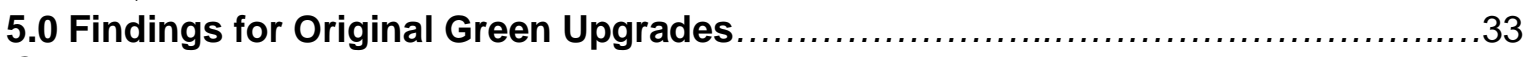

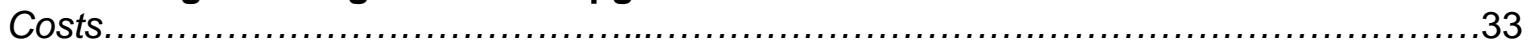

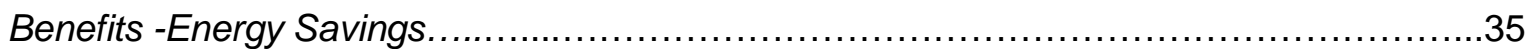

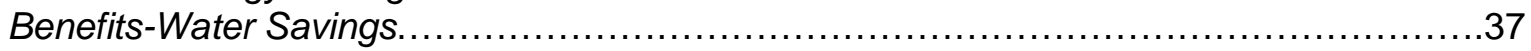

Summary of Benefits from Original Upgrades............................................. 38

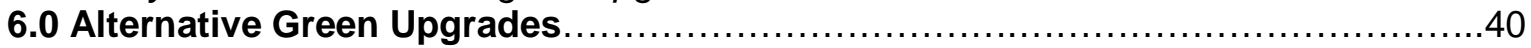

Material Selection and Labor Cost Estimation............................................. 41

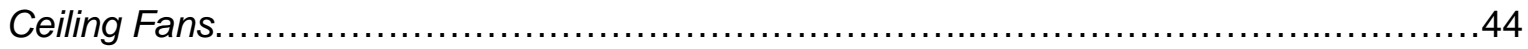

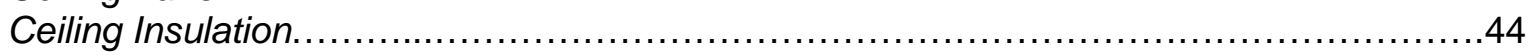

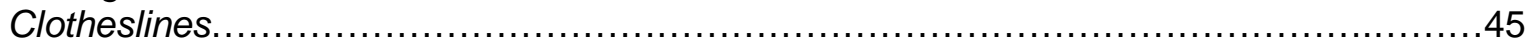

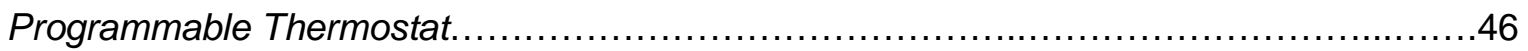

Kitchen Faucet Aerator...................................................................... 46

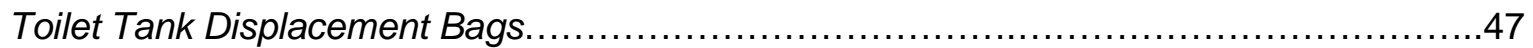

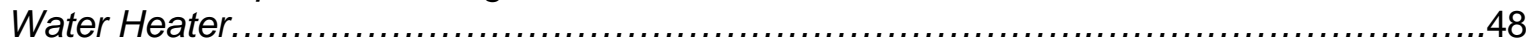

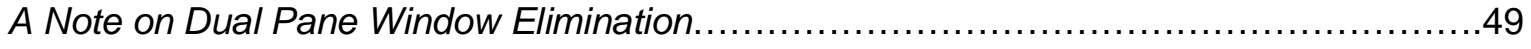

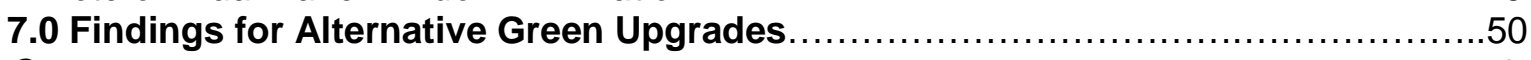

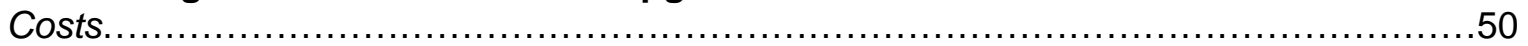

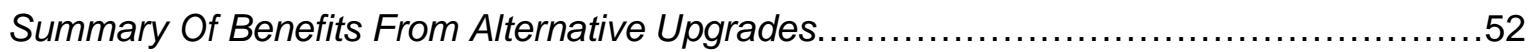

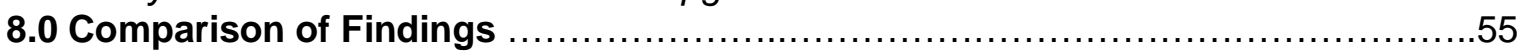

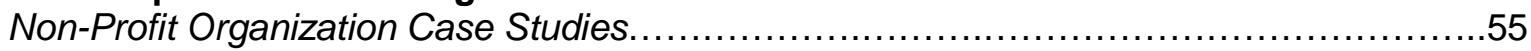

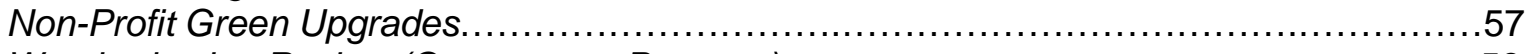

Weatherization Review (Government Program) ............................................. 58 


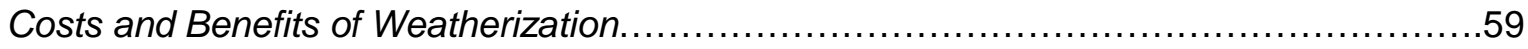

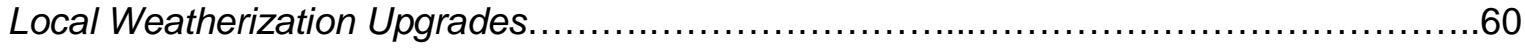

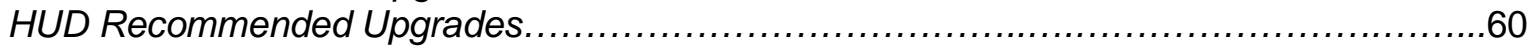

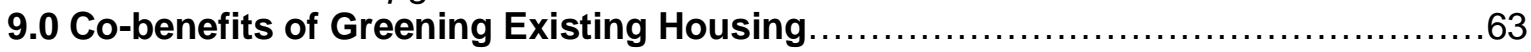

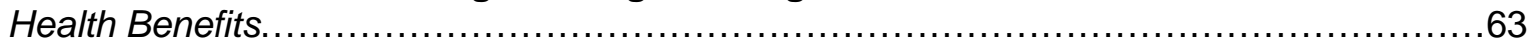

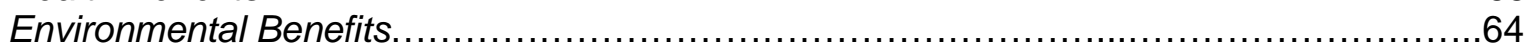

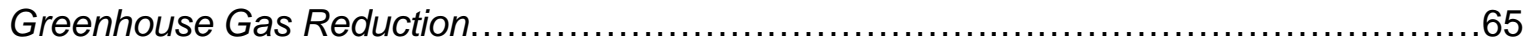

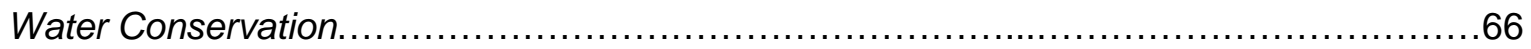

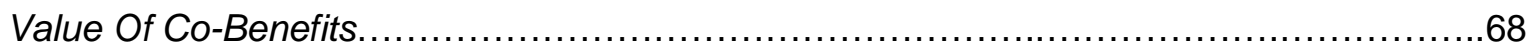

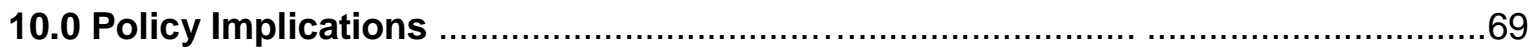

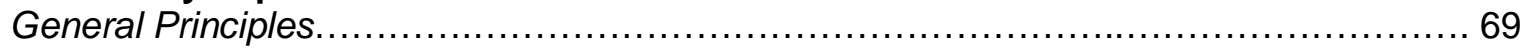

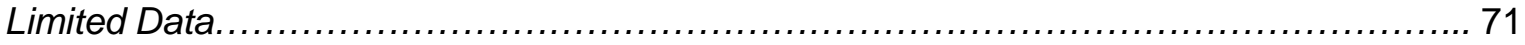

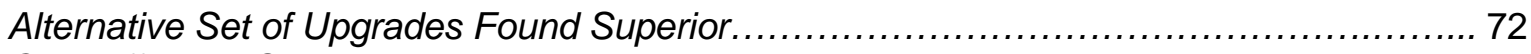

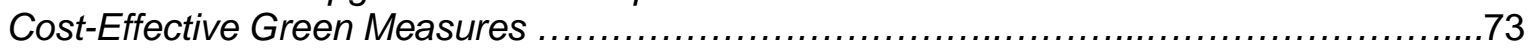

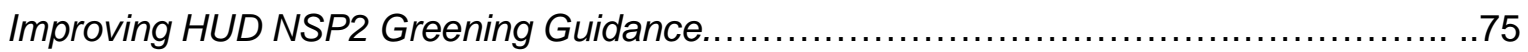

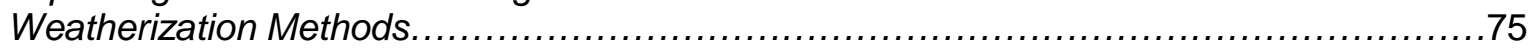

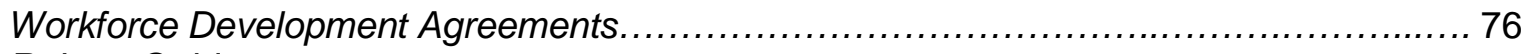

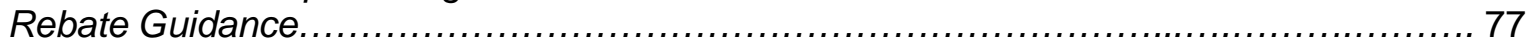

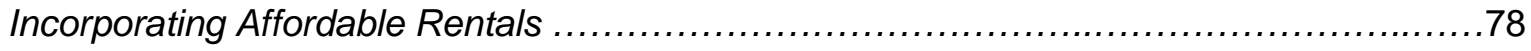

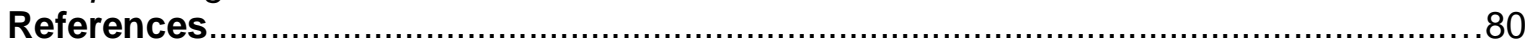

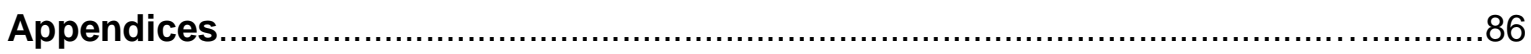

Appendix A1- Labor \& material costs for green upgrades and conventional equivalents.....86

Appendix A2- Labor \& material costs for alternative upgrades cost...........................87

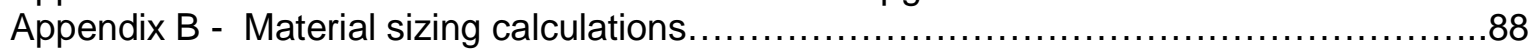

Appendix C - Labor solicitation spreadsheet for green and conventional upgrades...........93

Appendix D1 - Home Energy Saver Report - baseline configuration ..........................95

Appendix D2 - Home Energy Saver Report - original upgrades configuration................113

Appendix D3 - Home Energy Saver Report - alternatives upgrades configuration............129

Appendix E - Water usage under baseline, original and alternative configurations..........143 


\section{List of Figures}

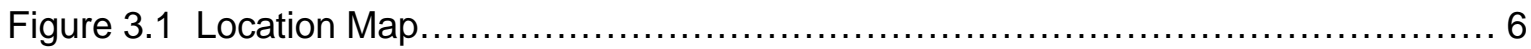

Figure 3.2 Foreclosures In 2008 In Contra Costa County......................................

Figure 3.3 Aerial Map Of Bayview-Montalvin Manor...........................................

Figure 3.4 House Size Distribution In Montalvin............................................ 10

Figure 3.5 Number Of Bedrooms Per Home, Distribution In Montalvin........................10

Figure 3.6 Interior Floor Plan For Montalvin Neighborhood Home On Karen Road............15

Figure 3.7 Historic Richmond Annual Temperature Regime................................ 18

Figure 4.1 Original Green Upgrades Commitment From CCC NSP2 Application..............20

\section{List of Tables}

Table 3.1 Census Tract 3640.01 Population Data For 2000 ................................

Table 4.1 Costs For Green And Conventional Models Of Household Appliances.............23

Table 4.2 Costs For Green And Conventional Models Of Flooring And Paint................24

Table 4.3 Costs For Green And Conv. Models Of Lights And Lights With Fans...............26

Table 4.4 Costs For Green And Conventional Models Of Water Fixtures.....................28

Table 4.5 Comparison Of Water Flow Rates Standards For Devices, In GPM...............29

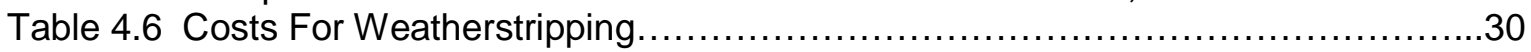

Table 4.7 Costs For Green And Conventional Models Of Windows.............................31

Table 5.1 Summary Of Original Green Upgrade Costs, With Conventional Equivalents.....33

Table 5.2 Est. Utility Use, GHG Emissions Of Baseline \& Original Upgrades.................38

Table 5.3 Estimated Payback Periods For Original Upgrades, By Sector......................38

Table 6.1 Alternative Green Upgrades, As Compared To Original Green Upgrades.........40

Table 6.2 Ceiling Fan Materials And Installation Cost........................................43

Table 6.3 Bulb Replacement Scheme For Ceiling Fans And Energy Star Fixtures. ..........44

Table 6.4 Ceiling Insulation Materials And Labor Cost.......................................44

Table 6.5 Clothesline Materials And Installation Cost..........................................45

Table 6.6 Programmable Digital Thermostat Materials And Installation Cost.................46

Table 6.7 Kitchen Faucet Aerator Materials And Installation Cost..............................46

Table 6.8 Toilet Tank Displacement Materials And Installation Cost.........................47

Table 6.9 Water Heater Materials And Installation Cost....................................48

Table 7.1 Alternative Upgrade Set Itemized Material And Labor Costs.......................50

Table 7.2. Est. Utility Usage \& GHG Emissions Of Baseline, Original, \& Alt. Upgrades........52

Table 7.3 Estimated Payback Periods For Alternative Upgrades, By Sector..................52

Table 8.1 Rehabilitation Case Studies Summary..............................................55

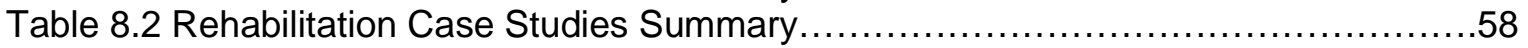




\section{Executive Summary}

Cost-Benefit Analysis of Greening an Older Modest-Sized Home in the San Francisco Bay Area

Delilah Zoe Leval

This professional project provides estimated upfront costs and future utility savings expected from upgrading an older, modest-sized home with certain green features. A home model was created based on available data for an established Bay Area neighborhood of single family homes built in the 1950s near Richmond, California. The model represents the neighborhood's average home dimensions and structural features. Materials and labor costs were estimated for two sets of green upgrades to improve water efficiency, energy efficiency, and indoor air quality of the home model. The original green upgrades were based on a series of upgrades devised in 2009 by Contra Costa County for a related HUD grant. The alternative green upgrades were a variation on the original series, modified with what were hypothesized to be less expensive, better performing measures. The "green premium," which is the average cost difference between green and conventional upgrades (comparable non-green versions) was also determined.

The following approach was used to estimate costs and benefits. First, material costs for both green and conventional upgrades were estimated by selecting economy models at a popular retailer and recording the list price. This information was used to obtain labor quotes from a reputable Bay Area contractor previously used by Contra Costa County. To estimate utility usage changes, parameters representative of the different home configurations were input into online energy and water savings calculators (created and endorsed by US government agencies). The cost and savings figures generated for this study's home model were then compared to case studies of greened existing housing in both the non-profit and government sectors. In addition, prior 
research on the health and environmental co-benefits of improved indoor air quality, home warmth, and resource conservation were discussed. Finally, policy implications were drawn from the findings, and specific recommendations on how to formulate the most cost-effective sets greening measures were provided.

The study concludes that the alternative upgrades, which are a variation on the original upgrades, were superior to the original upgrades. The alternative set of upgrades, which could tailored to meet the needs of future green retrofitting programs, is detailed in Appendix 2 . The estimated cost (labor and materials combined) to implement the original green upgrades in the County's NSP2 application was $\$ 24,501$. The alternative upgrade set had an estimated cost of approximately $\$ 4,100$ less, at $\$ 20,367$. Further, the original upgrades were projected to save the residents $\$ 517$ over baseline annual utility bills, whereas the alternative upgrades were projected to save the residents $\$ 740$ over baseline annual utility billsa difference of over $\$ 200$ in additional savings per year, reducing utility costs by $28 \%$. The green premium (the average additional upfront cost of choosing a green model over a conventional model) was estimated to be $\$ 363$, or an average of $41 \%$ over the conventional equivalent. Additionally, the alternative upgrades would save an estimated 2,700 lbs of carbon dioxide per upgraded home (annually) due to reduced electricity generation, lessening housing stock's contribution to anthropogenic climate change.

Other important monetary benefit findings were made when costs and benefits were divided across improvement sector (energy, water, and indoor air quality). The alternative water sector upgrades had the shortest payback period, at approximately 6.4 years. This suggests water sector upgrades, as a category, are the green upgrades from a financial investment perspective. Among the individual energy sector upgrade measures, according to the literature and academic opinion, blown-in ceiling insulation has the greatest savings potential and cost-effectiveness. The indoor air quality upgrades proved to be the most expensive individual upgrades, and their benefits were difficult to quantify, as they are thought to improve respiratory health. It was also determined that labor contributed between 
half and two-thirds of implementation cost. Future research which more thoroughly investigates the cost-benefit performance of a wider range of indoor air quality measures would be valuable to the field.

To formulate the most cost-effective greening program strategies, program planners are encouraged to 1) incorporate weatherization energy efficiency improvement measures, 2) source labor from workforce development programs, and 3) adopt greening measures like those in the alternative upgrade set in this study (see detailed product information and pricing in Appendix 2). In nearly all cases, low-cost green upgrade programs should include a full set of water saving devices, weatherstripping, clotheslines, and blown-in cellulose ceiling insulation. As budgets allow, additional energy saving measures from the alternative set such as digital thermostats, ceiling fans, and Energy Star rated refrigerators should be incorporated. As available, local weatherization methodology should be incorporated. Finally, when homes are located in areas with poor air quality, or if residents suffer from respiratory ailments, upgrade programs should include air quality measures, which can include measures such as removing carpeting and using only low VOC flooring, paints, and finishes. 


\section{Chapter 1.0 - Introduction}

This professional project provides estimated upfront costs, future utility savings, and greenhouse gas emission reductions expected from upgrading an older, modest-sized home with green features. These findings are combined with case studies of previously greened or weatherized dwellings and professional literature and expertise to formulate a cost-effective approach to green retrofitting. The study concludes with policy recommendations for HUD on improving its greening guidance in future programs.

The following describes the cost-benefit methodology used. A home model was created based on available data for an established Bay Area neighborhood of single family homes built in the 1950s near Richmond, California, in Contra Costa County. The model represents the neighborhood's typical home dimensions and structural features. Upfront costs consisting of material and labor costs were estimated for two sets of green upgrades intended to improve water efficiency, energy efficiency, and indoor air quality. The first set of green upgrades analyzed is the original upgrades proposed in a 2009 HUD grant application from Contra Costa County. The second set of green upgrades analyzed, the alternative set, is a variation on the original set based on recommendations from professional, government, and academic sources. The alternative set also fulfills the 2009 HUD grant application criteria. In addition, a series of upgrades analogous to the original green upgrades set but conventional (i.e., not energy or water efficient) were cost estimated for comparison to determine the "green premium" (the cost difference between green and conventional upgrades). Online energy and water usage calculators from US government agencies were used to estimate utility usage under for the home under baseline conditions and configured with the two green upgrade sets. In turn, these utility usage figures were used to estimate projected annual savings on utility bills, payback periods for the green upgrades, and tenyear savings (corrected for net present value). Non-monetary benefits established by 
previous research on the health benefits of improved indoor air quality and home warmth are also presented. The set of green upgrades that yields the highest estimated cost-benefit ratio is identified.

\section{HUD NSP2 Program Description}

In May of 2009 the US Department of Housing and Urban Development (HUD) released notification that it would fund local government efforts to purchase and rehabilitate (repair) foreclosed homes in low-income neighborhoods suffering under high concentrations of vacancy and foreclosure, associated with the recession (HUD, 2009a). The improved homes were then to be resold as affordable houses to qualified buyers (such as first-time homebuyers and low-income families). The program, called Neighborhood Stabilization Program 2 (NSP2), was the second version of a similar program, this time funded through ARRA (American Recovery and Reinvestment Act of 2009, a Congressional Act). The second version of NSP was a competitive grant program with a newly added dimension: a directive to "green" these existing buildings.

According to the EPA and academic literature, green buildings use resources efficiently, reduce waste, and protect occupant health, and are thus environmentally responsible (EPA, 2010a; Retzlaff, 2009). Buildings account for $68 \%$ of electricity usage, $12 \%$ of water usage, and $38 \%$ of carbon dioxide emissions in the United States, thus improving their resource efficiency holds great promise for reducing environmental degradation (EPA, 2010a). The NSP2 HUD funding notice specifies energy efficiency, water efficiency, and improved indoor air quality as its greening objectives.

In its notification, HUD specifically encourages use of Energy Star labeled appliances (which perform better using less energy than comparable devices) and following the nonprofit group Enterprise's "Green Community" list, which is a touted as a series of moderately priced green modifications (Energy Star, n.d a; Enterprise, 2008; HUD, 2009a, p. 28-29). Other examples of modifications that would meet these criteria could include replacing 
incandescent light bulbs with compact fluorescent light bulbs (CFLs), which use $75 \%$ less energy, replacing existing water fixtures with low-flow verisons, and repainting surfaces with paint free of VOC (volatile organic compound) fumes which aggravate asthma (EPA, 2010b). Further discussion of the merits of particular green building modification measures is presented in later chapters.

The County ${ }^{1}$ formulated its green upgrades approach for NSP2 under a tight deadline and without the advantage of a case study on low-cost greening of modest-sized singlefamily homes or even rough cost estimates. Guidance on affordable green upgrades for single-family homes was sought from the websites of two green building organizationsEnterprise Green Communities (which HUD recommended) and GreenPoint Ratings (cited in the County application). However, both suggested several major upgrades that were perceived as too expensive, and neither resource provided any pricing guidance (BuilditGreen, 2007; Enterprise, 2008). Thus in formulating the green upgrades of its commitment list for the greening element, the County chose upgrades from among those suggested from GreenPoint Rating, Enterprise Green Communities, and the HUD notification, using best personal judgment.

This study helps to fill the information gap with a cost-benefit analysis of the low cost green upgrades to which the County committed, from the perspective of the homeowner, the affordable housing organization, and the policy maker. Based on the literature search done for this professional project in late 2009, published peer reviewed academic literature on greening affordable housing was scarce. Professional resources on green affordable housing were also unhelpful, as they primarily addressed new construction, or greening

\footnotetext{
${ }^{1}$ The Contra Costa Consortium consists of the Cities of Antioch, Pittsburg, Richmond, Walnut Creek, as well as Contra Costa County "urban area" (urbanized areas within the County limits) (Contra Costa Consortium [CCC], 2009, p6). These entities jointly applied for NSP2 funds. For the sake of simplicity, and because Contra Costa County was the designated lead applicant, this study refers to Contra Costa County ("the County") as the decision body and author of the 2009 NSP2 application.
} 
apartment units, not existing modest-sized single-family homes. Few papers or articles addressed the informational needs of the Neighborhood Stabilization Program, as most of the work done through the program is likely to be greening modest-sized, existing singlefamily homes. This study will give affordable housing professionals a starting point from which to formulate a low cost yet effective greening program feasible when given a modest project budget. Finally, it will reflect on the policy decision to add a green element to this affordable housing program, and how the HUD Neighborhood Stabilization Program guidance and notification could have been improved.

\section{Problem Definition}

The NSP2 application required jurisdictions to make a commitment statement that specified how many units they would purchase, repair, upgrade with green features, and help finance; the County committed to 250 units. The County was also required to draft a budget allocating money to each program component which matched the total grant dollar amount requested; the County requested the maximum budget limit of $\$ 50$ million and committed itself to a budget of $\$ 250,000$ per home ${ }^{2}$. The County allocated a budget of $\$ 15,000$ per home for green upgrades, based on the planners' experience of pricing green upgrades for their own residences. The County consulted the Enterprise Green Communities publication (referenced in the HUD funding notification) and BuilditGreen's GreenPoint Rating for what specific upgrades to perform, but neither of these guides provided price ranges for the upgrades they recommend, thus their help in building the greening budget was negligible (HUD, 2009a, p. 29; Enterprise, 2008). The County chose to commit to the following green upgrades, selected from a sample list in the funding notification (HUD, 2009, p. 14; CCC, 2009, p. 34): renewable flooring, low VOC paint, windows, weatherstripping, WaterSense fixtures, and Energy Star rated light fixtures and other appliances. Competition for federal dollars to improve foreclosed homes was very

\footnotetext{
${ }^{2}$ One budget assumption was that homes repaired and sold earlier through the program would fund homes entering the program later.
} 
strong in 2009, and Contra Costa County was not selected as a federal grant recipient, despite the considerable number of foreclosed homes in the area.

In ideal circumstances, jurisdictions participating in NSP2 would have had researchbacked guidance as to which upgrades are the most affordable and cost-effective, so that project dollars would be spent efficiently and used to the greatest public benefit possible. Further, a greening budget would have ideally been based on local material and labor cost estimates specific to the homes in the nominated Census Tracts, using typical home dimensions and construction type.

\section{Project Objectives}

This study will help fill the information gap of the cost-effectiveness of greening existing modest single-family homes on a small budget by providing a hypothetical case study. Estimated material and labor costs and expected future utility bill savings will be generated for two sets of green upgrades applied to a home model representative of a nominated neighborhood. These two sets are 1) the original green upgrades from the Contra Costa County NSP2 grant proposal, and 2) an alternative set of green upgrades based on recommendations from Professor Di Santo, professional literature and academic literature. A set of conventional (non-green) upgrades is used for material and labor cost comparisons as well. This study will be of particular interest to Contra Costa County, but other groups looking for estimated costs for green upgrades to small homes will benefit as well. The project will provide the following information:

1. An estimated cost for materials and labor for the original green upgrades to which the County committed, and an alternative set of green upgrades (per upgraded unit).

2. A cost comparison between the original green upgrades proposed and their conventional counterparts.

3. A projection of long-term operation cost savings for the original and alternative green upgrades (per unit), with additional estimates for savings in kilowatts, BTUs, gallons of water, and greenhouse gases emissions prevented (as applicable).

4. A description of health and environmental benefits associated with green housing. 


\section{Chapter 2.0 - Community Profile}

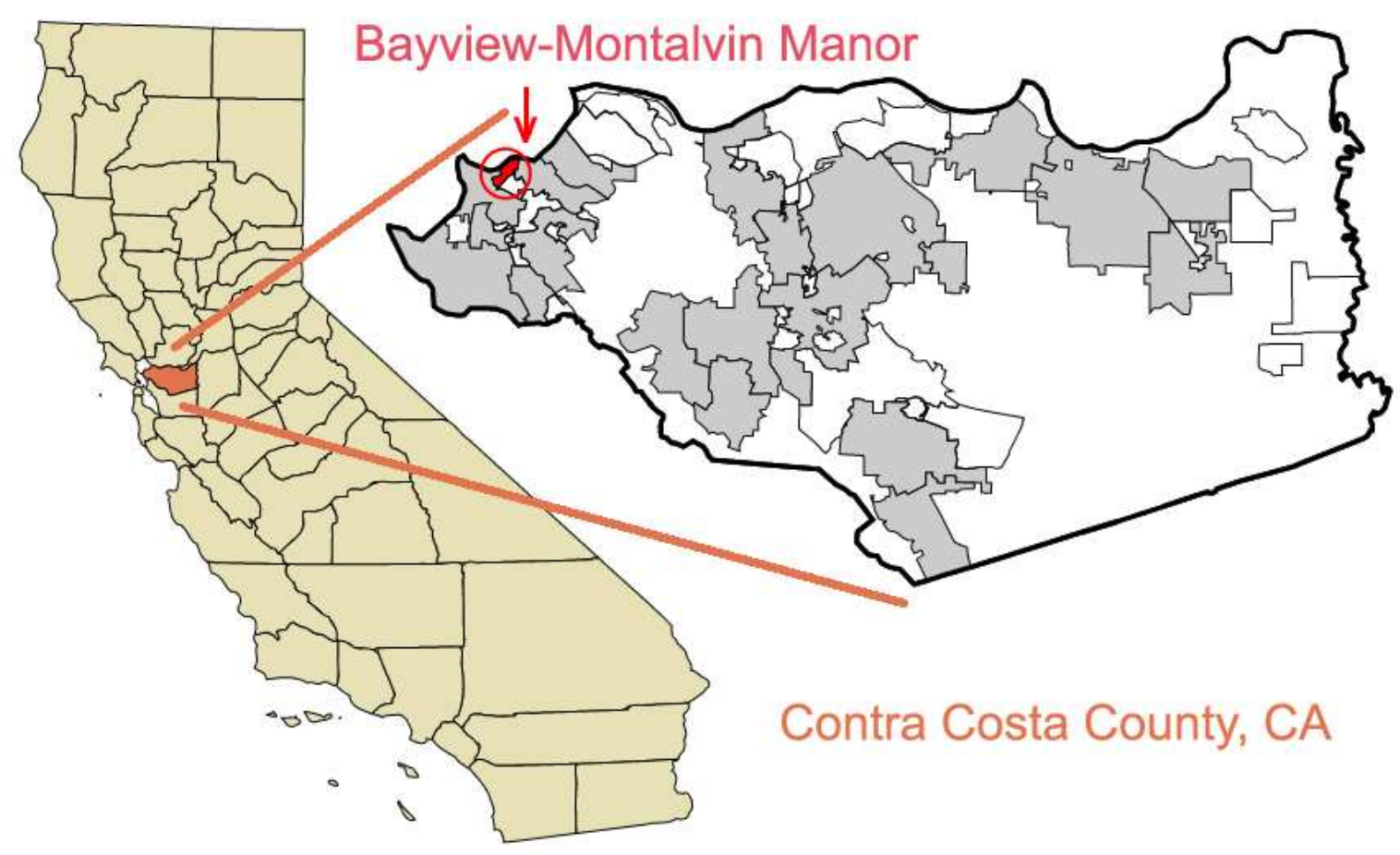

Figure 3.1 : Location Map. Indicates Contra Costa County's location in the state, and Montalvin's location in the County. Incorporated cities shaded. Source: Contra Costa County, 2009.

\section{Contra Costa County}

Contra Costa County is located in Northern California, and is one of the nine counties that make up the San Francisco Bay Area (see Figure 3.1). The County covers 733 square miles and in 2009 had an estimated population of 1,041,274 (US Census, 2010). Contra Costa County's land uses are diverse; the far western and northern portions host heavy industry (such as oil refineries), its far eastern areas are still primarily rural/agricultural, while its center is dominated by suburban/residential neighborhoods and commercial with pockets of light industry (CCC, 2009). Areas under jurisdiction of County planning include not only the unincorporated rural areas mostly in the east (white areas in Figure 3.1), but also unincorporated "urbanized areas"-suburban or industrial areas that lie directly across the 
borders of incorporated cities (gray areas in Figure 3.1). Examples of these urbanized unincorporated communities are Bayview-Montalvin Manor (indicated in red in Figure 3.1, located next to San Pablo), Bay Point (next to Pittsburg), North Richmond (next to Richmond), and Rodeo (next to Pinole).

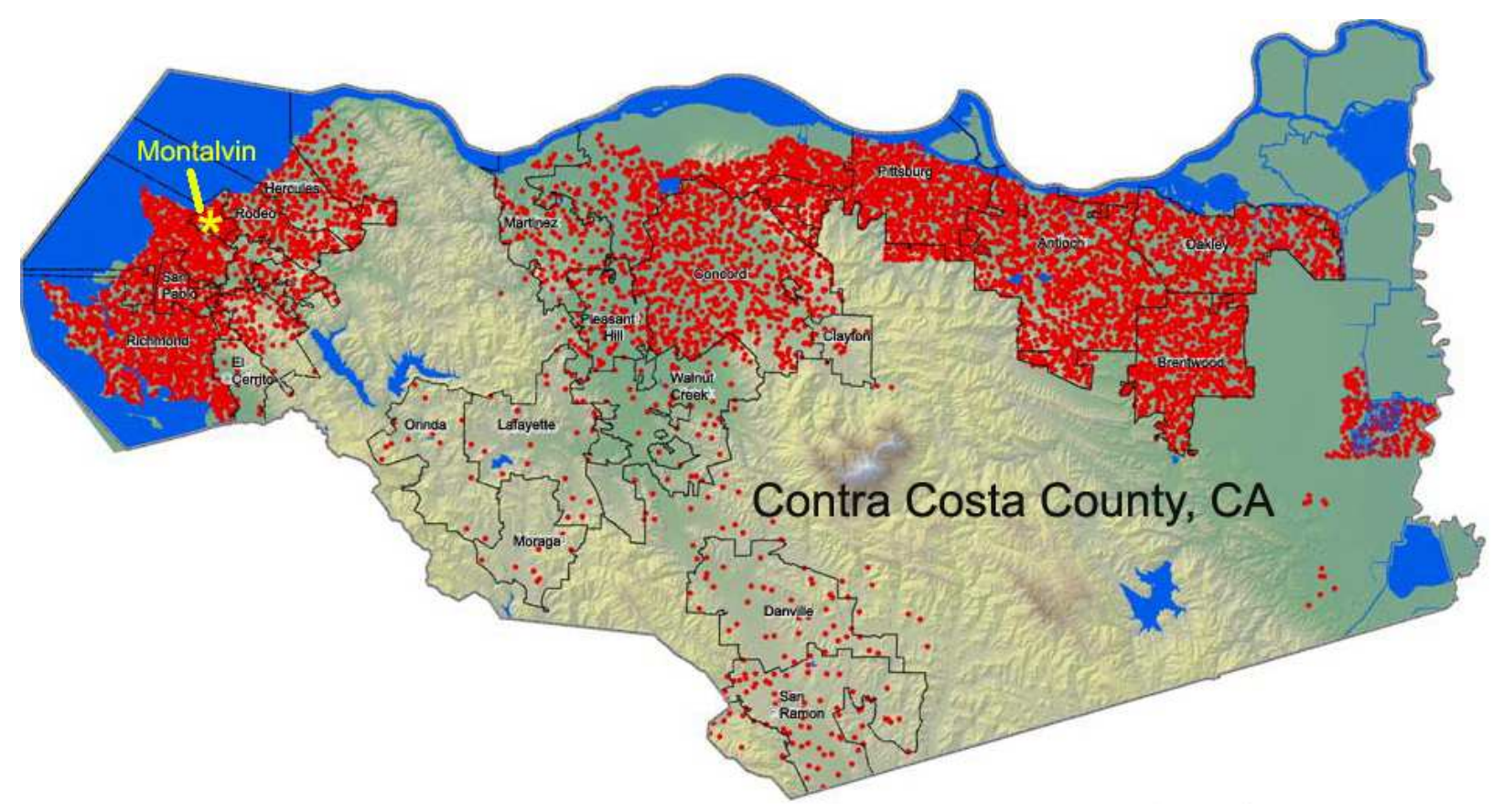

Figure 3.2 : Foreclosures in 2008 in Contra Costa County. (Incorporated cities are outlined). Source: Contra Costa County, 2009.

Figure 3.2 depicts county borders, marks the city limits of incorporated cities within its boundaries, and displays where foreclosures occurred (one red dot indicates one foreclosure). The concentration of red indicates high foreclosure concentrations occurred in the north and the west. These areas include the unincorporated communities of BayviewMontalvin Manor, Bay Point, North Richmond, and Rodeo. Predatory lending was widespread in these communities, and nearly one out of every ten homes was hit by the foreclosure crisis that began in 2007 (CCC, 2009). A significant number of the homes in these communities are over thirty years old and are in need of serious repairs, further contributing to the poor physical condition of the neighborhoods. 


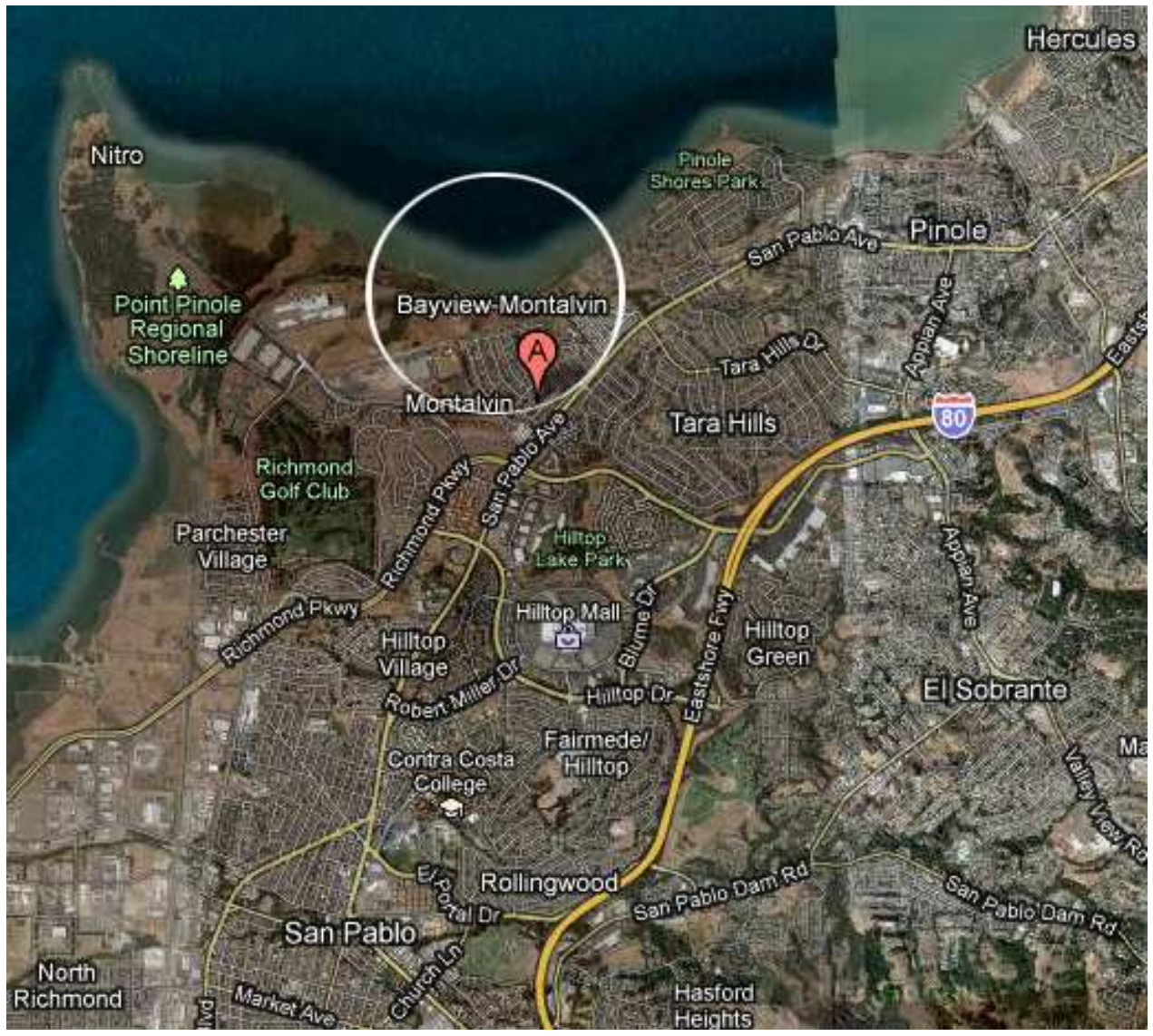

Figure 3.3 : Aerial map of Bayview-Montalvin Manor neighborhood in unincorporated Contra Costa County. Source: Google, 2010.

\section{Montalvin Manor Background}

The Bayview-Montalvin Manor neighborhood (hereon "Montalvin") is an unincorporated suburban Contra Costa County community on San Pablo Bay. Figures

3.1 and 3.2 indicate the community's location and proximity to other cities in western Contra Costa County. Montalvin is located approximately four miles north of the city of Richmond, one mile north of Interstate 80, and is sited immediately north of San Pablo Avenue, a main thoroughfare that connects to Oakland. Montalvin is a part of a Census Designated Place, identified by Census Tract number 3640.01 (Douglas, K., personal communication, June 162010 ). According to the 2000 Census 5,144 people lived in the Census track that includes Montalvin, with an average household size of 3.42 people 
(4.82 for Hispanic households), as shown in Table 3.1. Other Census findings relevant to this project are that the majority (89\%) of households used natural gas for heating, and median home price asked in year 2000 was $\$ 162,000$ (US Census, n.d.).

Table 3.1. Census Tract 3640.01 population data for 2000

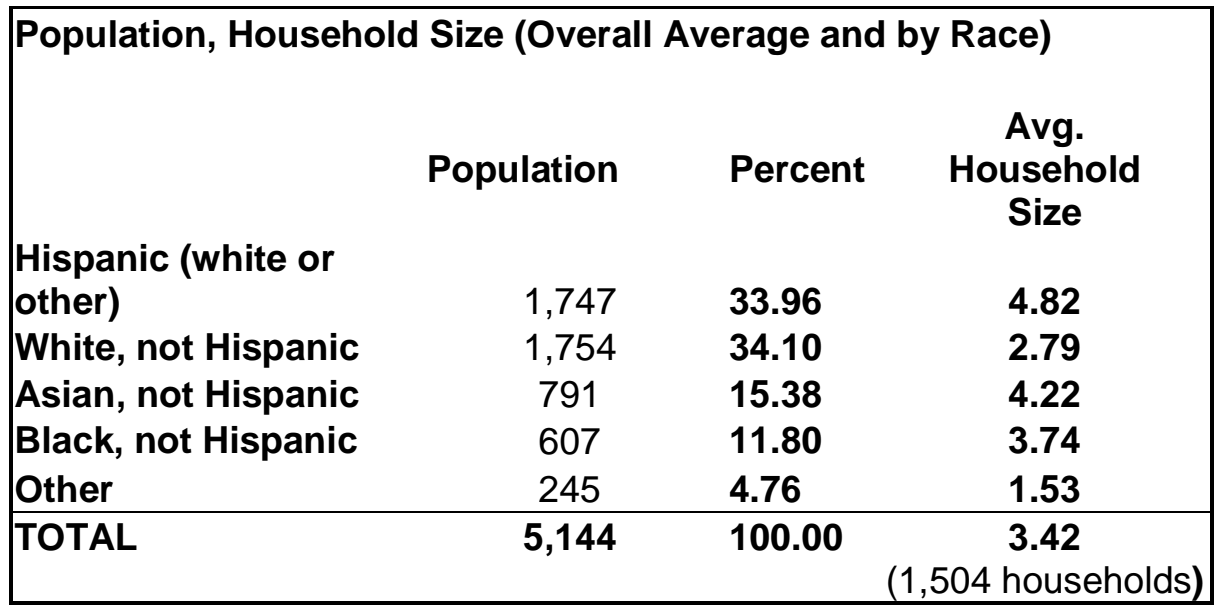

Source: Census Bureau, n.d.

A 2007 study undertaken by Gabriel Lemus and assistant Ryan Aguilar of Contra Costa County collected detailed information about the homes in the Montalvin neighborhood. The research found that the neighborhood consisted of 638 homes on 168 acres, most of which were built between 1952 and 1953. To find typical home size, homes were grouped into three categories by interior floor space size; plotting the home sizes produces the distribution show in Figure 3.4. Using the midpoints for the aggregated data, I estimated the average house size to be 1,113 square feet. Lemus and Aguilar also looked into the typical number of bedrooms. A distribution of the number of bedrooms (Figure3.5) shows that majority (61\%) have three bedrooms, some which were converted garages. 


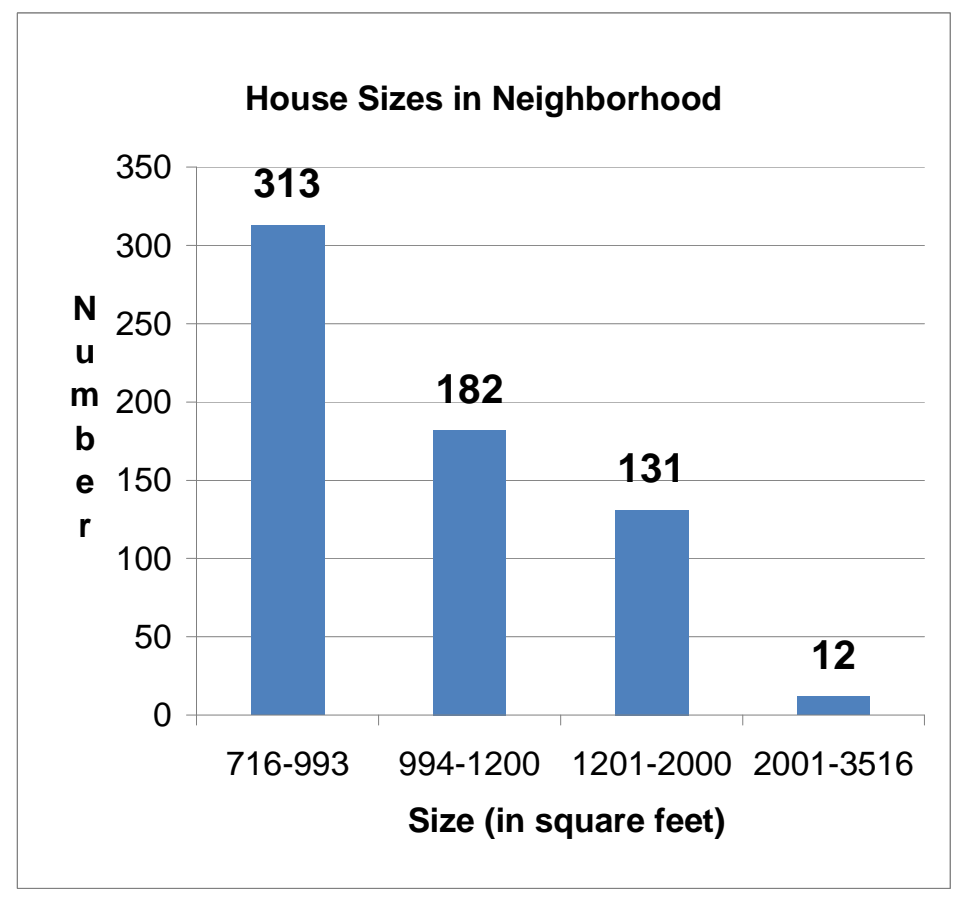

Figure 3.4 House Size Distribution in Montalvin. Based on data from Lemus 2007.

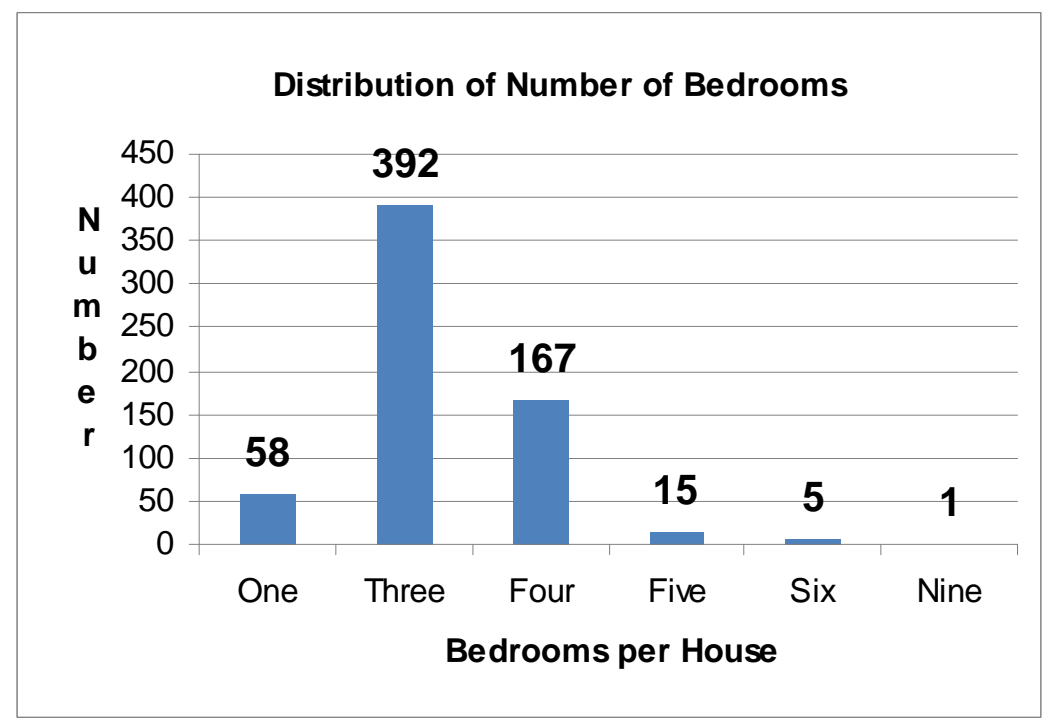

Figure 3.5. Number of bedrooms per home, distribution in Montalvin. Based on data from Lemus 2007. 
Lemus also confirmed the following were true of the typical Montalvin home features/construction:

- Single story construction, limited variety of floor plans throughout neighborhood

- No ceiling or wall insulation

- One or two bathrooms (1.5 used to represent average)

- Dishwasher 


\section{Chapter 3.0 - Methods}

This study estimates the costs and benefits of modifying an older, modest-sized home with two sets of green modifications: the original upgrades specified in Contra Costa County's NSP2 application, and an alternative set devised in the course of this project which also met the NSP2 program criteria. The method of evaluation consists of:

1) creating a home model representing the typical home in an eligible neighborhood

2) obtaining price quotes for labor and materials consistent with:

a) the original upgrades in the NSP2 proposal

b) the alternative set of green upgrades

c) the conventional equivalents of the original upgrades

3) estimating savings of water and energy, converted to net present value dollars, and

4) comparing initial cost to annual utility savings to estimate payback time.

The cost and benefit figures provide a hypothetical case study analyzing the costeffectiveness of the two different upgrade approaches. Combined with findings in professional and academic literature, they provide the basis of a reflection on how the NSP2 program and Contra Costa County's proposal could have been improved, and the HUD decision to include a greening element in the second version of the NSP program.

\section{Eligible Neighborhoods}

The County nominated 25 unincorporated urban Census Tracts that qualified for the NSP2 funds (CCC, 2009, p. 38). These neighborhoods are located in the northern and western sides of the county, and include Bayview-Montalvin Manor, Bay Point, North Richmond, and Rodeo (adjacent to the better known cities of Antioch, Pittsburg, Pinole, and Richmond). The neighborhoods consist mostly of the modest-sized, older homes; on average $79 \%$ of the households in these Census Tracts are classified as low-income or moderate income (CCC, 2009, p. 38). To optimally estimate the costs and benefits of the 
greening component of the Contra Costa County NSP2 proposal, one would need to collect detailed information of the dimensions and construction of homes across all 25 Census Tracts for the purpose of obtaining quotes for materials and labor, as well as to run utility savings calculators (in addition to supplemental data from US Census on household sizes and National Weather Service information on local climate). Detailed information on homes was not readily available for all nominated neighborhoods; it was not feasible to retrieve original building records for homes from these neighborhoods as the County did not regularly retain permits when homes were built in the 1950s and 1960s. Any records that did exist were not readily accessible within a timeframe appropriate for this project (Brockbank, D. personal communication, August 20, 2009). Thus, the optimal method of investigation based on information on the homes in all 25 Census Tracts was not possible.

\section{Montalvin Data}

Information on home dimensions and construction was readily available, however, for the unincorporated neighborhood of Bayview-Montalvin Manor (hereafter "Montalvin") from a 2007 study by Gabriel Lemus, Senior Redevelopment Planner for the area, and assisted by Ryan Aguilar. Montalvin is located on the west side of the County near Richmond and San Pablo in Census Tract 3640.01. Montalvin was eligible and nominated for NSP2 funds. Lemus and Aguilar generously shared data, floor plans, and general knowledge of Montalvin, which included total square footage and number of bedrooms for every house in the neighborhood, as well as one set of highly detailed, computer-drawn floor plans. County planner Gabriel Lemus and building inspector Joe Hatfield were also able to answer questions on insulation, appliances, and foundation types, based on records and personal observations. In combination, the study data on home sizes, information from these two County personnel and the collection of floor plans lent themselves very well to estimating the costs and benefits of the NSP2 greening element for Montalvin. 
Montalvin is made up of single-family homes built in the 1950s near San Pablo,

California. According to Lemus, the homes had limited variety when originally built, with one floor plan per style (i.e., a one floor plan for three bedroom homes). As of 2009, the most common ( $61 \%$ of homes) style is a three-bedroom model, with a converted garage or carport serving as one bedroom (Lemus, 2007). One set of floor plans provided was detailed and computer illustrated, depicting a three bedroom, two full bath home, in which one bedroom was formerly the garage (see Figure 3.6) . 


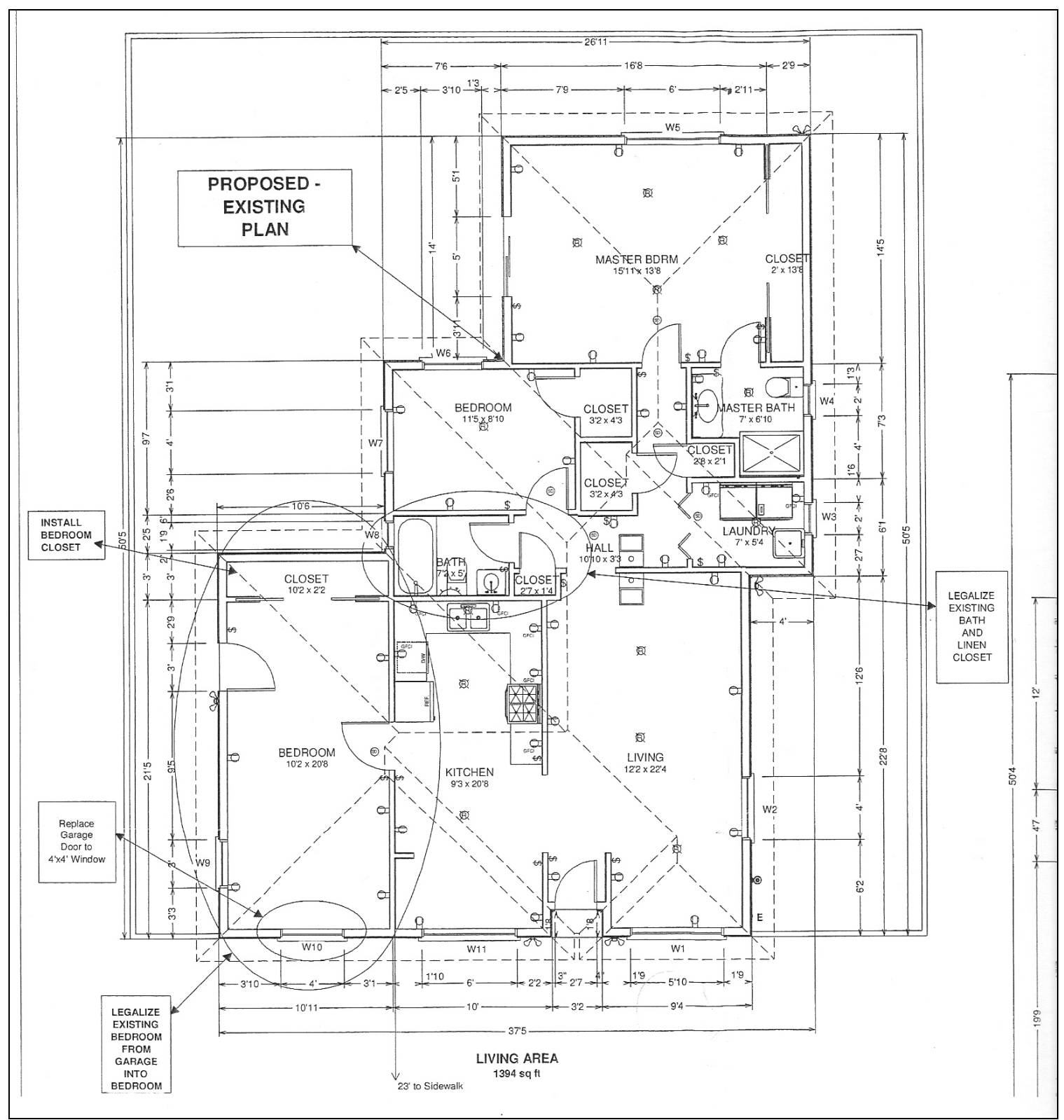

Figure 3.6 : Interior floor plan for Montalvin neighborhood home on Karen Road. Credit: Norma Jean Munoz.

The floor plans depict a home located on Karen Road in Montalvin, 1,394 square feet in total size, making it larger than the estimated average size of 1,113 square feet. The Karen Road home also has a second full bath, compared to an estimated average of one and a half bathrooms across all Montalvin homes. However, if modified by scaling the dimensions to $87 \%$ of original size, and eliminating the shower/tub from the second bathroom, this 
modified version of the Karen Road home has enough similarity to the average home in Montalvin to serve as a good representative for the typical home. According to architecture professor Tom Di Santo, scaling the rooms and windows in this manner is realistic and appropriate for this purpose (personal communication, April 8, 2010). The combination of the neighborhood's relative uniformity in floor plans, the availability of construction data from Lemus and Aguilar, and the detailed, readily scalable computer-drawn floor plan offered a suitable basis for creating a home model representing the average home in the Montalvin neighborhood. This home model could then be used to price the amount/sizes of green materials, and to solicit contractor labor quotes for installation. Thus, a hypothetical case study of the cost-effectiveness of the green component of Contra Costa County's NSP2 proposal could be built from a representative Montalvin home model. 


\section{Home Model}

A model was created based on the Montalvin neighborhood's average home dimensions, a scaled version of the detailed floor plan for the home on Karen Road, and from conversations with the Lemus fire fighters reports, and professor of architecture Di Santo (Lemus, 2007; CFBT-US, n.d.; Di Santo, D., personal communication, April 9, 2010). This home represents the average house in the neighborhood. The model was used to calculate the amounts and sizes of materials or products needed, and respectively the labor needed to green the home. The home model dimensions and characteristics as follows:

- 1,113 square feet total

- Windows and rooms scaled to $87 \%$ of Karen Road home dimensions

- Single story

- Flat roof of tar and gravel

- 8 foot tall ceilings

- 3 bedrooms (one is a converted garage)

- 1.5 bathrooms

- No insulation in the ceiling, no insulation in the walls

- Knob and tube electrical wiring

- Natural gas for water heater and for wall furnace

- Conventional appliances typical to modest homes (includes dishwasher)

- Carpet in bedrooms and living room, vinyl linoleum in bathroom and kitchen

\section{Typical Household}

Montalvin is in Census Tract 3406.01, and according to the 2000 Census, the median household size was 3.42 (Census, n.d.). Based on this fact, my representative household was three people. 


\section{Climate (Historical)}

Climate is another factor important to estimating energy savings, as well as in selecting the appropriate upgrades. Temperature regime helps predict how much people will likely use heating and cooling systems, which make up a significant portion of annual household energy bills. The closest NOAA (National Oceanic \& Atmospheric Administration) weather station is sited in Richmond, California, approximately 4 miles southwest of Montalvin (NOAA, 2004). NOAA provides a data set that reports temperature means and extremes for each of the twelve months, aggregated from the year 1971 to year 2000 (NOAA, 2004). Over the thirty-year period, the mean winter lows for the Richmond area was in the 40s (Fahrenheit) and summer highs was in the low 70s (see Figure 3.7 below). Extreme recorded events have pushed temperatures up to $107^{\circ} \mathrm{F}$ and down to $24^{\circ} \mathrm{F}$. Overall, Richmond has historically had mild weather, and occupants may be most comfortable with a building that retains heat year round, with some features to quickly dissipate extreme heat on the few severe weather days (i.e., windows and ceiling fans).

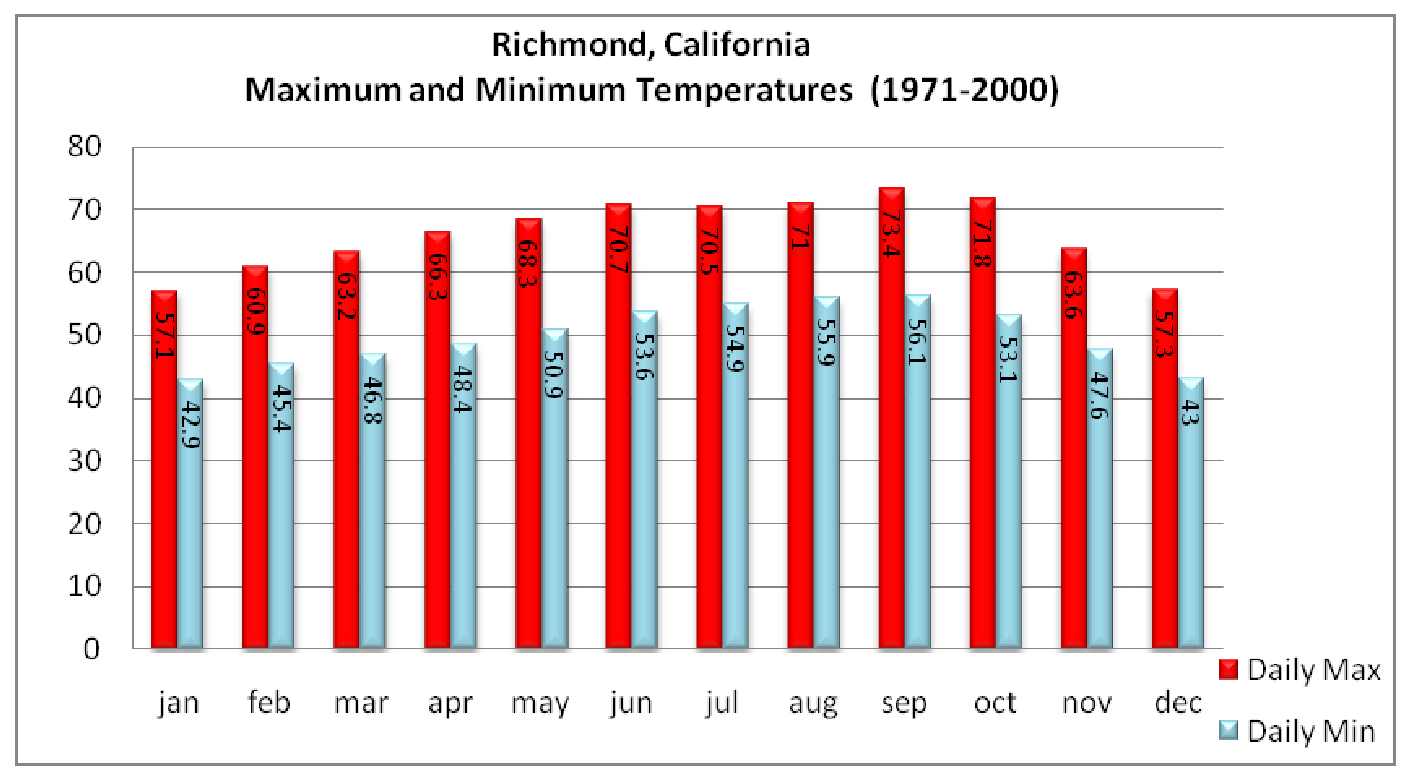

Figure 3.7 Historic Richmond Annual Temperature Regime (in Fahrenheit). Based on NOAA, 2004. 


\section{Chapter 4.0 - Original Green Upgrades}

Homes with green modifications perform better than unimproved homes, which contribute to their improved affordability and smaller environmental footprints. Greened homes also improve occupant health (Connelly 2006, USGBC 2007 as cited in Sparks, 2007). In the NSP2 affordable housing program, applicants were required to commit to greening homes. Specifically, HUD required jurisdictions to improve the water efficiency, energy efficiency, and indoor air quality of foreclosed homes they would purchase, repair, and offer as affordable housing (HUD, 2009a, p. 14, 82). In this section, the original green upgrades set (proposed in the County's NSP2 application) are listed then interpreted and applied to the home model. Cost estimates for labor and materials to execute the original set of green upgrades are presented, and to estimate a "green premium" (a higher initial cost for green products and associated installation), an additional set of upgrades comparable to the original upgrades but conventional (not water or energy efficient) were also cost estimated for materials and labor.

\section{Original Green Upgrades}

At the time the original green upgrades set was developed, no professional greening guides, upgrade checklists, or academic papers were identified to serve as a suitable stand-alone guide for the County the small budget and scope of the County. The Enterprise Green Communities guide (which HUD recommended), and the GreenPoint Ratings guide (which the County ultimately referenced), and HUD's funding notification itself were found insufficient. These guides recommended major upgrades that were perceived as inappropriate or too expensive (rightly or wrongly) such wall insulation, changing building orientation, green roofing, or solar panels (Enterprise, 2008; BuildltGreen, 2007; HUD, 2009a, p. 80). Further, none of these guides provided pricing guidance. Due to the short time timeframe in which the application was prepared (June 
12, 2009 to July 15, 2009) and lack of robust guidance, County planners selected perceived low-cost upgrades from the three sources (Enterprise, BuilditGreen, and HUD) to formulate the original upgrades list, using best personal judgment and experience in estimating costs for similar upgrades to green their own residences. Without time for formal cost estimation, County planners used best personal judgment to allocate a budget of $\$ 15,000$ per house, intended to cover labor and materials to implement the green upgrades. Though the County identified the GreenPoint Existing Home Rating System as the rating system it would follow, the upgrade list the County committed itself to was mostly based on upgrades mentioned in the funding notification from HUD (CCC, 2009; p 4, HUD, 2009a, p14, 28-29, 80-83). The County committed to upgrading seven features of all units, which are reproduced here, verbatim from the application (Figure 4.1).

1. Replace conventional faucets, showerheads, and toilets with water-saving/low-flow components.

2. Paint surfaces with low volatile organic compound (low VOC) paints.

3. Install Energy Star rated appliances.

4. Install Energy Star qualified light fixtures with energy efficient light bulbs.

5. Replace standard windows with low-emissivity, double paned windows.

6. Install low-VOC carpet or renewable bamboo.

7. Properly seal openings to the outside with weather stripping and pest barriers.

Figure 4.1 Original green upgrades commitment from Contra Costa County NSP2 application. Source: CCC, 2009 , p34.

As shown in Figure 4.1, the upgrades primarily consisted of replacing existing items with Energy Star or WaterSense labeled products. Energy Star is a joint program of the US Environmental Protection Agency (EPA) and US Department of Energy (DoE). The Energy Star label signifies an appliance is more energy efficient compared to 
conventional versions (Energy Star, n.d.a). WaterSense is a program of the US EPA. WaterSense label ensures water efficiency and performance to EPA standards, verified by third-party certifiers (EPA, 2010c). Low VOC paints and low VOC carpet were intended to improve indoor air quality, while double paned windows and weatherstripped doors were intended to improve warmth retention in winter and coolness retention in summer.

\section{Original Materials Selection Overview}

Each broad upgrade commitment from the application (Figure 4.1) was converted into green and conventional versions, appropriately sized for the home model created for this study (see Chapter 3). Alongside this, the equivalent conventional version was selected and price for materials and labor. Appendix A1 presents the details of the green and conventional material items selected to implement the upgrades: the model, brand, amount or size, retailer item number, along with item-by-item material costs and labor cost quotes from a respected local contractor. (Note that details for labor cost procurement are at the end of the chapter, following the materials selection sections.) For each original upgrade measure, this chapter provides material selection rationale, general product descriptions, and a table with the combined material and labor costs for each measure, in both a green and conventional of each. Material selection rationale includes a description of how the measure relates improving air quality, or water and/or energy efficiency. Most material selection had two components: amount or size, and model and brand. Method of calculation for sizing or amount of products varied accordingly with the model home feature under study, as described in the appropriate section. Most materials were cost estimated at major home improvement retailer Home Depot through their website or during trips made in person. The exception is a cost quote for the green (zero VOC) paint from Kelly-Moore (sold only from their stores) that was obtained by phone. The brand and model selected for each upgrade in green and 
conventional versions were "economy" models; that is, the cost and item number of the lowest-priced item available was recorded, unless it received a significant number of negative customer comments (more than a third of posted comments) on the website. In these instances, a slightly more expensive model was selected with fewer negative comments. Finally, the full price (not sales price) was recorded.

Two other considerations should be kept in mind related to material costs. First, Energy Star offers a bulk purchasing program which could potentially bring prices down further for certain items, but this avenue was not explored since bulk purchase was not mentioned by the planners or in the HUD funding notice, and this study was more interested in the cost difference between conventional and green equivalents, either of which could feasibly be purchased in bulk. Second, like many government-funded projects, NSP2 originally had a "Buy American" clause that strongly promotes purchase of American-made products in public structures. NSP2 homes would be subject to the clause, as they are considered "a residential structure owned by a governmental entity" (HUD, 2009b). However, HUD issued a waiver in October 2009 that excluded property with less than eight units, and this seems to have included single-family homes repaired through NSP2 (HUD, 2009b). The only item in this study that was known to be made in America was the Kelly-Moore zero-VOC paint. 


\section{Appliances}

Table 4.1 Costs for green and conventional models of household appliances.

\begin{tabular}{|c|c|l|c|}
\hline $\begin{array}{c}\text { Appliance - Clothes } \\
\text { Washer }\end{array}$ & Conv. & $\begin{array}{l}\text { Economy model, over } \\
3 \text { cubic feet }\end{array}$ & $\$ 559.00$ \\
\cline { 2 - 4 } & Green & $\begin{array}{l}\text { EnergyStar rated } \\
\text { economy model, over } \\
3 \text { cubic feet }\end{array}$ & $\$ 848.00$ \\
\hline \multirow{2}{*}{$\begin{array}{c}\text { Appliance - } \\
\text { Dishwasher }\end{array}$} & Conv. & Economy model & $\$ 669.00$ \\
\cline { 2 - 4 } & Green & $\begin{array}{l}\text { EnergyStar rated } \\
\text { economy, water } \\
\text { efficient model }\end{array}$ & $\$ 849.00$ \\
\hline $\begin{array}{c}\text { Appliance - } \\
\text { Refrigerator }\end{array}$ & Conv. & $\begin{array}{l}\text { Economy model, over } \\
\text { 25 cubic sq. feet }\end{array}$ & $\$ 959.00$ \\
\cline { 2 - 4 } & Green & $\begin{array}{l}\text { EnergyStar rated, } \\
\text { over 25 cubic sq. } \\
\text { feet, economy model }\end{array}$ & $\$ 859.00$ \\
\hline
\end{tabular}

Appliances account for two-thirds of the electricity used in American homes (DoE 1999 as cited in Sparks, 2007). Replacement of conventional appliances with Energy Star rated appliances was specifically mentioned in the HUD funding notice as a measure that satisfies the green component of the NSP2 proposal (HUD, 2009a, p.14). According to the categorization of products on the Energy Star website, the category "appliances" specifically includes clothes washers, dishwashers, refrigerator/freezers, dehumidifier/air purifiers, and water coolers. The last two items seemed to be non-essential household appliances, and were thus omitted. Cost estimates were made for the three household appliances in both a conventional economy model and an Energy Star rated economy model. The capacity or power of the item was appropriate to the model home dimensions or household size, per government or retailer guides for size selection. Specifically, the refrigerator's size was based on recommendations from Home Depot, dishwasher size was identical to the original appliance in the Karen Road home kitchen (see page 16), and the clothes washer was "full size" (appropriate for a family) with at least 3.1 cubic feet capacity (Best Buy, 2007; Home Depot, 2010). 


\section{Flooring and Paint}

Table 4.2 Costs for green and conventional models of flooring and paint.

\begin{tabular}{||c|c|c|}
\hline \multirow{2}{*}{ Flooring } & Conv. & $\$ 3,375.12$ \\
\cline { 2 - 3 } & Green & $\$ 5,672.24$ \\
\hline \multirow{2}{*}{ Paint } & Conv. & $\$ 3,115.72$ \\
\cline { 2 - 3 } & Green & $\$ 3,202.04$ \\
\hline
\end{tabular}

According to the United States Center for Disease Control, low-income people endure the highest rates of asthma, with many known and suspected triggers linked to conditions in the home (ECP 2007 as cited in Sparks, 2007). Using certain types of paint and flooring can reduce asthma triggers from poor indoor air quality. Carpet attracts allergens, but conventional laminate flooring is made of plastic (petroleum) and thus is unsustainable. A suitable replacement is bamboo (which is natural and renewable). Found in paint, volatile organic compounds (VOCs) are associated with asthma and the elderly, those with weak immune systems, and young children are most prone to the effects of VOCs (Global Green 2006, as cited in Sparks, 2007, p. 71). A green choice is zero or low-VOC paint. To determine the amount of paint and flooring needed, the surface area of the interior of the home model (see page 16) was calculated. Square footage was already estimated during the home model design phase. Ceiling height was assumed to be eight feet, based on ceiling height of another home in the neighborhood, and eight feet is also considered a height typical for modest homes (CBFT-US, n.d.; Di Santo, T. personal communication, April $7,2010)$. Paint was calculated to be sufficient to cover all surfaces, including the ceilings and insides of closets; the assumption was made that one gallon covers 350 square feet of surface, a common rule of thumb (Kimbell, R., personal communication March 22, 2010). Flooring amount was calculated to be sufficient to cover all rooms, plus $10 \%$ extra to allow 
for mistakes in cutting tiles for edges and corners, per industry recommendation (efloors.com, n.d.). Low and zero VOC paint (the "green version" of paint) was difficult to find at major retailers. Ultimately Kelly-Moore Green Coat, a zero VOC paint, was selected because it is a relatively inexpensive zero VOC paint and Kelly-Moore is a Bay Area-based company with a store located four miles from the project site, thus it seemed to be the most appropriate choice for the project. Additionally, speaking with the contractor who provides lead based paint safety services, a minimum of $\$ 600$ to test and certify that the home is lead free due to federal regulations effective April 2010 (Baxter, N. personal communication May $27,2010)$. This cost was included in my calculations, as it would be incurred whether or not green or conventional paint were being used, and even if lead testing was negative. If lead test were positive, painting costs were quoted to increase from $\$ 900-\$ 1,500$ for removal before painting could be done. The green flooring selected was the economy model of bamboo, a quickly renewing wood alternative to hardwood flooring carried by Home Depot. The conventional version of paint was the cheapest on the Home Depot website, and the conventional flooring was the economy model laminate, as detailed in Appendix A1. 


\section{Lights and Bathroom Fan with Built in Light}

Table 4.3 Costs for green and conventional models of lights and lights with fans.

\begin{tabular}{|c|l|l|l|}
\hline \multirow{2}{*}{$\begin{array}{c}\text { Lights and Fan for } \\
\text { Bathroom }\end{array}$} & Conv. & Economy model & $\$ 821.00$ \\
\cline { 2 - 4 } & Green & $\begin{array}{l}\text { EnergyStar rated } \\
\text { economy model }\end{array}$ & $\$ 1,244.00$ \\
\hline \multirow{2}{*}{$\begin{array}{c}\text { Lighting for Other } \\
\text { Rooms }\end{array}$} & Conv. & $\begin{array}{l}\text { Economy single bulb } \\
\text { fixtures and motion } \\
\text { sensor lights }\end{array}$ & $\$ 1,646.93$ \\
\cline { 2 - 4 } & Green & $\begin{array}{l}\text { EnergyStar rated } \\
\text { economy single bulb } \\
\text { fixtures and motion } \\
\text { sensor lights }\end{array}$ & $\$ 2,244.35$ \\
\hline
\end{tabular}

Energy Star qualified lighting uses two-thirds less energy and lasts six to ten times longer than traditional lighting, resulting in reduced energy use, lower utility costs, and lower greenhouse gas emissions (ECP 2007, NAHB 2006 as cited in Sparks 2007). Compact fluorescent light bulbs (CFLs) use two-thirds less energy than a standard incandescent bulb and must meet additional operating and reliability guidelines (Doxley, 2006 as cited in Sparks, 2007). Cost estimates are provided for four types of light fixtures, in green and conventional version economy models. These are as follows. 1) Motion detectors. No Energy Star motion detector lights were found, so both green and conventional cost estimates used the same model motion detectors. Labor costs were procured for installation of 4 (instead of 5) motion detectors; to correct for this error, the installation cost was increased by $25 \%$.

2) Bathroom bar-style fixtures. These are horizontal fixtures with multiple bulbs designed for bathrooms. Two were cost estimated, one for each of the two bathrooms. The conventional barstyle bath light did not include light bulbs, so appropriately sized standard economy bulbs were priced for the conventional model. 3) Bathroom overhead fans with built-in lights. The green version was selected by cross-referencing the qualified fixtures listed on the Energy Star website with low cost models available at major retailers. The conventional model was the 
comparable, modestly priced model. Labor quotes were procured without inaccuracies. 4) Single-bulb fixtures. Floor plans for the Karen Road home indicate 10 existing standard single-bulb overhead light fixtures for the living spaces and laundry room. The laundry room light fixture was omitted from upgrades, as it was assumed this light is seldom used. The green single-bulb fixture selected was an economical Energy Star rated fixture that included bulbs, while the conventional version was similarly economical but required additional purchase of corresponding economy bulbs. In both green and conventional upgrade schemes, the converted garage bedroom was wired for an overhead single bulb. The labor quote for conventional upgrades to single-bulb fixtures was incorrectly procured-replacement of eight standard fixtures (instead of nine) was priced, which also included the costs for wiring one room. To conservatively correct for this error, one-eighth of the labor quote has been added in labor column for lighting upgrades in the summary sheet, Appendix A1. For details on the three lighting configurations cost estimated for this study, see Appendix B. 


\section{Water Fixtures}

Table 4.4 Costs for green and conventional models of water fixtures.

\begin{tabular}{|c|l|l|l|}
\hline $\begin{array}{c}\text { Water Fixture - Bath } \\
\text { Faucets }\end{array}$ & Conv. & Economy faucet model & $\$ 196.00$ \\
\cline { 2 - 4 } & Green & WaterSense low-flow & $\$ 516.00$ \\
\hline $\begin{array}{c}\text { Water Fixture - } \\
\text { Kitchen Faucet }\end{array}$ & Conv. & Economy faucet model & $\$ 150.00$ \\
\cline { 2 - 4 } & Green & $\begin{array}{l}\text { Conventional economy } \\
\text { model plus aerator }\end{array}$ & $\$ 186.00$ \\
\hline $\begin{array}{c}\text { Water Fixture - } \\
\text { Showerhead }\end{array}$ & Green & WaterSense low-flow & $\$ 87.87$ \\
\cline { 2 - 4 } & Conv. & Standard, Single flush & $\$ 537.00$ \\
\hline $\begin{array}{c}\text { Water Fixture - } \\
\text { Toilets }\end{array}$ & Green & $\begin{array}{l}\text { WaterSense, Dual } \\
\text { flush }\end{array}$ & $\$ 586.00$ \\
\hline
\end{tabular}

Sixty percent of urban water use is residential, and improving water efficiency means a greater number of households can be served with existing water supplies. In cases where surface water is used, such as in the Bay Area, increased water efficiency can also mean decelerated competition for water with wildlife. (While indoor water fixtures were addressed, outdoor water fixtures were omitted from the County upgrades as an upfront cost minimization strategy.) Showerheads and faucets account for approximately $25 \%$ of indoor water use, while toilets account for approximately 24\% (Ogorzalek 2003, USGBC 2007 as cited in Sparks 2007). In their NSP2 proposal, the County committed to replacing existing indoor water fixtures with WaterSense labeled fixtures. WaterSense is a program of the US EPA that recognizes products that enhance water efficiency and perform well, surpassing maximum flow rate standards set by the federal government (EPA, 2010c). Table 4.5 compares federal maximum flow rate standards with the stricter WaterSense standards, as well as showing the flow rates possible with the free water fixture devices offered by EBMUD (East Bay Municipal Utility District), a Bay Area water supplier, which supplies the subject neighborhood. Most free modification devices would effectively reduce flow rate to meet federal standards, but the free toilet modification device would not have met federal standards. 
Table 4.5 Comparison of water flow rates standards for devices, in gallons per minute.

\begin{tabular}{|l|l|l|l|}
\hline FIXTURE & $\begin{array}{l}\text { Federal } \\
\text { Requirement }\end{array}$ & $\begin{array}{l}\text { WaterSense } \\
\text { Standard }\end{array}$ & $\begin{array}{l}\text { EBMUD } \\
\text { Free Device }\end{array}$ \\
\hline Toilet & 1.6 & 1.28 & 2.7 \\
\hline Bath Faucet & 2.2 & 1.5 & 1.0 \\
\hline $\begin{array}{l}\text { Kitchen } \\
\text { Faucet }\end{array}$ & 2.5 & N/A & 1.5 \\
\hline Showerhead & 2.5 & 2.0 & 2.5 \\
\hline
\end{tabular}

Sources: EPA 2008; EPA 2010c; EBMUD 2010.

To cost estimate the green version of upgrade products, the price and item number of the most economical WaterSense labeled fixtures found at Home Depot were recorded. For the conventional versions, the lowest cost economy fixtures not labeled with the WaterSense label were recorded (which by default met federal standards). However, since the EPA does not include kitchen faucets in the WaterSense program as of 2010, the best representation of the commitment to a new green kitchen faucet would be combining the new conventional economy model faucet with an aerator, as cost estimated in Table 4.4. Also, the green (lowflow) showerhead selected was not the least expensive green model, as the absolute least expensive WaterSense model appeared quite flimsy. A more robust item would more likely be selected by the County staff, as there was a small price increase for a seemingly more durable product.

It should be noted that the County could have met its water-saving goals, alternatively, by modifying existing fixtures with water saving devices. The third column of Table 4.5 shows the typical flow rates of existing fixtures when modified with water saving devices provided free as of 2010 by EBMUD, Montalvin's water supplier. While the County seemingly obligated itself to fixture replacement in its original proposal, homes in Montalvin and other areas serviced by utility provider EBMUD are eligible for free water saving devices (maximum two each), including toilet tank displacement bags, low-flow showerhead, and 
kitchen and bath faucet aerators. The upfront material cost would have been significantly cheaper than paying for new fixtures. Although EBMUD typically only provides these items to customers able to present a utility bill, a senior customer service representative stated by email (EBMUD, personal communication, March 24, 2009) that a County employee bearing identification could pick up the devices if they provide documentation showing County's ownership of a home in EBMUD territory, and proof of rehabilitation (perhaps for instance, contractor estimates with the home address).

Weatherstripping

Table 4.6 Costs for Weatherstripping

\begin{tabular}{||c|c|l|c|}
\hline \multirow{2}{*}{ Weatherstripping } & Conv. & none (no equivalent) & $\$ 0.00$ \\
\cline { 2 - 4 } & Green & $\begin{array}{l}\text { Door sweeps and } \\
\text { silicon tubing }\end{array}$ & $\$ 110.72$ \\
\hline
\end{tabular}

Weatherstripping is the addition of flexible material to the edges of windows and doors to reduce drafts of air between the home and the outside but still allow for easy opening and closing. Typically, this consists of adhering rubber or foam strips to the threshold of the door or as a metal door sweep, or small gaps between the window and sill. Weatherstripping can "significantly" reduce heating and cooling costs, improve building durability, and create a healthier indoor environment, and pays for itself in one year (DoE 2001, DoE 2009a). The Karen Road home has two doors that open to outside and would be candidates for weatherstripping. The door sweeps and rubber material selected were economy models that appeared durable, and were ordered according to the $5-10 \%$ extra rule of thumb (DoE, 2001). 


\section{Windows}

Table 4.7 Costs for green and conventional models of windows.

\begin{tabular}{|c|c|l|c|}
\hline \multirow{2}{*}{ Windows } & Conv. & $\begin{array}{l}\text { Single paned vinyl } \\
\text { frame }\end{array}$ & $\$ 7,588.13$ \\
\cline { 2 - 4 } & Green & $\begin{array}{l}\text { Dual paned, low } \\
\text { emissivity }\end{array}$ & $\$ 7,975.50$ \\
\hline
\end{tabular}

According to the Department of Energy, when single paned windows are replaced with Energy Star qualified windows, energy costs are estimated to fall by $\$ 124$ dollars a year (in 2009 dollars), or generally up to 15\% (Energy Efficiency Partnership [EEP], 2010a). The Karen Road floor plans provided a list of window sizes. These were scaled down to $87 \%$ of original size for the home model, with the exception of three windows that had to be slightly larger than scale to be adequate for fire egress (Bray, S., personal communication, March 23, 2010). The dimensions were treated as the window openings for replacement windows. Per the recommendation of architecture Professor Di Santo, Milgard brand dual pane low emissivity windows were selected for the green version; the Style Line model was the most economical model that met these specifications and was accordingly used. The most economical conventional (single pane) replacement windows were from manufacturer JeldWen, specifically the single paned 600 Series model. Specific model recommendations for both green and conventional windows were made by The Home Depot window specialist (Home Depot, personal communication, March 24, 2010).

An error was made in window size calculations. Window price quotes were made using a set of dimensions for windows that were not scaled precisely to $87 \%$. The errors were mostly less than five inches on width or height, but two windows were short by 13 inches in height. The correct calculations are supplied in (Appendix B). Since both single and dual pane windows price quotes were made using the same dimensions, the assumption was made that the cost difference between the single and dual pane windows obtained with the incorrect dimensions also represents the price difference between correctly scaled single and dual pane windows. 


\section{Labor Quotes}

Two contractors, which previously worked for the County on home repair or rehabilitation projects, were asked to submit labor quotes. Though both Contractors responded to phone calls and indicated willingness to participate, only one actually followed through and returned a full estimate, and even provided a breakdown of anticipated hours of labor in addition to line-by-line cost estimates. This was Hodges Construction, which is based in Concord, CA. Since the labor estimates were not statistically sampled, they are intended serve two purposes:1) to provide a rough "ballpark" estimate of what the labor for upgrades cost, 2) to provide an estimate of the cost difference between the green and conventional upgrades. The request for estimates packet included a cover letter openly stating that the estimates were for my master's project, provided a description of the model home, and two spreadsheets for the conventional and green upgrades, named "Estimate 1" and "Estimate 2," respectively (see Appendix C1 and C2 for these materials). The spreadsheets distinctly categorized the upgrade types (water fixtures, lighting, appliance replacements, etc.) and provided the Home Depot item numbers for easy reference. The reader will see that the quotes included work beyond the scope of Contra Costa County's NSP2 application, to assist with a later part of this analysis. Any errors in the quote procurement spreadsheet and measures to compensate or correct are described in the appropriate material description sections. 


\section{Chapter 5.0 - Findings for Original Green Upgrades}

Cost

Table 5.1. Summary of Original Green Upgrade Costs, with Conventional Equivalents

\begin{tabular}{|c|c|c|c|c|c|}
\hline ITEMS & Version & $\begin{array}{l}\text { Cost } \\
L+M\end{array}$ & $\begin{array}{l}\text { Cost - } \\
\text { Material }\end{array}$ & Cost - Labor & $\begin{array}{l}\text { Green - Conv. } \\
\text { Difference }\end{array}$ \\
\hline \multirow{2}{*}{$\begin{array}{c}\text { Appliance - Clothes } \\
\text { Washer }\end{array}$} & Conv. & $\$ 559.00$ & $\$ 359.00$ & $\$ 200.00$ & \multirow{2}{*}{$\$ 289.00$} \\
\hline & Green & $\$ 848.00$ & $\$ 448.00$ & $\$ 400.00$ & \\
\hline \multirow{2}{*}{$\begin{array}{l}\text { Appliance - } \\
\text { Dishwasher }\end{array}$} & Conv. & $\$ 669.00$ & $\$ 219.00$ & $\$ 450.00$ & \multirow{2}{*}{$\$ 180.00$} \\
\hline & Green & $\$ 849.00$ & $\$ 399.00$ & $\$ 450.00$ & \\
\hline \multirow{2}{*}{$\begin{array}{l}\text { Appliance - } \\
\text { Refrigerator }\end{array}$} & Conv. & $\$ 959.00$ & $\$ 899.00$ & $\$ 60.00$ & \multirow{2}{*}{$-\$ 100.00$} \\
\hline & Green & $\$ 859.00$ & $\$ 799.00$ & $\$ 60.00$ & \\
\hline \multirow{2}{*}{ Flooring } & Conv. & $\$ 3,375.12$ & $\$ 1,225.12$ & $\$ 2,150.00$ & \multirow{2}{*}{$\$ 2,297.12$} \\
\hline & Green & $\$ 5,672.24$ & $\$ 3,672.24$ & $\$ 2,000.00$ & \\
\hline \multirow{2}{*}{$\begin{array}{c}\text { Lights and Fan for } \\
\text { Bathroom }\end{array}$} & Conv. & $\$ 821.00$ & $\$ 176.00$ & $\$ 645.00$ & \multirow{2}{*}{$\$ 423.00$} \\
\hline & Green & $\$ 1,244.00$ & $\$ 344.00$ & $\$ 900.00$ & \\
\hline \multirow{2}{*}{$\begin{array}{l}\text { Lighting for Other } \\
\text { Rooms and } \\
\text { Outdoors }\end{array}$} & Conv. & $\$ 1,646.93$ & $\$ 194.43$ & $\$ 1,452.50$ & \multirow{2}{*}{$\$ 717.42$} \\
\hline & Green & $\$ 2,364.35$ & $\$ 251.85$ & $\$ 2,112.50$ & \\
\hline \multirow{2}{*}{ Paint } & Conv. & $\$ 3,115.72$ & $\$ 265.72$ & $\$ 2,850.00$ & \multirow{2}{*}{$\$ 86.32$} \\
\hline & Green & $\$ 3,202.04$ & $\$ 352.04$ & $\$ 2,850.00$ & \\
\hline \multirow{2}{*}{$\begin{array}{l}\text { Water Fixture - Bath } \\
\text { Faucets }\end{array}$} & Conv. & $\$ 196.00$ & $\$ 46.00$ & $\$ 150.00$ & \multirow{2}{*}{$\$ 320.00$} \\
\hline & Green & $\$ 516.00$ & $\$ 116.00$ & $\$ 400.00$ & \\
\hline \multirow{2}{*}{$\begin{array}{l}\text { Water Fixture - } \\
\text { Kitchen Faucet }\end{array}$} & Conv. & $\$ 150.00$ & $\$ 30.00$ & $\$ 120.00$ & \multirow{2}{*}{$\$ 36.00$} \\
\hline & Green & $\$ 186.00$ & $\$ 36.00$ & $\$ 150.00$ & \\
\hline \multirow{2}{*}{$\begin{array}{l}\text { Water Fixture - } \\
\text { Showerhead }\end{array}$} & Conv. & $\$ 54.85$ & $\$ 4.85$ & $\$ 50.00$ & \multirow{2}{*}{$\$ 33.02$} \\
\hline & Green & $\$ 87.87$ & $\$ 12.87$ & $\$ 75.00$ & \\
\hline \multirow{2}{*}{$\begin{array}{l}\text { Water Fixture - } \\
\text { Toilets }\end{array}$} & Conv. & $\$ 537.00$ & $\$ 187.00$ & $\$ 350.00$ & \multirow{2}{*}{$\$ 49.00$} \\
\hline & Green & $\$ 586.00$ & $\$ 236.00$ & $\$ 350.00$ & \\
\hline \multirow{2}{*}{ Weatherstripping } & Conv. & $\$ 0.00$ & & & \multirow{2}{*}{0} \\
\hline & Green & $\$ 110.72$ & $\$ 35.72$ & $\$ 75.00$ & \\
\hline \multirow{2}{*}{ Windows } & Conv. & $\$ 7,588.13$ & $\$ 2,188.13$ & $\$ 5,400.00$ & \multirow{2}{*}{$\$ 387.37$} \\
\hline & Green & $\$ 7,975.50$ & $\$ 2,775.50$ & $\$ 5,200.00$ & \\
\hline TOTAL & Conv. & $\$ 19,671.75$ & $\$ 5,794.25$ & $\$ 13,877.50$ & \multirow{2}{*}{$\$ 4,718.25$} \\
\hline TOTAL & Green & $\$ 24,500.72$ & $\$ 9,478.22$ & $\$ 15,022.50$ & \\
\hline \multicolumn{5}{|c|}{ GREEN Labor + Materials Costs: $\$ 24,501$} & $L+M$ \\
\hline \multicolumn{5}{|c|}{ CONVENTIONAL Labor + Material Costs: $\$ 19,671$} & $L+M$ \\
\hline
\end{tabular}


Table 5.1 summarizes the costs of the original green upgrades as compared to the conventional equivalents. Overall, the cost of labor and material needed to implement the original green upgrades in the County’s NSP2 application combined came to $\$ 24,501$, compared to $\$ 19,671$ for the conventional equivalents. (As a reminder, the County had budgeted $\$ 15,000$ for its green upgrades commitment.) The total cost of the green upgrades exceeded the conventional equivalents by $\$ 4,718$, most of which was contributed by an additional in materials costs at $\$ 3,684$, though additional labor costs $\$ 1,144$ also contributed, as found by subtracting the difference in total green and conventional material and labor costs, in Table 5.1. The green premium, the average price difference between individual green and conventional upgrades, is $\$ 363$. One of the upgrades was actually less expensive in the green version than conventional version; this was the green refrigerator, as Home Depot did not carry any conventional refrigerators below the regular price of its green models. The greatest price difference for a single upgrade between the green and conventional version was the flooring - the price difference between the bamboo and conventional laminate was $\$ 2,297$. This raises the question if another zero-VOC flooring could have been less expensive and still improved indoor air quality, although bamboo is a renewable natural resource and its production may potentially have less environmental impact than synthetic materials. Overall the most expensive original green upgrade was the dual-paned windows at $\$ 7,975$. (This high cost coupled with information that ceiling insulation typically yields a much greater benefit than dual pane windows prompted window upgrades to be eliminated from the alternative upgrade set.) The three least expensive green upgrades at $\$ 87, \$ 110$, and $\$ 186$ (for materials plus labor) were the low-flow showerhead, weatherstripping, and new kitchen sink faucet with aerator, respectively. These three affordable upgrades seemed a good fit for the County's tight budget, and were retained in the alternative upgrade strategy. 


\section{Benefits - Energy Savings}

Estimates for the dollar value and amount of the energy that would be saved by implementing the original green upgrades per the NSP2 application were projected with an online calculator from the Lawrence Berkeley National Laboratory (LBNL) (LBNL, 2010). The LBNL calculator was also used to estimate the reduction in greenhouse gas emissions from implementing the upgrades. This calculator, called Home Energy Saver ${ }^{\mathrm{TM}}$, was used to generate the figures for the existing house configuration ("baseline") and for the home under the original upgrades configuration (Appendix D1 and D2, respectively). For each configuration of the home model, the calculator was loaded with information on all energy draws (i.e., appliances) including age, efficiency, and hours of use. Specifically, the following information on appliances, construction features, and climate were loaded into the LBNL calculator:

- room sizes and overall house size

- foundation type

- window placement, type, and size

- ceiling and wall insulation type and amount

- ventilation, heating, and cooling system type

- types and ages appliances

- number of occupants

- climate, comparable with nearest large US city

The LBNL calculator then factors in construction features of the house model that reduce energy needs (such as insulation and building orientation), as well as local climate, another important aspect of home energy usage. The LBNL calculator used climate and energy usage data for Oakland, California (the nearest large US city with a comparable climate) that was collected in studies in 1992 and 1997. Finally, to estimate energy costs, the LBNL 
calculator used state energy rates for electricity and natural gas to generate expected costs. Specifically, the rates used were the California state average prices for electricity and natural gas in year 2009, as reported by the Energy Information Administration (LBNL, 2010). Estimates for both the existing home ("baseline") and the upgraded home configuration are shown in Table 5.2. The energy and dollar savings figures reported are the difference between the baseline and original upgrades. (Appendix D1 and D2 are the LBNL reports which includes details of input for each configuration.) 


\section{Benefits - Water Savings}

Water usage and projected water use reductions attributed to implementation of the original green upgrades per the NSP2 application were estimated with an online calculator from the City of Tampa, Florida (City of Tampa, 2010). (The outdoor water usage portion of the calculator was omitted, as no upgrades addressed outdoor water usage.) The Tampa water calculator takes into account the following parameters:

- household size

- fixture flow rate (toilets, faucets, and showerhead)

- volume used by water-using devices (dishwasher and clothes washer)

- duration or frequency of fixture or appliance usage

Each of these parameters can be customized, or set on the defaults. To analyze water usage for the existing home model, the default settings for water fixtures and water-using appliances were used, as this information was unknown. For the analysis of the original green upgrades, the flow rates of the particular water fixtures and usage rate of the appliances reported by the manufacturer (as relayed on the retailer's website) were loaded into the calculator. For duration and frequency of usage, I assumed:

- 1 shower (0 baths) per person daily (20 minutes long)

- 5 total hand washing, shaving, or tooth brushing sessions per person daily (4 minutes long)

- 1 laundry load person per week, plus 1 shared load for all members

- dishwasher used 2 times a week, dishes hand washed 4 times daily (8 minutes long) Water usage was then converted into estimated costs by using the local water provider EBMUD's rates (EBMUD, 2010). EBMUD single-family homes using less than the threshold limits are charged flat rates; households exceeding the second threshold are charged per every additional 100 cubic feet of water over the threshold. The energy and dollar savings figures reported are the difference between the baseline and original upgrades. 


\section{Summary of Benefits from Original Upgrades}

Table 5.2. Estimated utility usage and GHG emissions of baseline home and original green upgrades. Annual savings, 10 year savings, and payback period for upgrades also shown.

\begin{tabular}{|l|r|l|l|r|}
\hline ENERGY & $\begin{array}{l}\text { Annual } \\
\text { KwH Used }\end{array}$ & $\begin{array}{l}\text { Annual } \\
\text { Therms } \\
\text { Used }\end{array}$ & $\begin{array}{l}\text { Annual } \\
\text { Energy } \\
\text { Cost }\end{array}$ & $\begin{array}{l}\mathrm{CO}_{2} \text { lbs } \\
\text { Emitted }\end{array}$ \\
\hline Baseline & 5,837 & 495 & $\$ 1,470$ & 8,695 \\
\hline Original Upgrades & 5,111 & 409 & $\$ 1,255$ & 7,328 \\
\hline
\end{tabular}

\begin{tabular}{|l|r|l|l|}
\hline WATER & $\begin{array}{l}\text { Daily Per } \\
\text { Capita }\end{array}$ & $\begin{array}{l}\text { Annual } \\
\text { Gallons } \\
\text { Used }\end{array}$ & $\begin{array}{l}\text { Annual } \\
\text { Water Cost }\end{array}$ \\
\hline Baseline & 199 & 217,905 & $\$ 1,207$ \\
\hline Original Upgrades & 105 & 114,975 & $\$ 905$ \\
\hline
\end{tabular}

\begin{tabular}{|c|l|l|l|l|l|}
\hline $\begin{array}{l}\text { Payback and } \\
\text { Cost-Benefit }\end{array}$ & $\begin{array}{l}\text { Annual } \\
\text { Savings }\end{array}$ & $\begin{array}{l}\text { Cost to } \\
\text { Upgrade }\end{array}$ & $\begin{array}{l}\text { Payback } \\
\text { Period in } \\
\text { Years }\end{array}$ & $\begin{array}{l}10 \text { Year } \\
\text { Savings }\end{array}$ & $\begin{array}{l}\mathrm{CO}_{2} \mathrm{lbs} \\
\text { Saved } \\
\text { Annually }\end{array}$ \\
\hline Original Upgrades & $\$ 517$ & $\$ 24,179.72$ & 46.77 & $\$ 5,170$ & 1,367 \\
\hline
\end{tabular}

Table 5.3 Estimated payback periods for original upgrades, by sector.

\begin{tabular}{|c|r|c|c|}
\hline \multicolumn{4}{|c|}{ Original Upgrades Savings \& Paybacks By Sector } \\
\hline Upgrade & Cost $(\mathrm{L}+\mathrm{M})$ & $\begin{array}{c}\text { Annual } \\
\text { Savings }\end{array}$ & $\begin{array}{c}\text { Payback } \\
\text { (in Years) }\end{array}$ \\
\hline WATER & $\$ 2,653.87$ & $\$ 302$ & 8.8 \\
\hline ENERGY & $\$ 12,972.57$ & $\$ 215$ & 60.3 \\
\hline AIR QUALITY & $\$ 8,874.28$ & unknown & unknown \\
\hline All Upgrades & $\$ 24,500.72$ & $\$ 517$ & \\
\hline
\end{tabular}

Monetary benefits of the green upgrades would result from reduced use of natural gas, electricity, and water, which would subsequently lower residents' utility bills. The utility savings estimates in this analysis should be considered conservative estimates, as they do not account for future energy and water cost increases. With this factor in mind, the original Contra Costa County's original green upgrades per the NSP2 application would be expected to save $\$ 517$ dollars a year in water and energy bills (see Table 5.2 ). These savings, across ten years, would amount to $\$ 5,170$. When corrected for net present value (using a discount 
rate of $5 \%$, as in Bradshaw's similar cost-benefit analysis), the cash flow amount reduces to $\$ 3,992$ (Bradshaw et al., 2005; Investopedia, 2010). The LBNL calculator also projected that the energy efficiency upgrades would reduce greenhouse gas emission by 1,367 pounds of carbon dioxide annually. (Non-monetary and indirect benefits will be discussed in the Chapter 9.) The payback period needed to recover the initial costs of all original upgrades was estimated at over 47 years, as in Table 5.2 .

In Table 5.3, payback periods were analyzed by sector by allocating upgrade costs and utility savings to the water, air quality, or energy sector, as appropriate. In the instance of upgrades that improved both energy and water efficiency (such as the dishwasher), half the cost was allocated to each sector. Broken down by sector, the payback period of the original water efficiency upgrades was dramatically shorter, at 8.8 years, compared to the original energy efficiency upgrades, at over 60 years. In addition to the lower initial cost, the water upgrades have higher annual savings than the energy upgrades. This suggests that original water efficiency upgrades proposed are significantly more cost-effective than the original energy upgrades. Due to the imprecision of monetizing the air quality benefits (which directly benefit health), benefits from air quality were considered unknown. 


\section{Chapter 6.0 - Alternative Green Upgrades}

In this section, the alternative upgrades are listed then interpreted, applied, and cost estimated for the home model. The alternative upgrades set was formulated subsequent to review of a variety of energy and water efficiency strategies. Sources included government websites, professional and academic literature, recommendations of architecture Professor Di Santo, and the results of the utility calculators. (See the following material selection sections for specifics.) The research suggested that the cost-benefit performance of the County's original green upgrades could be improved upon; that is, a different set of upgrades could be less expensive and could save even more water and energy, reducing bills even further than the original upgrades.

Table 6.1. Alternative green upgrades, as compared to original green upgrades.

\begin{tabular}{|c|}
\hline ORIGINAL UPGRADES \\
\hline Appliance - Clotheswasher \\
\hline Appliance - Dishwasher \\
\hline Appliance - Refrigerator \\
\hline Bathroom Fan \\
\hline Flooring \\
\hline Lights - Bathroom \\
\hline Lights - Room \& Outside \\
\hline Painting \\
\hline Water Fixture - Bath Sink Faucets \\
\hline Water Fixture - Kitchen Faucet \\
\hline Water Fixture - Showerhead \\
\hline Water Fixture - Toilets \\
\hline Weatherstripping (outside door) \\
\hline Windows \\
\hline
\end{tabular}

\begin{tabular}{|c|}
\hline ALTERNATIVE UPGRADES \\
\hline Appliance - Clotheswasher \\
\hline Appliance - Dishwasher \\
\hline Appliance - Refrigerator \\
\hline Bathroom Fan \\
\hline Ceiling Fans - NEW \\
\hline Clothesline - NEW \\
\hline Flooring \\
\hline Insulation - NEW \\
\hline Lights - Bathroom \\
\hline Lights - Room \& Outside \\
\hline Painting \\
\hline Thermostat - NEW \\
\hline Water Fixture - Bath Sink Faucets \\
\hline Weatherstripping (outside door) \\
\hline Water Fixture - Kitchen Faucet Aerator - New \\
\hline Water Fixture - Showerhead \\
\hline
\end{tabular}


The alternative set was formulated by maintaining the NSP2 program goals of improved water efficiency, energy efficiency, and improved indoor air quality, as well as using the original upgrades as the starting point from which the alternative set would be formulated. The formulation strategy was to 1) eliminate or replace expensive upgrades with low-cost alternatives that could achieve similar or better performance, and 2) add low-cost upgrades research suggested could significantly improve water or energy savings. As shown in Table 6.1, the original upgrades proposed in the County NSP2 application were adjusted with following eight amendments:

Addition of:

- ceiling fans

- ceiling insulation

- clotheslines

- energy star water heater

- programmable thermostat

Exchange of:

- toilet tank displacement bags (instead of new dual flush toilets)

- kitchen faucet aerator (instead of new kitchen faucet plus aerator)

Elimination of:

- dual pane windows

\section{Material Selection and Labor Cost Estimation}

Material cost estimates and labor cost estimates for the alternative upgrades were collected simultaneously with the original upgrades using the same methods that generated the original upgrade cost estimates. Because the majority of the upgrades in the alternative set are identical to the original upgrades, this section only details the selection and cost estimation for the amendments (additions, substitutes, and eliminations). Since all cost 
estimates for materials and labor were collected item-by-item, this allowed for the contents of the two green upgrade sets to be tailored at a later date, while maintaining consistency and comparableness across sets.

For brevity, this chapter presents upgrade summaries with a general description of the product, with the price of material and labor combined. The general principle behind the upgrade (improving air quality, or water and/or energy efficiency) is also discussed in the pertinent sections. As with the original upgrades, each additional or substitute upgrade was converted into specifics, appropriately sized for the home model created for this study (see Chapter 3). Material selection had two components: amount or size, and model and brand. Method of calculation for sizing or amount of products varied accordingly with the model home feature under study, as described in the appropriate section. For full details, see Appendix A2 which details the specifics of the products selected to implement the alternative upgrades: the model, brand, amount or size, retailer item number, along with item-by-item material costs and labor cost quotes from a respected local contractor. Most materials were estimated at major home improvement retailer Home Depot through their website or during trips made in person. The two exceptions are the toilet tank displacement bag, which could only be found online at Amazon.com, and the ceiling insulation that was cost estimated through Bay Valley Insulation, Inc., a local roofing specialist (Roth, G., personal communication, May 12, 2010). The brand and model selected for each upgrade were "economy" versions; that is, the cost and item number of the lowest-priced item available was recorded, unless it received a significant number of negative customer comments (more than a third of posted comments) on the website. In these instances, a slightly more expensive model was selected with fewer negative comments. Finally, the full price (not sales price) was recorded. 
Ceiling Fans

Table 6.2 Ceiling Fan Materials And Installation Cost

\begin{tabular}{|c|l|c|}
\hline Ceiling Fans & $\begin{array}{l}\text { Economy } \\
\text { models, } \\
\text { (4 large, 1 small) }\end{array}$ & $\$ 1,222.85$ \\
\hline
\end{tabular}

Home cooling needs were addressed with ceiling fans. Two-thirds of homes in the US have air conditioning units, and on average each use enough electricity to emit two tons of carbon into the atmosphere annually (DoE, 2009b). In temperate climates, or during moderately hot weather, ceiling fans may allow residents may to avoid air conditioners altogether. Ceiling fans are considered the most effective circulating fans, creating a draft that results in a wind chill effect on the skin (DoE, 2010a). The energy and carbon savings from this alternative upgrade expected to be appreciable in the benefits analysis.

Although Energy Star rates ceiling fans, no online retailer searched carried these models. Hence, the lowest cost models of appropriately sized fans were selected. A total of 5 ceiling fans were sized and cost estimated for each of the three bedrooms, the living room, and kitchen (Energy Star, n.d.b). These ceiling fans would be installed in place of five existing single bulb fixtures, each fan having a built-in light to maintain ceiling light function. The exception was in the converted garage bedroom, where no light fixture previously existed. The labor contractor was asked for the cost to wire the converted garage bedroom for the ceiling fan in a line-by-line green upgrade labor estimate quote. A corollary of installing five ceiling fans into overhead single bulb fixtures space is that five fewer Energy Star single bulb fixtures are needed compared to the original green upgrades configuration. Table 6.3 illustrates the configuration schemes, further detailed in Appendix B. (Note that the laundry room light was consistently omitted from both original and alternative upgrades.) 
Table 6.3. Bulb replacement scheme for ceiling fans and Energy Star fixtures. Baseline, original upgrades, and alternative green upgrade configurations shown. See Appendix B for details.

\begin{tabular}{|l|l|l|}
\hline \multicolumn{1}{|c|}{ BASELINE } & \multicolumn{1}{|c|}{$\begin{array}{c}\text { ORIGINAL } \\
\text { UPGRADES }\end{array}$} & $\begin{array}{l}\text { ALTERNATIVE } \\
\text { UPGRADES }\end{array}$ \\
\hline 0 ceiling fans & 0 ceiling fans & ceiling fans \\
\hline 9 single bulbs* & $\begin{array}{l}9 \text { Energy Star } \\
\text { fixtures + bulbs }\end{array}$ & $\begin{array}{l}4 \text { Energy Star } \\
\text { fixtures + bulbs }\end{array}$ \\
\cline { 2 - 3 } $\begin{array}{l}\text { *laundry room } \\
\text { light omitted }\end{array}$ & $\begin{array}{l}\text { (1 newly wired } \\
\text { single bulb } \\
\text { fixture })\end{array}$ & $\begin{array}{l}\text { (1 newly wired } \\
\text { ceiling fan })\end{array}$ \\
\hline
\end{tabular}

\section{Ceiling Insulation}

Table 6.4 Ceiling insulation materials and labor cost.

\begin{tabular}{|c|l|c|}
\hline $\begin{array}{c}\text { Ceiling } \\
\text { Insulation }\end{array}$ & $\begin{array}{l}\text { Flat ceiling, labor } \\
\text { and materials. }\end{array}$ & $\$ 2,782.50$ \\
\hline
\end{tabular}

HUD considers insulation a moderate-cost home rehabilitation item, and an effective way to address one of the primary sources of energy loss. Also according to a 2008 manual from HUD, adding ceiling insulation has a short payback period, making it cost-effective and appropriate for affordable housing (HUD, 2008 p. 58, 62). Because the home model was built prior to newer building codes, knob-and-tube wiring is assumed, which is not compatible with wall insulation. If insulation were to be added to the walls, an electrician would need to modify the knob-and-tube wiring in the walls. Further, in terms of effectiveness, ceiling insulation is far superior to wall insulation (Di Santo, T., personal communication, April 7, 2010). Thus, to reduce costs, only ceiling insulation was upgraded. Insulation is given an R-value, and the extent to which the insulation resists heat flow, limiting heat transfer. R-38 is recommended for ceilings, and is relatively easy to achieve in homes with pitched roofs and attics (HUD, 2008, p. 62). However, the home model has no 
attic; it has a flat roof (also known as a composite roof). According to Di Santo and the contractor, the home model (based on the Karen Road home, see Chapter 3) is likely to be an 8 to 9 inch gap between the ceiling and roof, which could accommodate insulation that would be rated as R-21. Since Hodge Construction (the labor contractor used for all other work) did not have expertise in insulation, a local contractor specializing in insulation was given the home model specifics and asked for a quote for the blown-in insulation. This insulation product is formaldehyde-free cellulose, made from materials such as recycled newspapers. The quote in Table 6.4 from Bay Valley, Inc. manager Guy Roth includes costs for labor and blown-in cellulose insulation materials (Roth, G. personal communication, April 5, 2010).

\section{Clotheslines}

Table 6.5 Clothesline materials and installation cost.

\begin{tabular}{|l|l|c|}
\hline Clothesline & $\begin{array}{l}\text { Retractable } \\
\text { clotheslines }\end{array}$ & $\$ 143.88$ \\
\hline
\end{tabular}

According to the California Energy Commission (CEC), clothes dryers are usually the second-highest energy drawing home appliance, after refrigerators (CEC, 2010a). Energy Star does not rate clothes dryers, stating that research has shown no appreciable difference in energy efficiency between models (Energy Star, n.d.c). As Energy Star does not label clothes dryers, they did not fall under the original upgrades commitment to replace existing appliances with Energy Star rated appliances. However, clotheslines would have met the energy efficiency and cost saving goal, as clotheslines use the power of the sun and wind, providing a (nearly) free service and also preventing greenhouse gas emissions. Since Richmond historical weather data reports station reports average temperatures above $70^{\circ} \mathrm{F}$ for six months of the year, it was assumed that clotheslines could be used to dry all laundry 
for half the year, thereby reducing annual dry usage by half (see Figure 3.7). Cost estimates for three retractable clotheslines installed in the backyard are listed in Table 6.5.

\section{Programmable Thermostat}

Table 6.6 Programmable digital thermostat materials and installation cost.

\begin{tabular}{|c|l|c|}
\hline $\begin{array}{c}\text { Digital } \\
\text { Thermostat }\end{array}$ & $\begin{array}{l}\text { Economy model } \\
\text { programmable } \\
\text { thermostat }\end{array}$ & $\$ 109.00$ \\
\hline
\end{tabular}

Programmable thermostats (typically digital) turn off the heating or air conditioning when the air achieves pre-set temperatures designation, maintaining a home at comfortable temperatures while occupied by but allowing the home to swing outside comfortable temperatures while the residents are away or sleeping. Programmable thermostats are considered a "key component" of energy efficiency, and are more convenient and accurate than manual thermostats. According to DoE and HUD, when used properly, households can save $\$ 150$ to $\$ 180$ a year, or at least $15 \%$, on energy bills (HUD, 2008, p62; DoE, 2010b; CEC, 2006). The home model did not specify the location of the existing thermostat, but it was assumed that the existing thermostat was properly located (away from direct light or windows), and therefore would not need additional labor to be repositioned (DoE, 2010b). The digital thermostat selected was the lowest priced programmable model available at the retailer.

\section{Kitchen Faucet Aerator}

Table 6.7 Kitchen faucet aerator materials and installation cost.

\begin{tabular}{|c|c|c|}
\hline $\begin{array}{c}\text { Water Fixture - } \\
\text { Kitchen Faucet } \\
\text { Aerator }\end{array}$ & Alternative & $\$ 36.00$ \\
\hline
\end{tabular}

Bath and kitchen faucets account for more than $15 \%$ of indoor household water use.

Older kitchen faucets can use as much as 4 to 7 gallons per minute (EEP, 2010a). One way 
to reduce water usage is to reduce flow rate of the fixture. Kitchen faucet aerators can reduce flow by $30 \%$ to as little as 2.2 gallons per minute. Aerators add air to the water stream with a sieve-like action, actually increasing the area of coverage and not sacrificing performance, yet conserving water (EEP, 2010b).

The original upgrade committed the County to replacing the fixtures with WaterSense labeled fixtures, necessitating the additional cost of a new kitchen faucet. Under the alternative upgrade approach, the kitchen faucet upgrade would be more aptly described as modification of the existing kitchen fixture to reduce flow rate. Since the original upgrade cost estimate was identical but included the new faucet, therefore the cost estimate for the alternative was simply the same, but subtracting the new faucet cost, thus it just covered the aerator and labor. This estimate is shown in Table 6.7.

Toilet Displacement Bags

Table 6.8 Toilet tank displacement materials and installation cost.

\begin{tabular}{|c|l|c|}
\hline $\begin{array}{c}\text { Water Fixture }- \\
\text { Toilets Tank } \\
\text { Bag }\end{array}$ & $\begin{array}{l}\text { Toilet tank } \\
\text { displacement } \\
\text { bags }\end{array}$ & $\$ 67.98$ \\
\hline
\end{tabular}

Toilets prior to the 1970s used as much as 7 gallons per flush, while those built in the 1980s used 5.5 to 3.5 gallons per flush (EPA, 2008a; City of Roseville, n.d.). New toilets today use 1.6 gallons per flush, or even as little as 1.28 gallons per flush. The difference in water usage is substantial, and when multiplied across multiple users flushing several times a day for 365 days a year, the difference of thousands of gallons make toilets an serious target for water conservation. While toilet replacement would save much more water, using a displacement bag (which takes up space in the toilet tank, thereby reducing flushing volume) is less expensive in terms of material and labor. In addition, use of toilet displacement bags instead of replacing a toilet prevents a disposed toilet from taking up landfill space, and does not necessitate a new toilet being manufactured, which saves 
material and energy (Alliance For Water Efficiency, 2010). It should also be noted that materials costs could be zero: free devices are offered from the local water provider, EBMUD, and would be available to any County employee bearing an employee ID card and evidence that the home they were gathering devices for was owned by the County (for instance, the title report). The toilet tank bag, the only model found, was cost estimated at Amazon.com (the only retailer found to carry the item). Labor, which consists of filling the bag with water and placing it in the toilet tank, was not quoted from the contractor, but was conservatively estimated based on showerhead replacement cost. Finally, displacement bags are not appropriate for toilets that use less than 3.5 gallons per flush, and have been described as a temporary solution, as they have a fixed lifetime (Alliance for Water Efficiency, 2010). However, the bags can be replaced in the future.

Water Heater

Table 6.9 Water heater materials and installation cost.

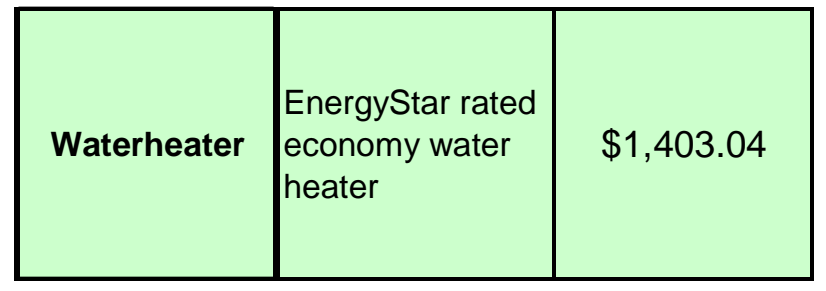

Water heaters consume between $14 \%$ and $25 \%$ of household energy (DoE, 2009c). One strategy to reduce energy usage and energy bills is to replace older water heaters with a newer model, since modern models are much more energy efficient than models made in decades past (CEC, 2010b). An Energy Star qualified gas storage water heater is expected to save $\$ 30$ a year over a standard water heater (Energy Star, n.d.d). In California natural gas to heat water as it is less expensive than electricity, and according to the 2000 Census, most homes in the Montalvin Census Tract use natural gas for heating. As such, it was assumed that the Montalvin model home has an existing natural gas water heater (Census 
Bureau, n.d., CEC, 2010b). The gas storage water heater model selected was an economy Energy Star model available at Home Depot. Its manual indicates that a water heater blanket was unnecessary (Rheem Manufacturing Co., 2006). The 50-gallon size is the midrange sizing recommendation for a 1.5 bathroom, 3 bedroom home from a state of California energy saving organization (EEP, 2010c). The cost estimate for materials and labor for the water heater are shown in Table 6.9. (Note that other more efficient water heater options, such as tankless heaters, are encouraged in formulating future programs, if budget allows for the higher expense.)

\section{A Note on Dual Pane Windows Elimination}

For improved cost-effectiveness, the measure to upgrade existing windows to dual pane windows was eliminated. According to Professor Di Santo and cost findings from the original upgrades section, the dual pane windows were both expensive and low performing (personal communication, April 9, 2010). Instead, to improve building envelop performance, ceiling insulation was included. See ceiling insulation section and Table 6.4. 


\section{Chapter 7.0 - Findings for Alternative Green Upgrades}

Cost

Table 7.1 Alternative upgrade set itemized material and labor costs. New upgrades are indicated in the "set" column.

\begin{tabular}{|c|c|c|c|c|}
\hline ITEM & Set & Cost $L+M$ & $\begin{array}{c}\text { Cost - } \\
\text { Material }\end{array}$ & $\begin{array}{l}\text { Cost - } \\
\text { Labor }\end{array}$ \\
\hline $\begin{array}{c}\text { Appliance - } \\
\text { Clothes Washer }\end{array}$ & Original & $\$ 848.00$ & $\$ 448.00$ & $\$ 400.00$ \\
\hline $\begin{array}{l}\text { Appliance - } \\
\text { Dishwasher }\end{array}$ & Original & $\$ 849.00$ & $\$ 399.00$ & $\$ 450.00$ \\
\hline $\begin{array}{l}\text { Appliance - } \\
\text { Refrigerator }\end{array}$ & Original & $\$ 758.00$ & $\$ 698.00$ & $\$ 60.00$ \\
\hline $\begin{array}{l}\text { Ceiling Fans } \\
\text { (with lights) }\end{array}$ & Alternative & $\$ 1,222.85$ & $\$ 247.85$ & $\$ 975.00$ \\
\hline $\begin{array}{l}\text { Ceiling } \\
\text { Insulation }\end{array}$ & Alternative & $\$ 2,782.50$ & $\$ 2,782.50$ & $\$ 0.00$ \\
\hline Clothesline & Alternative & $\$ 143.88$ & $\$ 53.88$ & $\$ 90.00$ \\
\hline $\begin{array}{c}\text { Digital } \\
\text { Thermostat }\end{array}$ & Alternative & $\$ 109.00$ & $\$ 39.00$ & $\$ 70.00$ \\
\hline Flooring & Original & $\$ 5,672.24$ & $\$ 3,672.24$ & $\$ 2,000.00$ \\
\hline $\begin{array}{l}\text { Lights \& Fans } \\
\text { with Lights for } \\
\text { Bathrooms }\end{array}$ & Original & $\$ 1,244.00$ & $\$ 344.00$ & $\$ 900.00$ \\
\hline $\begin{array}{l}\text { Lighting - Indoor } \\
\& \text { Outdoor } \\
\text { (excludes } \\
\text { bathrooms) }\end{array}$ & Original & $\$ 1,314.35$ & $\$ 161.85$ & $\$ 1,152.50$ \\
\hline Paint & Original & $\$ 3,202.04$ & $\$ 352.04$ & $\$ 2,850.00$ \\
\hline $\begin{array}{l}\text { Water Fixture - } \\
\text { Bath Faucets }\end{array}$ & Original & $\$ 516.00$ & $\$ 116.00$ & $\$ 400.00$ \\
\hline $\begin{array}{c}\text { Water Fixture - } \\
\text { Kitchen Faucet } \\
\text { Aerator }\end{array}$ & Alternative & $\$ 36.00$ & $\$ 6.00$ & $\$ 30.00$ \\
\hline $\begin{array}{c}\text { Water Fixture - } \\
\text { Showerhead }\end{array}$ & Original & $\$ 87.87$ & $\$ 12.87$ & $\$ 75.00$ \\
\hline $\begin{array}{l}\text { Water Fixture - } \\
\text { Toilets Tank Bag }\end{array}$ & Alternative & $\$ 67.98$ & $\$ 7.98$ & $\$ 60.00$ \\
\hline Waterheater & Alternative & $\$ 1,403.04$ & $\$ 603.04$ & $\$ 800.00$ \\
\hline $\begin{array}{l}\text { Weather- } \\
\text { stripping }\end{array}$ & Original & $\$ 110.72$ & $\$ 35.72$ & $\$ 75.00$ \\
\hline TOTAL & $\begin{array}{c}\text { Alternative } \\
\text { Upgrades Set }\end{array}$ & $\$ 20,367$ & $\$ 9,980$ & $\$ 10,388$ \\
\hline
\end{tabular}


The cost estimate for the alternative upgrades set is shown in Table 7.1, with itemized labor and materials cost estimates for each individual upgrade. (The details such as brand, model, and Home Depot item number are provided in Appendix A2.) Note that the full set of alternative upgrades is the combination of the additional or changed upgrades (such as ceiling fans and toilet tank bags) indicated as "alternative," plus the unchanged original upgrades (such as weatherstripping) indicated as "original." Overall, the total estimated cost of implementing the alternative upgrade set is $\$ 20,376$, with approximately half of costs attributed to materials $(\$ 9,980)$ and half attributed to labor $(\$ 10,388)$. It is interesting to note that for the original upgrade set, the ratio of estimated labor/material cost ratio is one-third material cost to two-thirds labor cost. In the alternative upgrades, the ratio is half material cost and half labor cost. It is likely that the labor cost could reduced if groups such as the non-profit workforce development programs Rising Sun (of the San Francisco Bay Area) or Community Action Network (nationwide) provided labor for basic labor such as installing clotheslines, weatherstripping, faucet aerators, and toilet tank displacement bags. The greatest contributor to upfront cost savings over the original upgrade set was elimination of the dual pane windows, saving $\$ 7,975$. This savings is more than the combined cost of the additional seven new/modified upgrades added $(\$ 5,743)$, which includes the cost of ceiling insulation. It should also be noted that the two original upgrades that were exchanged/modified for lower cost strategies saved $\$ 150$ and $\$ 518$, respectively. These were adding a kitchen faucet aerator to the existing faucet (instead of a new low-flow kitchen faucet) and using toilet tank bags (instead of buying new low-flow toilets).

Another interesting finding, in regards to specific upgrades, is that the two most expensive alternative upgrades were the bamboo flooring and zero-VOC paint-both intended to improve indoor air quality-at $\$ 5,672$ and $\$ 3,202$, respectively. In the case of the zero-VOC paint, the labor cost estimate portion accounted for $90 \%$ of the costs, far outweighing the materials cost. This is partially due to additional contractor fees for meeting the lead paint testing and certification requirements of the EPA (under the Toxic Substances 
Control Act), because the home was built before 1978 and would be painted by a contractor (EPA, 2010d). In the case of the bamboo flooring, however, the materials cost $(\$ 3,672)$ exceeded labor cost estimates $(\$ 2,000)$. Bamboo is a promoted as a sustainable wood product, which is one reason it was selected as an original upgrade. However, due to the high cost, substitute non-VOC flooring might be preferred in formulating future upgrade programs.

\section{Summary of Benefits from Alternative Upgrades}

Table 7.2. Estimated utility usage and GHG emissions of baseline home, original upgrades, and alternative upgrades. Annual savings, 10-year savings, and payback period for upgrades also shown.

\begin{tabular}{|c|c|c|c|c|c|}
\hline ENERGY & $\begin{array}{l}\text { Annual } \\
\text { KwH Used }\end{array}$ & \begin{tabular}{|l|} 
Annual \\
Therms \\
Used \\
\end{tabular} & \begin{tabular}{|l|} 
Annual \\
Energy \\
Cost \\
\end{tabular} & $\begin{array}{l}\mathrm{CO}_{2} \mathrm{lbs} \\
\text { Emitted }\end{array}$ & \\
\hline \begin{tabular}{|l} 
Baseline \\
\end{tabular} & 5,837 & 495 & $\$ 1,470$ & 8,695 & \\
\hline Original Upgrades & 5,111 & 409 & $\$ 1,255$ & 7,328 & \\
\hline Alternative Upgrades & 4,279 & 328 & $\$ 1,032$ & 5,967 & \\
\hline WATER & $\begin{array}{l}\text { Daily Per } \\
\text { Capita }\end{array}$ & $\begin{array}{l}\text { Annual } \\
\text { Gallons } \\
\text { Used }\end{array}$ & \begin{tabular}{|l|} 
Annual \\
Water Cost
\end{tabular} & & \\
\hline Baseline & 199 & 217,905 & $\$ 1,207$ & & \\
\hline Original Upgrades & 105 & 114,975 & $\$ 905$ & & \\
\hline Alternative Upgrades & 118 & 129,210 & $\$ 905$ & & \\
\hline $\begin{array}{l}\text { Payback and } \\
\text { Cost-Benefit }\end{array}$ & $\begin{array}{l}\text { Annual } \\
\text { Savings }\end{array}$ & $\begin{array}{l}\text { Cost to } \\
\text { Upgrade }\end{array}$ & $\begin{array}{l}\text { Payback } \\
\text { Period in } \\
\text { Years }\end{array}$ & $\begin{array}{l}10 \text { Year } \\
\text { Savings }\end{array}$ & $\begin{array}{l}\mathrm{CO}_{2} \text { lbs } \\
\text { Saved } \\
\text { Annually }\end{array}$ \\
\hline Original Upgrades & $\$ 517$ & $\$ 24,179.72$ & 46.77 & $\$ 5,170$ & 1,367 \\
\hline Alternative Upgrades & $\$ 740$ & $\$ 21,176.48$ & 28.62 & $\$ 7,400$ & 2,728 \\
\hline
\end{tabular}

Table 7.3 Estimated payback periods for alternative upgrades, by sector.

\begin{tabular}{|c|r|c|c|}
\hline \multicolumn{4}{|c|}{ Alternative Upgrades Savings \& Paybacks By Sector } \\
\hline Upgrade & Cost $(\mathrm{L}+\mathrm{M})$ & $\begin{array}{c}\text { Annual } \\
\text { Savings }\end{array}$ & $\begin{array}{c}\text { Payback } \\
\text { (in Years) }\end{array}$ \\
\hline WATER & $\$ 1,935.35$ & $\$ 302$ & 6.4 \\
\hline ENERGY & $\$ 9,557.84$ & $\$ 438$ & 21.8 \\
\hline AIR QUALITY & $\$ 8,874.28$ & unknown & unknown \\
\hline All Upgrades & $\$ 20,367.47$ & $\$ 740$ & \\
\hline
\end{tabular}


The same methods and tools used to estimate the monetary benefits (i.e., utility savings) from implementation of the original upgrades were used to generate the projections for the alternative upgrades. Energy usage was projected with the LBNL calculator, and water usage was projected with the City of Tampa water usage calculator (LBNL, 2010; City of Tampa, 2010). (See Chapter 5 for greater detail.) Inputs representing the original upgrades were changed to reflect the new configurations. Specifically, the LBNL energy calculator inputs were changed to reflect the new alternative upgrades energy-saving features--ceiling fans, ceiling insulation, digital thermostat, and water heater were added; the dual pane windows from the original set were reversed to single pane windows, as these had been omitted from the alternative upgrades set. The Tampa water use calculator inputs were unchanged, except to reflect the toilet tank displacement bags (the alternative green upgrade). The original upgrade for the toilet proposed replacing the existing toilet with a WaterSense labeled a low-flow, dual flush toilet, and this was represented in the calculator by the WaterSense standard of 1.28 gallons per flush rate (see Table 4.5). The alternative upgrade, the toilet tank displacement bags, would lower the amount of water used by the existing toilet by 0.625 gallons ( 2.5 quarts). The calculator default of 5 gallons per flush was assumed representative of the baseline (existing) toilet, thus the flush rate used for the alternative green upgrade is 4.375 gallons per toilet flush.

Table 7.2 compares the projected monetary benefits and resource conservation potential of the alternative upgrades with original upgrades and the baseline (existing) home. The alternative upgrades are projected to outperform the original upgrades in all sectors, with the exception of slightly higher water usage. The alternative upgrades save an additional \$223 dollars over the original upgrades, bringing the estimated combined water and energy bills for alternative upgrades configuration to $\$ 1,937$ annually. This would be $28 \%$ lower than the existing home's combined water and energy bills estimated at $\$ 2,677$ annually. Annual carbon dioxide emissions would also be reduced by one-third. The existing 
home configuration is estimated to emit $8,695 \mathrm{lbs}$ annually, while the alternative upgrades would reduce emissions to an estimated $5,967 \mathrm{lbs}$. It is important to explain that while annual water usage is 14,235 gallons lower under the original upgrades than under the alternative upgrades, because of the threshold structure of the local provider EBMUD, the water usage fee does not increase, making the charge $\$ 905$ annually under both upgrade configurations. Together, the savings from the higher energy and water efficiency across ten years would amount to $\$ 7,400$. When corrected for net present value (using a discount rate of $5 \%$, as in Bradshaw et al.'s similar cost-benefit analysis), the net present value of the cash flow amounts to $\$ 5,714$ (Bradshaw et al., 2005; Investopedia, 2010). (Non-monetary and indirect benefits will be discussed in Chapter 9.)

The combined payback period of the alternative upgrades, noted in Table 7.2, is 27.5 years, compared to 47.4 years for the original upgrades (see Table 5.2). To analyze the upgrades sector, the upgrade costs and utility savings were allocated to the water, air quality, or energy sector, as appropriate (Table 7.3). If a particular upgrade measure improved both energy and water efficiency (such as the dishwasher), half the cost was allocated to each sector. When broken into a sector analysis, the alternative water efficiency upgrades had a payback period of 6.4 years, while the alternative energy efficiency upgrades had a payback period 21.8 years, more than three times as long. Although the annual savings from the alternative energy upgrades is $\$ 136$ higher compared to the annual savings from the alternative water upgrades, the initial cost of implementing the alternative energy efficiency upgrades is $\$ 3,622$ higher than implementing the alternative water upgrades. This means that alternative water efficiency upgrades are the more cost-effective upgrades, and as a group, out-perform the alternative air quality and energy efficiency upgrade sectors. 


\section{Chapter 8.0 - Comparison of Findings}

This chapter will explore previous findings related to the cost-benefits of greening affordable housing, specifically older, modest-sized existing single-family homes. The sources for comparisons are academic and professional literature, which document the results of reputable non-profit organizations and state weatherization programs. Nonmonetary co-benefits of greening affordable homes, such as improved health, will also be presented.

\section{Non-Profit Organization Case Studies}

Table 8.1 Rehabilitation case studies summary.

\begin{tabular}{|c|c|c|c|c|}
\hline Project Name & $\frac{\text { Green }}{\text { Premium }}$ & $\begin{array}{c}\text { Utility } \\
\text { Savings(\%) }\end{array}$ & Features Upgraded (Indoor only) & $\begin{array}{l}\text { Upgrading } \\
1,000 \text { sq feet }\end{array}$ \\
\hline $\begin{array}{l}\text { Montalvin NSP (CA) } \\
\text { Single Family Homes } \\
\text { Proposed Original } \\
\text { Upgrades }\end{array}$ & $\$ 4.01$ & $28 \%$ & $\begin{array}{l}\text { Energy: bath fans, ceiling insulation, ceiling fans, clothes } \\
\text { washer, dishwasher, indoor and outdoor lighting and } \\
\text { CFLs, refridgerator. Water: faucet aerators, low-flow } \\
\text { showerheads, toilet displacement bags. Air: bamboo } \\
\text { flooring, low-voc paints. }\end{array}$ & $\$ 4,009.88$ \\
\hline $\begin{array}{l}\text { Johnson Creek (OR) - } \\
\text { Condominiums }\end{array}$ & $\$ 7$ & $\begin{array}{l}76 \% \\
\text { (Energy } \\
\text { only) }\end{array}$ & \begin{tabular}{|l|} 
Energy: baseboard heaters, dual pane windows and \\
doors, R-38 ceiling/R-30 floors/R-8 walls insulation, water \\
heaters. Water: aerators, clothes washers, toilet tank \\
disp. bags. Air: bathroom fans, low VOC carpet, \\
Marmoleum flooring, low VOC paint . (Outside: \\
Hardiplank cement siding.)
\end{tabular} & $\$ 7,000.00$ \\
\hline $\begin{array}{l}\text { 20th Street (CA) - } \\
\text { Apartments }\end{array}$ & $\$ 3.61$ & $25 \%$ & $\begin{array}{l}\text { Energy: dual pane windows, insulation: R-30 attic, R-11 } \\
\text { walls, light fixtures and CFLs, programmable } \\
\text { thermostats, repaired/upgraded existing solar water } \\
\text { heater, skilights. Water: Low-flow faucets, showerheads, } \\
\text { toilets. (No air features.) }\end{array}$ & $\$ 3,610.00$ \\
\hline $\begin{array}{l}\text { Columbia Terrace } \\
\text { (MA) Apartments }\end{array}$ & $\$ 1.51$ & $36 \%$ & $\begin{array}{l}\text { Energy: dishwasher, insulated doors, rangehood, } \\
\text { refridgerator, repairs to heating system, lighting and } \\
\text { CFLs. Water: low-flow showerheads, toilets. Air: ceramic } \\
\text { tiles, Marmoleum, low-voc paints. }\end{array}$ & $\$ 1,510.00$ \\
\hline $\begin{array}{l}\text { Woodlawn } \\
\text { Development Assoc. } \\
\text { (IL) - Apartments }\end{array}$ & $\$ 4.74$ & unknown & $\begin{array}{l}\text { Energy: dual pane windows, furnances, insulation: r-18 } \\
\text { walls/R-43 attic rock wall, reflective roof coating, lighting, } \\
\text { photovolatic, weatherstripping, water heaters. Water: } \\
\text { low-flow bath/kitchen fixtures, including showerheads. } \\
\text { Air : Safecoast caulk, Mohawk recycled carpet, low VOC } \\
\text { primer, recycled tile, Low VOC wood finish. (Blower door } \\
\text { test used.) }\end{array}$ & $\$ 4,740.00$ \\
\hline $\begin{array}{l}\text { Positive Match (CA) - } \\
\text { Apartments }\end{array}$ & $\$ 11.55$ & $13 \%$ & $\begin{array}{l}\text { Energy: hydronic (baseboard) heating, refridgerator. (No } \\
\text { water measures.) Air Quality: non-carpet (bamboo, } \\
\text { rubber, cork, tile, (natural) linoleum, and no VOC paint. }\end{array}$ & $\$ 11,550.00$ \\
\hline Average & $\$ 5.68$ & $38 \%$ & $\mathrm{n} / \mathrm{a}$ & $\$ 5,682.00$ \\
\hline
\end{tabular}

Source: Bradshaw et al., 2005. 
Bradshaw et al. present a collection of case studies with analysis of costs and projected benefits. Of the 16 non-profit green affordable housing projects documented, only five involved the upgrading of existing buildings (Bradshaw et al., 2005, p. 41). Of these five rehabilitation projects, and only one upgraded detached dwelling units (Johnson Street in Oregon) (Bradshaw, et al., 2005, p. 98). Additionally, one of these five non-profit projects (Positive Match in California) focused almost exclusively on improving indoor air quality, thus it was somewhat dissimilar to the proposed NSP2 rehabilitations (Bradshaw et al., 2005, p. 127). Nonetheless, while these cases are not precisely comparable to the NSP2 program which improves energy efficiency, water efficiency, and indoor air quality of existing single family homes, these five case studies do provide details on the improvements made, what materials were selected, implementation costs, and expected utility savings.

Table 8.1 presents a summary of the upgraded features, projected utility savings, as well as the green premium. The green premium is the added cost of rehabilitating the dwelling units using green materials and products instead of conventional versions, such as using carpet made from recycled plastic bottles instead of conventional carpet. Due to the fact that dwelling unit sizes varied, for comparison purposes, each was calculated for a 1,000 square foot unit, representing a modest-sized home. On average, across the five case studies, the green premium was $\$ 5.68$ per square foot; had Positive Match (which is an outlier at $\$ 11.55$ per square foot) been excluded, the average green premium would have been $\$ 4.22$ per square foot (Bradshaw et al., 2005, p. 129). According to findings in Table 5.1, Montalvin's original upgrades had a green premium of $\$ 4.01$ per square foot $(\$ 4,463$ divided by 1,113 square feet), matching this almost perfectly. Multiplying the individual project green premiums by 1,000 square feet provided a range of greening modest sized units from $\$ 1,510$ to $\$ 11,550$, with an average of $\$ 5,682$; when Positive Match is excluded, the average per unit upgrade cost is $\$ 4,215$. For the original upgrades, the Montalvin green premium per unit was $\$ 4,463$, which is higher than somewhat higher than the $\$ 4,215$ average of the four more comparable projects. 


\section{Non-Profit Green Upgrades}

Another interesting aspect of the case studies is examining which particular green upgrade measures were included. Most projects (at least three of five) included green upgrades related to the following:

- ceiling or attic insulation

- dual pane windows

- lighting (energy efficient)

- low flow bath/kitchen devices

- low VOC paint

- refrigerator (energy efficient)

- water heater (energy efficient)

One can assume that these particular measures were included at least in part due to project priorities and perceived cost-effectiveness. For example, water saving devices have been shown to have low initial costs and quicker payback period relative to other upgrades (see Table 7.3). Another important note is that many projects reported being able rebates (for instance, for dual windows) that the Montalvin project, run by a local government, did not seem eligible to receive (Bradshaw et. al, 2005, p. 47, 78, 81, 99, 129). In contrast, these four upgrades were used by only one project each:

- insulated doors

- photovoltaic panels

- reflective roof coating

- skylights

The infrequent use of these upgrades suggests these upgrades were perceived to have lower cost-effectiveness. It is useful to note that photovoltaic panels used by one project were partially paid for by the State of Illinois (Bradshaw et al., 2005, p. 153). 


\section{Weatherization Review (Government Program)}

Weatherization is the largest residential energy conservation program in the country, having improved the energy efficiency of approximately 6.3 million homes as of 2010 , and typically upgrading 100,000 homes a year (Reamy and Gates, 2009). The Weatherization Assistance Program (WAP) was established by Congress in 1976 under Title IV of the Energy Conservation and Production Act with a mandate to retrofit the single-family homes, apartments, and mobile homes of low-income households for greater energy efficiency (Kaiser and Pulsipher, 2004). Owner or renter households at or below $200 \%$ of the federal poverty level are eligible, as are those at or below $60 \%$ of state median income; for a family of four in California as of 2010 , this is $\$ 57,291$ annually (Tonn, 2003; Reamy and Gates, 2009; California Community Services and Development Department [CSD], 2007; CSD, 2008). WAP is supported with funding and technical assistance from the US Department of Energy but is implemented by over 900 local government divisions (such as community development departments) and non-profit agencies, typically members of the Community Action Partnership Network (CSD, 2010).

Table 8.2 Rehabilitation case studies summary.

\begin{tabular}{|c|c|c|c|}
\hline Proiect Name & $\frac{\text { Green }}{\text { Premium }}$ & $\begin{array}{l}\text { Utility } \\
\text { Savings(\%) }\end{array}$ & Features Upgraded (Indoor only) \\
\hline WAP Nationwide & $\begin{array}{c}\$ 1,069 \\
\text { per home }\end{array}$ & $23 \%$ & $\begin{array}{l}\text { Energy: caulking, cooling system repairs, furnace repairs, } \\
\text { insulation (attic), light fixtures,shades and screening, } \\
\text { storm windows, weatherstripping. Water: low-flow } \\
\text { showerheads, faucet aerators. (No air quality measures.) }\end{array}$ \\
\hline WAP California & $\begin{array}{c}\$ 2,018 \\
\text { per home }\end{array}$ & $\begin{array}{l}\$ 418 \text { in } \\
\text { energy } \\
\text { savings }\end{array}$ & Energy: appliances, insulation, weatherstripping. \\
\hline $\begin{array}{l}\text { WAP Contra Costa } \\
08-09\end{array}$ & $\begin{array}{c}\$ 3,207 \\
\text { per home }\end{array}$ & unknown & $\begin{array}{l}\text { Energy: caulking, ceiling insulation, lighting and CFLs, } \\
\text { programmable thermostat, refrigerator, water heater. }\end{array}$ \\
\hline Average & $\begin{array}{c}\$ 2,098 \\
\text { per home }\end{array}$ & $\mathrm{n} / \mathrm{a}$ & $\mathrm{n} / \mathrm{a}$ \\
\hline
\end{tabular}

Source: Kaiser and Pulsipher, 2004; Campanella, L., personal communication, January 6, 2010; Reamy and Gates, 2009; California Community Services and Development Department [CSD], 2008. 


\section{Costs and Benefits of Weatherization}

As shown in Table 8.2, WAP agencies typically achieve appreciable energy savings with implementation costs much lower than most of the non-profit case studies or the Montalvin NSP2 proposal. (It should be noted, however, that the scope of WAP is energy efficiency, with limited water efficiency and no air quality enhancement scope.) On a nationwide average, WAP agencies upgrade homes for an average of $\$ 1,069$ (in 2010 dollars) and residents typically save $23 \%$ on their energy bills (Berry and Brown, 1995; Tonn, Schmoyer, and Wagner, 2003). The WAP has an established history of reducing home utility bills at a reasonable cost of implementation. On average, the program returns $\$ 1.65$ in energy related benefits for every $\$ 1$ invested (Reamy and Gates, 2009).

Also shown in Table 8.2, the typical California non-profit or government agency spends $\$ 2,018$ to improve the energy efficiency of a home, saves the residents $\$ 447$ annually (in 2010 dollars), and results in a payback period of under 5 years (CSD, 2009b; CSD, 2007). With a payback period nearly one-fifth of the Montalvin alternative energyrelated upgrades (Table 7.3), the WAP implementation is substantially more cost effective and affordable.

There is great diversity in the methods and energy conservation measures used by organizations implementing weatherization across the US, influenced in part by the housing stock and climate (Brown and Berry, 1995). Thus, it is difficult to definitively describe the average weatherization measures. However, a nationwide, statistically valid study indicated that substantial energy savings could be attributed to the following weatherization measures (Brown and Berry, 1995, p. 734, 736-737) :

- attic and wall insulation

- water heater efficiency upgrades

- furnace replacement

- air sealing (weatherstripping and caulking)

- low-flow showerheads (due to reduced need for hot water) 


\section{Local Weatherization Upgrades}

Contra Costa County government itself provides weatherization services, and according to County records obtained, the cost (labor and materials) to implement weatherization upgrades was an estimated $\$ 3,207$ per dwelling during 2008-2009. Although this figure is higher than the national or state average WAP per dwelling cost, it is still $\$ 7,538$ lower than the $\$ 10,745$ estimated cost of labor and materials for the alternative energy upgrades proposed for the Montalvin NSP2 (Table 7.3). The energy efficiency measures implemented during fiscal year 2008- 2009 by the Contra Costa County WAP (as reported to the State were the following upgrades (Campanella, L. personal communication, January 6, 2010):

- ceiling insulation (R-30)

- caulking

- compact fluorescent lamps

- programmable thermostat

- refrigerator

- water heater replacement

Overall, while the Weatherization Assistance Program is not entirely comparable to the NSP2 green goals, particularly in its omission of improving indoor air quality, the program does offers a model series of affordable upgrades that improve energy and water efficiency. HUD Recommended Upgrades

A 2008 HUD publication recommends particular green building measures moderate rehabilitation (i.e., significant repair and upgrades of dwelling features, but not structural changes) of affordable housing. This manual, Building ENERGY STAR Qualified Homes and Incorporating Energy Efficiency and 'Green' Building Practices into HOME-Funded Affordable Housing, was not referenced in HUD's 2009 NSP2 funding notification, nor does it provide cost estimate ranges, relative costs, or cost-benefit analysis. The manual states 
that although incorporating green building elements into affordable dwelling units reduces operating and maintenance costs for owners and residents, and improves quality of life for residents, it states that jurisdictions "face the challenge of determining which green building practices are feasible and cost-effective...(HUD, 2008, p80)." With the pricing challenge acknowledged, the manual indicates that in most older homes, four elements are responsible for most energy loss: 1) air leakage, 2) poor-functioning heating and cooling systems, 3) insufficient and poorly installed insulation, and 4) inefficient or leaky windows ( $p$. 58). It then promotes the following energy conservation strategies as having low initial implementation costs, or have short payback periods, making them cost effective. These strategies, which begin to address the main causes of energy loss, are as follows (p. 58):

- sealing (caulking) air leaks

- sealing and insulating ducts

- repairing/upgrading combustion equipment

- increasing insulation

- installing programmable thermostats

Interestingly, the HUD manual mentions that some of these upgrades may coincide with existing local Weatherization Assistance Programs (WAP) services, and suggests weatherization may be able to "support" other projects, perhaps through lending subject matter expertise.

Other green energy upgrades discussed in the manual, such as appliances, windows, and water saving devices, were categorized as measures with moderately expensive initial cost and longer payback period. Replacing appliances was recommended if existing appliances were near the end of their expected life or if in poor repair, as this measure is usually a cost-effective in moderate rehabilitation cases, saving up to $\$ 80$ a year in energy costs (p. 20,64). Additionally, Energy Star dishwashers and clothes washers reduce water demand, saving money on water bills. According to the 2008 manual from HUD, replacing 
the five most frequently used light fixtures with Energy Star versions can save about $\$ 65$ each year in energy costs, as compact fluorescent light bulb (CFL) use $75 \%$ less energy incandescent bulbs (p. 20). Installing Energy Star windows can help reduce energy bills up to $15 \%$ according to the HUD manual, depending on geographic location (p. 65). These windows help keep cold air out of the home as well as hinder summer heat transfer from the sun (p. 65). R-value is the capacity of a material to impede heat flow and measure as thermal resistance (p105). Older single pane windows have less than one-tenth of the Rvalue of typical exterior walls, and if loose fitting, damaged, or missing weather stripping, putty, or caulk, these older windows can easily leak. However, the HUD manual notes that replacing all the windows in a property can quickly become expensive, and if the cost is prohibitive, existing windows should be caulked properly to prevent leakages (p. 65).

HUD did not overlook cost-effective water efficiency upgrades, as the manual states that with "simple upgrades" (not specified), households can save about $\$ 170$ per year (p89). WaterSense labeled products (a labeling program of the EPA) were described as appropriate for rehabilitation projects, as these high-efficiency fixtures can reduce standard flow by more than $30 \%$ without sacrificing performance. Specifically, the manual recommends WaterSense labeled high efficiency toilets which use less than 1.3 gallons per flush, and the bathroom sink faucets which use no more than 1.5 gallons per minute (p. 89). While tankless water heating systems (which heat water instantly at the tap) are mentioned specifically as both a way to save water and energy, the cost or cost-effectiveness of these systems is not addressed, thus perhaps this measure can be considered a weak recommendation (p. 89). Another recommended measure is educating residents on how to use their energy equipment effectively and efficiently. Behaviors such as turning out lights in empty rooms and turning off the heating/cooling system when the home is unoccupied are considered important lessons that should be taught to residents to appreciably reduce energy use (p. 47). 


\section{Chapter 9.0 - Co-Benefits of Greening Existing Housing}

Greening existing older homes results in monetary benefits in the form of utility bill savings, as demonstrated with the projections and case studies presented in previous chapters. However, the benefits of green upgrades are not limited to those that are easily monetized. Greening existing building stock, including affordable homes, is anticipated to contribute appreciable improvements in resident health and reduced environmental impacts. In this section, the valuable co-benefits gained by improving the energy and water efficiency of existing housing stock will be briefly explored, including health-related benefits and greenhouse gas emissions reductions.

\section{Health Benefits}

Indoor air pollution is one of the top four environmental health risks identified by the US EPA (Jacobs, Kelly, and Sobolewski, 2007). On average, US citizens spend about $90 \%$ of their time indoors (Jacobs, Kelly, and Sobolewski, 2007). Much of that time is spent at home, thus housing is a key factor in health (Chapman et al., 2009). Chronic exposure to allergens such as dustmites, mold, and pollen is associated with asthma, and a growing body of evidence suggests that allergens and other chemicals in the home contribute to both sensitizing children and triggering attacks (Jacobs, Kelly, and Sobolewski, 2007). One recommendation from health organizations is to improve indoor air quality by removing carpet (Agency for Toxic Substances and Disease Registry, 2007). In practice, many organizations performing green upgrades replaced carpet with fiber-free flooring (such as bamboo or natural linoleum) as a green upgrade, and took additional precautions by avoiding VOCs (volatile organic compounds) in paint, stains, and finishing materials (Bradshaw et al., 2005, p. 127). Non-profits "identified improved health of residents such as reduced exposure to toxics and reduced incidence of asthma" from to these upgrades, as documented in Bradshaw et al., 2005, (p. 37). 
In other instances, health benefits result from more easily achieved indoor warmth. The general effect of greater warmth and dryness is improved respiratory health (Chapman et al., 2009). Heat retention and draft reduction can be accomplished through greening measures such as insulation, weatherstripping, and caulking, which reduce the amount of energy required to maintain a given indoor/outdoor temperature difference (Milne and Boadman, 2000). One study found a $38 \%$ reduction in overnight hospital stays of residents 65 years and older whose homes had been better insulated (Chapman, 2009, p. 274).

\section{Environmental Benefits}

Higher energy efficiency reduces demand for electricity, in turn reducing environmental impacts of electricity generated with fossil fuels such as coal. Fossil fuels (coal, oil, and natural gas) are the principal fuels of electricity generation in the United States, largely due to their low costs and ready availability of coal (EPA, 2010e). As of $2010,48 \%$ of US power was generated with coal (Hong and Stlatick, 1994; Lomax , 2010). Reduced coal mining due to lower electricity demand would result in less impact to landscapes from coal mining and reduced incidence of acid rain and poor air quality in the vicinity of the coal-fired power plants. Mining degrades water quality when the zinc, sodium, selenium, sulfate it unearths washes into streams (EPA, 2010f). Mountaintop removal mining, which impacts 12 million acres in the Appalachian region of the US, could also be reduced with higher energy efficiency (EPA, 2010f). Mountaintop removal mining a coal extraction method which denudes vast areas of landscapes rock to expose seams of coal by removing all vegetation, layers and dirt, thereby causing considerable habitat and wildlife loss (EPA, 2010f; EPA $2010 \mathrm{~g}$ ). Acid rain is another affect of energy generation, occurring when sulfur dioxide and nitrogen oxides from burning fossil fuels such as coal react with water, oxygen, and fall to the earth, causing acidification of lakes and streams, damaging trees, crops, and even historic monuments (EPA, 2008b). Coal- and oil-fired power plants and industry are also the largest sources of sulfur dioxide, which at high concentrations, reduce air quality and 
aggravate existing conditions of sensitive individuals with asthma, bronchitis, and emphysema (especially children and the elderly) (EPA, 2010e).

Environmental Benefits - Greenhouse Gas Reduction

North America is susceptible to most of the serious threats of climate change, such as sea level rise, precipitation and temperature regime change, increased fires and droughts, and severe storms (Henson, 2008). Some of these changes are already being seen. For instance, there has been "a clear ramp-up in precipitation intensity for the US, especially since 1970s (Henson, 2008, p. 59)." Of all greenhouse gases, carbon dioxide is the most abundant in the atmosphere, and has increased $40 \%$ from pre-Industrial Revolution concentrations (Henson, 2008, p. 25). Failing to curb emissions to lessen climate change will lead to more severe consequences for people and property.

In the United States, electricity production is the single largest source of carbon dioxide emissions, representing $41 \%$ of all carbon dioxide emissions (EPA, 2010h). The majority of US electricity generation has historically been from coal, and as of 2010 , coal was burned to generate $48 \%$ of US electricity (Hong, and Stlatick,1994; Lomax, 2010). Coal-fired power plants generally cause more pollution, such as sulfur dioxide and nitrous oxides, per unit of electricity than any other fuel. In addition, combustion of coal for energy generation contributes significantly to climate change because every 1 pound of coal completely combusted produces 2.86 pounds of carbon dioxide (Hong and Stlatick,1994). The importance of reducing GHG emission and their direct relationship to energy is explained as follows:

Emissions of greenhouse gases must be curtailed if we hope to minimize the extent and impact of climate change. The majority of GHG emissions come from combustion of fossil fuels for energy and transportation." (CAPCOA [California Air Pollution Control Officers Association], 2009, p. 1). 
Reducing energy demand through improving the energy efficiency of homes, as explored in this project, has climate change co-benefits. The EPA estimates that, for example, if home energy usage across the US were reduced by $10 \%$, at least 40 power plants would be unneeded, and the resulting carbon emissions reduction would be equivalent to removing 25 million vehicles from the roads (Partnerships for Home Energy Efficiency, 2007).

Case studies of greened affordable housing were projected to use between $13 \%$ to $76 \%$ less energy than prior to upgrades, with an average of $30 \%$ in energy savings across nonprofit projects and federally-funded weatherization projects (see Table 8.1 and Table 8.2). This finding indicates that the $10 \%$ energy reduction per dwelling target is theoretically achievable.

\section{Environmental Benefits - Water Conservation}

Beyond the demonstrated direct monetary benefits to the resident, reducing water consumption by retrofitting water fixtures of existing homes has positive repercussions for the environment and society. The environmental and societal benefits gained through water conservation stem from avoiding construction of new dams and from slowing or halting increases in water diversion, thereby preserving high quality habitat for fish, birds, and other wildlife, and saving hundreds of millions of public dollars for other uses (EPA, 2010i).

In California, surface water (typically from rivers) makes up $61-79 \%$ of water used for agriculture and urban purposes in a given year, averaging 75 acre feet in a wet year (California Legislative Analyst Office [CaLAO], 2008). (In contrast, ground water comprises up to $21-39 \%$ of the state water supply, averaging 41 acre feet in a dry year [CaLAO, 2008].) River systems are obviously essential habitat for fish and life forms that live within the water itself (aquatic habitat), but they are also essential to numerous wildlife species dependant upon the vegetation developed at the edges (riparian habitat). A river's riparian floodplain, freshwater wetlands, and oak forests are some of the most productive and diverse habitats and can support hundreds of migratory bird species and other wildlife (The Nature Conservancy, 2010). 
Dams are barriers constructed, by intention, to change natural flow rates of rivers to store water for release at will. Dams spoil the integrity of riparian and aquatic habitat. The stored water inundates the upstream area, completely eliminating large areas of mature, intact riparian forest and wetlands, and causes a build up sediment behind the barrier. Meanwhile lower reaches experience rises in temperature, reduction in dissolved oxygen, and changes in chemistry $(\mathrm{pH})$ that leads to changes in food webs and reduced biodiversity (West Virginia Conservation Agency [WVCA], 2003). Perhaps most dramatically, dams cut salmon and other migrating fish off from their native spawning grounds and reduce egg viability, decimating commercially and recreationally important fish populations (Moyle, Israel, and Purdy, 2008, p. 27, 50, and 64). From a societal benefit perspective, development and operation of additional surface water (or ground water) supplies costs hundreds of millions of public dollars that could be spent on many other important public services. Dams also increase the need to construct additional water supply treatment and wastewater facilities (Utah Division of Water Resources, n.d).

Water conservation eliminates waste and curtails the need for increased water diversion of rivers already modified with dams. It also makes new dams on the few remaining wild rivers unnecessary. Damming and diversion have severely degraded most California rivers, and only one river, the Cosumnes River, remains undammed on the California side of the Sierra Nevada (Center for Watershed Science, 2010; The Nature Conservancy, 2010). Other unique California natural monuments, such as Mono Lake, have been devastated by water diversions which drastically affected its ecology (Mono Lake Committee, 2010; The Nature Conservancy, 2010; The Trailmaster, 2007; Knudson, 2010).

Low-flow devices are an important component of an indoor water conservation program, stretching existing supplies of water farther by lowering the flow rate at bath and kitchen faucets, toilets, showerheads, while still satisfying the needs current users (West Virginia Conservation Agency [WVCA], 2003). Water conservation on a mass scale is possible and 
can be highly successful. Conservation has made it possible for the city of Los Angeles to grow by 1 million people since the 1970s, but not increase its water usage (LADWP, 2010). During periods of drought, which are more likely to occur with climate change, meeting minimal needs of all users (urban, agriculture, and wildlife) will be very difficult (Henson, 2008, p.13, 69; WVCA, 2003). Eliminating waste and reducing excessive use should be a central main water management goal, and an important component of this effort should be installation of household water conservation devices.

\section{Value of Co-benefits}

Researchers Schweitzer and Tonn have attempted to quantify the health, safety, and indirect environmental benefits accrued from weatherization (Schweitzer and Tonn, 2003). According to their 2003 study, each weatherized household experiences an additional net present value of $\$ 156$ (2010 dollars, total for 30 years) in health and safety benefits due to decreased illnesses and risk of fires (due to combustion equipment repair or replacement). When less electricity is generated and consumers burn less natural gas, the environmental benefit is improved air quality from less particulate matter and heavy metals released into the air. Schweitzer and Tonn valued these air quality benefits at $\$ 500$ (2010 dollars, for 30 years) per weatherized home. Another interesting figure was the estimated value of low-flow showerheads and faucet aerators, commonly provided alongside weatherization service, provided an estimated net present value of $\$ 336$ alone (2010 dollars) per weatherized household (2003, p. 327).

California law now mandates that Greenhouse gas emissions must be reduced in accordance with AB 32 (2006), as a mitigation measure for climate change. The researchers monetized the avoided greenhouse gas emissions at $\$ 1,577$ (2010 dollars, for 30 years) per weatherized dwelling from reduced electricity generation and natural gas combustion. As shown in Chapter 7 in Table 7.2, this study found that the alternative upgrades would deliver a projected annual savings of 2,728 pounds of carbon annually. This savings would occur for an upfront cost of $\$ 10,745.27$, which is a cost of $\$ 1$ per pound for 4 years, and subsequent annual savings would be incurred at no cost. 


\section{Chapter 10.0 - Policy Implications}

The final chapter of this study reflects on the preceding cost-benefit analysis findings and commentary from researchers in affordable housing to evaluate the policy of greening affordable homes. The evaluation specifically addresses the new HUD policy of adding green upgrades to homes rehabilitated and sold as affordable single-family homes through the second iteration of the Neighborhood Stabilization Program, NSP2. It also discusses how HUD could improve its greening guidance in its future notifications. The chapter concludes with an assessment of particular greening strategies and objectives, and offers recommendations for formulating cost-effective green upgrade programs in the future.

\section{General Principles}

Most low-income people live in older, drafty homes with little insulation that were built during the 'cheap energy era' (Brown and Berry, 1995). This is evidenced by the fact that $39 \%$ of the homes repaired through the weatherization program (from inception until 2005) were built before 1955. Even California state government, considered a leader in environmental regulations, did not include energy efficiency standards in its building code (Title 24, Part 6) until 1978. By this point, 65\% percent of US housing stock that existed in 2009 had already been built (Brown and Berry 1995; Census, 2008, p. 1;EDAW, 2008) ${ }^{3}$. While many pre-Title 24 homes in California and elsewhere wasted energy from the time of first commissioning, "invariably" aging makes these structures even more cold, inefficient, and more expensive to heat (Brown and Berry, 1995).

Until recently, green building features were not typically incorporated into affordable housing, as these features are associated with high cost (Stawitz et al.. 2008; Bradshaw et al., 2005, p. 9). However, utility bills typically comprise a much larger percentage of household budgets for lower-income families; low-income households typically spend $17 \%$ of their total

\footnotetext{
${ }^{3}$ Also of 2009, the median aged housing unit in the US was built in 1974 (US Census Bureau, 2010).
} 
income on energy compared to $4 \%$ for other households (Reamy and Gates, 2009). It is not unheard of for some low-income households to face the hardships of choosing between heat and other basic necessities (Brown and Berry, 1995). Thus despite the higher upfront cost, investment in green features immediately reduces utility usage and results in long-term savings, which has a greater relative benefit to low-income households than to mid- and high-income households.

There are several meaningful co-benefits to green affordable housing, including a tighter building envelope that creates more warmth using less energy, and thereby makes indoor comfort less expensive. Lowering the energy and water demands of a home through green upgrades also reduces a household's vulnerability to increases in energy and water prices (Gether et al., 2005 in Sunikka, 2006). Greening existing homes also meets the dual environmental goals of increased water and energy conservation. By saving energy, retrofitted homes decrease carbon dioxide emissions to the environment and lessen one of the central causes of global warming, a very serious threat to all parts of the world (Foster, Tramba, and MacDonald 2008). A significant proportion of carbon dioxide emissions reduction policies in developed countries target only new buildings, and government bodies have to date done little to upgrade existing buildings (Sunikka, 2006, p. 522). Greening of existing affordable housing is one important policy step that addresses this key sector. Greening may also include indoor air quality improvement measures, for instance replacing carpets with natural, renewable, low-VOC, non-allergen accumulating flooring such as natural linoleum or renewable bamboo. These measures are believed to improve health, particularly of those with respiratory ailments. (Health and the environmental co-benefits of green upgrades are discussed in Chapter 9.)

Due to the short and long-term benefits to low-income residents and the environment, the greening of affordable housing through the NSP2 program is both merited and endorsed. By allocating budget dollars towards greening project homes, a tradeoff is made. Greening 
adds an additional cost per home, thereby reducing the total number of homes that can be made available through the NSP2 program. However, based on this study and other cases, operating costs of the green homes are likely to be $20 \%$ to $40 \%$ lower for the residents, helping which helps improve affordability. The green features also allow for affordable warmth, which may mean fewer respiratory illnesses and potentially fewer asthma attacks, benefiting the household with better health, another valuable benefit enjoyed. The environmental benefits are also immediate, which includes lower demand for water and electricity, which means a decelerated demand for additional dams and fossil fuel extraction, which means decelerated destruction of habitat and reduced carbon dioxide emissions. Further, the social benefit is multiplied if the labor to conduct the green the units is provided in part by apprentices in workforce development programs (for the work that does not require a licensed electrician, such as installing clotheslines and showerheads), creating green jobs and providing training. Greening affordable housing essentially generates multiple benefits from the same tax dollar, and was thereby a sensible addition to the Neighborhood Stabilization Program.

\section{Limited Data}

While the social objectives behind green affordable housing are not likely to be controversial, two significant obstacles to widespread incorporation of green building features into affordable housing has been lack of has been upfront cost and long-term savings data for implementation (Bradshaw et al., 2005, p. 172). In searching for documented cases of affordable housing improved with green upgrades, few case studies could be found. The best resource discovered was Bradshaw et al.'s 2005 collection of case studies which documented 16 projects which provided housing for households earning between $80 \%-120 \%$ of area median income, at a cost of less than $30 \%$ of their income (in compliance with HUD's affordability definition) (Bradshaw et al., 2005, p. 16). However, only five of Bradshaw et al.'s cases were rehabilitation projects (not newly built housing units), 
thus only those five were relevant to the NSP2 upgrade efforts. And of these five projects, only Johnson Street in Oregon units were detached greened existing affordable dwelling units, making this project the most comparable to NSP2 efforts to rehabilitate existing singlefamily homes (Bradshaw et al., 2005, p. 41). (Review of these cases is provided in Chapter 8.) Within this larger context of limited data on greening of existing affordable homes, the value of the hypothetical Montalvin case study created for this study—based on genuine floor plans and redevelopment planner insight-is put in perspective.

Alternative Set of Upgrades Found Superior

Another significant obstruction to non-profit groups and government agencies incorporating green features into affordable housing has been the lack of clear guidance as to which specific green building upgrade measures are financially feasible under tight budgets, and ultimately most cost-effective (HUD, 2008, p. 80). The Contra Costa County planners formulating the NSP2 grant proposal/application struggled with a lack of clear direction on which specific green measures would be affordable and cost effective. The original upgrade set, devised under the aforementioned circumstances of limited cost and benefit data, were found in this study to cost over $60 \%$ more than anticipated $(\$ 24,501$ instead of $\$ 15,000$ ), and were determined to include some features (specifically dual pane windows) which green building professionals and research literature regard as lowerperforming and less cost effective than alternatives (specifically ceiling insulation) (Di Santo, T., personal communication, April 9, 2010; HUD, 2008, p. 62; Brown and Berry, 1995, p. 729). If the original upgrades had been implemented as proposed, this difference of $\$ 9,501$ in the budget would have meant a reduced cap on the home purchase price to $\$ 126,749$, or a financial assistance package reduced by the same amount. The financial assistance package (typically a grant for qualifying households) is an important component in making homeownership financially feasible for first-time or low-income households by 
lowering or eliminating down payment and mortgage closing costs (Darrensburg, L. personal communication, July 3, 2009).

The alternative set of upgrades created for this study were formulated to meet the NSP2 objectives, but aimed to do so at a lower cost (see Appendix 2 for a detailed product listing). The alternative set was estimated to cost $\$ 4,133.50$ less upfront than the original upgrades at $\$ 20,367$, and to save the household an additional $\$ 223$ than the original upgrades. This brought annual household utility savings to $\$ 740$ over the baseline home, reducing utility costs by $28 \%$. Thus the alternative upgrades were superior in cost-effectiveness overall, and future upgrade programs upgrade measures should more closely resemble the alternative set of measures than the original upgrades set. Details of the alternative upgrades are described in Chapters 6 and 7.

\section{Cost-Effective Upgrade Measures}

The following provides recommendations to planners and others for formulating a costeffective set of greening measures for exiting homes, based on findings from the Montalvin theoretical case study. The NSP2 green upgrade measures were intended to address three areas (or sectors) of greening: indoor air quality, water conservation, and energy conservation. Between the two sets of upgrades analyzed, the alternative green upgrades performed better than the original upgrades, as a whole. (Details of the alternative upgrades are in Appendix 2.) Within this group of alternative upgrades, some measures performing better than others. When broken up across to these sectors and analyzed for costs and benefits, the payback rates for the alternative upgrades were found to be significantly different for water, energy, and air quality sectors. As shown in Chapter 7, Table 7.3, the alternative water conservation upgrades were estimated to have the shortest payback period, paying for themselves in approximately 6.4 years through utility savings. This is significantly shorter than the 21.8 years for the alternative energy upgrades. The shorter payback for the water conservation upgrades period was mostly due to their lower upfront 
costs. The quick payback period of the water upgrades makes them the "low hanging fruit" of green home retrofitting - a colloquial phrase for easily achieved goals. Conversely, the alternative energy upgrades took decades to payback and had an upfront cost of $\$ 9,557$. This cost is nearly three times higher the federal weatherization work done in Contra Costa County, priced at $\$ 3,500$ for fiscal year 2008-2009 (see Chapter 8, Table 8.2). Coupled with the fact that weatherization upgrades save participating California homeowners $\$ 418$ annually in energy savings, these figures clearly indicate that techniques and upgrade measures used by the weatherization program are more cost-effective, and thus superior to the alternative energy upgrades (see Chapter 8, Table 8.2). Therefore future green retrofitting programs should model their energy efficiency measures closely after the federal weatherization program approach, and not those of either the original or alternative upgrade sets explored in this study.

The two air quality improvement measures studied as a part of the original and alternative upgrades were 1) painting all surfaces with zero-VOC paint, and 2) replacing existing flooring (including carpet) with quickly renewable natural bamboo. These were two of the costliest individual upgrade measures, and compounded by the fact they are not directly associated with any monetary savings, their cost-effectiveness is uncertain. These indoor air quality upgrades are presumed to provide health benefits (see Chapter 9) especially for children with asthma and others with various respiratory conditions, which is particularly important among lower income neighborhoods near industrial plants and freeways (Kleffman and Bohan, 2010). Due to the cost constraints typical of affordable housing endeavors, and limited data, a search for equally or more effective but less costly materials is recommended. If this proves difficult, then perhaps use of VOC concentration tests, such as canister air collection analysis offered by Closer Look Inspections, coupled with a scientifically-established threshold concentration of concern should be used to determine whether the replacement is appropriate or unnecessary (Closer Look Inspections, 
2010). Of course, in the instance that residents suffer from respiratory illness or compromised immune systems, or the homes are located in areas with poor air quality, then regardless of relatively high prices, upgrades that improve indoor air quality are warranted. Improving HUD Greening Guidance

The preceding recommends specific measures as cost-effective green upgrades appropriate for formulating a low-cost home greening program. HUD could improve its greening guidance by promoting those particular upgrades and providing . In addition to promoting the aforementioned cost-effective upgrades, HUD could improve its greening guidance with leadership on four specific issues not addressed by the NSP2 notification. These four issues are:

1) incorporating weatherization methods

2) involving workforce development organizations in project labor

3) providing guidance and pre-negotiation for rebates and tax credits

4) incorporating affordable rentals

Providing direction and leadership on these issues could have aided organizations in formulating their approach to the NSP2 green element, and could have widened the beneficial social impacts of the program for the reasons are provided.

\section{Weatherization Methods}

Weatherization is a federal program of the US Department of Energy with a documented history of affordably increasing the energy efficiency of homes. (See Chapter 8 for greater detail.) Its methods and institutional knowledge in strategically upgrading homes would be an ideal resource to couple with HUD programs such as NSP which seek to improve the energy efficiency of existing homes. In future programs, HUD should encourage jurisdictions to incorporate input from local or state weatherization agencies on how to approach the energy saving upgrades. This takes advantage of decades of local expertise, which would be superior to simply referencing documents that describe or list upgrades but lack information on efficacy or cost guidance. 


\section{Workforce Development Agreements}

Labor was determined to comprise half to two-thirds of the cost to implement the series of upgrades for the home model in this study. Once again, weatherization offers a costeffective, low-cost method. In many instances, weatherization is implemented by Community Action Partnership Network members and other groups which provide workforce development program for those seeking new job skills (California Department of Community Service and Development [CSD], 2010; Community Action Partnership Network, n.d.). Contracting labor through these job skill programs to provide a portion of greening labor would mean a reduced labor cost for appropriate greening tasks, such as installing clotheslines and faucet aerators. By using workforce development program labor, future HUD-funded greening programs will have reduced labor costs. These savings could be allocated towards greening measures that might not have been possible under the tighter budget constraints, such as planting fruit or shade trees, creating raised vegetable beds of clean soil, or simply serving additional households. By encouraging involvement of workforce development programs in future greening projects, HUD would help facilitate a wider distribution of jobs. HUD would be seizing the opportunity to multiply the social benefit potential of federal grant dollars by providing work to not only established contractors and subcontractors, but also to those training for new careers. In future programs, It would be important for HUD to advise jurisdictions to create work agreements that clearly differentiate between "low skilled work" such as installing clotheslines and aerators, from work that should only be done by licensed electricians, such as wiring and replacing lighting fixtures. Also, to create an incentive to arrange labor though workforce development organizations, future HUD programs should award additional ranking points to jurisdictions that commit to making work available to workforce development organizations. ${ }^{4}$

\footnotetext{
${ }^{4}$ In competitive grant competition such as HUD's NSP2, applicants with the highest number of ranking points earn funding.
} 


\section{Rebate Guidance}

Numerous entities providing green affordable housing documented in Bradshaw et al. reported that rebates and tax credits from utility companies, the federal Energy Star program, and other sources provided a portion of project funding (Bradshaw et al., 2005, p. 174, 175). These credits and rebates were earned on a wide range of green measures from appliances to ceiling insulation and windows. Community development corporations (CDCs) in the Seattle, Portland, Boston, and southern California metro areas that developed green affordable housing were able to take advantage these tax and rebate benefits. However, the Santa Clara and Contra Costa County public affordable housing agencies indicated they were not attempting to use efficiency-related tax credits or rebates for their NSP2 programs, despite the fact that these agencies had the capacity to use traditional affordable tax credits (LIHTC) (Lachman, D., personal communication, May 24, 2010). In making phone calls and searching websites, it was found that eligibility and redemption terms for rebates and tax credits for public agencies could not be readily determined for rebates or tax credits of either the federal Energy Star program or the PGE corporation. (Only the local water provided, EBMUD, readily agreed to provide water saving devices to any County employee bearing a title for a home in their service area and their employee identification badge.)

Due to the potential for rebates and tax credits to produce savings that can fund pursuit of additional green upgrades (such as photovoltaic panels), these financial tools should not be disregarded. Two potential solutions are as follows. Ahead of rollout of greening programs such as NSP, HUD could collaborate with the DoE Energy Star division and/or the IRS to create a central resource (i.e., website) that aims to provide enough guidance for those with experience in low-income housing tax credits (LIHTC), such as housing authorities, to be able to apply for Energy Star credits. A parallel recommendation is for HUD 
to assign state departments of housing the responsibility to pre-negotiate rebate terms with the largest energy utilities in the state, on behalf of housing authorities state wide. For instance, HCD in California would pre-negotiate rebate terms with PG\&E and Southern California Edison, and local jurisdictions seeking rebates would have clear forms and instructions.

Incorporating Affordable Rentals

Finally, any policy recommendations for HUD would be remiss if it they did not include commentary on homeownership. Home ownership has been the central affordable housing solution for most of the past decade (Mallarch, 2009). HUD's NSP2 and other ownership-focused programs provide for-sale units, which address the needs of households in certain income ranges (near $80 \%$ of area media income)-households with income low enough to qualify for assistance, but not so low that they cannot afford mortgage payments. However, homes for purchase do little to address one of the greatest affordable housing problems of the US-the limited supply of new, modest, affordable rental housing, like garden apartments of the 50s and 60s (Mallarch, 2009). As stated by affordable housing specialist Alan Mallarch, "[h]ome ownership for lower income people is an inherently risky proposition." Homeownership is not the panacea for all households facing the affordable housing struggle, as demonstrated by the waves of foreclosures associated with the Great Recession, beginning in year 2007. There are merits to homeownership, perhaps chief among them that lower-income homeowners are spared the victimized by "slumlords," as the lower-income owners have the opportunity to take charge of their home's condition. Another important benefit of ownership is that mortgage payments earn the lower-income owners equity that is 
forfeited in rent payments. However, there are a number of benefits to renting not found in ownership:

- lower monthly payments than mortgages (typically)

- can afford to rent in a wider range of neighborhoods than can buy into

- can more easily adapt with changing financial or life situation (moving to a larger or smaller unit, another complex or neighborhood)

- can move closer to a job site to shorten commute length, saving time and fuel

- can take advantage better rental opportunities if they arise

- landlords are responsible for unit repairs, and sometimes utilities and/or laundry machines

In fact, to meet the HUD affordability requirement to serve low-income populations at $50 \%$ area median income (AMI), Contra Costa County added apartment rentals/leases to the proposal, otherwise it faced the slim proposition of being able to serve families in the lowest income categories with purchased housing (CCC, 2009, p. 22, 24). Hence, planners in the field recognize that the homeownership approach falls short in accommodating the poorest families. This study encourages HUD to recommit to closing this critical gap by renewing its role with policies that expand its facilitation of construction and rehabilitation of modest apartment complexes. 


\section{REFERENCES}

Alliance For Water Efficiency (2010). Toilet retrofit devices introduction. Retrieved August 12, 2010 from: http://www.allianceforwaterefficiency.org/Toilet_Retrofit_Devices.aspx

Agency for Toxic Substances and Disease Registry (ATSDR) (2007). Case studies in environmental medicine (csem): environmental triggers of asthma. Retrieved July 29, 2010 from: http://www.atsdr.cdc.gov/csem/asthma/envfactors.html

Best Buy (2007). Guides and Resources: Washer buying guide. Retrieved May 23, 2010 from:

http://www.bestbuy.com/site/olspage.jsp?guidelD=1043363100291\&type=page \&id=c at12077

Bradshaw, W., Connelly, E. F., Cook, M.F., Goldstein, J., and Pauly, J. (2005). The costs and benefits of green affordable housing. Retrieved February 5, 2010 from: http://www.housingtrustonline.org/download/GreenAffordableHousing.pdf

Brown, M. A. and Berry, L. G. (1995).Determinants of program effectiveness: results of the national weatherization evaluation. Energy, 20 (8):729-743

BuilditGreen (2007). Greenpoint Rated existing home checklist v1.2 [Spreadsheet]. Retrieved June 13, 2009 from: http://www.builditgreen.org/guidelines--checklists/

California Air Pollution Control Officers Association(CAPCOA) (2009). Model Policies for Greenhouse gases in general plans.. Retrieved May 23, 2010 from: http://www.cailg.org/sites/ilgbackup.org/files/resources/CAPCOA_Model_Policies_for_Greenhouse _Gases_in_General_Plans_-_June_2009.pdf

California Department of Community Service and Development (CSD) (2007). Income Guidelines for the Low-Income Home Energy Assistance Program (LIHEAP). Retrieved August 14, 2010 from: http://www.csd.ca.gov/Programs/EnergylncomeGuidelines.aspx

California Department of Community Service and Development (CSD) (2008). CSD Helps low-income families manage and reduce enegy costs. Retrieved August 14, 2010 from: http://www.csd.ca.gov/Contractors/documents/Energy\%20tab/LIHEAPDOE\%20Fact\%20Sheet\%20(2008).pdf

California Department of Community Service and Development (CSD) (2010). Weatherization Assistance Program for Low-Income Persons:2009 State Plan and Application to the Department of Energy. Retrieved June 12, 2010 from: http://www.csd.ca.gov/Contractors/documents/Energy\%20tab/State\%20Plans/2009 \%20DOE\%20Standard\%20State\%20Plan\%20rev\%206\%2016.pdf

California Energy Commission (2006). Consumer energy center: Thermostats. Retrieved July 22, 2010 from:

http://www.consumerenergycenter.org/home/heating_cooling/thermostats.html 
California Energy Commission (2010a). Consumer energy center: Water Heaters. Retrieved July 22, 2010 from:

http://www.consumerenergycenter.org/home/appliances/dryers.html

California Energy Commission (2010b). Consumer energy center: Water Heaters. Retrieved July 22, 2010 from:

http://www.consumerenergycenter.org/home/appliances/waterheaters.html

California Legislative Analyst Office [CaLAO] (2008). California's Water: An LAO Primer.

Retrieved July 27, 2010 from:

http://www.lao.ca.gov/2008/rsrc/water_primer/water_primer_102208.aspx

Campanella, L. Annual accounting reports for Contra Costa. July 1, 2008 to June 30, 2009.

Personal communication, California Department of Community Services \&

Development, Energy and Environmental Services Division.

Center for Watershed Sciences (2010). Watershed restoration. Retrieved July 30, 2010 from: http://watershed.ucdavis.edu/research/restoration.html

CFBT-US, LLC. (n.d.). Contra Costa County LODD. Retrieved May 9, 2010 from: http://cfbt-us.com/wordpress/?p=497

Chapman, R., Howden-Chapman, P., Viggers, H., O'dea, D., and Kennedy, M. (2009). Retrofitting houses with insulation: a cost-benefit analysis of randomised community trial. Journal Of Epidemiological Community Health, 63:271-277

City of Roseville (n.d.). HET Toilet rebate application (Form \# 08433-2). Retrieved from: http://www.roseville.ca.us/civica/filebank/blobdload.asp?BlobID=11672

City of Tampa (2010). Water use calculator [Online calculator]. Retrieved April 26, 2010. http://www.tampagov.net/dept_water/information_resources/Saving_water/Water_us e_calculator.asp

Closer Look inspection Group, LLC. (2010). What Are VOCs? Retrieved July 22, 2010 from: http://www.closerlookinspection.com/vocs.htm

Community Action Partnership Network, (n.d). About CAAS. Retrieved August 5, 2010 from:_http://www.communityactionpartnership.com/index.php?option=com_content\&t ask $=$ view\&id $=21 \&$ ltemid $=50$

Contra Costa Consortium (CCC) (2009). HUD Neighborhood Stabilization Program 2 Application (Application ID \# 388071984).

EBMUD (n.d.). Water rates and service charges effective July 1, 2010. Retrieved July 20, 2010 from http://www.ebmud.com/for-customers/account-information/water-ratesservice-charges

EDAW (2008). Case Study: California Title 24 energy code. Retrieved June 13, 2010 from:_http://www.cityofseattle.net/environment/documents/GBTF_NewBldg_Title24_ Case_Study.pdf 
Efficiency Partnership (2010a). Flex your power. product guides. Retrieved July 12, 2010 from: http://www.fypower.org/res/tools/products_results.html?id=100160

Efficiency Partnership (2010c). Flex your power: water heaters. Retrieved August 15, 2010 from: http://www.fypower.org/res/tools/products_results.html?id=100215

Efficiency Partnership (2010b). Energy saving tips: free and low cost recommendations. Retrieved May 29, 2010 from: http://www.fypower.org/res/tools/energy_tips.html

Efloors.com (n.d). How much laminate flooring will you need? Retrieved March 29, 2010 from: http://www.efloors.com/laminate_flooring_estimating.asp

Energy Star (n.d.a). How a product earns the energy star label. Retrieved July 30, 2010 from: http://www.energystar.gov/index.cfm?c=products.pr_how_earn

Energy Star (n.d.b) Ceiling fan basics. Retrieved July 14, 2010 from: http://www.energystar.gov/index.cfm?c=ceiling_fans.pr_ceiling_fans_basics

Energy Star (n.d.c). What about clothes dryers? Retrieved July 9, 2010 from: http://energystar.custhelp.com/cgibin/energystar.cfg/php/enduser/std_adp.php?p_faq id=2984\&p_created $=1171989382$

Energy Star (n.d.d). water heater, high efficiency gas storage for consumers. Retrieved July 10, 2010 from:

http://www.energystar.gov/index.cfm?fuseaction=find_a_product.showProductGroup \&pgw_code=WGS

Enterprise (2008). Green single family rehabilitation specifications. Retrieved June 13, 2009 from:

http://www.greencommunitiesonline.org/tools/resources/green_rehab_specs_gci_20 08_criteria_final.pdf

Foster, S. C., Tramba, A.V., and MacDonald, L.J. (2008). ecoMOD: analyzing energy efficiency in affordable housing. Proceedings of the 2008 Systems and Information Engineering Design Symposium. Charlottesville: University of Virginia.

Henson, R. (2008). The rough guide to climate change. New York: Rough Guides (Distributed by Penguin Books)

Home Depot (2010). Buying guide: refrigerators. Retrieved May 5, 2010 from:http://www.homedepot.com/webapp/wcs/stores/servlet/ContentView?pn=Refrig erators\&langld $=1 \&$ storeld $=10051$ \&catalog $\mid d=10053 \&$ locStoreNum $=1017 \&$ market ID $=$ 21

Hong, B.D., and Stlatick, E.R. (1994, January-April). Carbon dioxide emission factors for coal. Quarterly Coal Report, 1-8. Retrieved July 18, 2010 from: http://www.eia.doe.gov/cneaf/coal/quarterly/co2_article/co2.html

Investopedia ULC. (2010) Dollartimes: the net present value (npv) calculator [Online calculator]. Retrieved June 27, 2010 from:

http://www.investopedia.com/calculator/NetPresentValue.aspx 
Jacobs, D.E., Kelly, T., and Sobolewski, J. (2007). Linking public health, housing, and indoor environmental policy: successes and challenges at the local and federal agencies in the United States. Environmental Health Perspectives, 115 (6): 976-982

Kaiser, M.J., and Pulsipher, A.G. (2004) WAP explained. Energy Policy, 32: 1843-1860

Kleffman, S. and Bohan, S. (2010, January 26). Day II: Health problems persist when options are limited. East Bay ZIP codes lacking middle-class amenities have higher rates of asthma, heart disease and cancer. Contra Costa Times. Retrieved August 1, 2010 from:http://www.contracostatimes.com/top-stories/ci_13919582

Knudson, T. (2010, April 4). The public eye: Mono Lake's unhealthy dust. The Sacramento Bee. Retrieved July 28, 2010 from:

http://www.sacbee.com/2010/03/11/2598405/public-eye-mono-lakes-unhealthy.html

Lawrence Berkeley National Laboratories (LBNL). (2010). Home Energy Savings [Online calculator]. Retrieved June 12, 2010 from: http://hes.lbl.gov/consumer/

Lemus, G. (2006). Montalvin Manor redevelopment area: staff study for the purpose of creating an amnesty program for undocumented construction. Martinez: Contra Costa County.

Lomax, S. (2010, July 16). Climate bill would reduce U.S. GDP by $\$ 452$ billion, energy department says. Bloomberg. Retrieved August 2, 2010 from:

http://www.bloomberg.com/news/2010-07-16/climate-bill-would-reduce-u-s-gdp-by452-billion-energy-department-says.html

Los Angeles Department of Water and Power. (LAWPD) (2010, April 13). LADWP Applauds its Customers February Marks Lowest Recorded Water Use in 32 Years. Retrieved July 28, 2010 from: http://www.ladwpnews.com/go/doc/1475/499743/

Mallach, A. (2009). The case for affordable housing. Planning, 75 (3) : 31-36

Milne, G.and Boardman, B. (2000). Making cold homes warmer: the effect of energy efficiency improvements in low-income homes. Energy Policy, (28):411-424

Mono Lake Committee. (2010). Water conservation: why conserve? Retrieved August 5 , 2010 from: http://www.monolake.org/about/waterconservation\#whyconserve

Moyle, P.B., Israel, J.A. and Purdy, S.E. (2008).Salmon, Steelhead, and Trout in California: Status of an emblematic fauna. Retrieved August 21, 2010 from: http://www.caltrout.org/SOS-Californias-Native-Fish-Crisis-Final-Report.pdf

National Oceanic and Atmospheric Administration (NOAA). (2004). Climatography of the United States, Station: Richmond, CA, $1971-2000$ (No. 20). Retrieved April 29, 2010 from: http://cdo.ncdc.noaa.gov/climatenormals/clim20/ca/047414.pdf

Partnerships for Home Energy Efficiency (2007). An overview. Retrieved July 21, 2010 from:_http://www.energystar.gov/ia/home_improvement/PHEE_Overview_final.pdf 
Reamy, G. and Gates, C. (2009, June). What is weatherization? Presentation at the 2009 National Weatherization Training Conference of the US Department of Energy, Indianapolis, Indiana.

Retzlaff, R. C. (2009). The use of LEED in Planning and Development Regulation: An exploratory analysis. Journal of Planning Education and Research, 29:67-77

Rheem Manufacturing Company (2006). Use and care manual with instructions for the installer (Document no. AP 13787). Retrieved June 14, 2010 from:

http://products.geappliances.com/MarketingObjectRetrieval/Dispatcher?RequestTyp e=PDF\&Name=AP13787\%20GE\%20US\%20Power\%20Vent.pdf

Schweitzer, M. and Tonn, B. (2003). Non-energy Benefits of the US Weatherization Assistance Program: A summary of their scope and magnitude. Applied Energy, 76:321-335.

Sparks, C.W. (2007). Greening Affordable Housing: An Assessment of Housing under the Community Development Block Grant and HOME Investment Partnership Programs. Master's thesis. Texas State University- San Marcos. Retrieved December 29, 2009 from: http://ecommons.txstate.edu/arp/251

Stawitz, C., McGehee, H., Devlin, C.M., Tan, F., and Wong, S. (2008). Increasing awareness of residential energy consumption: data analysis and presentation for EcoMod, a sustainable housing initiative. Proceedings of the 2008 Systems and Information Engineering Design Symposium. Charlottesville: University of Virginia.

Sunikka, M. (2006). Energy efficiency and low-carbon technologies in urban renewal. Building Research \& Information. 34(6): 521-533

The Nature Conservancy (TNC) (2010). Cosumnes River. Retrieved July 18, 2010 from: http://www.nature.org/wherewework/northamerica/states/california/preserves/art6318 .html

The Trailmaster, Inc. (2007). Mono Lake Tufa State Reserve: South Tufa Trail. Sacramento: California Department of Parks and Recreation Retrieved July 22, 2010 from:_http://www.parks.ca.gov/default.asp?page_id=25164

Tonn, B., Schmoyer, R., and Wagner, S. (2003). Weatherizing the homes of low-income energy assistance program clients: a programmatic assessment. Energy Policy, 31: 735-744

US Census Bureau, (n.d.) 2000 Census Summary File 3, Matrices H7, H74, H76, H80, and HCT28 for Census Tract 3604.01; Retrieved March 25, 2010 from: http://factfinder.census.gov/home/saff/main.html?_lang=en

US Census Bureau. (2008). American Housing Survey for the United States: 2007. Retrieved May 12, 2009 from: http://www.census.gov/prod/2008pubs/h150-07.pdf

US Census Bureau. (2010). 2009 American Housing Survey National detailed tables introductory characteristics- Table 1-1 [Spreadsheet]. Retrieved May 12, 2009 from: http://www.census.gov/hhes/www/housing/ahs/ahs09/ahs09.html 
US Department of Energy (DoE) (2001). Weatherize your home-caulk and weather strip. Retrieved March 22, 2010 from: http://www1.eere.energy.gov/library/pdfs/28039.pdf

US Department of Energy (DoE) (2009a).Energy savers: weatherstripping. Retrieved March 24, 2010 from:

http://www.energysavers.gov/your_home/insulation_airsealing/index.cfm/mytopic=11 280

US Department of Energy (DoE) (2009b). Energy savers: air conditioning. Retrieved July 11, 2010 from:

http://www.energysavers.gov/your_home/space_heating_cooling/index.cfm/mytopic= 12370

US Department of Energy (DoE) (2009c). Energy savers: sizing storage and heat pump (with tank) water heaters . Retrieved August 9, 2010 from:

http://www.energysavers.gov/your_home/water_heating/index.cfm/mytopic=12990

US Department of Energy (DoE) (2010a). Energy savers: ceiling fans and other circulating fans. Retrieved July 9, 2010 from:

http://www.energysavers.gov/your_home/space_heating_cooling/index.cfm/mytopic= 12355

US Department of Energy (DoE) (2010b). Energy savers: thermostats and control systems. Retrieved July 10, 2010 from:

http://www.energysavers.gov/your_home/space_heating_cooling/index.cfm/mytopic= 12720

US Environmental Protection Agency (EPA) (2008a). National efficiency standards and specifications for residential and commercial water-using fixtures and appliances. Retrieved June 22, 2010 from: http://www.epa.gov/WaterSense/docs/matrix508.pdf

US Environmental Protection Agency (EPA) (2008b). Acid rain. Retrieved August 10, 2010 from: http://www.epa.gov/acidrain/

US Environmental Protection Agency (EPA) (2010a). Green building: frequent questions. What is green building? Retrieved August 8, 2010 from:_http://www.epa.gov/greenbuilding/pubs/faqs.htm\#1

US Environmental Protection Agency (EPA) (2010b). An introduction to indoor air quality: volatile organic compounds (VOCs). Retrieved August 2, 2010 from:

http://www.epa.gov/iaq/voc.html\#Health Effects

US Environmental Protection Agency (EPA) (2010c). Watersense. Indoor water use in the United States. Retrieved July 22, 2010 from:_http://www.epa.gov/WaterSense/pubs/indoor.html 
US Environmental Protection Agency (EPA) (2010d). Lead in paint, dust, and soil. Renovation, Repair and Painting (RRP). Retrieved August 15, 2010 from: http://www.epa.gov/lead/pubs/renovation.htm

US Environmental Protection Agency (EPA) (2010e). Human-related sources and sinks of carbon dioxide. Retrieved August 11, 2010 from: http://www.epa.gov/climatechange/emissions/co2_human.html

US Environmental Protection Agency (EPA) (2010f). Mid-Atlantic Mountaintop Mining. Retrieved August 8, 2010 from: http://www.epa.gov/region3/mtntop/

US Environmental Protection Agency (EPA) (2010g). EPA greening glossary. http://www.epa.gov/oaintrnt/glossary.htm

US Environmental Protection Agency (EPA) (2010h). Effects of climate change and greenhouse gas mitigation strategies on air quality. Retrieved August 11, 2010 from:_http://cfpub.epa.gov/ncer_abstracts/index.cfm/fuseaction/display.abstractDetail /abstract/9066/report/0

US Environmental Protection Agency (EPA) (2010i). Watersense: what are the environmental benefits of water efficiency? Retrieved August 9, 2010 from: http://www.epa.gov/WaterSense/water_efficiency/environmental_benefits.html

US Department of Housing and Urban Development (HUD) (2005). ECM : Domestic waterheating systems. Retrieved July 1, 2010 from :

http://www.hud.gov/offices/pih/programs/ph/phecc/strat_w1.cfm

US Department of Housing and Urban Development (HUD) (2008). Building Energy Star qualified homes and incorporating energy efficiency and green building into HOMEfunded affordable homes.

US Department Of Housing And Urban Development (HUD). (2009a). Notice of fund availability (nofa) for the Neighborhood Stabilization Program 2 under the American Recovery and Reinvestment Act, 2009 (Docket No. FR-5321-N-01). Washington, D.C.:Author. Retrieved June 12, 2009 from: http://www.hud.gov/offices/cpd/communitydevelopment/programs/neighborhoodspg/ pdf/nsp2_nofa.pdf

US Department of Housing and Urban Development (HUD) (2009b). CPD implementation guidance for the buy American requirement of the American Recovery and Reinvestment Act of 2009 including the exception process (Notice no. CPD-09-05). Retrieved March 27, 2010 from: www.hud.gov/offices/adm/hudclips/notices/cpd/files/09-05cpdn.doc

Utah Divison of Water Resources (n.d.) Water education: municipal drinking water. Retrieved August 9, 2010 from:

http://www.watereducation.utah.gov/WaterInUtah/Municipal/default.asp

West Virginia Conservation Agency (WVCA) (2003). Interaction of competing uses of water. Retrieved August 8, 2010 from: http://www.wvca.us/envirothon/a8.html 
APPENDIX A1 : List of Material and Labor Costs for Green Upgrades and Conventional Equivalents

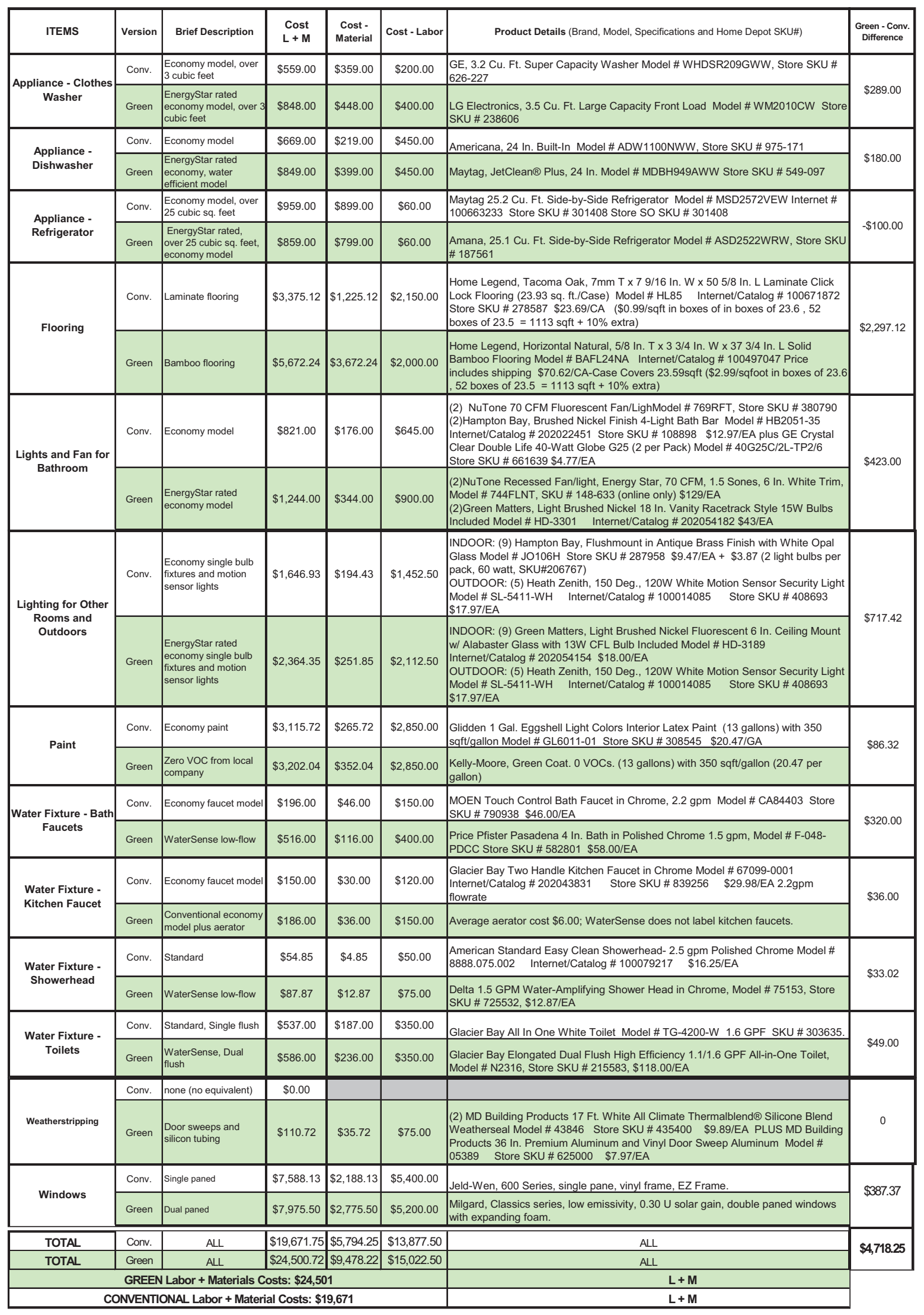


APPENDIX A2 - Labor and material costs for alternative upgrades cost, with product details.

\begin{tabular}{|c|c|c|c|c|}
\hline ITEM & Cost $L+M$ & $\begin{array}{c}\text { Cost - } \\
\text { Material }\end{array}$ & $\begin{array}{l}\text { Cost - } \\
\text { Labor }\end{array}$ & Product Details (Brand, Model, Specifications and Home Depot SKU\#) \\
\hline \begin{tabular}{c|} 
Appliance - \\
Clothes Washer
\end{tabular} & $\$ 848.00$ & $\$ 448.00$ & $\$ 400.00$ & $\begin{array}{l}\text { LG Electronics, } 3.5 \text { Cu. Ft. Large Capacity Front Load Model \# WM2010CW Store } \\
\text { SKU \# } 238606\end{array}$ \\
\hline $\begin{array}{l}\text { Appliance - } \\
\text { Dishwasher }\end{array}$ & $\$ 849.00$ & $\$ 399.00$ & $\$ 450.00$ & Maytag, JetClean® Plus, 24 In. Model \# MDBH949AWW Store SKU \# 549-097 \\
\hline $\begin{array}{l}\text { Appliance - } \\
\text { Refrigerator }\end{array}$ & $\$ 758.00$ & $\$ 698.00$ & $\$ 60.00$ & $\begin{array}{l}\text { Amana, } 25.1 \text { Cu. Ft. Side-by-Side Refrigerator Model \# ASD2522WRW, Store SKU } \\
\text { \# } 187561\end{array}$ \\
\hline $\begin{array}{l}\text { Ceiling Fans } \\
\text { (with lights) }\end{array}$ & $\$ 1,222.85$ & $\$ 247.85$ & $\$ 975.00$ & $\begin{array}{l}\text { (4) \#1: Hampton Bay 36" Minuet III Fan Model AG806C-WH Store SKU \# } 164352 \\
\text { (\$47.97) } \\
\text { (1) \#2: Hampton Bay 44" Hawkins Fan Model YG204-WH. Store SKU \# } 117391 \\
\text { (\$49.97) }\end{array}$ \\
\hline $\begin{array}{l}\text { Ceiling } \\
\text { Insulation }\end{array}$ & $\$ 2,782.50$ & $\$ 2,782.50$ & $\$ 0.00$ & $\begin{array}{l}\text { Flat roof insulation at } 2.50 \text { per square foot, for } 1,113 \text { square feet. (Per contractor } \\
\text { Bay Valley Inc.) }\end{array}$ \\
\hline Clothesline & $\$ 143.88$ & $\$ 53.88$ & $\$ 90.00$ & $\begin{array}{l}\text { (3) Lehigh } 40 \text { Ft. Retractable Clothesline Model \# RC40 Store SKU \# } 386259 \\
\text { \$17.96/EA }\end{array}$ \\
\hline $\begin{array}{l}\text { Digital } \\
\text { Thermostat }\end{array}$ & $\$ 109.00$ & $\$ 39.00$ & $\$ 70.00$ & $\begin{array}{l}\text { RiteTemp Flush Mount } 7 \text { Day Programmable Back Lit Touch Screen Thermostat for } \\
1 \text { Or } 2 \text { Stage Systems Model \# } 6036 \text { Store SKU \# } 474235 \$ 39.00 / E A\end{array}$ \\
\hline Flooring & $\$ 5,672.24$ & $\$ 3,672.24$ & $\$ 2,000.00$ & $\begin{array}{l}\text { Home Legend, Horizontal Natural, } 5 / 8 \mathrm{In} . \mathrm{T} \times 33 / 4 \mathrm{In} . \mathrm{W} \times 373 / 4 \mathrm{In} \text {. L Solid } \\
\text { Bamboo Flooring Model \# BAFL24NA Internet/Catalog \# } 100497047 \text { Price includes } \\
\text { shipping } \$ 70.62 / \text { CA-Case Covers } 23.59 \text { sqft }(\$ 2.99 / \text { sqfoot in boxes of } 23.6,52 \\
\text { boxes of } 23.5=1113 \text { sqft }+10 \% \text { extra) }\end{array}$ \\
\hline $\begin{array}{l}\text { Lights \& Fans } \\
\text { with Lights for } \\
\text { Bathrooms }\end{array}$ & $\$ 1,244.00$ & $\$ 344.00$ & $\$ 900.00$ & $\begin{array}{l}\text { (2)NuTone Recessed Fan/light, Energy Star, } 70 \text { CFM, } 1.5 \text { Sones, } 6 \text { In. White Trim, } \\
\text { Model \# 744FLNT, SKU \# 148-633 (online only) \$129/EA } \\
\text { (2)Green Matters, Light Brushed Nickel } 18 \text { In. Vanity Racetrack Style 15W Bulbs } \\
\text { Included Model \# HD-3301 Internet/Catalog \# 202054182 \$43/EA }\end{array}$ \\
\hline $\begin{array}{l}\text { Lighting - Indoor } \\
\text { \& Outdoor } \\
\text { (excludes } \\
\text { bathrooms) }\end{array}$ & $\$ 1,314.35$ & $\$ 161.85$ & $\$ 1,152.50$ & 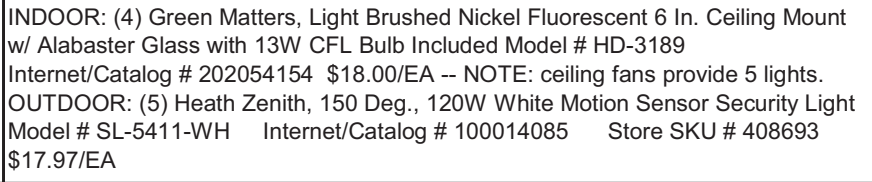 \\
\hline Paint & $\$ 3,202.04$ & $\$ 352.04$ & $\$ 2,850.00$ & $\begin{array}{l}\text { Kelly-Moore, Green Coat. 0 VOCs. (13 gallons) with } 350 \text { sqft/gallon (\$20.47 per } \\
\text { gallon) }\end{array}$ \\
\hline $\begin{array}{l}\text { Water Fixture - } \\
\text { Bath Faucets }\end{array}$ & $\$ 516.00$ & $\$ 116.00$ & $\$ 400.00$ & $\begin{array}{l}\text { Price Pfister Pasadena } 4 \text { In. Bath in Polished Chrome } 1.5 \text { gpm, Model \# F-048- } \\
\text { PDCC Store SKU \# } 582801 \text { \$58.00/EA }\end{array}$ \\
\hline $\begin{array}{l}\text { Water Fixture - } \\
\text { Kitchen Faucet } \\
\text { Aerator }\end{array}$ & $\$ 36.00$ & $\$ 6.00$ & $\$ 30.00$ & Average aerator cost $\$ 6.00$. (WaterSense does not label kitchen faucets.) \\
\hline $\begin{array}{l}\text { Water Fixture - } \\
\text { Showerhead }\end{array}$ & $\$ 87.87$ & $\$ 12.87$ & $\$ 75.00$ & $\begin{array}{l}\text { Delta 1.5 GPM Water-Amplifying Shower Head in Chrome, Model \# 75153, Store } \\
\text { SKU \# 725532, \$12.87/EA }\end{array}$ \\
\hline $\begin{array}{l}\text { Water Fixture - } \\
\text { Toilets Tank Bag }\end{array}$ & $\$ 67.98$ & $\$ 7.98$ & $\$ 60.00$ & $\begin{array}{l}\text { New Resources Group Toilet FlushLess water displacement blatter bag. } 2.5 \text { quarts } \\
\text { displaced per bag. Amazon.com Item \#: B002ED3J4K \$3.99/EA }\end{array}$ \\
\hline Waterheater & $\$ 1,403.04$ & $\$ 603.04$ & $\$ 800.00$ & $\begin{array}{l}\text { GE Energy Star } 50 \text { Gallon Natural Gas Storage Water Heater, } 36 \mathrm{~K} \text { BTU, Ultra Low } \\
\text { Nox, E =0.62 Model \# SG50T12TXK00, Store SKU \# 170910, } \$ 568.00 / E A \text {, } \\
\text { SEISMIC STRAP Spacemaker Water Heater Earthquake Restraining Straps Model } \\
\# \text { E E-75 Internet/Catalog \# } 100067210 \quad \text { Store SKU \# } 495011 \quad \$ 13.47 / \text { EA }\end{array}$ \\
\hline $\begin{array}{l}\text { Weather- } \\
\text { stripping }\end{array}$ & $\$ 110.72$ & $\$ 35.72$ & $\$ 75.00$ & $\begin{array}{l}\text { (2) MD Building Products } 17 \text { Ft. White All Climate Thermalblend® Silicone Blend } \\
\text { Weatherseal Model \# } 43846 \text { Store SKU \# 435400 \$9.89/EA PLUS MD Building } \\
\text { Products } 36 \text { In. Premium Aluminum and Vinyl Door Sweep Aluminum Model \# } \\
05389 \quad \text { Store SKU \# } 625000 \quad \$ 7.97 / \text { EA }\end{array}$ \\
\hline TOTAL & $\$ 20,367$ & $\$ 9,980$ & $\$ 10,388$ & Alternative Upgrades Total Costs $=\$ 20,367$ \\
\hline
\end{tabular}

Note: Original Upgrades included windows, Alternative Upgrades drops window upgrades, and instead improves ceiling insulation. Using laminate flooring instead of bamboo brings to total cost to $\$ 18,740$ while still improving indoor air quality. 


\section{Appendix B: Calculations \& Industry Recommendations for Materials Sizing}

\section{Ceiling Fan Sizing :}

Energy Star (n.d.) Ceiling fan basics. Retrieved July 14, 2010 from:

http://www.energystar.gov/index.cfm?c=ceiling_fans.pr_ceiling_fans_basics

\begin{tabular}{|c|c|c|c|}
\hline living room & & small bedrc & om \\
\hline 12.2 & 22.4 & 11.5 & 8.10 \\
\hline 146 & 268 & 137 & 106 \\
\hline & 39128 & & 14522 \\
\hline & 271.7222222 & & 100.8472222 \\
\hline $78 \%$ & 211.9433333 & $78 \%$ & 78.66083333 \\
\hline & neter & & 36" diameter \\
\hline kitchen & & & \\
\hline 9.3 & 20.8 & master bed & room \\
\hline 111 & 248 & 15.11 & $\overline{13.8}$ \\
\hline & 27528 & 191 & 164 \\
\hline & 191.1666667 & & 31324 \\
\hline $78 \%$ & 149.11 & & 217.5277778 \\
\hline & neter & $78 \%$ & 169.6716667 \\
\hline & & & 44" diameter \\
\hline converted b & & & \\
\hline 10.2 & 20.8 & & \\
\hline 122 & 248 & & \\
\hline & 30256 & & \\
\hline & 210.1111111 & & \\
\hline $78 \%$ & 163.8866667 & & \\
\hline (will also r & $\begin{array}{l}\text { meter } \\
\text { ing to install) }\end{array}$ & & \\
\hline
\end{tabular}

\section{Flooring sizing:}

$1427 * 78 \%=1,113 \mathrm{sq} \mathrm{ft}$

(The Karen Rd home floor plans were scaled down to 1,113 sq. ft. to represent the typical home per the research. See Chapter 3.) 


\section{Lighting}

NOTE: 10 fixtures, 1 of which is the laundry room. This bulb remains in baseline configuration. Thus, effectively, there are only 9 places lights (or fans) are installed. Of the 9 fixtures that are modified (in conventional configuration, original \& alternative upgrades), one need wiring (garage bedroom). In all instances, 8 are regular installs, and 1 is a newly wired.

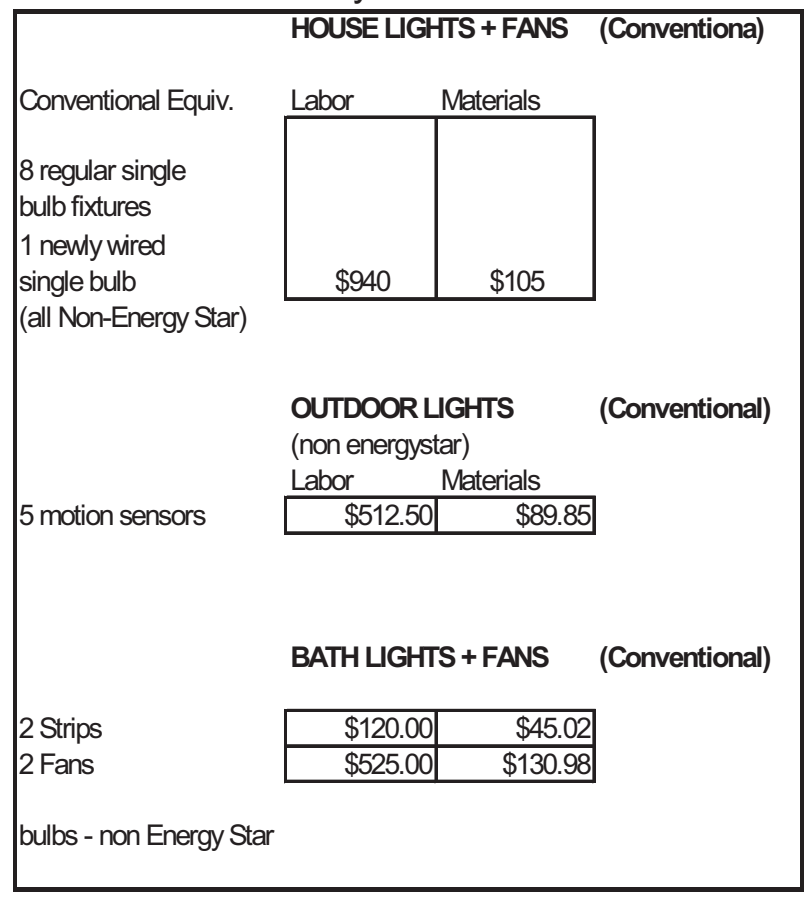

\begin{tabular}{|c|c|c|c|}
\hline & HOUSE LI & GHTS (Origi & nal) \\
\hline Original & Labor & Materials & \\
\hline $\begin{array}{l}8 \text { regular single bulb } \\
\text { Energy Star fixtures }\end{array}$ & $\$ 1,280.00$ & & \\
\hline $\begin{array}{l}1 \text { newly wired single } \\
\text { bulb* }\end{array}$ & $\$ 320.00$ & $\$ 162.00$ & \\
\hline & $\begin{array}{l}\text { OUTDOOF } \\
\text { (non energ }\end{array}$ & $\begin{array}{l}\text { P LIGHTS } \\
\text { ystar) }\end{array}$ & (Original) \\
\hline 5 motion sensors & $\begin{array}{l}\text { Labor } \\
\$ 512.50 \\
\end{array}$ & $\begin{array}{l}\text { Materials } \\
\$ 89.85 \\
\end{array}$ & \\
\hline & BATH I & LIGHTS + FA & NS (Original) \\
\hline 2 Strips - ES & $\$ 375.00$ & $\$ 86.00$ & \\
\hline $\begin{array}{l}2 \text { Fans - ES. } \\
\text { (come with ES } \\
\text { bulbs) }\end{array}$ & $\$ 525.00$ & $\$ 258.00$ & \\
\hline
\end{tabular}

\begin{tabular}{|c|c|c|c|}
\hline & \multicolumn{3}{|c|}{ HOUSE LIGHTS + FANS (Alternative) } \\
\hline \multirow{3}{*}{$\begin{array}{l}\text { Alternative } \\
4 \text { regular single } \\
\text { bulb, Energy } \\
\text { Star fixtures } \\
5 \text { ceiling fans; } 1 \\
\text { newly wired }\end{array}$} & Labor & \multicolumn{2}{|l|}{ Materials } \\
\hline & $\$ 640.00$ & $\$ 72.00$ & \\
\hline & $\$ 975.00$ & $\$ 247.85$ & $\begin{array}{c}<<\text { ceiling fans are NOT included } \\
\text { in the LIGHTING costing portion } \\
\quad ; \text { seperately accounted. }\end{array}$ \\
\hline \multirow{4}{*}{5 motion sensors } & \multicolumn{3}{|c|}{$\begin{array}{l}\text { OUTDOOR LIGHTS (Alternative) } \\
\text { (non energystar) }\end{array}$} \\
\hline & Labor & Materials & \\
\hline & $\$ 512.50$ & $\$ 89.85$ & \\
\hline & \multicolumn{3}{|c|}{ BATH LIGHTS + FANS (Alternative) } \\
\hline $\begin{array}{l}2 \text { Strips - ES } \\
2 \text { Fans - ES. } \\
\text { (come with ES } \\
\text { bulbs) }\end{array}$ & $\begin{array}{l}\$ 375.00 \\
\$ 525.00\end{array}$ & $\begin{array}{r}\$ 86.00 \\
\$ 258.00\end{array}$ & \\
\hline
\end{tabular}




\section{Paint Volume Calculation}

Rob Kimball at Kelly-Moore, San Luis Obispo, CA. (805)541-5116. March 22, 2010. Personal communication..

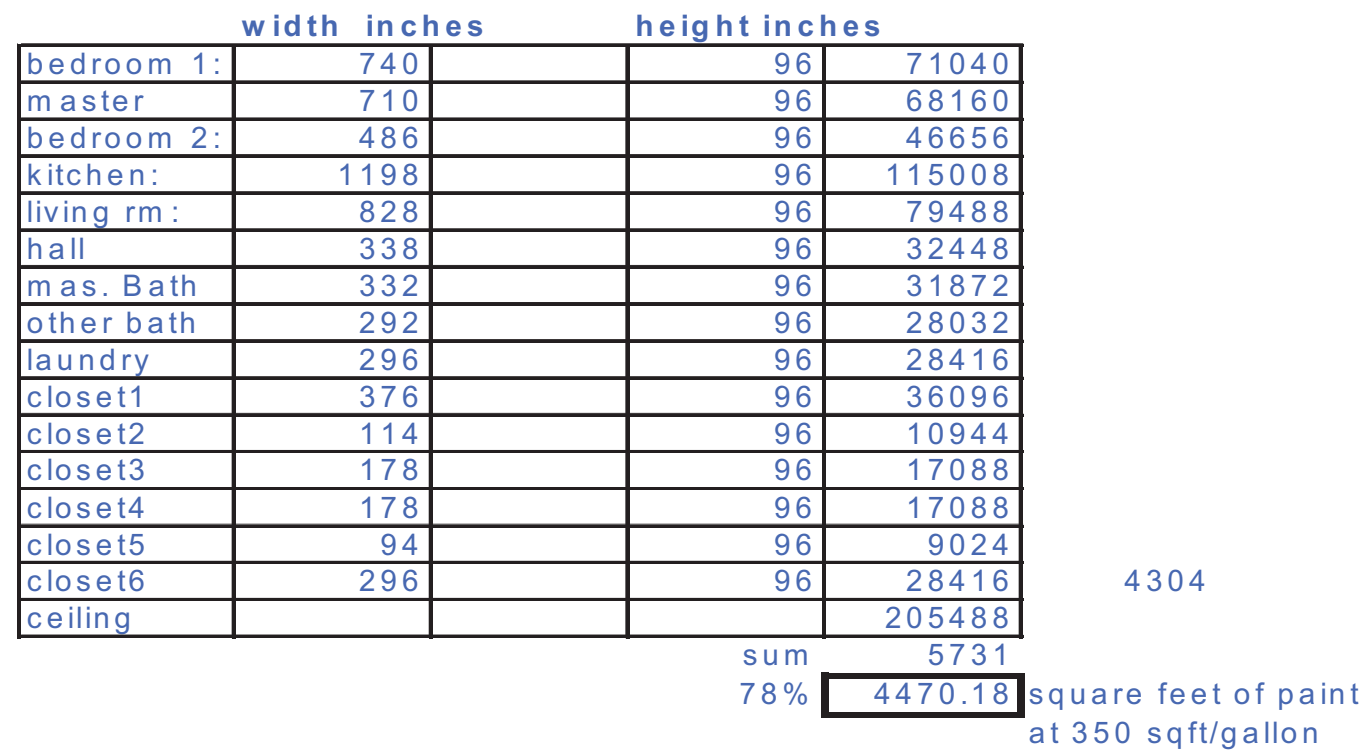

12.77194 Gallons of Paint

$13 \mathrm{gallons}$ of $\mathrm{Paint}$

\section{Perimeter of Walls (for insulation)}

Rates Guy Roth of Bay Valley, Inc. personal communication.

Bay Valley Insulation, Fremont, CA. (510) 791-5535. May 5, 2010.

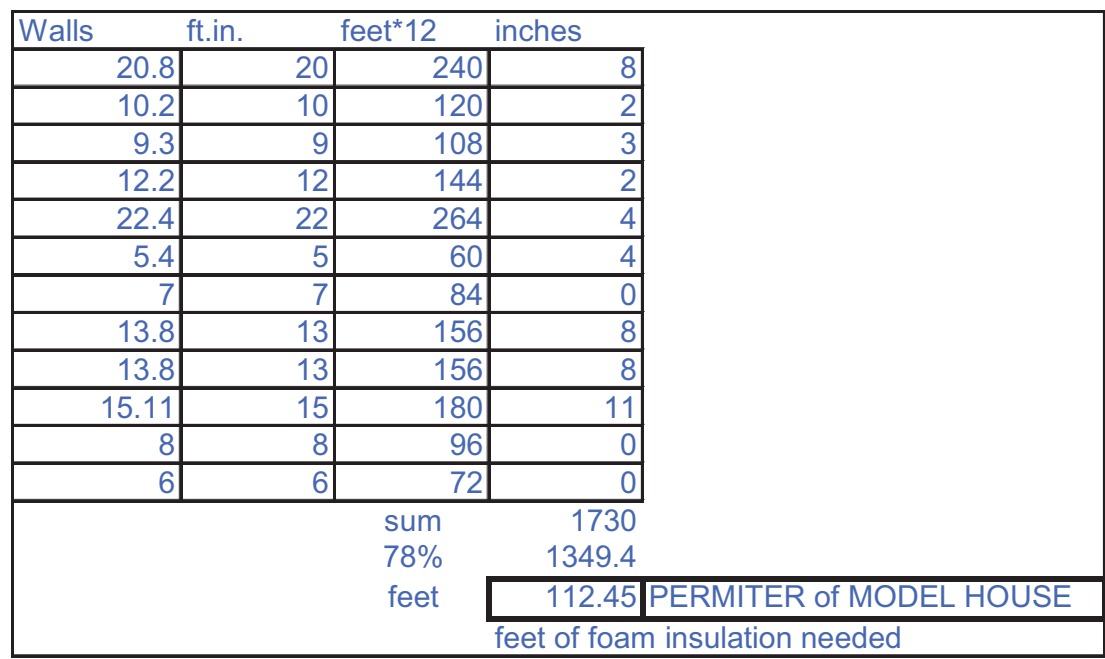




\section{Water Heater Sizing}

US Department of Energy (2009). Sizing storage and heat pump (with tank) water heaters.

Accessed June 17, 2010 from:

http://www.energysavers.gov/your_home/water_heating/index.cfm/mytopic=12990

\begin{tabular}{|c|c|r|r|}
\hline $\begin{array}{c}\text { Hot water } \\
\text { needed }\end{array}$ & Water Usage & $\begin{array}{c}\text { Times per } \\
\text { one hour }\end{array}$ & $\begin{array}{c}\text { Hot H20 (in } \\
\text { gallons) }\end{array}$ \\
\hline 12 & Shower & 1 & 12 \\
\hline 9 & Bath & 0 & 0 \\
\hline 2 & Shaving & 0 & 0 \\
\hline 4 & Hands \& face washing & 5 & 20 \\
\hline 4 & Hair shampoo & 0 & 4 \\
\hline 4 & Hand dishwashing & 0 & 0 \\
\hline 14 & Automatic dishwasher & 0 & 0 \\
\hline 5 & Food preparation & 0 & 0 \\
\hline 26 & Wringer clothes washer & & 16 \\
\hline 32 & Automatic clothes washer & 0.5 & 52 \\
\hline & & SUM & \\
\hline
\end{tabular}

\section{Window Size Calculation}

Home Depot Store \#1052, San Luis Obispo, CA (805) 596-0857. March 24, 2010.

\begin{tabular}{|c|r|r|l|l|l|}
\hline \multirow{2}{*}{$\begin{array}{c}\text { Scaled } \\
\text { Windows }\end{array}$} & \multicolumn{2}{|c|}{ Milgard Windows - Tuscany Model } & WIDTH & HEIGHT & TYPE \\
\cline { 2 - 6 } & Width (in) & Height (in) & feet/inch & feet/inch & \\
\hline $3^{*}$ & 19 & 19 & $1^{\prime} 7^{\prime \prime}$ & $1^{\prime} 7^{\prime \prime}$ & Crank (or Fixed) \\
\hline 1 & 36 & 28 & $3^{\prime}$ & $2^{\prime} 4^{\prime \prime}$ & SingleHung \\
\hline 1 & 28 & 37 & $2^{\prime} 4^{\prime \prime}$ & $3^{\prime}$ & SingleHung \\
\hline 1 & 37 & $41.5^{\prime \prime}$ & $3^{\prime} 1^{\prime \prime}$ & $3^{\prime} 5.5^{\prime \prime}$ & SingleHung \\
\hline 1 & 37 & $49^{\prime \prime}$ & $3^{\prime} 1^{\prime \prime}$ & $4^{\prime} 1^{\prime \prime}$ & SingleHung \\
\hline 1 & 37 & 39 & $3^{\prime} 1^{\prime \prime}$ & $3^{\prime} 3^{\prime \prime}$ & SingleHung \\
\hline 2 & 37.5 & 56 & $4^{\prime} 8^{\prime \prime}$ & $3^{\prime} 1.5^{\prime \prime}$ & Picture \\
\hline 1 & 54.5 & 26.5 & $4^{\prime} 6.5^{\prime \prime}$ & $2^{\prime} 2.5^{\prime \prime}$ & Picture \\
\hline 1 & standard & 83 & standard & $6^{\prime} 11^{\prime \prime}$ & Slider \\
\hline
\end{tabular}

*1:Privacy + Tempered, 2: Privacy, 3: Nothing 


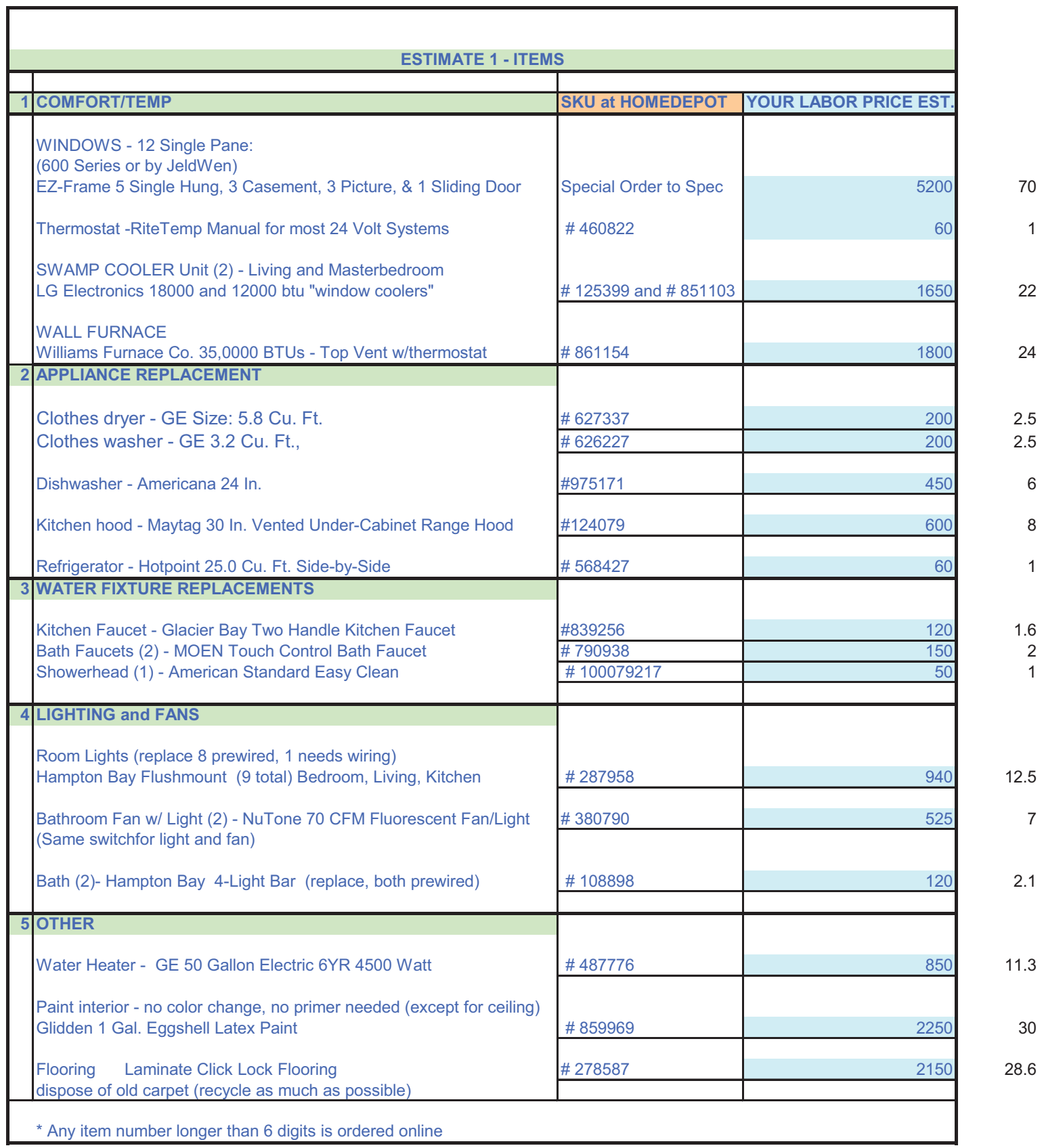




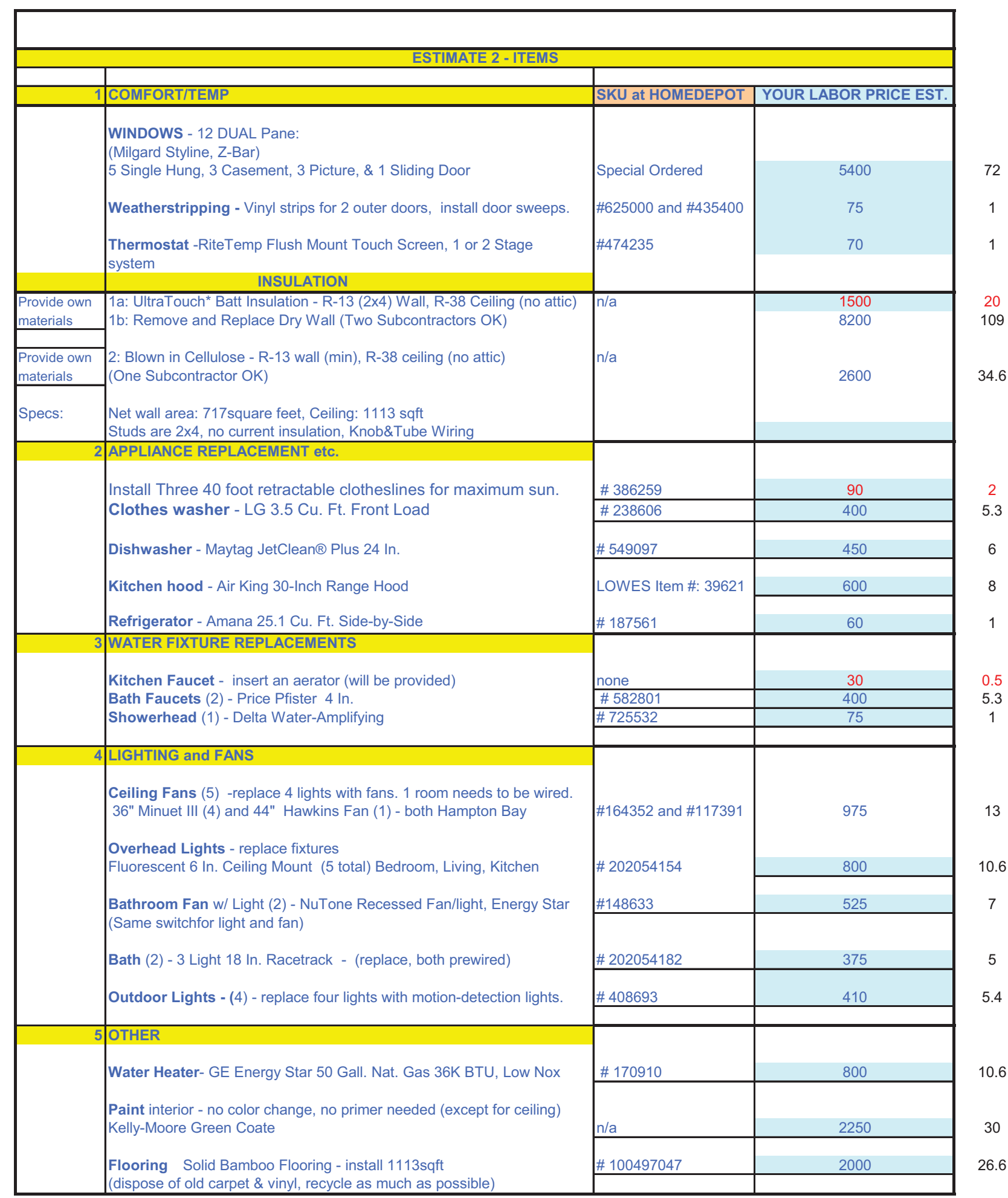

Note: Any item number longer than 6 digits is ordered online

* Ultratouch is recycled blue jeans, formaldehyde free

6 OTHER

ELECTRICAL (Re-wire, Subpanel, Meter) 
Appendix D1 - Home Energy Saver Report - Baseline Configuration

\section{HOME ENERGY SAVER}

REPORT

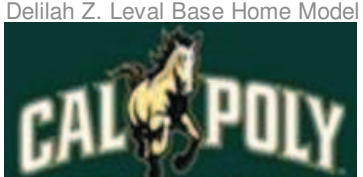

MUSTANGS

This report is generated by the Home Energy Saver

web-based energy audit tool, developed by

the U.S. Department of Energy's

Lawrence Berkeley National Laboratory,

and can be reached at http://hes.Ibl.gov 


\section{HOUSE CONFIGURATION}

\section{General Information}

Name or other identifier this home/session : ; User's email address : delilahzoe@gmail.com; Purpose of this assessment : Hypothetical analysis; Address : 1276 Karen Road; Other text if other is checked : ; City : San Pablo; State : California; City with most similar climate to modeled house : Oakland; Year house was built : 1953; People living in the house, by age - 0 to 5 years : 0 ; People living in the house, by the age - 6-13:1; People living in the house, by the age - 14-64 : 2; People living in the house, by the age - 65 plus : 0; Check for actual electricity prices in your area. : no; Utilities List : ; Select your tariff from the list below. :

\section{Energy Prices}

Energy Prices - Electricity : 0.144; Energy Prices - Piped Natural Gas : 1.270; Energy Prices - Liquid Propane Gas (LPG) : 2.770; Energy Prices - Fuel Oil : 2.940;

\section{Exterior Shading}

Extension of roof eaves or patios - Front : 1.00; Extension of roof eaves or patios - Right : 1.00; Extension of roof eaves or patios - Back : 1.00; Extension of roof eaves or patios - Left : 1.00; Height of large shade trees - Front : 0 ; Height of large shade trees - Right : 0; Height of large shade trees - Back : 0 ; Height of large shade trees - Left : 0; Height of neighboring houses stories - Front : One; Height of neighboring houses stories - Right : One; Height of neighboring houses stories - Back : One; Height of neighboring houses stories - Left : One

\section{Air Tightness}

Does the house have weatherstripping : No; Enter the measured or estimated air leakage rate : 0.00

\section{Foundation Floor}

Foundation type : Slab-on-grade Foundation; Foundation insulation level : None; Insulation level of the floor above the basement or crawlspace : R-0 (no insulation);

\section{Walls}

Darkness of exterior wall surfaces (left wall slider) : 0.70; Do all the walls have similar construction? : Yes; Darkness of exterior wall surfaces (right wall slider) : 0.70; Darkness of exterior wall surfaces (back wall slider) : 0.70; Darkness of exterior wall surfaces (slider) : 0.70; Wood Siding : ; Wood Siding : ; Wood Siding : ; Wood Siding : ; Stucco : ; Wood Siding : ; Stucco : ; Stucco : ; Stucco : ; Vinyl Siding : ; Stucco : ; Vinyl Siding : ; Vinyl Siding : ; Vinyl Siding : ; Aluminum Siding : ; Vinyl Siding : ; Aluminum Siding : ; Aluminum Siding : ; Aluminum Siding : ; Brick Veneer : ; Aluminum Siding : ; Brick Veneer : ; Brick Veneer : ; Brick Veneer : ; Wood Siding : ; Wood Siding : ; Brick Veneer : ; Wood Siding: ; Wood Siding: ; Stucco : ; Stucco : ; Wood Siding : ; Stucco : ; Stucco : ; Vinyl Siding : ; Vinyl Siding: ; Stucco : ; Vinyl Siding : ; Vinyl Siding : ; Aluminum Siding : ; Aluminum Siding :; Vinyl Siding : ; Aluminum Siding : ; Aluminum Siding : ; Brick Veneer : ; Brick Veneer :; Aluminum Siding : ; Brick Veneer : ; Brick Veneer : ; Wood Siding : ; Wood Siding : ; Brick Veneer : ; Wood Siding : ; Wood Siding : ; Stucco : ; Stucco : ; Wood Siding : ; Stucco : ; Stucco : ; Vinyl Siding : ; Vinyl Siding : ; Stucco : ; Vinyl Siding : ; Vinyl Siding : ; Aluminum Siding : ; Aluminum Siding : ; Vinyl Siding : ; Aluminum Siding : ; Aluminum Siding : ; Brick Veneer : ; Brick Veneer : ; Aluminum Siding : ; Brick Veneer :; Brick Veneer : ; Wood Siding : ; Wood Siding :; Brick Veneer : ; Wood Siding : ; Wood Siding :; Stucco : ; Stucco : ; Wood Siding : ; Stucco : ; Stucco : ; Vinyl Siding : ; Vinyl Siding : ; Stucco : ; Vinyl Siding : ; Vinyl Siding : ; Aluminum Siding : ; Aluminum Siding :; Vinyl Siding ; Aluminum Siding : ; Aluminum Siding : ; Brick Veneer : ; Brick Veneer :; Aluminum Siding : ; Brick Veneer : ; Brick Veneer : ; Wood Siding : ; Wood Siding : ; Brick Veneer : ; Wood Siding : ; Wood Siding : ; Stucco : ; Stucco : ; Wood Siding : ; Stucco : ; Stucco : ; Vinyl Siding : ; Vinyl Siding : ; Stucco : ; Vinyl Siding : ; Vinyl Siding : ; Aluminum Siding : ; Aluminum Siding : ; Vinyl Siding : ; Aluminum Siding : ; Aluminum Siding : ; Brick Veneer : ; Brick Veneer : ; Aluminum Siding : ; Brick Veneer : ; Brick Veneer : ; Wood Siding : ; Wood Siding : ; Brick Veneer : ; Wood Siding : ; Wood Siding : ; Stucco : ; Stucco : ; Wood Siding : ; Stucco : ; Stucco : ; Vinyl Siding : ; Vinyl Siding: : Stucco : ; Vinyl Siding : ; Vinyl Siding : ; Aluminum Siding : ; Aluminum Siding : ; Vinyl Siding : ; Aluminum Siding : ; Aluminum Siding : ; Brick Veneer : ; Brick Veneer: ; Aluminum Siding : ; Brick Veneer : ; Brick Veneer : ; Wood Siding : ; Wood Siding : ; Brick Veneer : ; Wood Siding : ; Wood Siding : ; Stucco : ; Stucco : ; Wood Siding : ; Stucco : ; Stucco : ; Vinyl Siding : ; Vinyl Siding :; Stucco : ; Vinyl Siding : ; Vinyl Siding : ; Aluminum Siding : ; Aluminum Siding : ; Vinyl Siding : ; Aluminum Siding: ; Aluminum Siding : ; Brick Veneer : ; Brick Veneer : ; Aluminum Siding : ; Brick Veneer : ; Brick Veneer : ; Wood Siding : ; Wood Siding : ; Brick Veneer : ; Wood Siding : ; Wood Siding : ; Stucco : ; Stucco :; Wood Siding :; Stucco : ; Stucco : ; Vinyl Siding : ; Vinyl Siding :; Stucco : ; Vinyl Siding : ; Vinyl Siding : ; Aluminum Siding : ; Aluminum Siding : ; Vinyl Siding: ; Aluminum Siding :; Aluminum Siding :; Brick Veneer : ; Brick Veneer : ; Aluminum Siding : ; Brick Veneer : ; Brick Veneer :; Wood Siding : ; Wood Siding : ; Brick Veneer : ; Wood Siding : ; Wood Siding : ; Stucco : ; Stucco : ; Wood Siding : ; Stucco : ; Stucco : ; Vinyl Siding : ; Vinyl Siding : ; Stucco : ; Vinyl Siding : ; Vinyl Siding : ; Aluminum Siding :; Aluminum Siding : ; Vinyl Siding : ; Aluminum Siding : ; Aluminum Siding : ; Brick Veneer : ; Brick Veneer : ; Aluminum Siding : ; Brick Veneer : ; Brick Veneer :; Wood Siding : ; Wood Siding :; Brick Veneer :; Wood Siding :; Wood Siding :; Stucco : ; Stucco :; Wood Siding :; Stucco : ; Stucco : ; Vinyl Siding : ; Vinyl Siding : ; Stucco : ; Vinyl Siding : ; Vinyl Siding : ; Aluminum Siding : ; Aluminum Siding : ; Vinyl Siding : ; Aluminum Siding : ; Aluminum Siding : ; Brick Veneer : ; Brick Veneer : ; Aluminum Siding : ; Brick Veneer :; Brick Veneer : ; Wood Siding : ; Wood Siding : ; Brick Veneer : ; Wood Siding : ; Wood Siding : ; Stucco : ; Stucco : ; Wood Siding : ; Stucco : ; Stucco : ; Vinyl Siding : ; Vinyl Siding : ; Stucco : ; Vinyl Siding : ; Vinyl Siding : ; Aluminum Siding : ; Aluminum Siding : ; Vinyl Siding : ; Aluminum Siding : ; Aluminum Siding : ; Brick Veneer : ; Brick Veneer : ; Aluminum Siding : ; Brick Veneer : ; Brick Veneer : ; Wood Siding: ; Wood Siding : ; Brick Veneer : ; Wood Siding : ; Wood Siding : ; Stucco : ; Stucco : ; Wood Siding : ; Stucco : ; Stucco : ; Vinyl Siding : ; Vinyl Siding : ; Stucco : Vinyl Siding : ; Vinyl Siding : ; Aluminum Siding :; Aluminum Siding : ; Vinyl Siding : ; Aluminum Siding :; Aluminum Siding : ; Brick Veneer : ; Brick Veneer : ; Aluminum Siding : ; Brick Veneer : ; Brick Veneer : ; Wood Siding : ; Wood Siding : ; Brick Veneer : ; Wood Siding : ; Wood Siding : ; Stucco : ; Stucco : ; Wood Siding : ; Stucco : Stucco : ; Vinyl Siding : ; Vinyl Siding: ; Stucco : ; Vinyl Siding : ; Vinyl Siding : ; Aluminum Siding : ; Aluminum Siding : ; Vinyl Siding : ; Aluminum Siding : ; Aluminum Siding : ; Brick Veneer : ; Brick Veneer : ; Aluminum Siding : ; Brick Veneer : ; Brick Veneer : ; Wood Siding : ; Wood Siding : ; Brick Veneer : ; Wood Siding : ; Wood Siding : ; Stucco : ; Stucco : ; Wood Siding : ; Stucco : ; Stucco : ; Vinyl Siding : ; Vinyl Siding : ; Stucco : ; Vinyl Siding : ; Vinyl Siding : ; Aluminum Siding : ; Aluminum Siding : ; Vinyl Siding : ; Aluminum Siding: ; Aluminum Siding : ; Brick Veneer : ; Brick Veneer : ; Aluminum Siding : ; Brick Veneer : ; Brick Veneer : ; Wood Siding : ; Wood Siding : ; Brick Veneer : ; Wood Siding : ; Wood Siding : ; Stucco : ; Stucco : ; Wood Siding : ; Stucco : ; Stucco : ; Vinyl Siding : ; Vinyl Siding : ; Stucco : ; Vinyl Siding : ; Vinyl Siding : ; Aluminum Siding: ; Aluminum Siding : ; Vinyl Siding : ; Aluminum Siding : ; Aluminum Siding : ; Brick Veneer : ; Brick Veneer : ; Aluminum Siding ; Brick Veneer : ; Brick Veneer : ; Wood Siding : ; Wood Siding : ; Brick Veneer : ; Wood Siding : ; Wood Siding : ; Stucco : ; Stucco : ; Wood Siding : ; Stucco : ; Stucco ; Vinyl Siding : ; Vinyl Siding : ; Stucco : ; Vinyl Siding : ; Vinyl Siding : ; Aluminum Siding : ; Aluminum Siding : ; Vinyl Siding : ; Aluminum Siding : ; Aluminum Siding : ; Brick Veneer : ; Brick Veneer : ; Aluminum Siding : ; Brick Veneer : ; Brick Veneer : ; Wood Siding : ; Wood Siding : ; Brick Veneer : ; Wood Siding : ; Wood Siding : ; Stucco : ; Stucco : ; Wood Siding : ; Stucco : ; Stucco : ; Vinyl Siding : ; Vinyl Siding : ; Vinyl Siding : ; Stucco : ; Vinyl Siding : ; Aluminum Siding : ; Aluminum Siding : ; Aluminum Siding : ; Vinyl Siding:; Aluminum Siding: ; Brick Veneer : ; Brick Veneer : ; Brick Veneer :; Aluminum Siding : ; Brick Veneer : ; Wood Siding: ; Wood Siding ; Wood Siding : ; Brick Veneer : ; Wood Siding : ; Stucco : ; Stucco : ; Stucco : ; Wood Siding : ; Stucco : ; Vinyl Siding : ; Vinyl Siding : ; Vinyl Siding : ; Stucco : ; Vinyl Siding : ; Aluminum Siding: ; Aluminum Siding : ; Aluminum Siding : ; Vinyl Siding : ; Aluminum Siding : ; Brick Veneer :; Brick Veneer : ; Brick Veneer : ; Aluminum Siding : ; Brick Veneer : ; Wood Siding : ; Wood Siding : ; Wood Siding : ; Brick Veneer : ; Wood Siding : ; Stucco : ; Stucco : ; Stucco : ; Wood Siding : ; Stucco : ; Vinyl Siding : ; Vinyl Siding : ; Vinyl Siding : ; Stucco : ; Vinyl Siding : ; Aluminum Siding : ; Aluminum Siding : ; Aluminum Siding : ; Vinyl Siding : ; Aluminum Siding : ; Brick Veneer : ; Brick Veneer : ; Brick Veneer : ; Aluminum Siding : ; Brick Veneer : ; Wood Siding : ; Wood Siding : ; Wood Siding : ; Brick Veneer : ; Wood Siding : ; Stucco : ; Stucco : ; Stucco : ; Wood Siding : ; Stucco : ; Vinyl Siding : ; Vinyl Siding : ; Vinyl Siding :; Stucco : ; Vinyl Siding : ; Aluminum Siding : ; Aluminum Siding : ; Aluminum Siding : ; Vinyl Siding : ; Aluminum Siding : ; Brick Veneer : ; Brick Veneer : ; Brick Veneer : ; Aluminum Siding : ; Brick Veneer : ; Wood Siding : ; Wood Siding : ; Wood Siding : ; Brick Veneer : ; Wood Siding : ; Stucco : ; Stucco : ; Stucco : ; Wood Si 96 : ; Stucco : ; Vinyl Siding : ; Vinyl Siding : ; Vinyl Siding : ; Stucco : ; Vinyl Siding : ; Aluminum Siding : ; Aluminum Siding : ; Aluminum Siding : ; Vinyl Siding : ; Aluminum Siding : ; Brick Veneer : ; Brick Veneer : ; Brick Veneer : ; Aluminum Siding : ; Brick 
Veneer : ; Wood Siding : ; Wood Siding : ; Wood Siding : ; Brick Veneer : ; Wood Siding : ; Stucco : ; Stucco:

Siding : ; Vinyl Siding : ; Stucco : ; Vinyl Siding : ; Aluminum Siding : ; Aluminum Siding : ; Aluminum Siding :; Vinyl Siding :;Alum : Brick Veneer: ; Wood Siding : ; Stucco : ; Stucco : ; Stucco : ; Wood Siding : ; Stucco : ; Vinyl Siding : ; Vinyl Siding : ; Vinyl Siding : ; Stucco : ; Vinyl Siding : ; Aluminum Siding : ; Aluminum Siding : ; Aluminum Siding : ; Vinyl Siding : ; Aluminum Siding : ; Brick Veneer : ; Brick Veneer : ; Brick Veneer : ; Aluminum Siding : ; Brick Veneer : ; Wood Siding : ; Wood Siding : ; Wood Siding :; Brick Veneer : ; Wood Siding : ; Stucco : ; Stucco : ; Stucco : ; Wood Siding : ; Stucco : ; Vinyl Siding : ; Vinyl Siding : ; Vinyl Siding : ; Stucco : ; Vinyl Siding : ; Aluminum Siding :; Aluminum Siding : ; Aluminum Siding : ; Vinyl Siding : ; Aluminum Siding : ; Brick Veneer : ; Brick Veneer: ; Brick Veneer : ; Aluminum Siding:; Brick Veneer : ; Wood Siding : ; Wood Siding : ; Wood Siding : ; Brick Veneer : ; Wood Siding : ; Stucco : ; Stucco :; Stucco : ; Wood Siding : ; Stucco : ; Vinyl Siding : ; Vinyl Siding : ; Vinyl Siding : ; Stucco : ; Vinyl Siding : ; Aluminum Siding : ; Aluminum Siding : ; Aluminum Siding :; Vinyl Siding : ; Aluminum Siding : ; Brick Veneer : ; Brick Veneer : ; Brick Veneer : ; Aluminum Siding : ; Brick Veneer : ; Wood Siding : ; Wood Siding : ; Wood Siding : ; Brick Veneer:; Wood Siding : ; Stucco : ; Stucco : ; Stucco : ; Wood Siding : ; Stucco : ; Vinyl Siding : ; Vinyl Siding : ; Vinyl Siding : ; Stucco : ; Vinyl Siding :; Aluminum Siding : ; Aluminum Siding : ; Aluminum Siding : ; Vinyl Siding : ; Aluminum Siding : ; Brick Veneer : ; Brick Veneer : ; Brick Veneer : ; Aluminum Siding : ; Brick Veneer:; Wood Siding:; Wood Siding : ; Wood Siding :; Brick Veneer : ; Wood Siding : ; Stucco : ; Stucco : ; Stucco : ; Wood Siding : ; Stucco : ; Vinyl Siding : ; Vinyl Siding : ; Vinyl Siding : ; Stucco : ; Vinyl Siding : ; Aluminum Siding :; Aluminum Siding :; Aluminum Siding : ; Vinyl Siding :; Aluminum Siding : ; Brick Veneer : ; Brick Veneer : ; Brick Veneer : ; Aluminum Siding : ; Brick Veneer : ; Wood Siding : ; Wood Siding : ; Wood Siding : ; Brick Veneer : ; Wood Siding : ; Stucco : ; Stucco : ; Stucco : ; Wood Siding : ; Stucco : ; Vinyl Siding : ; Vinyl Siding : ; Vinyl Siding : ; Stucco : ; Vinyl Siding : ; Aluminum Siding : ; Aluminum Siding : ; Aluminum Siding : Vinyl Siding : ; Aluminum Siding : ; Brick Veneer : ; Brick Veneer : ; Brick Veneer : ; Aluminum Siding : ; Brick Veneer : ; Wood Siding : ; Wood Siding : ; Wood Siding : ; Brick Veneer : ; Wood Siding : ; Stucco : ; Stucco : ; Stucco : ; Wood Siding : ; Stucco : ; Vinyl Siding : ; Vinyl Siding : ; Vinyl Siding : ; Stucco : ; Vinyl Siding :; Aluminum Siding : ; Aluminum Siding : ; Aluminum Siding : ; Vinyl Siding : ; Aluminum Siding : ; Brick Veneer : ; Brick Veneer : ; Brick Veneer : ; Aluminum Siding : ; Brick Veneer : ; Wood Siding : ; Wood Siding : ; Wood Siding : ; Brick Veneer : ; Wood Siding : ; Stucco : ; Stucco : ; Stucco : ; Wood Siding : ; Stucco : ; Vinyl Siding : ; Vinyl Siding : ; Vinyl Siding : ; Stucco : ; Vinyl Siding : ; Aluminum Siding:; Aluminum Siding : ; Aluminum Siding : ; Vinyl Siding : ; Aluminum Siding : ; Brick Veneer : ; Brick Veneer : ; Brick Veneer : ; Aluminum Siding : ; Brick Veneer : ; Wood Siding : ; Wood Siding : ; Wood Siding : ; Brick Veneer : ; Wood Siding : ; Stucco :; Stucco : ; Stucco : ; Wood Siding : ; Stucco : ; Vinyl Siding : ; Vinyl Siding : ; Vinyl Siding : ; Stucco : ; Vinyl Siding : ; Aluminum Siding : ; Aluminum Siding : ; Aluminum Siding : ; Vinyl Siding : ; Aluminum Siding : ; Brick Veneer : ; Brick Veneer : ; Brick Veneer : ; Brick Veneer : ; Aluminum Siding : ; Wood Siding : ; Wood Siding : ; Wood Siding : ; Wood Siding : ; Brick Veneer : ; Stucco : ; Stucco : ; Stucco : ; Stucco : ; Wood Siding : ; Vinyl Siding : ; Vinyl Siding : ; Vinyl Siding : ; Vinyl Siding : ; Stucco : ; Aluminum Siding : ; Aluminum Siding : ; Aluminum Siding : ; Aluminum Siding : ; Vinyl Siding : ; Brick Veneer : ; Brick Veneer : ; Brick Veneer : ; Brick Veneer :; Aluminum Siding : ; R-0 (no insulation) : ; R-0 (no insulation) : ; R-0 (no insulation) : ; R-0 (no insulation) : ; Brick Veneer : ; R-5 (1 inch) : ; R-5 (1 inch) : ; R-5 (1 inch) : ; R-5 (1 inch) : ; R-0 (no insulation) : ; R-10 (2 inches) : ; R-10 (2 inches) : ; R-10 (2 inches) : ; R-10 (2 inches) : ; R-5 (1 inch) : ; Stucco : ; Stucco : ; Stucco : ; Stucco : ; R-10 (2 inches) : ; Brick : ; Brick : ; Brick : ; Brick : ; Stucco : ; None : ; None : ; None : ; None : ; Brick : ; Stucco : ; Stucco : ; Stucco : ; Stucco : ; None : ; Brick : ; Brick : ; Brick :; Brick : ; Stucco : ; None : ; None : ; None : ; None : ; Brick : ; Stucco : ; Stucco : ; Stucco : ; Stucco : ; None : ; Brick : ; Brick : ; Brick : ; Brick : ; Stucco : ; None : ; None : ; None : ; None : ; Brick : ; R-0 (no insulation) : ; R-0 (no insulation) : ; R-0 (no insulation) : ; R-0 (no insulation) : ; None : ; R-0 (no insulation) :

\section{Doors Windows}

Doors - Front of house - Number of doors each wall : 1 door; Doors - Front of house - Door Type : Uninsulated wood/wood/wood; Doors - Front of house - Door U-Factor 0.00; Doors - Right side of house - Number of doors each wall : 0 doors; Doors - Right side of house - Door Type : Uninsulated wood/wood/wood; Doors - Right side of house - Door U-Factor : 0.00; Doors - Back of house - Number of doors each wall : 1 door; Doors - Back of house - Door Type : Uninsulated wood/wood/wood; Doors Back of house - Door U-Factor : 0.00; Doors - Left side of house - Number of doors each wall : 1 door; Right : Interior Drapes; Doors - Left side of house - Door Type : Custom door (enter U-Factor below); Back : Interior Drapes; Doors - Left side of house - Door U-Factor : 1.30; Left : Interior Drapes; Windows - Does the house have diff types of windows on each side : No; Single-pane, clear" 15 heat_cool_input windowTypeFront Detailed Doors-Windows windowTypeFront sp-tinted-a radio 0 scna stna "Single-pane, tinted" 16 heat_cool input windowTypeFront Detailed Doors-Windows windowTypeFront dp-clear-a radio 0 scna : ; Single-pane, tinted : ; Double-pane, clear : ; Double-pane, tinted : ; Double-pane, solar-control low-E : ; Double-pane, clear : ; Double-pane, tinted : ; Single-pane, clear : ; Double-pane, solar-control low-E : ; Custom window : ; Single-pane, tinted : ; Double-pane, insulating low-E, argon gas fill : ; Custom window : ; Double-pane, clear : ; Single-pane, clear : ; Custom window : ; Doublepane, tinted : ; Single-pane, tinted : ; Custom window : ; Double-pane, solar-control low-E : ; Double-pane, clear : ; Double-pane, clear : ; Double-pane, tinted : ; Doublepane, tinted : ; Double-pane, solar-control low-E : ; Double-pane, solar-control low-E : ; Double-pane, solar-control low-E, argon gas fill : ; Double-pane, insulating low-E, argon gas fill : ; Double-pane, insulating low-E : ; Single-pane, clear : ; Double-pane, insulating low-E, argon gas fill : ; Single-pane, tinted : ; Triple-pane, insulating low-E, argon gas fill : ; Double-pane, clear : ; U-Factor (0.00:5.00) : 0.00; Double-pane, tinted : 0.00; Solar heat gain coefficient (0.00:1.00) : 0.00; Double-pane, solar-control low-E : 0.00; Window Area Front : 48.02; Double-pane, solar-control low-E, argon gas fill : 48.02; Window Area Right : 20.97; Double-pane, insulating low-E : 20.97; Window Area Back : 30.17 ; Double-pane, insulating low-E, argon gas fill : 30.17; Window Area Left : 57.68; Triple-pane, insulating low-E, argon gas fill : 57.68 ; Movable Insulation Front : 0.00; U-Factor (0.00:5.00) : 0.00; Movable Insulation Right : 0.00; Solar heat gain coefficient (0.00:1.00) : 0.00; Movable Insulation Back : 0.00; Single-pane, clear : Movable Insulation Left : 0.00; Single-pane, tinted : 0.00; Movable Shades Front : Interior Drapes; Double-pane, clear : Interior Drapes; Movable Shades Right : Interior Drapes; Double-pane, tinted : Interior Drapes; Movable Shades Back : Interior Drapes; Double-pane, solar-control low-E : Interior Drapes; Movable Shades Left : Interior Drapes; Double-pane, clear : Interior Drapes; Double-pane, tinted : Interior Drapes; Double-pane, solar-control low-E : Interior Drapes; Double-pane, insulating low-E, argon gas fill : Interior Drapes; Single-pane, clear : Interior Drapes; Single-pane, tinted : Interior Drapes; Double-pane, clear : Interior Drapes; Double-pane, tinted : Interior Drapes; Double-pane, solar-control low-E : Interior Drapes; Double-pane, solar-control low-E, argon gas fill : Interior Drapes; Double-pane, insulating low-E : Interior Drapes; Double-pane, insulating low-E, argon gas fill : Interior Drapes; Triple-pane, insulating low-E, argon gas fill : Interior Drapes; U-Factor (0.00:5.00) : 0.00; Solar heat gain coefficient $(0.00: 1.00): 0.00$; Single-pane, clear : ; Single-pane, tinted : ; Double-pane, clear : ; Double-pane, tinted : ; Double-pane, solar-control low-E : ; Double-pane, clear : ; Double-pane, tinted : ; Double-pane, solar-control low-E : ; Double-pane, insulating low-E, argon gas fill : ; Single-pane, clear : ; Single-pane, tinted : ; Double-pane, clear : ; Double-pane, tinted : ; Double-pane, solar-control low-E : ; Double-pane, solar-control low-E, argon gas fill : ; Double-pane, insulating low-E : ; Doublepane, insulating low-E, argon gas fill : ; Triple-pane, insulating low-E, argon gas fill : ; U-Factor $(0.00: 5.00): 0.00$; Solar heat gain coefficient $(0.00: 1.00): 0.00$;

\section{Attic Roof}

Attic or ceiling type : Unconditioned Attic; Insulation level of the attic floor : R-0 (no insulation); R-0 (no insulation) : ; R-11 (3-5 inches) : ; R-13 (5-6 inches) : ; R-15 (6-7 inches) : ; R-19 (7-9 inches) : ; R-21 (9-10 inches) : ; R-0 (no insulation) : ; R-11 (3-5 inches) : ; R-13 (5-6 inches) : ; R-15 (6-7 inches) : ; R-19 (7-9 inches) : ; R-21 (9-10 inches) : ; R-27 (10-13 inches) : ; R-0 (no insulation) : ; R-11 (3-5 inches) : ; R-13 (5-6 inches) : ; R-15 (6-7 inches) : ; R-19 (7-9 inches) : ; R-21 (9-10 inches) : ; R-27 (10-13 inches) : ; R-0 (no insulation) : ; R-11 (3-5 inches) : ; R-13 (5-6 inches) : ; R-15 (6-7 inches) : ; R-19 (7-9 inches) : ; R-21 (9-10 inches) : ; R-27 (10-13 inches) : ; R-0 (no insulation) : ; R-11 (3-5 inches) : ; R-13 (5-6 inches) : ; R-15 (6-7 inches) : ; R-19 (7-9 inches) : ; R-21 (9-10 inches) : ; R-27 (10-13 inches) : ; R-0 (no insulation) : ; R-0 (no insulation) : ; R-0 (no insulation) : ; R-0 (no insulation) : ; R-0 (no insulation) : ; R-0 (no insulation) : ; R-11 (3-5 inches) : ; R-13 (5-6 inches) : ; R-15 (6-7 inches) : ; R-0 (no insulation) : ; R-11 (3-5 inches) : ; R-13 (5-6 inches) : ; R-15 (6-7 inches) : ; R-19 (7-9 inches) : ; R-21 (9-10 inches) : ; R-0 (no insulation) : ; R-11 (3-5 inches) : ; R-13 (5-6 inches) : ; R-15 (6-7 inches) : ; R-19 (7-9 inches) : ; R-21 (9-10 inches) : ; R-0 (no insulation) : ; R-11 (3-5 inches) : ; R-13 (5-6 inches) : ; R-15 (6-7 inches) : ; R-19 (7-9 inches) : ; R-21 (9-10 inches) : ; R-0 (no insulation) : ; R-11 (3-5 inches) : ; R-13 (5-6 inches) : ; R-15 (6-7 inches) : ; R-19 (7-9 inches) : ; R-21 (9-10 inches) : ; Slider : 0.800; User-entered exterior roof absorptance : 0.800; Slope (or pitch) of roof : $3: 12$ (14 degrees);

\section{Ducts Pipes}

Duct location : Unknown/not applicable; Are the ducts insulated? : No/Don't Know; Are the ducts sealed? : No/Don't Know; Are the boiler pipes insulated? : No/Don't Know; Does the boiler also provide the hot tap water? : No - I have a separate boiler and water heater. ;

\section{Thermostat}

Settings changed during the day and evening : No Change; Standard or Programmable Thermostat : standard; Temperature setting - Heating temperature : 64; Temperature setting - Cooling temperature : 81; Weekdays Heating Day Degrees : 64; Weekdays Heating Day Time : 8; Weekdays Heating Night Degrees : 68; Weekdays Heating Night Time : 17; Weekdays Cooling Day Degrees : 81; Weekdays Cooling Day Time : 8; Weekdays Cooling Night Degrees : 78; Weekdays Cooling Night Time : 17; Weekend/Holiday Heating Day Degrees : 64; Weekend/Holiday Heating Day Time : 8; Weekend/Holiday Heating Night Degrees : 68; Weekend/Holiday Heating Night Time :
17; Weekend/Holiday Cooling Day Degrees : 81; Weekend/Holiday Cooling Day Tin: $\mathbf{8}$; Weekend/Holiday Cooling Night Degrees : 78; Weekend/Holiday Cooling Night 
Time : 17; Temperature setting - Heating temperature : 8; Temperature setting - Cooling temperature : 8; Weekdays Heating Wake degrees : 68; Weekdays Heating Wake Time : 7; Weekdays Heating Away degrees : 64; Weekdays Heating Away Time : 9; Weekdays Heating Evening degrees : 68; Weekdays Heating Evening Time : 19; Weekdays Heating Sleep degrees : 64; Weekdays Heating Sleep Time : 23; Weekdays Cooling Wake degrees : 78; Weekdays Cooling Wake Time : 7; Weekdays Cooling Away degrees : 81; Weekdays Cooling Away Time : 9; Weekdays Cooling Evening degrees : 78; Weekdays Cooling Evening Time : 19; Weekdays Cooling Sleep degrees 81; Weekdays Cooling Sleep Time : 23; Weekend/Holiday Heating Wake degrees : 68; Weekend/Holiday Heating Wake Time : 8; Weekend/Holiday Heating Away degrees : 64; Weekend/Holiday Heating Away Time : 11; Weekend/Holiday Heating Evening degrees : 68; Weekend/Holiday Heating Evening Time : 19; Weekend/Holiday Heating Sleep degrees : 64; Weekend/Holiday Heating Sleep Time : 23; Weekend/Holiday Cooling Wake degrees : 78; Weekend/Holiday Cooling Wake Time : 8; Weekend/Holiday Cooling Away degrees : 81; Weekend/Holiday Cooling Away Time : 11; Weekend/Holiday Cooling Evening degrees : 78; Weekend/Holiday Cooling Evening Time : 19; Weekend/Holiday Cooling Sleep degrees : 81; Weekend/Holiday Cooling Sleep Time : 23;

\section{Heating Equipment}

Type of heating system : Room (through-the-wall) gas furnace; Heating system capacity : 60000; Heating system efficiency : $\mathbf{5 0 . 0 0 ; ~ Y e a r ~ h e a t i n g ~ s y s t e m ~ i n s t a l l e d ~ : ~}$ 1970; Percentage of the house's floor area heated by a central or room heating system : 19; Percentage of the house's heating needs supplied by a wood burning stove or portable heater : 37 ;

\section{Cooling Equipment}

Type of cooling system : No Cooling Equipment; Cooling system capacity : 0; Cooling system efficiency : 0.00; Year cooling system installed : 1970; Percentage of the house's floor area cooled by the cooling system : 100; Hours room air conditioner is on during an average day in the cooling season : None; Number of months room air conditioner is on during an average cooling season ? : None; Does the house have ceiling fans? : Yes; Number of ceiling fans : 2; Does the house have a whole-house fan? No; Hours per day the whole-house fan is used : $\mathbf{0}$; Months per year the whole-house fan is used : $\mathbf{0}$; Does the house have portable fans? : Yes; Number of portable fans : 1

\section{Water Heating}

Water heater fuel : Piped Natural Gas; Year purchased : 1972; Does occupant pay for water heater fuel? : Yes; Is an adult at home on weekdays? : Yes; Energy Factor : 0.47; Recovery Efficiency : 0.76; Rated Input : 38000.00; Storage tank capacity (gallons) : 40; Temperature Setting : Medium-Low; Water heater location : Outdoors;

\section{Lighting}

Kitchen : 2; Kitchen Bulb Type : Halogen Tochiere; Kitchen Number of bulbs in fixture : 1^1;2^1; Kitchen Sum of wattages for all bulbs in fixture : 1^95;2^95; Kitchen Usage (Hrs/day) : 1; Dining Room : 0; Dining Room Bulb Type : ; Dining RoomNumber of bulbs in fixture : ; Dining RoomSum of wattages for all bulbs in fixture : ; Dining RoomUsage (Hrs/day) : ; Living Room : 3; Living Room Bulb Type : Halogen Tochiere; Living Room Number of bulbs in fixture : 1^1;2^1;3^1; Living Room Sum of

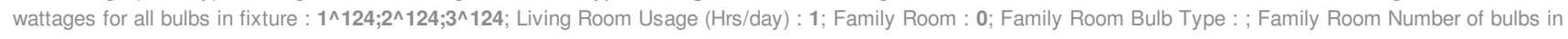
fixture : ; Family Room Sum of wattages for all bulbs in fixture : ; Family Room Usage (Hrs/day) : ; Master Bedroom : 3; Master Bedroom Bulb Type : Halogen Tochiere; Master Bedroom Number of bulbs in fixture : $\mathbf{1}^{\wedge} 1 ; 2^{\wedge} 1 ; 3^{\wedge} 1$; Master BedroomSum of wattages for all bulbs in fixture : $\mathbf{1}^{\wedge} 93 ; 2^{\wedge} 93 ; 3^{\wedge} 93 ;$ Master Bedroom Usage (Hrs/day) : 1 Hall : 0; Hall Bulb Type : ; Hall Number of bulbs in fixture : ; Hall Sum of wattages for all bulbs in fixture : ; Hall Usage (Hrs/day) : ; All Bedrooms : 1; All Bedrooms Bulb Type : Halogen Tochiere; All Bedrooms Number of bulbs in fixture : 1^1; All Bedrooms Sum of wattages for all bulbs in fixture : 1^94; All Bedrooms Usage (Hrs/day) : 1; All Bathrooms : 4; All Bathrooms Bulb Type : Halogen Tochiere; All Bathrooms Number of bulbs in fixture : $1^{\wedge} 1 ; 2^{\wedge} 1 ; 3^{\wedge} 1 ; 4^{\wedge} 1 ;$ All Bathrooms Sum of wattages for all bulbs

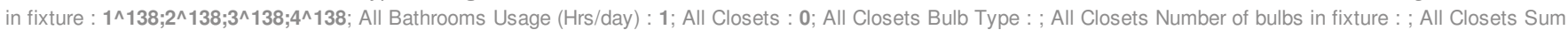
of wattages for all bulbs in fixture : ; All Closets Usage (Hrs/day) : ; Utility Room : 1; Utility Room Bulb Type : ; Utility Room Number of bulbs in fixture : ; Utility Room Sum of wattages for all bulbs in fixture : ; Utility Room Usage (Hrs/day) : ; Garage : 0; Garage Bulb Type : ; Garage Number of bulbs in fixture : ; Garage Sum of wattages for all bulbs in fixture : : Garage Usage (Hrs/day) : : Outdoor Lighting : 5; Outdoor Lighting Bulb Type : Halogen Tochiere; Outdoor Lighting Number of bulbs in fixture : $1^{\wedge} 1 ; 2^{\wedge} 1 ; 3^{\wedge} 1 ; 4^{\wedge} 1 ; 5^{\wedge} 1$; Outdoor Lighting Sum of wattages for all bulbs in fixture : $1^{\wedge} 110 ; 2^{\wedge} 110 ; 3^{\wedge} 110 ; 4^{\wedge} 110 ; 5^{\wedge} 110$; Outdoor Lighting Usage (Hrs/day) : 1 ; Other : 0; Other Bulb Type : ; Other Number of bulbs in fixture : ; Other Sum of wattages for all bulbs in fixture : ; Other Usage (Hrs/day) : ;

\section{Refrigerators Freezers}

Year made : 1972; Size : Large (19-21 cu ft); Type : Large (19-21 cu ft); Energy Star : No; Year made : present; Size : present; Type : present; Energy Star : No; Year made : present; Size : present; Type : present; Energy Star : No; Year made : present; Size : present; Type : present; Year made : present; Size : present; Type : present;

\section{Cooking Dishwashing}

Stove fuel : Natural Gas or Propane; hours per day stove used : 1 hour; Pilot Light : No; Oven fuel : Natural Gas or Propane; Hours per week oven used : 2 hours; Pilot Light : No; Does house have/use a dishwasher : Yes; Energy Start Qualified : No; Loads washed per week : 4;

\section{Laundry}

Does house have/use a clothes washer? : Yes; ENERGY STAR Qualified : No; Hot/Warm : 2; Hot/Cold : 0; Warm/Warm : 3; Warm/Cold : 2; Cold/Cold : 0; Dryer fuel : Electricity; Number of loads dried per week : 7 ;

\section{HotTubs Spas Pumps}

How many hours/day does the pool pump run? : House doesn't have a pool pump; How many months of the year does the pool pump run? : 0 ; Is there a pool heater? No; How is the spa heated? : House doesn't have a spa/hot tub; If spa is heated only when it is being used, how many hours per week is it used?" 6 major appliance input sumpPumpSize Detailed HotTubs-Spas-Pumps sumpPumpSize sump-pump-size 0 values:1-4 What is the size of the sump pump? 7 major_appliance_input : $\mathbf{0}$; What is the size of the sump pump? : House doesn't have a sump/sewage pump; How many hours/year does the sump operate? : 5 hours/year; Indicate the vertical distance that water is lifted. : House doesn't have a well pump; Combined pump and motor efficiency : Typical - 40\%; Is house water pressure provided by gravity or pump? : Pump; How much water is used outdoors? : Roughly 5 min/day with garden hose;

\section{Entertainment}

Number of Units : 1; Average Per-unit Use : 2; Unit of Time : Hours; Unit of Calendar : Day; Energy Star? : No; Number of Units : 0; Average Per-unit Use : 2; Unit of Time : Hours; Unit of Calendar : Day; Number of Units : 0; Average Per-unit Use : 2; Unit of Time : Hours; Unit of Calendar : Day; Number of Units : 0; Average Per-unit Use : 2; Unit of Time : 2; Unit of Calendar : Day; Number of Units : 0; Average Per-unit Use : 2; Unit of Time : Hours; Unit of Calendar : Day; Number of Units : 1; Average Per-unit Use : 4; Unit of Time : Hours; Unit of Calendar : Week; Energy Star? : No; Number of Units : 1; Average Per-unit Use : 2; Unit of Time : Hours; Unit of Calendar : Week; Energy Star? : No; Number of Units : 1; Average Per-unit Use : 1; Unit of Time : Minutes; Unit of Calendar : Day; Number of Units : 0; Average Per-unit Use : 0; Unit of Time : Minutes; Unit of Calendar : Day; Number of Units : 1; Average Per-unit Use : 1; Unit of Time : Hours; Unit of Calendar : Day; Number of Units : 1; Average Per-unit Use : 2; Unit of Time : Hours; Unit of Calendar : Week; Number of Units : 1; Average Per-unit Use : 30; Unit of Time : Minutes; Unit of Calendar : Week; Number of Units : 1; Average Per-unit Use : 30; Unit of Time : Minutes; Unit of Calendar : Week; Energy Star : No; Number of Units : 1; Average Per-unit Use : 2; Unit of Time : Hours; Unit of Calendar: Week;

\section{Home Office}

Number of Units : 1; Average Per-unit Use : 5; Unit of Time : Hours; Unit of Calendar : Day; Number of Units : 1; Average Per-unit Use : 5; Unit of Time : Hours; Unit of Calendar : Day; Number of Units : 0; Average Per-unit Use : 0; Unit of Time : Minutes; Unit of Calendar : Day; Number of Units : 0; Average Per-unit Use : 1; Unit of Time : Hours; Unit of Calendar: Week; Number of Units : 1; Average Per-unit Use : 1; Unit of Time : Hours; Unit of Calendar : Week; Number of Units : 1; Average Per-unit Use : 5; Unit of Time : Hours; Unit of Calendar: Day; Number of Units : 0; Average Per-unit Use : 4; Unit of Time : Minutes; Unit of Calendar : Day; Energy Star : No; Number of Units : 0; Average Per-unit Use : 4; Unit of Time : Minutes; Unit of Calendar : Dayglmber of Units : 0; Average Per-unit Use : 30; Unit of Time : Minutes; Unit of Calendar Day; Average Per-unit Use : 0; Unit of Time : Hours; Unit of Calendar : Day; 


\section{Miscellaneous Kitchen Equipment}

Bottled Water (With heating or chilling ability) : Day; Energy Star Qualified : No; Instant Hot Water : No; Number of Units : 0; Average Per-unit Use : 1; Unit of Time : Hours; Unit of Calendar : Week; Number of Units : 1; Average Per-unit Use : 30; Unit of Time : Minutes; Unit of Calendar : Day; Average Per-unit Use : 1; Unit of Time : Hours; Unit of Calendar : Day; Number of Units : 0; Average Per-unit Use : 30; Unit of Time : Minutes; Unit of Calendar : Day; Average Per-unit Use : 1; Unit of Time : Hours; Unit of Calendar : Day; Number of Units : 0; Average Per-unit Use : 0; Unit of Time : Minutes; Unit of Calendar : Week; Number of Units : 0; Average Per-unit Use : 0; Unit of Time : Hours; Unit of Calendar : Month; Number of Units : 0; Average Per-unit Use : 1; Unit of Time : Hours; Unit of Calendar : Week; Number of Units : 1; Average Per-unit Use : 1; Unit of Time : Minutes; Unit of Calendar : Day; Number of Units : 0; Average Per-unit Use : 0; Unit of Time : Hours; Unit of Calendar : Week; Number of Units : 1; Average Per-unit Use : 6; Unit of Time : Minutes; Unit of Calendar : Day; Number of Units : 0; Average Per-unit Use : 4; Unit of Time : Minutes; Unit of Calendar : Day; Average Per-unit Use : Day; Unit of Time : Minutes; Unit of Calendar : Day;

\section{Other Appliances}

Number of Units : 0; Number of Units : 0; Average Per-unit Use : 1; Unit of Time : Hours; Unit of Calendar : Week; Number of Units : 1; Average Per-unit Use : 1; Unit of Time : Hours; Unit of Calendar : Week; Number of Units : 0; Average Per-unit Use : 24; Unit of Time : Hours; Unit of Calendar : Day; Number of Units : 0; Average Per-unit Use : 1; Unit of Time : Hours; Unit of Calendar : Day; Months in the year : 4; Number of Units : 2; Number of Units : 0; Average Per-unit Use : 24; Unit of Time : Hours; Unit of Calendar : Day; Energy Star : No; Number of Units : 1; Number of Units : 1; Average Per-unit Use : 3; Unit of Time : Hours; Unit of Calendar : Day; Months in year : 4; Number of Units : 0; Average Per-unit Use : 1; Unit of Time : Hours; Unit of Calendar : Day; Months in year : 4; Number of Units : 0; Average Per-unit Use : 24; Unit of Time : Hours; Unit of Calendar : Day; Energy Star : No; Number of Units : 0; Average Per-unit Use : 8; Unit of Time : Minutes; Unit of Calendar : Day; Number of Units : 1; Average Per-unit Use : 7; Unit of Time : Minutes; Unit of Calendar : Day; Number of Units : 0; Average Per-unit Use : 1; Unit of Time : Hours; Unit of Calendar : Day; Months in year : 4; Number of Units : 0; Average Per-unit Use : 24; Unit of Time : Hours; Unit of Calendar : Day; Number of Units : 1; Average Per-unit Use : 20; Unit of Time : Minutes; Unit of Calendar : Week; Number of Units : 0; Average Per-unit Use : 2; Unit of Time : Hours; Unit of Calendar : Day; Months in year : 4; Number of Units : 0; Number of Units : 0; Average Per-unit Use : 1; Unit of Time : Hours; Unit of Calendar : Day; Months in year : 4; Number of Units : 0; Average Per-unit Use : 6; Unit of Time : Hours; Unit of Calendar : Week; Number of Units : 0; Name : ; Average Per-unit Use : 0; Unit of Time : Minutes; Unit of Calendar : Day; Watts : ; Number of Units : 0; Name : ; Average Per-unit Use : 0; Unit of Time : Minutes; Unit of Calendar : Day; Watts : ; Number of Units : 0; Name : ; Average Per-unit Use : 0; Unit of Time : Minutes: Unit of Calendar : Day; Watts : ; Number of Units : 0; Name : ; Average Per-unit Use : 0; Unit of Time : Minutes; Unit of Calendar : Day; Watts : ; Number of Units : 0; Name : ; Average Per-unit Use : 0; Unit of Time : Minutes; Unit of Calendar : Day; Watts : ;

\section{House Shape Size}

Conditioned floor area (all stories combined) ?: 1113; Direction faced by front of house : North; Stories above ground level : 1; Interior floor-to-ceiling height : 8 feet; Rectangle : ; L-Shape : ; Front S-Shape : ; Back S-Shape : ; T-Shape : ; U-Shape : ; Split- or Tri- Level : ; Townhouse : ; Front door is on Top Side : ; Front door is on Right Side : ; Front door is on Bottom Side : ; Front door is on Left Side : ; Length of the house (from front to back) $\mid r$ : 25.84; Width of the house (from left to right) $\mid r$ : 43.07; Front door is on Top Side : 43.07; Front door is on Right Side : 43.07; Front door is on Bottom Side : ; Front door is on Left Side : ; Side 1 Dimension : 10.00; Side 2 Dimension : 10.00; Side 3 Dimension : 43.07; Side 4 Dimension : 25.84; Front door is on Top Side : 25.84; Front door is on Right Side : 25.84; Front door is on Bottom Side : ; Front door is on Left Side : ; Side 1 Dimension : 10.00; Side 2 Dimension : 10.00; Side 3 Dimension : 10.00; Side 4 Dimension : 10.00; Side 3 Dimension : 43.07; Side 4 Dimension : 25.84; Front door is on Top Side : 25.84; Front door is on Right Side : 25.84; Front door is on Bottom Side : ; Front door is on Left Side : ; Side 1 Dimension : 10.00; Side 2 Dimension : 10.00; Side 3 Dimension : 10.00; Side 4 Dimension : 10.00; Side 3 Dimension : 43.07; Side 4 Dimension : 25.84 ; Front door is on Top Side : 25.84; Front door is on Right Side : 25.84; Front door is on Bottom Side : ; Front door is on Left Side : ; Side 1 Dimension : 43.07; Side 2 Dimension : 10.00; Side 3 Dimension : 10.00; Side 4 Dimension : 10.00; Side 3 Dimension : 25.84; Side 4 Dimension : 10.00; Front door is on Top Side : 10.00; Front door is on Right Side : 10.00; Front door is on Bottom Side : ; Front door is on Left Side : ; Side 1 Dimension : 10.00; Side 2 Dimension : 10.00; Side 3 Dimension : 10.00; Side 4 Dimension : 43.07; Side 3 Dimension : 25.84; Side 4 Dimension : 10.00; Front door is on Top Side : 10.00; Front door is on Right Side : 10.00; Front door is on Bottom Side : ; Front door is on Left Side : ; Side 1 Dimension : 10.00; Side 2 Dimension : 10.00; Side 3 Dimension : 43.07; Side 4 Dimension : 25.84; Front door is on Top Side : 25.84; Front door is on Right Side : 25.84; Front door is on Bottom Side : ; Front door is on Left Side : ; Front door is on Right Side : ; Front door is on Bottom Side : ; Front door is on Left Side : ; Length of the house (from front to back) $\backslash r: 25.84$; Width of the house (from left to right) $\backslash \mathrm{r}: \mathbf{4 3 . 0 7}$;

\section{Skylights}

Single-pane, clear : : Single-pane, tinted : : Double-pane, clear : ; Double-pane, tinted : ; Double-pane, solar-control low-E : ; Double-pane, clear : ; Double-pane, tinted : ; Double-pane, solar-control low-E : ; Double-pane, insulating low-E, argon gas fill : ; Single-pane, clear : ; Double-pane, clear : ; Double-pane, tinted : ; Double-pane, solarcontrol low-E : ; Double-pane, solar-control low-E, argon gas fill : ; Double-pane, insulating low-E : ; Double-pane, insulating low-E, argon gas fill : ; Triple-pane, insulating low-E, argon gas fill : ; Skylight U-Factor : $\mathbf{0 . 0 0}$; Skylight Solar heat gain coefficient : $\mathbf{0 . 0 0}$; Enter the R-value of movable skylight insulation : $\mathbf{0 . 0 0}$; Select the type of movable interior skylight shades : None; Skylight size : 0.00 ; 


\section{YEARLY ENERGY COSTS}

Providing more details will make your results more accurate.

$\begin{array}{ll}\text { Existing Home } & \$ 1,470 \\ \text { With Upgrades } & \$ 1,627\end{array}$

\begin{tabular}{|c|c|c|c|c|c|c|c|}
\hline & Total & Heating & Cooling & Hot Water & $\begin{array}{c}\text { Large } \\
\text { Appliances }\end{array}$ & $\begin{array}{c}\text { Small } \\
\text { Appliances }\end{array}$ & Lighting \\
\hline Existing Home & $\$ 1,470$ & $\$ 145$ & $\$ 11$ & $\$ 268$ & $\$ 587$ & $\$ 215$ & $\$ 244$ \\
\hline $\begin{array}{l}\text { With } \\
\text { Upgrades }\end{array}$ & $\$ 1,627$ & $\$ 682$ & $\$ 11$ & $\$ 204$ & $\$ 397$ & $\$ 215$ & $\$ 118$ \\
\hline Savings & $\$-157$ & $\$-537$ & $\$ 0$ & $\$ 64$ & $\$ 190$ & $\$ 0$ & $\$ 126$ \\
\hline
\end{tabular}

Important Note: These are initial estimates only, and results may vary. If the owner has not already done so, we strongly recommend that they retain a professional energy auditor to develop a detailed work scope and budget for improving the home. We also recommend the Home Performance with ENERGY STAR program when considering home improvements. 
YEARLY WHOLE HOUSE RESULTS

\section{Existing Home With Upgrades}

\begin{tabular}{|c|c|c|c|c|c|}
\hline \multirow{4}{*}{ Whole House } & Energy Bill & $\$ 1,470$ & $\$ 1,627$ & $\$-157$ & $-10.7 \%$ \\
\hline & Electricity & $5837 \mathrm{kWh}$ & $3346 \mathrm{kWh}$ & $2491 \mathrm{kWh}$ & $42.7 \%$ \\
\hline & Natural Gas & 495 Therms & 948 Therms & -453 Therms & $-91.5 \%$ \\
\hline & Emissions & 8695 CO2 & $12744 \mathrm{CO} 2$ & $-4049 \mathrm{lb} . \mathrm{CO}_{2}$ & $-46.6 \%$ \\
\hline \multirow{3}{*}{ Heating } & Energy Bill & $\$ 145$ & $\$ 682$ & $\$-537$ & $-370.3 \%$ \\
\hline & Natural Gas & 114 Therms & 537 Therms & -423 Therms & $-371.1 \%$ \\
\hline & Emissions & $1332 \mathrm{lb} . \mathrm{CO}_{2}$ & $6274 \mathrm{lb} . \mathrm{CO}_{2}$ & $-4942 \mathrm{lb} . \mathrm{CO}_{2}$ & $-371 \%$ \\
\hline \multirow{3}{*}{ Cooling } & Energy Bill & $\$ 11$ & $\$ 11$ & $\$ 0$ & $0 \%$ \\
\hline & Electricity & $75 \mathrm{kWh}$ & $75 \mathrm{kWh}$ & $0 \mathrm{kWh}$ & $0 \%$ \\
\hline & Emissions & $37 \mathrm{lb} . \mathrm{CO}_{2}$ & $37 \mathrm{lb} . \mathrm{CO}_{2}$ & $\mathrm{O} \mathrm{lb} \cdot \mathrm{CO}_{2}$ & $0 \%$ \\
\hline \multirow{3}{*}{ Hot Water } & Energy Bill & $\$ 268$ & $\$ 204$ & $\$ 64$ & $23.9 \%$ \\
\hline & Natural Gas & 211 Therms & 161 Therms & 50 Therms & $23.7 \%$ \\
\hline & Emissions & $2465 \mathrm{lb} . \mathrm{CO}_{2}$ & $1880 \mathrm{lb} . \mathrm{CO}_{2}$ & $585 \mathrm{lb} . \mathrm{CO}_{2}$ & $23.7 \%$ \\
\hline \multirow{4}{*}{$\underline{\text { Large Appliances }}$} & Energy Bill & $\$ 587$ & $\$ 397$ & $\$ 190$ & $32.4 \%$ \\
\hline & Electricity & $2574 \mathrm{kWh}$ & $957 \mathrm{kWh}$ & 1617 kWh & $62.8 \%$ \\
\hline & Natural Gas & 170 Therms & 250 Therms & -80 Therms & $-47.1 \%$ \\
\hline & Emissions & $3270 \mathrm{lb} . \mathrm{CO}_{2}$ & $3398 \mathrm{lb} . \mathrm{CO}_{2}$ & $-128 \mathrm{lb} . \mathrm{CO}_{2}$ & $-3.9 \%$ \\
\hline \multirow{3}{*}{ Small Appliances } & Energy Bill & $\$ 215$ & $\$ 215$ & $\$ 0$ & $0 \%$ \\
\hline & Electricity & $1493 \mathrm{kWh}$ & $1493 \mathrm{kWh}$ & $0 \mathrm{kWh}$ & $0 \%$ \\
\hline & Emissions & $745 \mathrm{lb} . \mathrm{CO}_{2}$ & $745 \mathrm{lb} . \mathrm{CO}_{2}$ & $\mathrm{O} \mathrm{lb} . \mathrm{CO}_{2}$ & $0 \%$ \\
\hline \multirow{3}{*}{ Lighting } & Energy Bill & $\$ 244$ & $\$ 118$ & $\$ 126$ & $51.6 \%$ \\
\hline & Electricity & $1695 \mathrm{kWh}$ & $821 \mathrm{kWh}$ & 874 kWh & $51.6 \%$ \\
\hline & Emissions & $846 \mathrm{lb} . \mathrm{CO}_{2}$ & $410 \mathrm{lb} . \mathrm{CO}_{2}$ & $436 \mathrm{lb} . \mathrm{CO}_{2}$ & $51.5 \%$ \\
\hline
\end{tabular}

Heating electricity values include fan or pumping energy for homes that have forced-air or water-based heating systems powered by circulation pumps. The values for Hot Water include taps and faucets only; the energy consumed by the water heater to supply hot water for appliances such as clothes washers and dishwashers is included instead in the rows for those appliances. 
YEARLY HEATING AND COOLING RESULTS

Show Details

Total Cost

\begin{tabular}{lr} 
Cost & $\$ 156$ \\
Heating & $\$ 145$ \\
Cooling & $\$ 11$ \\
& \\
& \multicolumn{2}{c}{ Total Energy }
\end{tabular}

Energy Use

114 therms75 kWh

Heating

114 therms

Cooling

$75 \mathrm{kWh}$

Notes: this house is $37 \%$ heated by wood fuel.

$19 \%$ of the floor area is heated and $100 \%$ cooled.

Heating electricity values include fan or pumping energy for homes that have forced-air or water-based heating systems powered by circulation pumps.

What if my results don't match my energy bill?

\section{$\because$ HOME ENERGY SAVER}

YEARLY LARGE APPLIANCES AND WATER HEATING RESULTS

Show Details

\begin{tabular}{l|r} 
Appliance & $\begin{array}{r}\text { Total } \\
\text { Cost }\end{array}$ \\
\hline First Refrigerator & $\$ 124$ \\
Stove & $\$ 42$ \\
Oven & $\$ 14$ \\
Clotheswasher & $\$ 139$ \\
Clothesdryer & $\$ 210$ \\
\hline Dishwasher & $\$ 59$ \\
\hline Hot Water: Taps and & $\$ 268$ \\
Faucets & \\
Totals & $\$ 855$
\end{tabular}

Equipment energy is the energy used by motors, heating elements, and burners inside your appliances. This number excludes the energy consumed by your water heater to supply hot water for appliances such as clothes washers and dishwashers (which is included instead in the rows for those appliances).

What if my results don't match my energy bill? 
YEARLY SMALL APPLIANCES RESULTS

Show Details 2

$\begin{array}{lrr}\text { Category } & \text { Energy Use } & \text { Energy Costs } \\ \text { Entertainment } & 345 \mathrm{kWh} & \mathbf{\$ 5 0} \\ \text { HomeOffice } & 361 \mathrm{kWh} & \mathbf{\$ 5 2} \\ \text { Kitchen } & 470 \mathrm{kWh} & \mathbf{\$ 6 8} \\ \text { Other } & 285 \mathrm{kWh} & \mathbf{\$ 4 1}\end{array}$

What if my results don't match my energy bill?

\section{H. HOME ENERGY SAVER}

YEARLY LIGHTING RESULTS

Here is the calculated Yearly lighting bill based on the inputs you provided:

Show Details 2

\begin{tabular}{lrr} 
Room & Energy Use & Energy Costs \\
\hline All Bathrooms & $404 \mathrm{kwh}$ & $\mathbf{\$ 5 8}$ \\
All Bedrooms & $34 \mathrm{kwh}$ & $\mathbf{\$ 5}$ \\
Kitchen & $208 \mathrm{kwh}$ & $\mathbf{\$ 3 0}$ \\
Living Room & $273 \mathrm{kwh}$ & $\mathbf{\$ 3 9}$ \\
Master Bedroom & $102 \mathrm{kwh}$ & $\mathbf{\$ 1 5}$ \\
Outdoor Lighting & $600 \mathrm{kwh}$ & $\mathbf{\$ 8 6}$ \\
Utility Room & $74 \mathrm{kwh}$ & $\mathbf{\$ 1 1}$
\end{tabular}

What if my results don't match my energy bill? 
UPGRADE RECOMMENDATIONS SUMMARY

Visit 'Recommendations' to see more information on each upgrade.

\begin{tabular}{|c|c|c|c|c|c|}
\hline $\begin{array}{l}\text { Yearly } \\
\text { Savings }\end{array}$ & $\frac{\text { Estimated }}{\text { Added Cost }}$ & $\frac{\text { How Much is }}{\text { Too Much? }}$ & $\begin{array}{l}\text { Simple } \\
\text { Payback }\end{array}$ & $\frac{\text { Estimated }}{\text { ROI }}$ & $\frac{\text { Emissions }}{\left.\text { (lbs. } \mathrm{CO}_{2}\right)}$ \\
\hline
\end{tabular}

\section{Total for}

recommended

$\$ 385$

$\$ 409$

$\$ 9625$

$-3$

$10000 \%$

$-4049$

upgrades

Important Note: These are initial estimates only, and results may vary. If the owner has not already done so, we strongly recommend that they retain a professional energy auditor to develop a detailed work scope and budget for improving the home. We also recommend the Home Performance with ENERGY STAR program when considering home improvements

\section{Upgrades Requiring Investment}

1. Indoor lights

2. Electric clothes dryer

3. Clothes washer

4. Refrigerator

5. Ceiling fan

6. Gas water heater

7. Well pump

8. Dishwasher
Other benefits that often come along with these energy-saving upgrades

- Fluorescent lamps last several times longer than ordinary incandescent bulbs, which saves you the time and expense of replacing bulbs when they burn out.

- Natural gas clothes dryers reduce your home's peak load on the power grid compared to an electric dryer.

- ENERGY STAR® clothes washers can reduce water use significantly, leave the clothes drier thus reducing drying time and energy consumption, and reduce wear and tear on clothes.

- Energy-efficient refrigerators are quieter, run less often, release less heat into your kitchen, and keep their contents cool longer during power outages.

- Ceiling fans mix the air in your home more effectively, creating more even temperatures and a more comfortable home.During the cooling season, ceiling fans create air movement that makes you feel cooler, which in turn allows you to raise your air conditioner thermostat setting, reducing your cooling bill.Energy efficient ceiling fans add less heat to the inside of your home during the cooling season.

- Efficient gas-fired water heaters may hold their temperature longer following power interruptions and operate more safely.

- None available.

- Some ENERGY STAR dishwashers reduce water use and/or have shorter run times. 


\section{UPGRADE RECOMMENDATIONS ?}

What efficiency level would you like to model for the initial selection of upgrades?

EnergyStar

What simple payback period would you like to use for selecting 10 * upgrades?

Rows that are dimmed are not included in the calculated values for the retrofit package.

To include them check their boxes and recalculate.

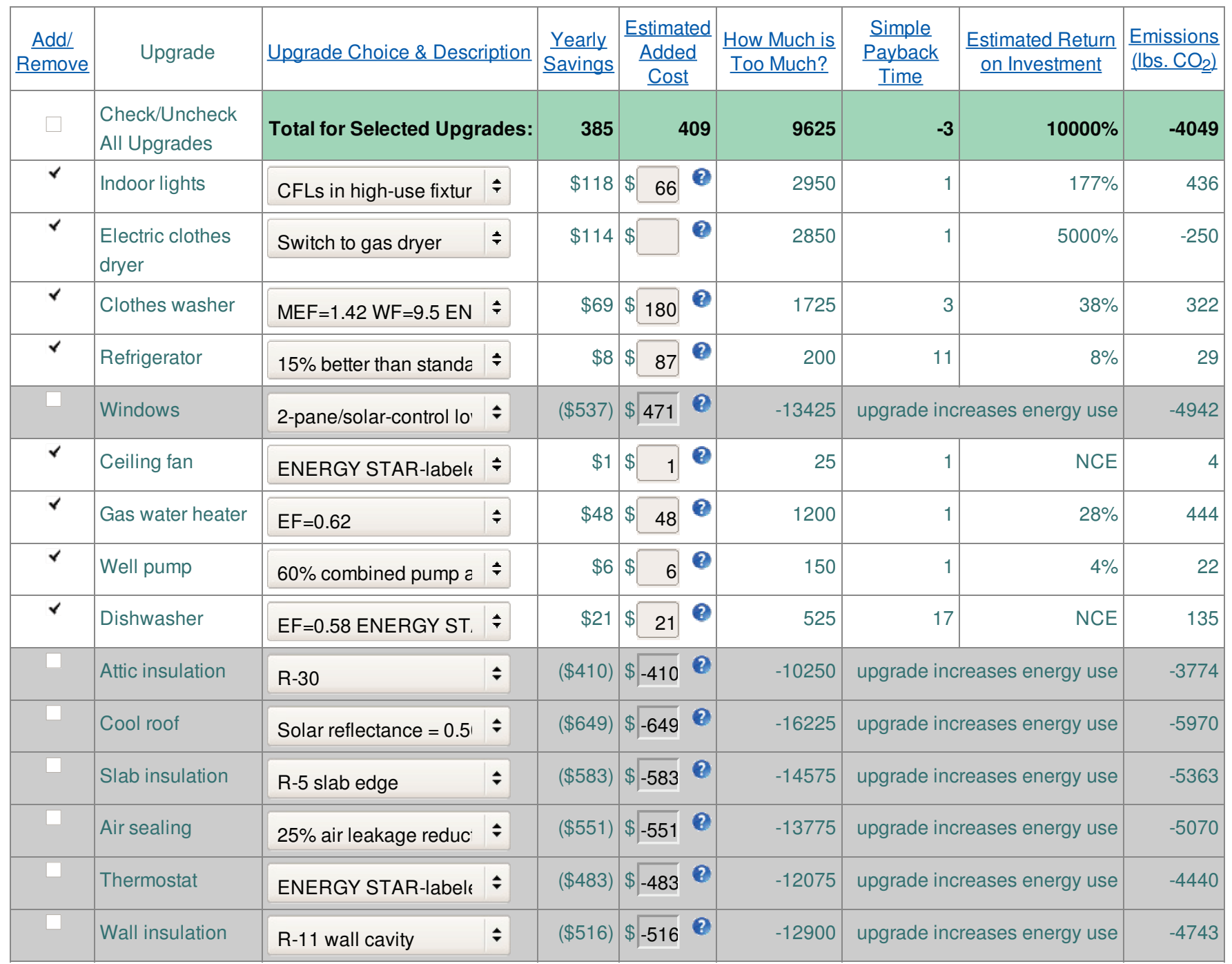

Important Note: These are initial estimates only, and results may vary. If the owner has not already done so, we strongly recommend that they retain a professional energy auditor to develop a detailed work scope and budget for improving the home. We also recommend the Home Performance with ENERGY STAR program when considering home improvements.

NCE $=$ Not Cost Effective. This upgrade will not pay for itself in your situation. There may be other reasons, such as improved comfort, to implement the upgrade, or it could be made more cost-effective if the investment cost is reduced.

Note: Each of the upgrades in the table above are evaluated in isolation from the others. If the efficiency level is changed for one upgrade, its potential impact on other upgrades will not be counted in the row-by-row estimates. However, these kinds of interactions are included in the "package" totals associated with the whole-house totals and chart at the top of the page, for the upgrades selected as part of the package. For example, if the furnace efficiencies are raised, the energy savings from wall insulation will not change in the row estimate, but the incremental savings from including insulation in the package will be less due to the more efficient furnace's impact on reducing the energy required to make up heat losses through the wall (there is less energy being used, so less to save). 


\section{DETAILED UPGRADE RECOMMENDATIONS REPORT}

This is a printable report of the upgrades selected for the home. These upgrades have the potential to save $\$-157$ each year on the utility bill.

Upgrade Package Summary: Estimate Yearly Bill Savings:

Estimated Lifetime Energy Savings:

Estimated Added Cost:

Maximum Price for 10 Year Payback:

Return on Investment:

Upgrade Pays for Itself in:

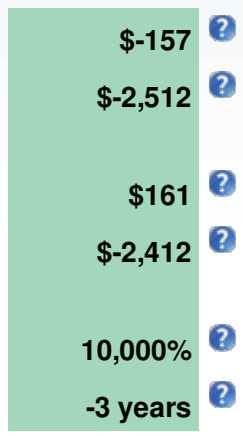

You selected the following upgrades:

- Replace high use incandescent lamps with compact fluorescent lamps

- When replacing your electric clothes dryer, switch to natural gas model

- When replacing your clothes washer, choose an ENERGY STAR-labeled model

- When replacing your main refrigerator, choose an ENERGY STAR-labeled model

- When replacing your ceiling fan, choose an ENERGY STAR-labeled model

- When replacing your gas water heater, choose an energy efficient model

- When replacing your well pump, choose an energy efficient model

- When replacing your dishwasher, choose an ENERGY STAR-labeled model

Note: The economic benefits for each of the upgrades below are evaluated in isolation from the other upgrades. If the efficiency level is changed for one upgrade, its potential impact on other upgrades will not be counted in the individual upgrade estimates. However, these kinds of interactions are included in the "package" totals associated with the whole-house totals and chart at the top of the page (above). For example, if the furnace efficiency is increased, the energy savings from wall insulation will not change in the table below, but the incremental savings from including insulation in the package will be less due to the more efficient furnace's impact on reducing the energy required to make up heat losses through the wall (there is less energy being used, so less to save).

\section{Replace high use incandescent lamps with compact fluorescent lamps}

Economic Benefits:

Estimate Yearly Bill Savings:

Estimated Lifetime Energy

Savings:

Estimated Added Cost:

Maximum Price for 10 Year

Payback:

Return on Investment:

Upgrade Pays for Itself in:

Additional Benefits:

Fluorescent lamps last several times longer than ordinary incandescent bulbs, which saves you the time and expense of replacing bulbs when they burn out.

\section{Upgrade Description:}

Replace high-use incandescent lamps with compact fluorescent lamps. These units can save up to $75 \%$ of the energy used by an ordinary incandescent bulb.

\section{Purchasing Tips:}

- Compare the light output in Lumens of the bulb you are replacing to ensure you are using the appropriate CFL.Most CFLs list their light output and equivalent incandescent wattage on their package.

- CFLs are available in many shapes and sizes, which will allow replacing nearly any incandescent bulb.

- When buying new light fixtures, look for ENERGY STAR qualified models

- CFLs are a good investment for lights that are used 2-3 hours per day on 106 
More Information:

- ENERGY STAR qualifying lighting product list

- General information about lighting from DOE

When replacing your electric clothes dryer, switch to natural gas model

\section{Economic Benefits:}

Estimate Yearly Bill Savings:

Estimated Lifetime Energy

Savings:

Estimated Added Cost:

Maximum Price for 10 Year

Payback:

Return on Investment:

Upgrade Pays for Itself in:
$\$ 1,824$

$\$ 0$

$\$ 2,850$

$5,000 \%$

1 year

Additional Benefits:

Natural gas clothes dryers reduce your home's peak load on the power grid compared to an electric dryer.

\section{Upgrade Description:}

When replacing your electric clothes dryer, select a natural gas model. In many situations, this willreduce your overall energy bill because natural gas tends to cost less than electricity, for the same heating value.

Note: Our calculations bill savings, typical upgrade costs, and cost-effectiveness are for a minimum-efficiency natural gas dryer model. The defaultupgrade cost provided here assumes that a natural gas connection is available at your clothes dryer. If this is not the case, be sure to include the costof extending

\section{Purchasing Tips:}

- To use a gas dryer, your laundry room must have a gas hookup, with proper connections and safe venting of the gas's exhaust, in addition to an electrical outlet

- Look for a dryer with a moisture sensor, and use the dryness settings rather than timed drying.

- When replacing your clothes washer, choose a model with high-speed spin cycles. This feature removes more water from clothes, which reduces the energy and time required for drying

More Information:

- General Information from DOE

- Laundry tips from ACEEE

- Information from the California Energy Commission

\section{When replacing your clothes washer, choose an ENERGY STAR-labeled model}

\section{Economic Benefits:}

Estimate Yearly Bill Savings:

Estimated Lifetime Energy

Savings:

Estimated Added Cost:

Maximum Price for 10 Year

Payback:

Return on Investment:

Upgrade Pays for Itself in:

\section{Additional Benefits:}

ENERGY STAR® clothes washers can reduce water use significantly, leave the clothes drier thus reducing drying time and energy consumption, and reduce wear and tear on clothes.

\section{Upgrade Description:}

When replacing your clothes washer, choose an ENERGY STAR-labeled model. ENERGY STAR clothes washers can reduce energy consumption by up to $70 \%$ and are available in top-loading and front-loading designs Some ENERGY STAR models use up to $50 \%$ less water in addition to saving energy. 
Note: Our calculations bill savings, typical upgrade costs, and cost-effectiveness are for a model with the lowest efficiency that qualifies for the ENERGY STAR label.

\section{Purchasing Tips:}

- Choose a clothes washer with high-speed spin cycles. This feature removes more water from clothes, which reduces the energy and time required for drying.

- Select a low water-use, high efficiency washer. Front-loading tumble-action washers can cut energy use by up to 70 percent, reduce water consumption significantly, and may actually get clothes cleaner. 1

- Look for pre-soaking and/or "suds saver" options which conserve energy.

- Clothes washers come with EnergyGuide yellow and black labels. Use these labels to select the most efficient model for the capacity you have chosen.

\section{More Information:}

- ENERGY STAR clothes washer product list

- General Information from DOE

- Top-Rated Energy-Efficient Clothes Washers from ACEEE

Return to upgrades list

\section{When replacing your main refrigerator, choose an ENERGY STAR-labeled model}

\section{Economic Benefits:}

Estimate Yearly Bill Savings:

Estimated Lifetime Energy Savings:

Estimated Added Cost

Maximum Price for 10 Year

Payback:

Return on Investment:

Upgrade Pays for Itself in:

11 years

\section{Additional Benefits:}

Energy-efficient refrigerators are quieter, run less often, release less heat into your kitchen, and keep their contents cool longer during power outages.

\section{Upgrade Description:}

When replacing your main refrigerator, choose an ENERGY STAR®-labeled model. ENERGY STAR refrigerators must exceed federal efficiency standards by at least $15 \%$. Models that are up to $40 \%$ more efficient than the federal standards are available.

Note: Our calculations bill savings, typical upgrade costs, and cost-effectiveness are for a model with the lowest efficiency that qualifies for the ENERGY STAR label.

\section{Purchasing Tips:}

- Be especially careful in choosing a refrigerator because it will use more energy than any other kitchen appliance.

- Refrigerators with the freezer on the bottom or the top are the most efficient. Bottom-mounted freezer models use about $16 \%$ less energy than side-by-side models. Top-mounted freezer models use about $13 \%$ less energy than a side-by side. 1

- Through-the-door icemakers and water dispensers are convenient and reduce the need to open the door, which helps maintain a more constant temperature. However, these convenient items will increase your refrigerator's energy use by 14 to $20 \%$. 1

- Too large a refrigerator wastes space and energy. One that is too small can mean extra trips to the grocery store. Decide which size fits your needs, then compare the EnergyGuide yellow and black label on each so you can purchase the most energy efficient make and model. The most efficient refrigerator size is $16-20$ cubic feet. $\frac{1,2}{2}$

\section{More Information:}

- ENERGY STAR refrigerator product list

- Consortium for Energy Efficiency refrigerator product list

- Top-Rated Refrigerators from ACEEE

- Energy Saving Tips for refrigerators from "Energy Savers" 


\section{Additional Benefits:}

Ceiling fans mix the air in your home more effectively, creating more even temperatures and a more comfortable home.During the cooling season, ceiling fans create air movement that makes you feel cooler, which in turn allows you to raise your air conditioner thermostat setting, reducing your cooling bill.Energy efficient ceiling fans add less heat to the inside of your home during the cooling season.

\section{Upgrade Description:}

When buying a new ceiling fan, choose an ENERGY STAR-labeled model.An ENERGY STAR-labeled fan/light combination unit can save about $50 \%$ of the energy use of a typical-efficiency unit.

\section{Purchasing Tips:}

- If your ceiling fan includes lights, most of your energy savings will come from buying a ceiling fan with an ENERGY STAR-qualified light kit.

- It's important to buy the right size fan for your space and install it properly. The ENERGY STAR link below provides more details.

\section{More Information:}

- ENERGY STAR qualifying ceiling fan product list

\section{When replacing your gas water heater, choose an energy efficient model}

\section{Economic Benefits:}

Estimate Yearly Bill Savings:

Estimated Lifetime Energy

Savings:

\section{Estimated Added Cost:}

Maximum Price for 10 Year

Payback:

Return on Investment:

Upgrade Pays for Itself in:

\section{Additional Benefits:}

Efficient gas-fired water heaters may hold their temperature longer following power interruptions and operate more safely.

\section{Upgrade Description:}

When replacing your gas water heater, choose an energy-efficient model with an Energy Factor of 0.62 or higher.

Note: Our calculations bill savings, typical upgrade costs, and cost-effectiveness assume the efficient water heater has an energy factor of 0.62 and recovery efficiency of 0.76 . Higher efficiency units are available, and would provide additional energy savings.

\section{Purchasing Tips:}

- The most important measure of efficiency for water heaters is the Energy Factor EF. The higher the EF, the more efficient the water heater.

- Purchase a water heater whose tank is internally insulated with at least R-16. $\underline{5}$

- A water heater that is too large for your home not only has a higher purchase cost but will increase your energy costs due to excessive cycling and standby losses. The resources below provide good, simple guidance on proper sizing of water heaters. The size, or "capacity", of a fuel-fired water heater should be judged by its first hour rating FHR, not its tank size. Due to larger burners, some gas water heaters with smaller tanks actually have higher capacities FHRs than models with larger tanks.

- Many types of water heaters are now available, such as "demand" tankless, "indirect" or "integrated", and solar-assisted water heaters. More Information

- New and/or efficient gas water heaters may have different venting and flue requirements. When replacing your water heater make sure your contractor assesses your existing flue, follows new code requirements for venting water heaters, and obtains necessary permits and inspections. $\underline{3}$

\section{More Information:}


- GAMA consumer's directory click on "Consumers"

- How to prevent health and safety problems with combustion equipment

\section{When replacing your well pump, choose an energy efficient model}

\section{Economic Benefits:}

Estimate Yearly Bill Savings:

Estimated Lifetime Energy Savings:

Estimated Added Cost:

Maximum Price for 10 Year Payback:

Return on Investment:

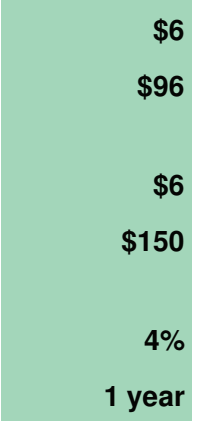

Upgrade Pays for Itself in:

1 year

\section{Additional Benefits:}

None available.

\section{Upgrade Description:}

When buying a new water well pump, choose an energy efficient model.These units can save up to one-third of the energy use of a typical well pump.

Note: Our calculations bill savings, typical upgrade costs, and cost-effectiveness are for a well pump and motor with a combined $60 \%$ efficiency.

\section{Purchasing Tips:}

- Well pump/motor efficiency measures how much of the electrical energy is converted to useful work to move water. The efficiency is usually not a published value, but it can be calculated based on the manufacturer's published performance data.Ask your pump dealer for help, or use the links below for guidance.

- The most energy efficient well pumps are those designed to be powered by solar power systems.

- One of the best ways to reduce well-pump energy use is to reduce water use, particularly outdoor use. To reduce water use,install low-flow plumbing fittings, low-flush toilets, and water-efficient irrigation equipment e.g., timers or drip irrigation.

\section{More Information:}

- Irrigation pumping systems

- Irrigation water pumps North Dakota Extension Service

- Home Energy Magazine

[Return to upgrades list]

\section{When replacing your dishwasher, choose an ENERGY STAR-labeled model}

Economic Benefits:

Estimate Yearly Bill Savings:

Estimated Lifetime Energy

Savings:

Estimated Added Cost:

Maximum Price for 10 Year

Payback:

Return on Investment:

Upgrade Pays for Itself in:

\section{Additional Benefits:}

Some ENERGY STAR dishwashers reduce water use and/or have shorter run times.

\section{Upgrade Description:}

When replacing your dishwasher, choose an ENERGY STAR- labeled model. ENERGY STAR dishwashers must be at least $15 \%$ more efficient than federal efficiency standards. Models are available that are over twice as efficient as a standard new dishwasher. Many

ENERGY STAR models reduce water consumption in addition to saving energy. Note: Our calculations bill savings, typical upgrade costs, and cost-effectiveness are for a model with the lowest efficiency that qualifies for the ENERGY STAR label. 
- Choose a dishwasher that allows you the option of air drying rather than heat drying. Air drying uses much less energy than heat drying. 1

- Look for models with internal "booster heaters" which permit lower water heater temperature settings.

- Choose a dishwasher that provides several wash cycle options, such as "energy-saving" or "short wash" cycles. These features reduce energy and water consumption.

- Select a dishwasher with the appropriate capacity for your needs. Dishwashers are classified as either compact or standard capacity. Compact models use less energy but also hold fewer dishes. If you have to run the compact dishwasher more often, you could actually use more energy than with a standard capacity dishwasher. 1

- Dishwashers come with EnergyGuide yellow and black labels. Use these labels to select the most efficient model for the capacity you have chosen.

\section{More Information:}

- ENERGY STAR dishwasher product list

- Top-Rated Energy-Efficient Dishwashers from ACEEE

- Tips for Lowering Your Dishwasher Energy Usage from DOE

[Return to upgrades list

\section{HOME ENERGY SAVER}

\section{ROADMAP TO RESULTS}

Ease into the process of making your home more efficient. If you're new to this, or you're on a very tight budget, start with the lowest-hanging fruit like double-checking your water heater's temperature setting.

The next easy steps are simple things that will fit into your shopping basket: maybe a few compact fluorescent lamps or a roll of weatherstripping.

When it's time to replace that old fridge, or other appliances, take time to shop smart. At a minimum, look for the ENERGY STAR rating. There are detailed lists of products that will take you even farther. Remember: you're not simply spending money, you're investing for profit and comfort.

Redoing your kitchen? New roof? Finally adding that in-law unit? Creating successful projects can take some work. Take the time to find a home performance specialist to help you think thru all the options ahead of time, and then find the right contractor with the skills to do the job right.

Not only will these upgrades pay for themselves many times over, there are all kinds of financial incentives to help you trim the cost. And many of the "non-energy benefits" will be worth more than money can buy.

And, don't forget about saving water (which also saves energy).

Stumped? Ask an expert. 


\section{DISCLAIMER}

The Home Energy Saver website and related content were prepared as an account of or to expedite work sponsored at least in part by the United States Government. While we strive to provide correct information, neither the United States Government nor any agency thereof, nor The Regents of the University of California, nor any of their employees, makes any warranty, express or implied, or assumes any legal responsibility for the accuracy, completeness, or usefulness of any information, apparatus, product, or process disclosed, or represents that its use would not infringe privately owned rights. Reference herein to any specific commercial product, process, or service by its trade name, trademark, manufacturer, or otherwise, does not necessarily constitute or imply its endorsement, recommendation, or favoring by the United States Government or any agency thereof, or The Regents of the University of California. Use of the Laboratory or University's name for endorsements is prohibited. The views and opinions of authors expressed herein do not necessarily state or reflect those of the United States Government or any agency thereof or The Regents of the University of California. Neither Berkeley Lab nor its employees are agents of the US Government.

Berkeley Lab web pages link to many other websites. Such links do not constitute an endorsement of the content or company and we are not responsible for the content of such links.

\section{Information That You Voluntarily Provide}

We do not collect personal information unless you choose to provide it to us. If you provide us with personal information, for example your address, we use that information to provide better information to you through the Home Energy Saver, as well as to further our research. While we strive to protect your personal information, our Laboratory conducts open fundamental research and cannot guarantee or warrant that your information will never be compromised or disclosed.

\section{How Information is Used}

The information you provide on this site is used to provide the service to you, to improve the service, and to conduct and support research by Berkeley Lab researchers and their collaborators.

\section{Information Protection}

For site security purposes and to ensure that this service remains available to all users, this University of California computer system employs software programs to monitor network traffic to identify unauthorized attempts to upload or change information, or otherwise cause damage. If such monitoring reveals evidence of possible abuse or criminal activity, such evidence may be provided to appropriate law enforcement officials. We may also share this information with other affiliated institutions in order to help secure other systems and networks. Unauthorized attempts to upload or change information on this server are strictly prohibited and may be punishable under California and Federal law.

\section{Sharing of Information}

We may share the information you choose to provide to us with our research collaborators and our partners who help to provide this service. We may share the information you provide to us with the Department of Energy and other Federal Agencies. Information you share with us may also be covered by California and Federal laws that provide for mandatory disclosure under certain circumstances, such as subpoenas and records requests.

A full description of the privacy policy and disclaimers can be found at the following web site 
Appendix D2 - Home Energy Saver Report - Original Upgrades Configuration

\section{HOME ENERGY SAVER}

REPORT

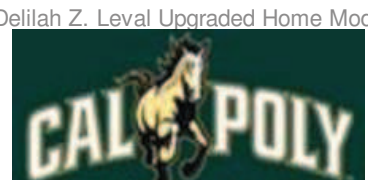

MUSTANGS

This report is generated by the Home Energy Saver

web-based energy audit tool, developed by

the U.S. Department of Energy's

Lawrence Berkeley National Laboratory,

and can be reached at http://hes.Ibl.gov 


\section{HOUSE CONFIGURATION}

\section{General Information}

Name or other identifier this home/session : upgraded house; User's email address : delilahzoe@gmail.com; Purpose of this assessment : Hypothetical analysis; Address : 1276 Karen Road; Other text if other is checked : ; City : San Pablo; State : California; City with most similar climate to modeled house : Oakland; Year house was built : 1953; People living in the house, by age - 0 to 5 years : 0 ; People living in the house, by the age - 6-13: 1; People living in the house, by the age - 14-64 : 2; People living in the house, by the age - 65 plus : 0; Check for actual electricity prices in your area. : no; Utilities List : ; Select your tariff from the list below. :

\section{Energy Prices}

Energy Prices - Electricity : 0.144; Energy Prices - Piped Natural Gas : 1.270; Energy Prices - Liquid Propane Gas (LPG) : 2.770; Energy Prices - Fuel Oil : 2.940;

\section{Exterior Shading}

Extension of roof eaves or patios - Front : 1.00; Extension of roof eaves or patios - Right : 1.00; Extension of roof eaves or patios - Back : 1.00; Extension of roof eaves or patios - Left : 1.00; Height of large shade trees - Front : 0 ; Height of large shade trees - Right : 0; Height of large shade trees - Back : 0 ; Height of large shade trees - Left : 0; Height of neighboring houses stories - Front : One; Height of neighboring houses stories - Right : One; Height of neighboring houses stories - Back : One; Height of neighboring houses stories - Left : One;

\section{Air Tightness}

Does the house have weatherstripping : Yes; Enter the measured or estimated air leakage rate : 0.00;

\section{Foundation Floor}

Foundation type : Slab-on-grade Foundation; Foundation insulation level : None; Insulation level of the floor above the basement or crawlspace : R-0 (no insulation);

\section{Walls}

Darkness of exterior wall surfaces (left wall slider) : 0.70; Do all the walls have similar construction? : Yes; Darkness of exterior wall surfaces (right wall slider) : 0.70 Darkness of exterior wall surfaces (back wall slider) : 0.70; Darkness of exterior wall surfaces (slider) : 0.70; Wood Siding : ; Wood Siding : ; Wood Siding : ; Wood Siding : ; Stucco : ; Wood Siding : ; Stucco : ; Stucco : ; Stucco : ; Vinyl Siding : ; Stucco : ; Vinyl Siding : ; Vinyl Siding : ; Vinyl Siding : ; Aluminum Siding : ; Vinyl Siding : ; Aluminum Siding : ; Aluminum Siding : ; Aluminum Siding : ; Brick Veneer : ; Aluminum Siding : ; Brick Veneer : ; Brick Veneer : ; Brick Veneer : ; Wood Siding : ; Wood Siding : ; Brick Veneer : ; Wood Siding : ; Wood Siding: ; Stucco : ; Stucco : ; Wood Siding : ; Stucco : ; Stucco : ; Vinyl Siding : ; Vinyl Siding : ; Stucco : ; Vinyl Siding : ; Vinyl Siding : ; Aluminum Siding : ; Aluminum Siding :; Vinyl Siding : ; Aluminum Siding : ; Aluminum Siding : ; Brick Veneer : ; Brick Veneer :; Aluminum Siding : ; Brick Veneer : ; Brick Veneer : ; Wood Siding : ; Wood Siding : ; Brick Veneer : ; Wood Siding : ; Wood Siding : ; Stucco : ; Stucco : ; Wood Siding : ; Stucco : ; Stucco : ; Vinyl Siding : ; Vinyl Siding : ; Stucco : ; Vinyl Siding : ; Vinyl Siding : ; Aluminum Siding : ; Aluminum Siding : ; Vinyl Siding : ; Aluminum Siding : ; Aluminum Siding : ; Brick Veneer : ; Brick Veneer : ; Aluminum Siding :; Brick Veneer :; Brick Veneer : ; Wood Siding : ; Wood Siding : ; Brick Veneer : ; Wood Siding : ; Wood Siding :; Stucco : ; Stucco : ; Wood Siding : ; Stucco : ; Stucco : ; Vinyl Siding : ; Vinyl Siding : ; Stucco : ; Vinyl Siding : ; Vinyl Siding : ; Aluminum Siding : ; Aluminum Siding :; Vinyl Siding ; Aluminum Siding : ; Aluminum Siding : ; Brick Veneer : ; Brick Veneer : ; Aluminum Siding : ; Brick Veneer : ; Brick Veneer : ; Wood Siding : ; Wood Siding : ; Brick Veneer : ; Wood Siding : ; Wood Siding : ; Stucco : ; Stucco : ; Wood Siding : ; Stucco : ; Stucco : ; Vinyl Siding : ; Vinyl Siding : ; Stucco : ; Vinyl Siding : ; Vinyl Siding :; Aluminum Siding : ; Aluminum Siding : ; Vinyl Siding : ; Aluminum Siding : ; Aluminum Siding : ; Brick Veneer : ; Brick Veneer : ; Aluminum Siding : ; Brick Veneer : ; Brick Veneer : ; Wood Siding : ; Wood Siding : ; Brick Veneer : ; Wood Siding : ; Wood Siding : ; Stucco : ; Stucco : ; Wood Siding : ; Stucco : ; Stucco : ; Vinyl Siding : ; Vinyl Siding: : Stucco : ; Vinyl Siding : ; Vinyl Siding : ; Aluminum Siding : ; Aluminum Siding : ; Vinyl Siding : ; Aluminum Siding : ; Aluminum Siding : ; Brick Veneer : ; Brick Veneer: ; Aluminum Siding : ; Brick Veneer : ; Brick Veneer : ; Wood Siding : ; Wood Siding : ; Brick Veneer : ; Wood Siding : ; Wood Siding : ; Stucco : ; Stucco : ; Wood Siding : ; Stucco : ; Stucco : ; Vinyl Siding : ; Vinyl Siding : ; Stucco : ; Vinyl Siding : ; Vinyl Siding : ; Aluminum Siding : ; Aluminum Siding : ; Vinyl Siding : ; Aluminum Siding: ; Aluminum Siding : ; Brick Veneer : ; Brick Veneer : ; Aluminum Siding : ; Brick Veneer : ; Brick Veneer : ; Wood Siding : ; Wood Siding : ; Brick Veneer : ; Wood Siding : ; Wood Siding : ; Stucco : ; Stucco :; Wood Siding : ; Stucco : ; Stucco : ; Vinyl Siding : ; Vinyl Siding : ; Stucco : ; Vinyl Siding : ; Vinyl Siding : ; Aluminum Siding : ; Aluminum Siding : ; Vinyl Siding: ; Aluminum Siding :; Aluminum Siding :; Brick Veneer : ; Brick Veneer : ; Aluminum Siding : ; Brick Veneer : ; Brick Veneer :; Wood Siding : ; Wood Siding : ; Brick Veneer : ; Wood Siding : ; Wood Siding : ; Stucco : ; Stucco : ; Wood Siding : ; Stucco : ; Stucco : ; Vinyl Siding : ; Vinyl Siding : ; Stucco : ; Vinyl Siding : ; Vinyl Siding: ; Aluminum Siding :; Aluminum Siding : ; Vinyl Siding : ; Aluminum Siding : ; Aluminum Siding : ; Brick Veneer : ; Brick Veneer : ; Aluminum Siding : ; Brick Veneer : ; Brick Veneer :; Wood Siding : ; Wood Siding :; Brick Veneer :; Wood Siding :; Wood Siding :; Stucco : ; Stucco :; Wood Siding :; Stucco : ; Stucco : ; Vinyl Siding : ; Vinyl Siding : ; Stucco : ; Vinyl Siding : ; Vinyl Siding : ; Aluminum Siding : ; Aluminum Siding : ; Vinyl Siding : ; Aluminum Siding : ; Aluminum Siding : ; Brick Veneer : ; Brick Veneer : ; Aluminum Siding : ; Brick Veneer :; Brick Veneer : ; Wood Siding : ; Wood Siding : ; Brick Veneer : ; Wood Siding : ; Wood Siding : ; Stucco : ; Stucco : ; Wood Siding : ; Stucco : ; Stucco : ; Vinyl Siding : ; Vinyl Siding : ; Stucco : ; Vinyl Siding : ; Vinyl Siding : ; Aluminum Siding : ; Aluminum Siding : ; Vinyl Siding : ; Aluminum Siding : ; Aluminum Siding : ; Brick Veneer : ; Brick Veneer : ; Aluminum Siding : ; Brick Veneer : ; Brick Veneer : ; Wood Siding: ; Wood Siding : ; Brick Veneer : ; Wood Siding : ; Wood Siding : ; Stucco : ; Stucco : ; Wood Siding : ; Stucco : ; Stucco : ; Vinyl Siding : ; Vinyl Siding : ; Stucco : Vinyl Siding : ; Vinyl Siding : ; Aluminum Siding :; Aluminum Siding :; Vinyl Siding : ; Aluminum Siding :; Aluminum Siding : ; Brick Veneer :; Brick Veneer : ; Aluminum Siding : ; Brick Veneer : ; Brick Veneer : ; Wood Siding : ; Wood Siding : ; Brick Veneer : ; Wood Siding : ; Wood Siding : ; Stucco : ; Stucco : ; Wood Siding : ; Stucco : Stucco : ; Vinyl Siding : ; Vinyl Siding: ; Stucco : ; Vinyl Siding : ; Vinyl Siding : ; Aluminum Siding : ; Aluminum Siding : ; Vinyl Siding : ; Aluminum Siding : ; Aluminum Siding : ; Brick Veneer : ; Brick Veneer : ; Aluminum Siding : ; Brick Veneer : ; Brick Veneer : ; Wood Siding : ; Wood Siding : ; Brick Veneer : ; Wood Siding : ; Wood Siding : ; Stucco : ; Stucco : ; Wood Siding : ; Stucco : ; Stucco : ; Vinyl Siding : ; Vinyl Siding : ; Stucco : ; Vinyl Siding : ; Vinyl Siding : ; Aluminum Siding : ; Aluminum Siding : ; Vinyl Siding : ; Aluminum Siding: ; Aluminum Siding : ; Brick Veneer : ; Brick Veneer : ; Aluminum Siding : ; Brick Veneer : ; Brick Veneer : ; Wood Siding : ; Wood Siding : ; Brick Veneer : ; Wood Siding : ; Wood Siding : ; Stucco : ; Stucco : ; Wood Siding : ; Stucco : ; Stucco : ; Vinyl Siding : ; Vinyl Siding : ; Stucco : ; Vinyl Siding : ; Vinyl Siding : ; Aluminum Siding: ; Aluminum Siding : ; Vinyl Siding : ; Aluminum Siding : ; Aluminum Siding : ; Brick Veneer : ; Brick Veneer : ; Aluminum Siding ; Brick Veneer : ; Brick Veneer : ; Wood Siding : ; Wood Siding : ; Brick Veneer : ; Wood Siding : ; Wood Siding : ; Stucco : ; Stucco : ; Wood Siding : ; Stucco : ; Stucco ; Vinyl Siding : ; Vinyl Siding : ; Stucco : ; Vinyl Siding : ; Vinyl Siding : ; Aluminum Siding : ; Aluminum Siding : ; Vinyl Siding : ; Aluminum Siding : ; Aluminum Siding : Brick Veneer : ; Brick Veneer : ; Aluminum Siding : ; Brick Veneer : ; Brick Veneer : ; Wood Siding : ; Wood Siding : ; Brick Veneer : ; Wood Siding : ; Wood Siding : ; Stucco : ; Stucco : ; Wood Siding : ; Stucco : ; Stucco : ; Vinyl Siding : ; Vinyl Siding : ; Vinyl Siding : ; Stucco : ; Vinyl Siding : ; Aluminum Siding : ; Aluminum Siding : ; Aluminum Siding : ; Vinyl Siding:; Aluminum Siding: ; Brick Veneer : ; Brick Veneer : ; Brick Veneer :; Aluminum Siding : ; Brick Veneer : ; Wood Siding: ; Wood Siding ; Wood Siding : ; Brick Veneer : ; Wood Siding : ; Stucco : ; Stucco : ; Stucco : ; Wood Siding : ; Stucco : ; Vinyl Siding : ; Vinyl Siding : ; Vinyl Siding : ; Stucco : ; Vinyl Siding : ; Aluminum Siding: ; Aluminum Siding : ; Aluminum Siding : ; Vinyl Siding : ; Aluminum Siding : ; Brick Veneer :; Brick Veneer : ; Brick Veneer : ; Aluminum Siding : ; Brick Veneer : ; Wood Siding : ; Wood Siding : ; Wood Siding : ; Brick Veneer : ; Wood Siding : ; Stucco : ; Stucco : ; Stucco : ; Wood Siding : ; Stucco : ; Vinyl Siding : ; Vinyl Siding : ; Vinyl Siding : ; Stucco : ; Vinyl Siding : ; Aluminum Siding : ; Aluminum Siding : ; Aluminum Siding : ; Vinyl Siding : ; Aluminum Siding : ; Brick Veneer : ; Brick Veneer : ; Brick Veneer : ; Aluminum Siding : ; Brick Veneer : ; Wood Siding : ; Wood Siding : ; Wood Siding : ; Brick Veneer : ; Wood Siding : ; Stucco : ; Stucco : ; Stucco : ; Wood Siding : ; Stucco : ; Vinyl Siding : ; Vinyl Siding : ; Vinyl Siding : ; Stucco : ; Vinyl Siding : ; Aluminum Siding : ; Aluminum Siding : ; Aluminum Siding : ; Vinyl Siding : ; Aluminum Siding : ; Brick Veneer : ; Brick Veneer : ; Brick Veneer : ; Aluminum Siding : ; Brick Veneer : ; Wood Siding : ; Wood Siding : ; Wood Siding : ; Brick Veneer : ; Wood Siding :; Stucco : ; Stucco : ; Stucco : ; Wood Sipling: ; Stucco : ; Vinyl Siding : ; Vinyl Siding : ; Vinyl Siding : ; Stucco : ; Vinyl Siding : ; Aluminum Siding : ; Aluminum Siding : ; Aluminum Siding : ; Vinyl Siding : ; Aluminum Siding : ; Brick Veneer : ; Brick Veneer : ; Brick Veneer :; Aluminum Siding : ; Brick 
Veneer: ; Wood Siding : ; Wood Siding : ; Wood Siding : ; Brick Veneer : ; Wood Siding : ; Stucco : ; Stucco : ;

Siding : ; Vinyl Siding : ; Stucco : ; Vinyl Siding : ; Aluminum Siding : ; Aluminum Siding : ; Aluminum Siding :; 作 Brick Veneer:; Wood Siding : ; Stucco :; Stucco : ; Stucco : ; Wood Siding : ; Stucco : ; Vinyl Siding : ; Vinyl Siding : ; Vinyl Siding : ; Stucco : ; Vinyl Siding : ; Aluminum Siding : ; Aluminum Siding : ; Aluminum Siding : ; Vinyl Siding : ; Aluminum Siding : ; Brick Veneer : ; Brick Veneer : ; Brick Veneer : ; Aluminum Siding : ; Brick Veneer : ; Wood Siding : ; Wood Siding : ; Wood Siding :; Brick Veneer : ; Wood Siding : ; Stucco : ; Stucco : ; Stucco : ; Wood Siding : ; Stucco : ; Vinyl Siding : ; Vinyl Siding : ; Vinyl Siding : ; Stucco : ; Vinyl Siding : ; Aluminum Siding :; Aluminum Siding : ; Aluminum Siding : ; Vinyl Siding : ; Aluminum Siding : ; Brick Veneer : ; Brick Veneer: ; Brick Veneer : ; Aluminum Siding:; Brick Veneer : ; Wood Siding : ; Wood Siding : ; Wood Siding : ; Brick Veneer : ; Wood Siding : ; Stucco : ; Stucco :; Stucco : ; Wood Siding : ; Stucco : ; Vinyl Siding : ; Vinyl Siding : ; Vinyl Siding : ; Stucco : ; Vinyl Siding : ; Aluminum Siding : ; Aluminum Siding : ; Aluminum Siding :; Vinyl Siding : ; Aluminum Siding : ; Brick Veneer : ; Brick Veneer : ; Brick Veneer : ; Aluminum Siding : ; Brick Veneer : ; Wood Siding : ; Wood Siding : ; Wood Siding : ; Brick Veneer:; Wood Siding : ; Stucco : ; Stucco : ; Stucco : ; Wood Siding : ; Stucco : ; Vinyl Siding : ; Vinyl Siding : ; Vinyl Siding : ; Stucco : ; Vinyl Siding :; Aluminum Siding : ; Aluminum Siding : ; Aluminum Siding : ; Vinyl Siding : ; Aluminum Siding : ; Brick Veneer : ; Brick Veneer : ; Brick Veneer : ; Aluminum Siding : ; Brick Veneer:; Wood Siding:; Wood Siding : ; Wood Siding :; Brick Veneer : ; Wood Siding : ; Stucco : ; Stucco : ; Stucco : ; Wood Siding : ; Stucco : ; Vinyl Siding : ; Vinyl Siding : ; Vinyl Siding : ; Stucco : ; Vinyl Siding : ; Aluminum Siding : ; Aluminum Siding :; Aluminum Siding :; Vinyl Siding : ; Aluminum Siding : ; Brick Veneer :; Brick Veneer : ; Brick Veneer : ; Aluminum Siding : ; Brick Veneer : ; Wood Siding : ; Wood Siding : ; Wood Siding : ; Brick Veneer : ; Wood Siding : ; Stucco : ; Stucco : ; Stucco : ; Wood Siding : ; Stucco : ; Vinyl Siding : ; Vinyl Siding : ; Vinyl Siding : ; Stucco : ; Vinyl Siding : ; Aluminum Siding : ; Aluminum Siding : ; Aluminum Siding : Vinyl Siding:; Aluminum Siding : ; Brick Veneer : ; Brick Veneer : ; Brick Veneer : ; Aluminum Siding : ; Brick Veneer : ; Wood Siding : ; Wood Siding : ; Wood Siding : ; Brick Veneer : ; Wood Siding : ; Stucco : ; Stucco : ; Stucco : ; Wood Siding : ; Stucco : ; Vinyl Siding : ; Vinyl Siding : ; Vinyl Siding : ; Stucco : ; Vinyl Siding : ; Aluminum Siding : ; Aluminum Siding : ; Aluminum Siding : ; Vinyl Siding : ; Aluminum Siding : ; Brick Veneer : ; Brick Veneer : ; Brick Veneer : ; Aluminum Siding : ; Brick Veneer : ; Wood Siding: ; Wood Siding : ; Wood Siding :; Brick Veneer : ; Wood Siding : ; Stucco : ; Stucco : ; Stucco : ; Wood Siding : ; Stucco : ; Vinyl Siding : ; Vinyl Siding : ; Vinyl Siding : ; Stucco : ; Vinyl Siding : ; Aluminum Siding:; Aluminum Siding : ; Aluminum Siding : ; Vinyl Siding : ; Aluminum Siding : ; Brick Veneer : ; Brick Veneer : ; Brick Veneer : ; Aluminum Siding : ; Brick Veneer : ; Wood Siding : ; Wood Siding : ; Wood Siding : ; Brick Veneer : ; Wood Siding : ; Stucco :; Stucco : ; Stucco : ; Wood Siding : ; Stucco : ; Vinyl Siding : ; Vinyl Siding : ; Vinyl Siding : ; Stucco : ; Vinyl Siding : ; Aluminum Siding : ; Aluminum Siding : ; Aluminum Siding : ; Vinyl Siding : ; Aluminum Siding : ; Brick Veneer : ; Brick Veneer : ; Brick Veneer : ; Brick Veneer : ; Aluminum Siding : ; Wood Siding : ; Wood Siding : ; Wood Siding :; Wood Siding : ; Brick Veneer : ; Stucco : ; Stucco : ; Stucco : ; Stucco : ; Wood Siding : ; Vinyl Siding : ; Vinyl Siding : ; Vinyl Siding : ; Vinyl Siding : ; Stucco : ; Aluminum Siding : ; Aluminum Siding : ; Aluminum Siding : ; Aluminum Siding : ; Vinyl Siding : ; Brick Veneer : ; Brick Veneer : ; Brick Veneer : ; Brick Veneer :; Aluminum Siding : ; R-0 (no insulation) : ; R-0 (no insulation) : ; R-0 (no insulation) : ; R-0 (no insulation) : ; Brick Veneer : ; R-5 (1 inch) : ; R-5 (1 inch) : ; R-5 (1 inch) : ; R-5 (1 inch) : ; R-0 (no insulation) : ; R-10 (2 inches) : ; R-10 (2 inches) : ; R-10 (2 inches) : ; R-10 (2 inches) : ; R-5 (1 inch) : ; Stucco : ; Stucco : ; Stucco : ; Stucco : ; R-10 (2 inches) : ; Brick : ; Brick : ; Brick : ; Brick : ; Stucco : ; None : ; None : ; None : ; None : ; Brick : ; Stucco : ; Stucco : ; Stucco : ; Stucco : ; None : ; Brick : ; Brick : ; Brick :; Brick : ; Stucco : ; None : ; None : ; None : ; None : ; Brick : ; Stucco : ; Stucco : ; Stucco : ; Stucco : ; None : ; Brick : ; Brick : ; Brick : ; Brick : ; Stucco : ; None : ; None : ; None : ; None : ; Brick : ; R-0 (no insulation) : ; R-0 (no insulation) : ; R-0 (no insulation) : ; R-0 (no insulation) : ; None : ; R-0 (no insulation) : ;

\section{Doors Windows}

Doors - Front of house - Number of doors each wall : 1 door; Doors - Front of house - Door Type : Uninsulated wood/wood/wood; Doors - Front of house - Door U-Factor 0.00; Doors - Right side of house - Number of doors each wall : 0 doors; Doors - Right side of house - Door Type : Uninsulated wood/wood/wood; Doors - Right side of house - Door U-Factor : 0.00; Doors - Back of house - Number of doors each wall : 1 door; Doors - Back of house - Door Type : Uninsulated wood/wood/wood; Doors Back of house - Door U-Factor : 0.00; Doors - Left side of house - Number of doors each wall : 1 door; Right : Interior Drapes; Doors - Left side of house - Door Type : Custom door (enter U-Factor below); Back : Interior Drapes; Doors - Left side of house - Door U-Factor : 1.30; Left : Interior Drapes; Windows - Does the house have diff types of windows on each side : No; Single-pane, clear" 15 heat_cool_input windowTypeFront Detailed Doors-Windows windowTypeFront sp-tinted-a radio 0 scna stna "Single-pane, tinted" 16 heat_cool input windowTypeFront Detailed Doors-Windows windowTypeFront dp-clear-a radio 0 scna : No; Single-pane, tinted : No; Double-pane, clear: No; Double-pane, tinted : No; Double-pane, solar-control low-E : No; Double-pane, clear : No; Double-pane, tinted : No; Single-pane, clear : No; Double-pane, solarcontrol low-E : No; Custom window : No; Single-pane, tinted : No; Double-pane, insulating low-E, argon gas fill : No; Custom window : No; Double-pane, clear : No; Singlepane, clear : No; Custom window : No; Double-pane, tinted : No; Single-pane, tinted : No; Custom window : No; Double-pane, solar-control low-E : No; Double-pane, clear : No; Double-pane, clear : No; Double-pane, tinted : No; Double-pane, tinted : No; Double-pane, solar-control low-E : No; Double-pane, solar-control low-E : No; Double-pane, solar-control low-E, argon gas fill : ; Double-pane, insulating low-E, argon gas fill : ; Double-pane, insulating low-E : ; Single-pane, clear : ; Double-pane, insulating low-E, argon gas fill : ; Single-pane, tinted : ; Triple-pane, insulating low-E, argon gas fill : ; Double-pane, clear : ; U-Factor (0.00:5.00) : 0.30; Double-pane, tinted : 0.30; Solar heat gain coefficient (0.00:1.00) : 0.30; Double-pane, solar-control low-E : 0.30; Window Area Front : 48.02; Double-pane, solar-control low-E, argon gas fill : ; Window Area Right : 20.97; Double-pane, insulating low-E : 20.97; Window Area Back : 30.17; Double-pane, insulating low-E, argon gas fill : 30.17 ; Window Area Left : 57.68 ; Triple-pane, insulating low-E, argon gas fill : 57.68; Movable Insulation Front : 0.00; U-Factor (0.00:5.00) : 0.00; Movable Insulation Right : 0.00; Solar heat gain coefficient (0.00:1.00) 0.00; Movable Insulation Back : 0.00; Single-pane, clear : 0.00; Movable Insulation Left : 0.00; Single-pane, tinted : 0.00; Movable Shades Front : Interior Drapes; Doublepane, clear : Interior Drapes; Movable Shades Right : Interior Drapes; Double-pane, tinted : Interior Drapes; Movable Shades Back : Interior Drapes; Double-pane, solar-control low-E : Interior Drapes; Movable Shades Left : Interior Drapes; Double-pane, clear : Interior Drapes; Double-pane, tinted : Interior Drapes; Double-pane, solar-control low-E : Interior Drapes; Double-pane, insulating low-E, argon gas fill : Interior Drapes; Single-pane, clear : Interior Drapes; Single-pane, tinted : Interior Drapes; Double-pane, clear : Interior Drapes; Double-pane, tinted : Interior Drapes; Double-pane, solar-control low-E : Interior Drapes; Double-pane, solar-control low-E, argon gas fill : ; Double-pane, insulating low-E : ; Double-pane, insulating low-E, argon gas fill : ; Triple-pane, insulating low-E, argon gas fill : ; U-Factor (0.00:5.00) : 0.00; Solar heat gain coefficient (0.00:1.00): 0.00; Single-pane, clear : 0.00; Single-pane, tinted : 0.00; Double-pane, clear : 0.00; Double-pane, tinted : 0.00; Double-pane, solarcontrol low-E : 0.00; Double-pane, clear : 0.00; Double-pane, tinted : 0.00; Double-pane, solar-control low-E : 0.00; Double-pane, insulating low-E, argon gas fill : 0.00 ; Single-pane, clear : 0.00; Single-pane, tinted : 0.00; Double-pane, clear : 0.00; Double-pane, tinted : 0.00; Double-pane, solar-control low-E : 0.00; Double-pane, solar-control low-E, argon gas fill : ; Double-pane, insulating low-E : ; Double-pane, insulating low-E, argon gas fill : ; Triple-pane, insulating low-E, argon gas fill : ; U-Factor (0.00:5.00) : $\mathbf{0 . 0 0}$; Solar heat gain coefficient $(0.00: 1.00): 0.00$;

\section{Attic Roof}

Attic or ceiling type : Unconditioned Attic; Insulation level of the attic floor : R-0 (no insulation); R-0 (no insulation) : ; R-11 (3-5 inches) : ; R-13 (5-6 inches) : ; R-15 (6-7 inches) : ; R-19 (7-9 inches) : ; R-21 (9-10 inches) : ; R-0 (no insulation) : ; R-11 (3-5 inches) : ; R-13 (5-6 inches) : ; R-15 (6-7 inches) : ; R-19 (7-9 inches) : ; R-21 (9-10 inches) : ; R-27 (10-13 inches) : ; R-0 (no insulation) : ; R-11 (3-5 inches) : ; R-13 (5-6 inches) : ; R-15 (6-7 inches) : ; R-19 (7-9 inches) : ; R-21 (9-10 inches) : ; R-27 (10-13 inches) : ; R-0 (no insulation) : ; R-11 (3-5 inches) : ; R-13 (5-6 inches) : ; R-15 (6-7 inches) : ; R-19 (7-9 inches) : ; R-21 (9-10 inches) : ; R-27 (10-13 inches) : ; R-0 (no insulation) : ; R-11 (3-5 inches) : ; R-13 (5-6 inches) : ; R-15 (6-7 inches) : ; R-19 (7-9 inches) : ; R-21 (9-10 inches) : ; R-27 (10-13 inches) : ; R-0 (no insulation) : ; R-0 (no insulation) : ; R-0 (no insulation) : ; R-0 (no insulation) : ; R-0 (no insulation) : ; R-0 (no insulation) : ; R-11 (3-5 inches) : ; R-13 (5-6 inches) : ; R-15 (6-7 inches) : ; R-0 (no insulation) : ; R-11 (3-5 inches) : ; R-13 (5-6 inches) : ; R-15 (6-7 inches) : ; R-19 (7-9 inches) : ; R-21 (9-10 inches) : ; R-0 (no insulation) : ; R-11 (3-5 inches) : ; R-13 (5-6 inches) : ; R-15 (6-7 inches) : ; R-19 (7-9 inches) : ; R-21 (9-10 inches) : ; R-0 (no insulation) : ; R-11 (3-5 inches) : ; R-13 (5-6 inches) : ; R-15 (6-7 inches) : ; R-19 (7-9 inches) : ; R-21 (9-10 inches) : ; R-0 (no insulation) : ; R-11 (3-5 inches) : ; R-13 (5-6 inches) : ; R-15 (6-7 inches) : ; R-19 (7-9 inches) : ; R-21 (9-10 inches) : ; Slider : 0.800; User-entered exterior roof absorptance : 0.800; Slope (or pitch) of roof : 3:12 (14 degrees);

\section{Ducts Pipes}

Duct location : Unknown/not applicable; Are the ducts insulated? : No/Don't Know; Are the ducts sealed? : No/Don't Know; Are the boiler pipes insulated? : No/Don't Know; Does the boiler also provide the hot tap water? : No - I have a separate boiler and water heater. ;

\section{Thermostat}

Settings changed during the day and evening : No Change; Standard or Programmable Thermostat : standard; Temperature setting - Heating temperature : 64; Temperature setting - Cooling temperature : 81; Weekdays Heating Day Degrees : 64; Weekdays Heating Day Time : 8; Weekdays Heating Night Degrees : 68; Weekdays Heating Night Time : 17; Weekdays Cooling Day Degrees : 81; Weekdays Cooling,DayTime : 8; Weekdays Cooling Night Degrees : 78; Weekdays Cooling Night Time : 17; Weekend/Holiday Heating Day Degrees : 64; Weekend/Holiday Heating Day Time 1 1 5 / 
17; Weekend/Holiday Cooling Day Degrees : 81; Weekend/Holiday Cooling Day Time : 8; Weekend/Holiday Cooling Night Degrees : 78; Weekend/Holiday Cooling Night Time : 17; Temperature setting - Heating temperature : 8; Temperature setting - Cooling temperature : 8; Weekdays Heating Wake degrees : 68; Weekdays Heating Wake Time : 7; Weekdays Heating Away degrees : 64; Weekdays Heating Away Time : 9; Weekdays Heating Evening degrees : 68; Weekdays Heating Evening Time : 19; Weekdays Heating Sleep degrees : 64; Weekdays Heating Sleep Time : 23; Weekdays Cooling Wake degrees : 78; Weekdays Cooling Wake Time : 7; Weekdays Cooling Away degrees : 81; Weekdays Cooling Away Time : 9; Weekdays Cooling Evening degrees : 78; Weekdays Cooling Evening Time : 19; Weekdays Cooling Sleep degrees 81; Weekdays Cooling Sleep Time : 23; Weekend/Holiday Heating Wake degrees : 68; Weekend/Holiday Heating Wake Time : 8; Weekend/Holiday Heating Away degrees 64; Weekend/Holiday Heating Away Time : 11; Weekend/Holiday Heating Evening degrees : 68; Weekend/Holiday Heating Evening Time : 19; Weekend/Holiday Heating Sleep degrees : 64; Weekend/Holiday Heating Sleep Time : 23; Weekend/Holiday Cooling Wake degrees : 78; Weekend/Holiday Cooling Wake Time : 8; Weekend/Holiday Cooling Away degrees : 81; Weekend/Holiday Cooling Away Time : 11; Weekend/Holiday Cooling Evening degrees : 78; Weekend/Holiday Cooling Evening Time : 19; Weekend/Holiday Cooling Sleep degrees : 81; Weekend/Holiday Cooling Sleep Time : 23;

\section{Heating Equipment}

Type of heating system : Room (through-the-wall) gas furnace; Heating system capacity : 60000; Heating system efficiency : $50.00 ;$ Year heating system installed : 1970; Percentage of the house's floor area heated by a central or room heating system : 19; Percentage of the house's heating needs supplied by a wood burning stove or portable heater : 37 ;

\section{Cooling Equipment}

Type of cooling system : No Cooling Equipment; Cooling system capacity : 0; Cooling system efficiency : 0.00; Year cooling system installed : 1970; Percentage of the house's floor area cooled by the cooling system : 100; Hours room air conditioner is on during an average day in the cooling season : None; Number of months room air conditioner is on during an average cooling season ? : None; Does the house have ceiling fans? : Yes; Number of ceiling fans : 2; Does the house have a whole-house fan? : No; Hours per day the whole-house fan is used : 0 ; Months per year the whole-house fan is used : 0; Does the house have portable fans? : Yes; Number of portable fans

\section{Water Heating}

Water heater fuel : Piped Natural Gas; Year purchased : 1972; Does occupant pay for water heater fuel? : Yes; Is an adult at home on weekdays? : Yes; Energy Factor : 0.47; Recovery Efficiency : 0.76; Rated Input : 38000.00; Storage tank capacity (gallons) : 40; Temperature Setting : Medium-Low; Water heater location : Garage;

\section{Lighting}

Kitchen : 2; Kitchen Bulb Type : Halogen Tochiere; Kitchen Number of bulbs in fixture : 1^1;2^1; Kitchen Sum of wattages for all bulbs in fixture : $\mathbf{1}^{\wedge} 60 ; 2 \wedge 60 ;$ Kitchen Usage (Hrs/day) : 1; Dining Room : 0; Dining Room Bulb Type : ; Dining RoomNumber of bulbs in fixture : ; Dining RoomSum of wattages for all bulbs in fixture : ; Dining RoomUsage (Hrs/day) : ; Living Room : 3; Living Room Bulb Type : Halogen Tochiere; Living Room Number of bulbs in fixture : 1^1;2^1;3^1; Living Room Sum of wattages for all bulbs in fixture : $1^{\wedge} 60 ; 2^{\wedge} 60 ; 3^{\wedge} 60$; Living Room Usage (Hrs/day) : 1; Family Room : 0; Family Room Bulb Type : ; Family Room Number of bulbs in fixture : ; Family Room Sum of wattages for all bulbs in fixture : ; Family Room Usage (Hrs/day) : ; Master Bedroom : 3; Master Bedroom Bulb Type : Halogen Tochiere; Master Bedroom Number of bulbs in fixture : $\mathbf{1}^{\wedge} 1 ; 2^{\wedge} 1 ; 3^{\wedge} 1$; Master BedroomSum of wattages for all bulbs in fixture : $1^{\wedge} 65 ; 2^{\wedge} 65 ; 3^{\wedge} 65 ;$ Master Bedroom Usage (Hrs/day) : 1; Hall : 0; Hall Bulb Type : ; Hall Number of bulbs in fixture : ; Hall Sum of wattages for all bulbs in fixture : ; Hall Usage (Hrs/day) :; All Bedrooms : 1; All Bedrooms Bulb Type : Halogen Tochiere; All Bedrooms Number of bulbs in fixture : 1^1; All Bedrooms Sum of wattages for all bulbs in fixture : 1^60; All Bedrooms Usage (Hrs/day) : 1; All Bathrooms : 4; All Bathrooms Bulb Type : Halogen Tochiere; All Bathrooms Number of bulbs in fixture : $1^{\wedge} 1 ; 2^{\wedge} 1 ; 3^{\wedge} 1 ; 4^{\wedge} 1$; All Bathrooms Sum of wattages for all bulbs in fixture : $1^{\wedge} 60 ; 2^{\wedge} 60 ; 3^{\wedge} 14 ; 4^{\wedge} 14$; All Bathrooms Usage (Hrs/day) : 1; All Closets : 0; All Closets Bulb Type : ; All Closets Number of bulbs in fixture : ; All Closets Sum of wattages for all bulbs in fixture : ; All Closets Usage (Hrs/day) : ; Utility Room : 1; Utility Room Bulb Type : ; Utility Room Number of bulbs in fixture : ; Utility Room Sum of wattages for all bulbs in fixture : ; Utility Room Usage (Hrs/day) : ; Garage : 0; Garage Bulb Type : ; Garage Number of bulbs in fixture : ; Garage Sum of wattages for all bulbs in fixture : ; Garage Usage (Hrs/day) : ; Outdoor Lighting : 5; Outdoor Lighting Bulb Type : Halogen Tochiere; Outdoor Lighting Number of bulbs in fixture : $1^{\wedge} 1 ; 2^{\wedge} 1 ; 3^{\wedge} 1 ; 4^{\wedge} 1 ; 5^{\wedge} 1$; Outdoor Lighting Sum of wattages for all bulbs in fixture : $1^{\wedge} 120 ; 2^{\wedge} 120 ; 3^{\wedge} 120 ; 4^{\wedge} 120 ; 5^{\wedge} 120 ;$ Outdoor Lighting Usage (Hrs/day) : 1 ; Other : 0 ; Other Bulb Type : ; Other Number of bulbs in fixture : ; Other Sum of wattages for all bulbs in fixture : ; Other Usage (Hrs/day) : ;

\section{Refrigerators Freezers}

Year made : ; Size : Large (19-21 cu ft); Type : Large (19-21 cu ft); Energy Star : Yes; Year made : present; Size : present; Type : present; Energy Star : No; Year made present; Size : present; Type : present; Energy Star : No; Year made : present; Size : present; Type : present; Year made : present; Size : present; Type : present;

\section{Cooking Dishwashing}

Stove fuel : Natural Gas or Propane; hours per day stove used : 1 hour; Pilot Light : No; Oven fuel : Electricity; Hours per week oven used : 2 hours; Pilot Light : No; Does house have/use a dishwasher : Yes; Energy Start Qualified: Yes; Loads washed per week : 4;

\section{Laundry}

Does house have/use a clothes washer? : Yes; ENERGY STAR Qualified : Yes; Hot/Warm : 2; Hot/Cold : 0; Warm/Warm : 3; Warm/Cold : 2; Cold/Cold : 0; Dryer fuel : Electricity; Number of loads dried per week : 7;

\section{HotTubs Spas Pumps}

How many hours/day does the pool pump run? : House doesn't have a pool pump; How many months of the year does the pool pump run? : 0 ; Is there a pool heater? No; How is the spa heated? : House doesn't have a spa/hot tub; If spa is heated only when it is being used, how many hours per week is it used?" 6 major appliance input sumpPumpSize Detailed HotTubs-Spas-Pumps sumpPumpSize sump-pump-size 0 values:1-4 What is the size of the sump pump? 7 major_appliance_input : $\mathbf{0}$; What is the size of the sump pump? : House doesn't have a sump/sewage pump; How many hours/year does the sump operate? : 5 hours/year; Indicate the vertical distance that water is lifted. : House doesn't have a well pump; Combined pump and motor efficiency : Typical - 40\%; Is house water pressure provided by gravity or pump? : Pump; How much water is used outdoors? : Roughly 5 min/day with garden hose;

\section{Entertainment}

Number of Units : 1; Average Per-unit Use : 2; Unit of Time : Hours; Unit of Calendar : Day; Energy Star? : No; Number of Units : 0; Average Per-unit Use : 2; Unit of Time Hours; Unit of Calendar : Day; Number of Units : 0; Average Per-unit Use : 2; Unit of Time : Hours; Unit of Calendar : Day; Number of Units : 0; Average Per-unit Use : 2 ; Unit of Time : 2; Unit of Calendar : Day; Number of Units : 0; Average Per-unit Use : 2; Unit of Time : Hours; Unit of Calendar : Day; Number of Units : 1; Average Per-unit Use : 4; Unit of Time : Hours; Unit of Calendar: Week; Energy Star? : No; Number of Units : 1; Average Per-unit Use : 2; Unit of Time : Hours; Unit of Calendar : Week; Energy Star? : No; Number of Units : 1; Average Per-unit Use : 1; Unit of Time : Minutes; Unit of Calendar : Day; Number of Units : 0; Average Per-unit Use : 0; Unit of Time : Minutes; Unit of Calendar : Day; Number of Units : 1; Average Per-unit Use : 1; Unit of Time : Hours; Unit of Calendar : Day; Number of Units : 1; Average Per-unit Use : 2; Unit of Time : Hours; Unit of Calendar : Week; Number of Units : 1; Average Per-unit Use : 30; Unit of Time : Minutes; Unit of Calendar : Week; Number of Units : 1; Average Per-unit Use : 30; Unit of Time : Minutes; Unit of Calendar : Week; Energy Star : No; Number of Units : 1; Average Per-unit Use : 2; Unit of Time : Hours; Unit of Calendar: Week;

\section{Home Office}

Number of Units : 1; Average Per-unit Use : 5; Unit of Time : Hours; Unit of Calendar : Day; Number of Units : 1; Average Per-unit Use : 5; Unit of Time : Hours; Unit of Calendar : Day: Number of Units : 0; Average Per-unit Use : 0; Unit of Time : Minutes; Unit of Calendar : Day; Number of Units : 0; Average Per-unit Use : 1; Unit of Time : Hours; Unit of Calendar: Week; Number of Units : 1; Average Per-unit Use : 1; Unit of Time : Hours; Unit of Calendar : Week; Number of Units : 1; Average Per-unit Use : 5; Unit of Time : Hours; Unit of Calendar: Day; Number of Units : 0; Average Per-unit Use : 4; Unit of Time : Minutes; Unit of Calendar : Day; Energy Star : No; Number of Units : 0; Average Per-unit Use : 4; Unit of Time : Minutes; Unit of Calendar : Dayy 146mer of Units : 0; Average Per-unit Use : 30 ; Unit of Time : Minutes; Unit of Calendar Day; Average Per-unit Use : 0; Unit of Time : Hours; Unit of Calendar : Day 


\section{Miscellaneous Kitchen Equipment}

Bottled Water (With heating or chilling ability) : Day; Energy Star Qualified : No; Instant Hot Water : No; Number of Units : 0; Average Per-unit Use : 1; Unit of Time : Hours; Unit of Calendar : Week; Number of Units : 1; Average Per-unit Use : 30; Unit of Time : Minutes; Unit of Calendar : Day; Average Per-unit Use : 1; Unit of Time : Hours; Unit of Calendar : Day; Number of Units : 0; Average Per-unit Use : 30; Unit of Time : Minutes; Unit of Calendar : Day; Average Per-unit Use : 1; Unit of Time : Hours; Unit of Calendar : Day; Number of Units : 0; Average Per-unit Use : 0; Unit of Time : Minutes; Unit of Calendar : Week; Number of Units : 0; Average Per-unit Use : 0; Unit of Time : Hours; Unit of Calendar : Month; Number of Units : 0; Average Per-unit Use : 1; Unit of Time : Hours; Unit of Calendar : Week; Number of Units : 1; Average Per-unit Use : 1; Unit of Time : Minutes; Unit of Calendar : Day; Number of Units : 0; Average Per-unit Use : 0; Unit of Time : Hours; Unit of Calendar : Week; Number of Units : 1; Average Per-unit Use : 6; Unit of Time : Minutes; Unit of Calendar : Day; Number of Units : 0; Average Per-unit Use : 4; Unit of Time : Minutes; Unit of Calendar : Day; Average Per-unit Use : Day; Unit of Time : Minutes; Unit of Calendar : Day;

\section{Other Appliances}

Number of Units : 0; Number of Units : 0; Average Per-unit Use : 1; Unit of Time : Hours; Unit of Calendar : Week; Number of Units : 1; Average Per-unit Use : 1; Unit of Time : Hours; Unit of Calendar : Week; Number of Units : 0; Average Per-unit Use : 24; Unit of Time : Hours; Unit of Calendar : Day; Number of Units : 0; Average Per-unit Use : 1; Unit of Time : Hours; Unit of Calendar : Day; Months in the year : 4; Number of Units : 2; Number of Units : 0; Average Per-unit Use : 24; Unit of Time : Hours; Unit of Calendar : Day; Energy Star : No; Number of Units : 1; Number of Units : 1; Average Per-unit Use : 5; Unit of Time : Hours; Unit of Calendar : Day; Months in year : 4; Number of Units : 0; Average Per-unit Use : 1; Unit of Time : Hours; Unit of Calendar : Day; Months in year : 4; Number of Units : 0; Average Per-unit Use : 24; Unit of Time : Hours; Unit of Calendar : Day; Energy Star : No; Number of Units : 0; Average Per-unit Use : 8; Unit of Time : Minutes; Unit of Calendar : Day; Number of Units : 1; Average Per-unit Use : 7; Unit of Time : Minutes; Unit of Calendar : Day; Number of Units : 0; Average Per-unit Use : 1; Unit of Time : Hours; Unit of Calendar : Day; Months in year : 4; Number of Units : 0; Average Per-unit Use : 24; Unit of Time : Hours; Unit of Calendar : Day; Number of Units : 1; Average Per-unit Use : 20; Unit of Time : Minutes; Unit of Calendar : Week; Number of Units : 0; Average Per-unit Use : 2; Unit of Time : Hours; Unit of Calendar : Day; Months in year : 4; Number of Units : 0; Number of Units : 0; Average Per-unit Use : 1; Unit of Time : Hours; Unit of Calendar : Day; Months in year : 4; Number of Units : 0; Average Per-unit Use : 6; Unit of Time : Hours; Unit of Calendar : Week; Number of Units : 0; Name : ; Average Per-unit Use : 0; Unit of Time : Minutes; Unit of Calendar : Day; Watts : ; Number of Units : 0; Name : ; Average Per-unit Use : 0; Unit of Time : Minutes; Unit of Calendar : Day; Watts : ; Number of Units : 0; Name : ; Average Per-unit Use : 0; Unit of Time : Minutes: Unit of Calendar : Day; Watts : ; Number of Units : 0; Name : ; Average Per-unit Use : 0; Unit of Time : Minutes; Unit of Calendar : Day; Watts : ; Number of Units : 0; Name : ; Average Per-unit Use : 0; Unit of Time : Minutes; Unit of Calendar : Day; Watts : ;

\section{House Shape Size}

Conditioned floor area (all stories combined) ?: 1113; Direction faced by front of house : North; Stories above ground level : 1; Interior floor-to-ceiling height : 8 feet; Rectangle : ; L-Shape : ; Front S-Shape : ; Back S-Shape : ; T-Shape : ; U-Shape : ; Split- or Tri- Level : ; Townhouse : ; Front door is on Top Side : ; Front door is on Right Side : ; Front door is on Bottom Side : ; Front door is on Left Side : ; Length of the house (from front to back) $\mid r$ : 25.84; Width of the house (from left to right) $\mid r$ : 43.07; Front door is on Top Side : ; Front door is on Right Side : ; Front door is on Bottom Side : ; Front door is on Left Side : ; Side 1 Dimension : 10.00; Side 2 Dimension : 10.00; Side 3 Dimension : 43.07; Side 4 Dimension : 25.84; Front door is on Top Side : ; Front door is on Right Side : ; Front door is on Bottom Side : ; Front door is on Left Side : ; Side 1 Dimension : 10.00; Side 2 Dimension : 10.00; Side 3 Dimension : 10.00; Side 4 Dimension : 10.00; Side 3 Dimension : 43.07 ; Side 4 Dimension : 25.84 ; Front door is on Top Side : ; Front door is on Right Side : ; Front door is on Bottom Side : ; Front door is on Left Side : ; Side 1 Dimension : 10.00; Side 2 Dimension : 10.00; Side 3 Dimension : 10.00; Side 4 Dimension : 10.00; Side 3 Dimension : 43.07; Side 4 Dimension : 25.84; Front door is on Top Side : ; Front door is on Right Side : ; Front door is on Bottom Side : ; Front door is on Left Side : ; Side 1 Dimension : 43.07; Side 2 Dimension : 10.00; Side 3 Dimension : 10.00; Side 4 Dimension : 10.00; Side 3 Dimension : 25.84; Side 4 Dimension : 10.00; Front door is on Top Side : ; Front door is on Right Side : ; Front door is on Bottom Side : ; Front door is on Left Side : ; Side 1 Dimension : 10.00; Side 2 Dimension : 10.00; Side 3 Dimension : 10.00; Side 4 Dimension : 43.07; Side 3 Dimension : 25.84; Side 4 Dimension : 10.00; Front door is on Top Side : ; Front door is on Right Side : ; Front door is on Bottom Side : ; Front door is on Left Side : ; Side 1 Dimension : 10.00; Side 2 Dimension : 10.00; Side 3 Dimension : 43.07; Side 4 Dimension : 25.84; Front door is on Top Side : ; Front door is on Right Side : ; Front door is on Bottom Side : ; Front door is on Left Side : ; Front door is on Right Side : ; Front door is on Bottom Side : ; Front door is on Left Side : ; Length of the house (from front to back) اr : 25.84; Width of the house (from left to right) $\backslash \mathrm{r}:$ : 43.07;

\section{Skylights}

Single-pane, clear : : Single-pane, tinted : : Double-pane, clear : ; Double-pane, tinted : ; Double-pane, solar-control low-E : ; Double-pane, clear : ; Double-pane, tinted : ; Double-pane, solar-control low-E : ; Double-pane, insulating low-E, argon gas fill : ; Single-pane, clear : ; Double-pane, clear : ; Double-pane, tinted : ; Double-pane, solarcontrol low-E : ; Double-pane, solar-control low-E, argon gas fill : ; Double-pane, insulating low-E : ; Double-pane, insulating low-E, argon gas fill : ; Triple-pane, insulating low-E, argon gas fill : ; Skylight U-Factor : $\mathbf{0 . 0 0}$; Skylight Solar heat gain coefficient : $\mathbf{0 . 0 0}$; Enter the R-value of movable skylight insulation : $\mathbf{0 . 0 0}$; Select the type of movable interior skylight shades : None; Skylight size : 0.00 ; 


\section{YEARLY ENERGY COSTS}

Providing more details will make your results more accurate.

$\begin{array}{lr}\text { Existing Home } & \$ 1,255 \\ \text { With Upgrades } & \$ 903\end{array}$

903

\begin{tabular}{|c|c|c|c|c|c|c|c|}
\hline & Total & Heating & Cooling & Hot Water & $\begin{array}{c}\text { Large } \\
\text { Appliances }\end{array}$ & $\begin{array}{c}\text { Small } \\
\text { Appliances }\end{array}$ & Lighting \\
\hline Existing Home & $\$ 1,255$ & $\$ 117$ & $\$ 11$ & $\$ 268$ & $\$ 532$ & $\$ 229$ & $\$ 98$ \\
\hline $\begin{array}{l}\text { With } \\
\text { Upgrades }\end{array}$ & $\$ 903$ & $\$ 117$ & $\$ 11$ & $\$ 79$ & $\$ 369$ & $\$ 229$ & $\$ 98$ \\
\hline Savings & $\$ 352$ & $\$ 0$ & $\$ 0$ & $\$ 189$ & $\$ 163$ & $\$ 0$ & $\$ 0$ \\
\hline
\end{tabular}

Important Note: These are initial estimates only, and results may vary. If the owner has not already done so, we strongly recommend that they retain a professional energy auditor to develop a detailed work scope and budget for improving the home. We also recommend the Home Performance with ENERGY STAR program when considering home improvements. 
YEARLY WHOLE HOUSE RESULTS

\begin{tabular}{|c|c|c|c|c|c|}
\hline & & Existing Home & With Upgrades & Savings & $\begin{array}{l}\text { Percentage } \\
\text { Reductions }\end{array}$ \\
\hline \multirow{4}{*}{ Whole House } & Energy Bill & $\$ 1,255$ & $\$ 903$ & $\$ 352$ & $28 \%$ \\
\hline & Electricity & $5111 \mathrm{kWh}$ & 3552 kWh & 1559 kWh & $30.5 \%$ \\
\hline & Natural Gas & 409 Therms & 305 Therms & 104 Therms & $25.4 \%$ \\
\hline & Emissions & $7328 \mathrm{CO} 2$ & $5333 \mathrm{CO} 2$ & $1995 \mathrm{lb} . \mathrm{CO}_{2}$ & $27.2 \%$ \\
\hline \multirow{3}{*}{ Heating } & Energy Bill & $\$ 117$ & $\$ 117$ & $\$ 0$ & $0 \%$ \\
\hline & Natural Gas & 92 Therms & 92 Therms & 0 Therms & $0 \%$ \\
\hline & Emissions & $1075 \mathrm{lb} . \mathrm{CO}_{2}$ & $1075 \mathrm{lb} . \mathrm{CO}_{2}$ & $0 \mathrm{lb} . \mathrm{CO}_{2}$ & $0 \%$ \\
\hline \multirow{3}{*}{ Cooling } & Energy Bill & $\$ 11$ & $\$ 11$ & $\$ 0$ & $0 \%$ \\
\hline & Electricity & $75 \mathrm{kWh}$ & $75 \mathrm{kWh}$ & $0 \mathrm{kWh}$ & $0 \%$ \\
\hline & Emissions & $37 \mathrm{lb} . \mathrm{CO}_{2}$ & $37 \mathrm{lb} . \mathrm{CO}_{2}$ & $\mathrm{O} \mathrm{lb} . \mathrm{CO}_{2}$ & $0 \%$ \\
\hline \multirow{3}{*}{ Hot Water } & Energy Bill & $\$ 268$ & $\$ 79$ & $\$ 189$ & $70.5 \%$ \\
\hline & Natural Gas & 211 Therms & 62 Therms & 149 Therms & $70.6 \%$ \\
\hline & Emissions & $2465 \mathrm{lb} . \mathrm{CO}_{2}$ & $724 \mathrm{lb} . \mathrm{CO}_{2}$ & $1741 \mathrm{lb} . \mathrm{CO}_{2}$ & $70.6 \%$ \\
\hline \multirow{4}{*}{ Large Appliances } & Energy Bill & $\$ 532$ & $\$ 369$ & $\$ 163$ & $30.6 \%$ \\
\hline & Electricity & $2763 \mathrm{kWh}$ & 1204 kWh & $1559 \mathrm{kWh}$ & $56.4 \%$ \\
\hline & Natural Gas & 106 Therms & 151 Therms & -45 Therms & $-42.5 \%$ \\
\hline & Emissions & $2617 \mathrm{lb} . \mathrm{CO}_{2}$ & $2362 \mathrm{lb} . \mathrm{CO}_{2}$ & $255 \mathrm{lb} . \mathrm{CO}_{2}$ & $9.7 \%$ \\
\hline \multirow{3}{*}{ Small Appliances } & Energy Bill & $\$ 229$ & $\$ 229$ & $\$ 0$ & $0 \%$ \\
\hline & Electricity & $1590 \mathrm{kWh}$ & 1590 kWh & $0 \mathrm{kWh}$ & $0 \%$ \\
\hline & Emissions & $793 \mathrm{lb} . \mathrm{CO}_{2}$ & 793 lb. $\mathrm{CO}_{2}$ & $0 \mathrm{lb} . \mathrm{CO}_{2}$ & $0 \%$ \\
\hline \multirow{3}{*}{ Lighting } & Energy Bill & $\$ 98$ & $\$ 98$ & $\$ 0$ & $0 \%$ \\
\hline & Electricity & $683 \mathrm{kWh}$ & 683 kWh & $0 \mathrm{kWh}$ & $0 \%$ \\
\hline & Emissions & $341 \mathrm{lb} . \mathrm{CO}_{2}$ & $341 \mathrm{lb} . \mathrm{CO}_{2}$ & $0 \mathrm{lb} . \mathrm{CO}_{2}$ & $0 \%$ \\
\hline
\end{tabular}

Heating electricity values include fan or pumping energy for homes that have forced-air or water-based heating systems powered by circulation pumps. The values for Hot Water include taps and faucets only; the energy consumed by the water heater to supply hot water for appliances such as clothes washers and dishwashers is included instead in the rows for those appliances. 
YEARLY HEATING AND COOLING RESULTS

Show Details

Total Cost

\begin{tabular}{lr} 
Cost & $\$ 128$ \\
Heating & $\$ 117$ \\
Cooling & $\$ 11$ \\
& \\
\hline Energy Use & Total Energy \\
Heating & 92 therms75 kWh \\
Cooling & 92 therms \\
\hline
\end{tabular}

Notes: this house is $37 \%$ heated by wood fuel.

$19 \%$ of the floor area is heated and $100 \%$ cooled.

Heating electricity values include fan or pumping energy for homes that have forced-air or water-based heating systems powered by circulation pumps.

What if my results don't match my energy bill?

\section{$\because$ HOME ENERGY SAVER}

YEARLY LARGE APPLIANCES AND WATER HEATING RESULTS

Show Details

\begin{tabular}{l|r} 
Appliance & $\begin{array}{r}\text { Total } \\
\text { Cost }\end{array}$ \\
\hline First Refrigerator & $\$ 124$ \\
Stove & $\$ 42$ \\
Oven & $\$ 34$ \\
Clotheswasher & $\$ 134$ \\
Clothesdryer & $\$ 210$ \\
\hline Dishwasher & $\$ 56$ \\
Hot Water: Taps and & $\$ 268$ \\
Faucets & \\
Totals & $\$ 800$
\end{tabular}

Equipment energy is the energy used by motors, heating elements, and burners inside your appliances. This number excludes the energy consumed by your water heater to supply hot water for appliances such as clothes washers and dishwashers (which is included instead in the rows for those appliances).

What if my results don't match my energy bill? 
YEARLY SMALL APPLIANCES RESULTS

Show Details $?$

$\begin{array}{lrr}\text { Category } & \text { Energy Use } & \text { Energy Costs } \\ \text { Entertainment } & 345 \mathrm{kWh} & \mathbf{\$ 5 0} \\ \text { HomeOffice } & 361 \mathrm{kWh} & \mathbf{\$ 5 2} \\ \text { Kitchen } & 470 \mathrm{kWh} & \mathbf{\$ 6 8} \\ \text { Other } & 382 \mathrm{kWh} & \mathbf{\$ 5 5}\end{array}$

What if my results don't match my energy bill?

\section{H. HOME ENERGY SAVER}

YEARLY LIGHTING RESULTS

Here is the calculated Yearly lighting bill based on the inputs you provided:

Show Details 2

$\begin{array}{lrr}\text { Room } & \text { Energy Use } & \text { Energy Costs } \\ \text { All Bathrooms } & 108 \mathrm{kwh} & \mathbf{\$ 1 6} \\ \text { All Bedrooms } & 22 \mathrm{kwh} & \mathbf{\$ 3} \\ \text { Kitchen } & 132 \mathrm{kwh} & \mathbf{\$ 1 9} \\ \text { Living Room } & 132 \mathrm{kwh} & \mathbf{\$ 1 9} \\ \text { Master Bedroom } & 72 \mathrm{kwh} & \mathbf{\$ 1 0} \\ \text { Outdoor Lighting } & 143 \mathrm{kwh} & \mathbf{\$ 2 1} \\ \text { Utility Room } & 74 \mathrm{kwh} & \mathbf{\$ 1 1}\end{array}$

What if my results don't match my energy bill? 
UPGRADE RECOMMENDATIONS SUMMARY

Visit 'Recommendations' to see more information on each upgrade.

\begin{tabular}{|c|c|c|c|c|c|}
\hline $\begin{array}{l}\text { Yearly } \\
\text { Savings }\end{array}$ & $\begin{array}{c}\text { Estimated } \\
\text { Added Cost }\end{array}$ & $\frac{\text { How Much is }}{\text { Too Much? }}$ & $\frac{\text { Simple }}{\text { Payback }}$ & $\frac{\text { Estimated }}{\text { ROI }}$ & $\frac{\text { Emissions }}{\left(\text { lbs. } \mathrm{CO}_{2}\right)}$ \\
\hline$\$ 316$ & $\$ 510$ & $\$ 3160$ & & $59 \%$ & 1995 \\
\hline
\end{tabular}

Important Note: These are initial estimates only, and results may vary. If the owner has not already done so, we strongly recommend that they retain a professional energy auditor to develop a detailed work scope and budget for improving the home. We also recommend the Home Performance with ENERGY STAR program when considering home improvements.

Upgrades Requiring Investment
1. Indoor lights
2. Electric clothes dryer
3. Clothes washer
4. Gas water heater

Other benefits that often come along with these energy-saving upgrades

- Fluorescent lamps last several times longer than ordinary incandescent bulbs, which saves you the time and expense of replacing bulbs when they burn out.

- Natural gas clothes dryers reduce your home's peak load on the power grid compared to an electric dryer.

- ENERGY STAR® clothes washers can reduce water use significantly, leave the clothes drier thus reducing drying time and energy consumption, and reduce wear and tear on clothes.

- Efficient gas-fired water heaters may hold their temperature longer following power interruptions and operate more safely. 


\section{UPGRADE RECOMMENDATIONS ?}

What efficiency level would you like to model for the initial selection of upgrades?

EnergyStar $\quad *$

What simple payback period would you like to use for selecting 10 * upgrades?

Rows that are dimmed are not included in the calculated values for the retrofit package.

To include them check their boxes and recalculate.

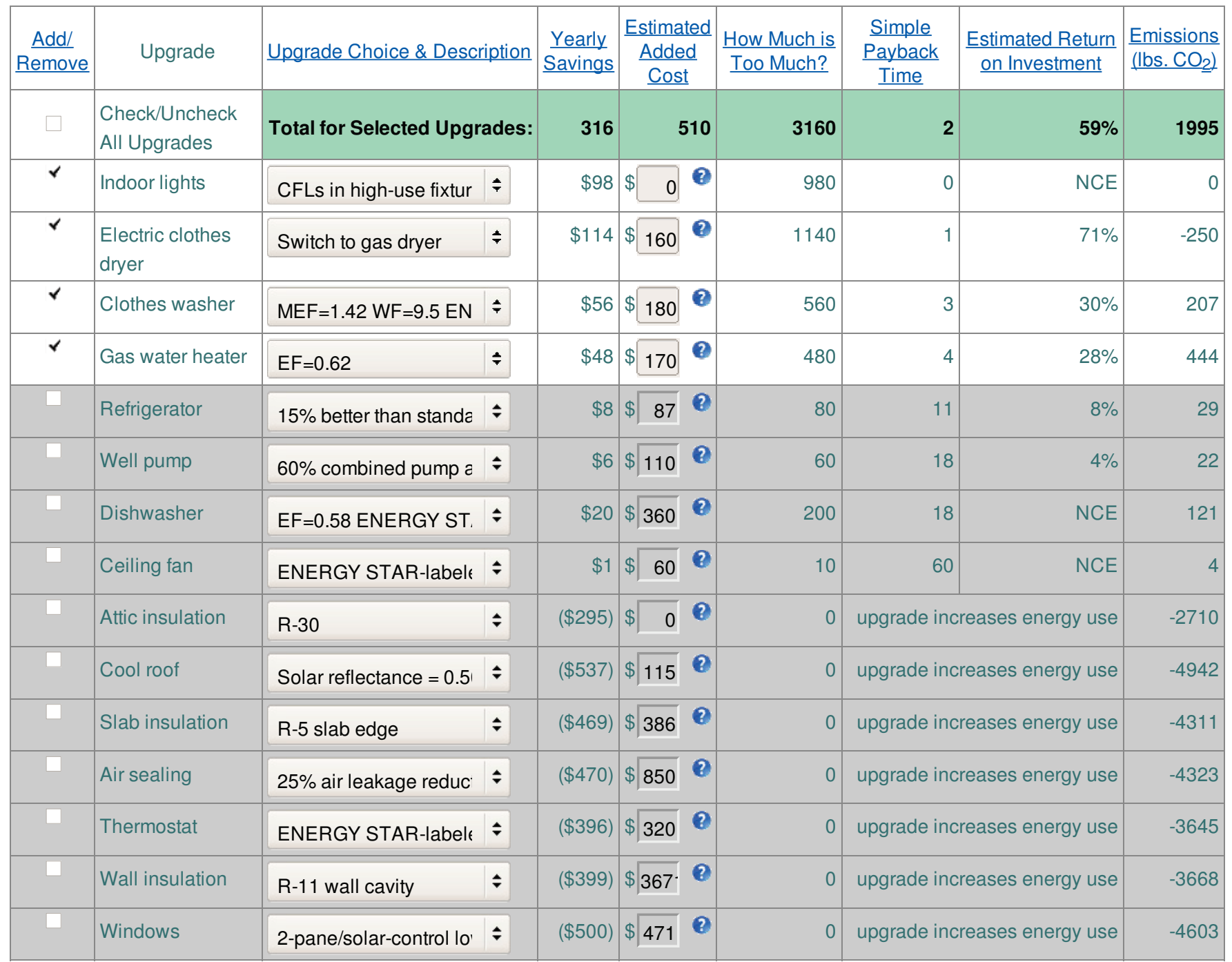

Important Note: These are initial estimates only, and results may vary. If the owner has not already done so, we strongly recommend that they retain a professional energy auditor to develop a detailed work scope and budget for improving the home. We also recommend the Home Performance with ENERGY STAR program when considering home improvements.

NCE $=$ Not Cost Effective. This upgrade will not pay for itself in your situation. There may be other reasons, such as improved comfort, to implement the upgrade, or it could be made more cost-effective if the investment cost is reduced.

Note: Each of the upgrades in the table above are evaluated in isolation from the others. If the efficiency level is changed for one upgrade, its potential impact on other upgrades will not be counted in the row-by-row estimates. However, these kinds of interactions are included in the "package" totals associated with the whole-house totals and chart at the top of the page, for the upgrades selected as part of the package. For example, if the furnace efficiencies are raised, the energy savings from wall insulation will not change in the row estimate, but the incremental savings from including insulation in the package will be less due to the more efficient furnace's impact on reducing the energy required to make up heat losses through the wall (there is less energy being used, so less to save). 


\section{DETAILED UPGRADE RECOMMENDATIONS REPORT}

This is a printable report of the upgrades selected for the home. These upgrades have the potential to save $\$ 352$ each year on the utility bill.

Upgrade Package Summary: Estimate Yearly Bill Savings:

Estimated Lifetime Energy Savings:

Estimated Added Cost:

Maximum Price for 10 Year Payback:

Return on Investment:

Upgrade Pays for Itself in:

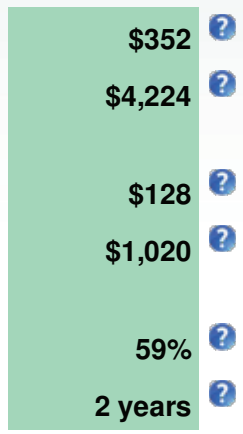

\section{You selected the following upgrades:}

- Replace high use incandescent lamps with compact fluorescent lamps

- When replacing your electric clothes dryer, switch to natural gas model

- When replacing your clothes washer, choose an ENERGY STAR-labeled model

- When replacing your gas water heater, choose an energy efficient model

Note: The economic benefits for each of the upgrades below are evaluated in isolation from the other upgrades. If the efficiency level is changed for one upgrade, its potential impact on other upgrades will not be counted in the individual upgrade estimates. However, these kinds of interactions are included in the "package" totals associated with the whole-house totals and chart at the top of the page (above). For example, if the furnace efficiency is increased, the energy savings from wall insulation will not change in the table below, but the incrementa savings from including insulation in the package will be less due to the more efficient furnace's impact on reducing the energy required to make up heat losses through the wall (there is less energy being used, so less to save).

\section{Replace high use incandescent lamps with compact fluorescent lamps}

Economic Benefits:

Estimate Yearly Bill Savings:

Estimated Lifetime Energy

Savings:

Estimated Added Cost:

Maximum Price for 10 Year

Payback:

Return on Investment:

Upgrade Pays for Itself in:

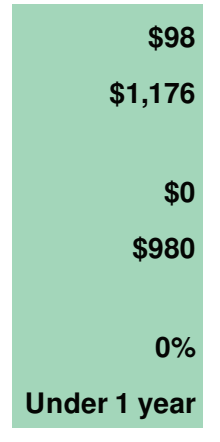

Additional Benefits:

Fluorescent lamps last several times longer than ordinary incandescent bulbs, which saves you the time and expense of replacing bulbs when they burn out.

\section{Upgrade Description:}

Replace high-use incandescent lamps with compact fluorescent lamps. These units can save up to $75 \%$ of the energy used by an ordinary incandescent bulb.

\section{Purchasing Tips:}

- Compare the light output in Lumens of the bulb you are replacing to ensure you are using the appropriate CFL.Most CFLs list their light output and equivalent incandescent wattage on their package.

- CFLs are available in many shapes and sizes, which will allow replacing nearly any incandescent bulb.

- When buying new light fixtures, look for ENERGY STAR qualified models.

- CFLs are a good investment for lights that are used 2-3 hours per day on average or more. 


\section{When replacing your electric clothes dryer, switch to natural gas model}

\section{Economic Benefits:}

Estimate Yearly Bill Savings:

Estimated Lifetime Energy

Savings:

Estimated Added Cost:

Maximum Price for 10 Year

Payback:

Return on Investment:

Upgrade Pays for Itself in:

\section{Additional Benefits:}

Natural gas clothes dryers reduce your home's peak load on the power grid compared to an electric dryer.

\section{Upgrade Description:}

When replacing your electric clothes dryer, select a natural gas model. In many situations, this willreduce your overall energy bill because natural gas tends to cost less than electricity, for the same heating value.

Note: Our calculations bill savings, typical upgrade costs, and cost-effectiveness are for a minimum-efficiency natural gas dryer model. The defaultupgrade cost provided here assumes that a natural gas connection is available at your clothes dryer. If this is not the case, be sure to include the costof extending

\section{Purchasing Tips:}

- To use a gas dryer, your laundry room must have a gas hookup, with proper connections and safe venting of the gas's exhaust, in addition to an electrical outlet

- Look for a dryer with a moisture sensor, and use the dryness settings rather than timed drying.

- When replacing your clothes washer, choose a model with high-speed spin cycles. This feature removes more water from clothes, which reduces the energy and time required for drying.

\section{More Information:}

- General Information from DOE

- Laundry tips from ACEEE

- Information from the California Energy Commission

\section{When replacing your clothes washer, choose an ENERGY STAR-labeled model}

Economic Benefits:

Estimate Yearly Bill Savings:

Estimated Lifetime Energy Savings:

Estimated Added Cost:

Maximum Price for 10 Year Payback:

Return on Investment:

Upgrade Pays for Itself in:

\section{Additional Benefits:}

ENERGY STAR® clothes washers can reduce water use significantly, leave the clothes drier thus reducing drying time and energy consumption, and reduce wear and tear on clothes.

\section{Upgrade Description:}

When replacing your clothes washer, choose an ENERGY STAR-labeled model. ENERGY STAR clothes washers can reduce energy consumption by up to $70 \%$ and are available in top-loading and front-loading designs. Some ENERGY STAR models use up to $50 \%$ less water in addition to saving energy.

Note: Our calculations bill savings, typical upgrade costs, and cost-effectiveness are for a model with the lowest efficiency that qualifies for the ENERGY STAR label. 
- Choose a clothes washer with high-speed spin cycles. This feature removes more water from clothes, which reduces the energy and time required for drying.

- Select a low water-use, high efficiency washer. Front-loading tumble-action washers can cut energy use by up to 70 percent, reduce water consumption significantly, and may actually get clothes cleaner. 1

- Look for pre-soaking and/or "suds saver" options which conserve energy.

- Clothes washers come with EnergyGuide yellow and black labels. Use these labels to select the most efficient model for the capacity you have chosen.

\section{More Information:}

- ENERGY STAR clothes washer product list

- General Information from DOE

- Top-Rated Energy-Efficient Clothes Washers from ACEEE

[Return to upgrades list

When replacing your gas water heater, choose an energy efficient model

\section{Economic Benefits:}

Estimate Yearly Bill Savings:

Estimated Lifetime Energy

Savings:

Estimated Added Cost:

Maximum Price for 10 Year

Payback:

Return on Investment:

Upgrade Pays for Itself in:

$\$ 48$

$\$ 576$

$\$ 170$

$\$ 480$

4 years

\section{Additional Benefits:}

Efficient gas-fired water heaters may hold their temperature longer following power interruptions and operate more safely.

\section{Upgrade Description:}

When replacing your gas water heater, choose an energy-efficient model with an Energy Factor of 0.62 or higher.

Note: Our calculations bill savings, typical upgrade costs, and cost-effectiveness assume the efficient water heater has an energy factor of 0.62 and recovery efficiency of 0.76 . Higher efficiency units are available, and would provide additional energy savings.

\section{Purchasing Tips:}

- The most important measure of efficiency for water heaters is the Energy Factor EF. The higher the EF, the more efficient the water heater.

- Purchase a water heater whose tank is internally insulated with at least R-16. $\underline{5}$

- A water heater that is too large for your home not only has a higher purchase cost but will increase your energy costs due to excessive cycling and standby losses. The resources below provide good, simple guidance on proper sizing of water heaters. The size, or "capacity", of a fuel-fired water heater should be judged by its first hour rating FHR, not its tank size. Due to larger burners, some gas water heaters with smaller tanks actually have higher capacities FHRs than models with larger tanks.

- Many types of water heaters are now available, such as "demand" tankless, "indirect" or "integrated", and solar-assisted water heaters. More Information

- New and/or efficient gas water heaters may have different venting and flue requirements. When replacing your water heater make sure your contractor assesses your existing flue, follows new code requirements for venting water heaters, and obtains necessary permits and inspections. $\frac{3}{3}$

\section{More Information:}

- General Information from DOE

- DOE Water Heating fact sheet

- Top-Rated Energy-EfficientWater Heaters from ACEEE

- GAMA consumer's directory click on "Consumers"

- How to prevent health and safety problems with combustion equipment 
ROADMAP TO RESULTS

Ease into the process of making your home more efficient. If you're new to this, or you're on a very tight budget, start with the lowest-hanging fruit like double-checking your water heater's temperature setting.

The next easy steps are simple things that will fit into your shopping basket: maybe a few compact fluorescent lamps or a roll of weatherstripping.

When it's time to replace that old fridge, or other appliances, take time to shop smart. At a minimum, look for the ENERGY STAR rating. There are detailed lists of products that will take you even farther. Remember: you're not simply spending money, you're investing for profit and comfort.

Redoing your kitchen? New roof? Finally adding that in-law unit? Creating successful projects can take some work. Take the time to find a home performance specialist to help you think thru all the options ahead of time, and then find the right contractor with the skills to do the job right.

Not only will these upgrades pay for themselves many times over, there are all kinds of financial incentives to help you trim the cost. And many of the "non-energy benefits" will be worth more than money can buy.

And, don't forget about saving water (which also saves energy).

Stumped? Ask an expert.

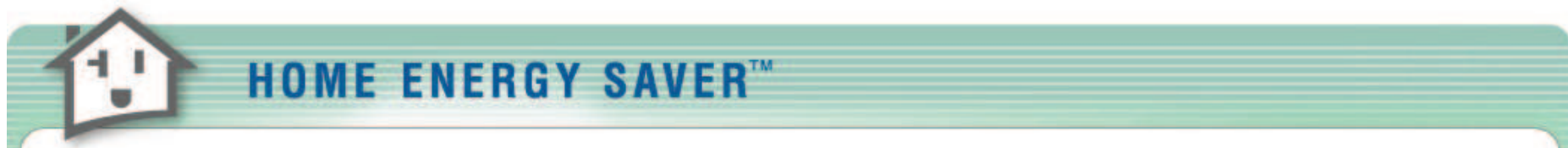

\section{DISCLAIMER}

The Home Energy Saver website and related content were prepared as an account of or to expedite work sponsored at least in part by the United States Government. While we strive to provide correct information, neither the United States Government nor any agency thereof, nor The Regents of the University of California, nor any of their employees, makes any warranty, express or implied, or assumes any legal responsibility for the accuracy, completeness, or usefulness of any information, apparatus, product, or process disclosed, or represents that its use would not infringe privately owned rights. Reference herein to any specific commercial product, process, or service by its trade name, trademark, manufacturer, or otherwise, does not necessarily constitute or imply its endorsement, recommendation, or favoring by the United States Government or any agency thereof, or The Regents of the University of California. Use of the Laboratory or University's name for endorsements is prohibited. The views and opinions of authors expressed herein do not necessarily state or reflect those of the United States Government or any agency thereof or The Regents of the University of California. Neither Berkeley Lab nor its employees are agents of the US Government.

Berkeley Lab web pages link to many other websites. Such links do not constitute an endorsement of the content or company and we are not responsible for the content of such links.

\section{Information That You Voluntarily Provide}

We do not collect personal information unless you choose to provide it to us. If you provide us with personal information, for example your address, we use that information to provide better information to you through the Home Energy Saver, as well as to further our research. While we strive to protect your personal information, our Laboratory conducts open fundamental research and cannot guarantee or warrant that your information will never be compromised or disclosed.

\section{How Information is Used}

The information you provide on this site is used to provide the service to you, to improve the service, and to conduct and support research by Berkeley Lab researchers and their collaborators.

\section{Information Protection}

For site security purposes and to ensure that this service remains available to all users, this University of California computer system employs software programs to monitor network traffic to identify unauthorized attempts to upload or change information, or otherwise cause damage. If such monitoring reveals evidence of possible abuse or criminal activity, such evidence may be provided to appropriate law enforcement officials. We may also share this information with other affiliated institutions in order to help secure other systems and networks. Unauthorized attempts to upload or change information on this server are strictly prohibited and may be punishable under California and Federal law.

\section{Sharing of Information}

We may share the information you choose to provide to us with our research collaborators and our partners who help to provide this service. We may share the information you provide to us with the Department of Energy and other Federal Agencies. Information you share with us may also be covered by California and Federal laws that provide for mandatory disclosure under certain circumstances, such as subpoenas and records requests.

A full description of the privacy policy and disclaimers can be found at the following web site 
Appendix D3 - Home Energy Saver Report - Alternatives Upgrades Configuration

\section{HOME ENERGY SAVER}

\section{HOME ENERGY SAVER \\ REPORT}

This report is generated by the Home Energy Saver

web-based energy audit tool, developed by

the U.S. Department of Energy's

Lawrence Berkeley National Laboratory,

and can be reached at http://hes.lbl.gov 


\section{HOUSE CONFIGURATION}

\section{General Information}

Name or other identifier this home/session : upgraded house 2; User's email address : delilahzoe@gmail.com; Purpose of this assessment : Hypothetical analysis; Address : 1276 Karen Road; Other text if other is checked : ; City : San Pablo; State : California; City with most similar climate to modeled house : Oakland; Year house was built : 1953; People living in the house, by age - 0 to 5 years : 0 ; People living in the house, by the age - 6-13:1; People living in the house, by the age - 14-64 : 2 ; People living in the house, by the age - 65 plus : 0; Check for actual electricity prices in your area. : no; Utilities List : ; Select your tariff from the list below. :

\section{Energy Prices}

Energy Prices - Electricity : 0.144; Energy Prices - Piped Natural Gas : 1.270; Energy Prices - Liquid Propane Gas (LPG) : 2.770; Energy Prices - Fuel Oil : 2.940

\section{Exterior Shading}

Extension of roof eaves or patios - Front : 1.00; Extension of roof eaves or patios - Right : 1.00; Extension of roof eaves or patios - Back : 1.00; Extension of roof eaves or patios - Left : 1.00; Height of large shade trees - Front : 0 ; Height of large shade trees - Right : 0; Height of large shade trees - Back : 0 ; Height of large shade trees - Left : 0; Height of neighboring houses stories - Front : One; Height of neighboring houses stories - Right : One; Height of neighboring houses stories - Back : One; Height of neighboring houses stories - Left : One;

\section{Air Tightness}

Does the house have weatherstripping : Yes; Enter the measured or estimated air leakage rate : 0.00;

\section{Foundation Floor}

Foundation type : Slab-on-grade Foundation; Foundation insulation level : None; Insulation level of the floor above the basement or crawlspace : R-0 (no insulation);

\section{Walls}

Darkness of exterior wall surfaces (left wall slider) : 0.70; Do all the walls have similar construction? : Yes; Darkness of exterior wall surfaces (right wall slider) : 0.70 Darkness of exterior wall surfaces (back wall slider) : 0.70; Darkness of exterior wall surfaces (slider) : 0.70; Wood Siding : ; Wood Siding : ; Wood Siding : ; Wood Siding : ; Stucco : ; Wood Siding : ; Stucco : ; Stucco : ; Stucco : ; Vinyl Siding : ; Stucco : ; Vinyl Siding : ; Vinyl Siding : ; Vinyl Siding : ; Aluminum Siding : ; Vinyl Siding : ; Aluminum Siding : ; Aluminum Siding : ; Aluminum Siding : ; Brick Veneer : ; Aluminum Siding : ; Brick Veneer : ; Brick Veneer : ; Brick Veneer : ; Wood Siding : ; Wood Siding : ; Brick Veneer : ; Wood Siding : ; Wood Siding: ; Stucco : ; Stucco : ; Wood Siding : ; Stucco : ; Stucco : ; Vinyl Siding : ; Vinyl Siding : ; Stucco : ; Vinyl Siding : ; Vinyl Siding : ; Aluminum Siding : ; Aluminum Siding :; Vinyl Siding : ; Aluminum Siding : ; Aluminum Siding : ; Brick Veneer : ; Brick Veneer :; Aluminum Siding : ; Brick Veneer : ; Brick Veneer : ; Wood Siding : ; Wood Siding : ; Brick Veneer : ; Wood Siding : ; Wood Siding : ; Stucco : ; Stucco : ; Wood Siding : ; Stucco : ; Stucco : ; Vinyl Siding : ; Vinyl Siding : ; Stucco : ; Vinyl Siding : ; Vinyl Siding : ; Aluminum Siding : ; Aluminum Siding : ; Vinyl Siding : ; Aluminum Siding : ; Aluminum Siding : ; Brick Veneer : ; Brick Veneer : ; Aluminum Siding :; Brick Veneer :; Brick Veneer : ; Wood Siding : ; Wood Siding : ; Brick Veneer : ; Wood Siding : ; Wood Siding :; Stucco : ; Stucco : ; Wood Siding : ; Stucco : ; Stucco : ; Vinyl Siding : ; Vinyl Siding : ; Stucco : ; Vinyl Siding : ; Vinyl Siding : ; Aluminum Siding : ; Aluminum Siding :; Vinyl Siding ; Aluminum Siding : ; Aluminum Siding : ; Brick Veneer : ; Brick Veneer : ; Aluminum Siding : ; Brick Veneer : ; Brick Veneer : ; Wood Siding : ; Wood Siding : ; Brick Veneer : ; Wood Siding : ; Wood Siding : ; Stucco : ; Stucco : ; Wood Siding : ; Stucco : ; Stucco : ; Vinyl Siding : ; Vinyl Siding : ; Stucco : ; Vinyl Siding : ; Vinyl Siding : ; Aluminum Siding : ; Aluminum Siding : ; Vinyl Siding : ; Aluminum Siding : ; Aluminum Siding : ; Brick Veneer : ; Brick Veneer : ; Aluminum Siding : ; Brick Veneer : ; Brick Veneer : ; Wood Siding : ; Wood Siding : ; Brick Veneer : ; Wood Siding : ; Wood Siding : ; Stucco : ; Stucco : ; Wood Siding : ; Stucco : ; Stucco : ; Vinyl Siding : ; Vinyl Siding: : Stucco : ; Vinyl Siding : ; Vinyl Siding : ; Aluminum Siding : ; Aluminum Siding : ; Vinyl Siding : ; Aluminum Siding : ; Aluminum Siding : ; Brick Veneer : ; Brick Veneer: ; Aluminum Siding : ; Brick Veneer : ; Brick Veneer : ; Wood Siding : ; Wood Siding : ; Brick Veneer : ; Wood Siding : ; Wood Siding : ; Stucco : ; Stucco : ; Wood Siding : ; Stucco : ; Stucco : ; Vinyl Siding : ; Vinyl Siding : ; Stucco : ; Vinyl Siding : ; Vinyl Siding : ; Aluminum Siding : ; Aluminum Siding : ; Vinyl Siding : ; Aluminum Siding: ; Aluminum Siding : ; Brick Veneer : ; Brick Veneer : ; Aluminum Siding : ; Brick Veneer : ; Brick Veneer : ; Wood Siding : ; Wood Siding : ; Brick Veneer : ; Wood Siding : ; Wood Siding : ; Stucco : ; Stucco :; Wood Siding : ; Stucco : ; Stucco : ; Vinyl Siding : ; Vinyl Siding : ; Stucco : ; Vinyl Siding : ; Vinyl Siding : ; Aluminum Siding : ; Aluminum Siding : ; Vinyl Siding : ; Aluminum Siding :; Aluminum Siding : ; Brick Veneer : ; Brick Veneer : ; Aluminum Siding : ; Brick Veneer : ; Brick Veneer : ; Wood Siding: ; Wood Siding : ; Brick Veneer : ; Wood Siding : ; Wood Siding : ; Stucco : ; Stucco : ; Wood Siding : ; Stucco : ; Stucco : ; Vinyl Siding : ; Vinyl Siding : ; Stucco : ; Vinyl Siding : ; Vinyl Siding : ; Aluminum Siding : ; Aluminum Siding : ; Vinyl Siding : ; Aluminum Siding : ; Aluminum Siding : ; Brick Veneer : ; Brick Veneer : ; Aluminum Siding : ; Brick Veneer : ; Brick Veneer :; Wood Siding : ; Wood Siding :; Brick Veneer :; Wood Siding :; Wood Siding :; Stucco : ; Stucco :; Wood Siding :; Stucco : ; Stucco : ; Vinyl Siding : ; Vinyl Siding : ; Stucco : ; Vinyl Siding : ; Vinyl Siding : ; Aluminum Siding : ; Aluminum Siding : ; Vinyl Siding : ; Aluminum Siding : ; Aluminum Siding : ; Brick Veneer : ; Brick Veneer : ; Aluminum Siding : ; Brick Veneer : ; Brick Veneer : ; Wood Siding : ; Wood Siding : ; Brick Veneer : ; Wood Siding : ; Wood Siding : ; Stucco : ; Stucco : ; Wood Siding : ; Stucco : ; Stucco : ; Vinyl Siding : ; Vinyl Siding : ; Stucco : ; Vinyl Siding : ; Vinyl Siding : ; Aluminum Siding : ; Aluminum Siding : ; Vinyl Siding : ; Aluminum Siding : ; Aluminum Siding : ; Brick Veneer : ; Brick Veneer : ; Aluminum Siding :; Brick Veneer : ; Brick Veneer : ; Wood Siding: ; Wood Siding : ; Brick Veneer : ; Wood Siding : ; Wood Siding : ; Stucco : ; Stucco : ; Wood Siding : ; Stucco : ; Stucco : ; Vinyl Siding : ; Vinyl Siding : ; Stucco : ; Vinyl Siding : ; Vinyl Siding : ; Aluminum Siding : ; Aluminum Siding : ; Vinyl Siding : ; Aluminum Siding : ; Aluminum Siding : ; Brick Veneer : ; Brick Veneer : ; Aluminum Siding : ; Brick Veneer : ; Brick Veneer : ; Wood Siding : ; Wood Siding : ; Brick Veneer : ; Wood Siding : ; Wood Siding : ; Stucco : ; Stucco : ; Wood Siding : ; Stucco : ; Stucco : ; Vinyl Siding : ; Vinyl Siding : ; Stucco : ; Vinyl Siding : ; Vinyl Siding : ; Aluminum Siding : ; Aluminum Siding : ; Vinyl Siding : ; Aluminum Siding : ; Aluminum Siding : ; Brick Veneer : ; Brick Veneer : ; Aluminum Siding : ; Brick Veneer : ; Brick Veneer : ; Wood Siding : ; Wood Siding : ; Brick Veneer : ; Wood Siding : ; Wood Siding : ; Stucco : ; Stucco : ; Wood Siding : ; Stucco : ; Stucco : ; Vinyl Siding : ; Vinyl Siding : ; Stucco : ; Vinyl Siding : ; Vinyl Siding : ; Aluminum Siding : ; Aluminum Siding : ; Vinyl Siding : ; Aluminum Siding: ; Aluminum Siding : ; Brick Veneer : ; Brick Veneer : ; Aluminum Siding : ; Brick Veneer : ; Brick Veneer : ; Wood Siding : ; Wood Siding : ; Brick Veneer : ; Wood Siding : ; Wood Siding : ; Stucco : ; Stucco : ; Wood Siding : ; Stucco : ; Stucco : ; Vinyl Siding : ; Vinyl Siding : ; Stucco : ; Vinyl Siding : ; Vinyl Siding : ; Aluminum Siding : ; Aluminum Siding : ; Vinyl Siding : ; Aluminum Siding : ; Aluminum Siding : ; Brick Veneer : ; Brick Veneer : ; Aluminum Siding ; Brick Veneer : ; Brick Veneer : ; Wood Siding : ; Wood Siding : ; Brick Veneer : ; Wood Siding : ; Wood Siding : ; Stucco : ; Stucco : ; Wood Siding : ; Stucco : ; Stucco ; Vinyl Siding : ; Vinyl Siding : ; Stucco : ; Vinyl Siding : ; Vinyl Siding : ; Aluminum Siding : ; Aluminum Siding : ; Vinyl Siding : ; Aluminum Siding : ; Aluminum Siding : ; Brick Veneer : ; Brick Veneer : ; Aluminum Siding : ; Brick Veneer : ; Brick Veneer : ; Wood Siding : ; Wood Siding : ; Brick Veneer : ; Wood Siding : ; Wood Siding : ; Stucco : ; Stucco : ; Wood Siding : ; Stucco : ; Stucco : ; Vinyl Siding : ; Vinyl Siding : ; Vinyl Siding : ; Stucco : ; Vinyl Siding : ; Aluminum Siding : ; Aluminum Siding : ; Aluminum Siding : ; Vinyl Siding : ; Aluminum Siding : ; Brick Veneer : ; Brick Veneer : ; Brick Veneer : ; Aluminum Siding : ; Brick Veneer : ; Wood Siding : ; Wood Siding ; Wood Siding : ; Brick Veneer : ; Wood Siding : ; Stucco : ; Stucco : ; Stucco : ; Wood Siding : ; Stucco : ; Vinyl Siding : ; Vinyl Siding : ; Vinyl Siding : ; Stucco : ; Vinyl Siding : ; Aluminum Siding : ; Aluminum Siding : ; Aluminum Siding : ; Vinyl Siding : ; Aluminum Siding : ; Brick Veneer : ; Brick Veneer : ; Brick Veneer : ; Aluminum Siding : ; Brick Veneer : ; Wood Siding : ; Wood Siding: ; Wood Siding : ; Brick Veneer : ; Wood Siding : ; Stucco : ; Stucco : ; Stucco : ; Wood Siding : ; Stucco : ; Vinyl Siding : ; Vinyl Siding : ; Vinyl Siding : ; Stucco : ; Vinyl Siding : ; Aluminum Siding : ; Aluminum Siding : ; Aluminum Siding : ; Vinyl Siding : ; Aluminum Siding : ; Brick Veneer : ; Brick Veneer : ; Brick Veneer : ; Aluminum Siding : ; Brick Veneer : ; Wood Siding : ; Wood Siding : ; Wood Siding : ; Brick Veneer : ; Wood Siding : ; Stucco : ; Stucco: ; Stucco : ; Wood Siding : ; Stucco : ; Vinyl Siding : ; Vinyl Siding : ; Vinyl Siding :; Stucco : ; Vinyl Siding : ; Aluminum Siding : ; Aluminum Siding :; Aluminum Siding : ; Vinyl Siding : ; Aluminum Siding : ; Brick Veneer : ; Brick Veneer : ; Brick Veneer : ; Aluminum Siding : ; Brick Veneer : ; Wood Siding : ; Wood Siding : ; Wood Siding : ; Brick Veneer : ; Wood Siding : ; Stucco : ; Stucco : ; Stucco : ; Wood Siplog; Stucco : ; Vinyl Siding : ; Vinyl Siding : ; Vinyl Siding : ; Stucco : ; Vinyl Siding : ; Aluminum Siding:; Aluminum Siding : ; Aluminum Siding : ; Vinyl Siding : ; Aluminum Siding : ; Brick Veneer : ; Brick Veneer : ; Brick Veneer : ; Aluminum Siding :; Brick 
Veneer : ; Wood Siding : ; Wood Siding : ; Wood Siding : ; Brick Veneer : ; Wood Siding : ; Stucco : ; Stucco:

Siding : ; Vinyl Siding : ; Stucco : ; Vinyl Siding : ; Aluminum Siding : ; Aluminum Siding : ; Aluminum Siding :; Vinyl Siding :;Alum Brick Veneer: ; Wood Siding : ; Stucco : ; Stucco : ; Stucco : ; Wood Siding : ; Stucco : ; Vinyl Siding : ; Vinyl Siding : ; Vinyl Siding : ; Stucco : ; Vinyl Siding : ; Aluminum Siding : ; Aluminum Siding : ; Aluminum Siding : ; Vinyl Siding : ; Aluminum Siding : ; Brick Veneer : ; Brick Veneer : ; Brick Veneer : ; Aluminum Siding : ; Brick Veneer : ; Wood Siding : ; Wood Siding : ; Wood Siding :; Brick Veneer : ; Wood Siding : ; Stucco : ; Stucco : ; Stucco : ; Wood Siding : ; Stucco : ; Vinyl Siding : ; Vinyl Siding : ; Vinyl Siding : ; Stucco : ; Vinyl Siding : ; Aluminum Siding :; Aluminum Siding : ; Aluminum Siding : ; Vinyl Siding : ; Aluminum Siding : ; Brick Veneer : ; Brick Veneer: ; Brick Veneer : ; Aluminum Siding:; Brick Veneer : ; Wood Siding : ; Wood Siding : ; Wood Siding : ; Brick Veneer : ; Wood Siding : ; Stucco : ; Stucco :; Stucco : ; Wood Siding : ; Stucco : ; Vinyl Siding : ; Vinyl Siding : ; Vinyl Siding : ; Stucco : ; Vinyl Siding : ; Aluminum Siding : ; Aluminum Siding : ; Aluminum Siding :; Vinyl Siding : ; Aluminum Siding : ; Brick Veneer : ; Brick Veneer : ; Brick Veneer : ; Aluminum Siding : ; Brick Veneer : ; Wood Siding : ; Wood Siding : ; Wood Siding : ; Brick Veneer:; Wood Siding : ; Stucco : ; Stucco : ; Stucco : ; Wood Siding : ; Stucco : ; Vinyl Siding : ; Vinyl Siding : ; Vinyl Siding : ; Stucco : ; Vinyl Siding :; Aluminum Siding : ; Aluminum Siding : ; Aluminum Siding : ; Vinyl Siding : ; Aluminum Siding : ; Brick Veneer : ; Brick Veneer : ; Brick Veneer : ; Aluminum Siding : ; Brick Veneer:; Wood Siding:; Wood Siding : ; Wood Siding :; Brick Veneer : ; Wood Siding : ; Stucco : ; Stucco : ; Stucco : ; Wood Siding : ; Stucco : ; Vinyl Siding : ; Vinyl Siding : ; Vinyl Siding : ; Stucco : ; Vinyl Siding : ; Aluminum Siding :; Aluminum Siding :; Aluminum Siding : ; Vinyl Siding :; Aluminum Siding : ; Brick Veneer : ; Brick Veneer : ; Brick Veneer : ; Aluminum Siding : ; Brick Veneer : ; Wood Siding : ; Wood Siding : ; Wood Siding : ; Brick Veneer : ; Wood Siding : ; Stucco : ; Stucco : ; Stucco : ; Wood Siding : ; Stucco : ; Vinyl Siding : ; Vinyl Siding : ; Vinyl Siding : ; Stucco : ; Vinyl Siding : ; Aluminum Siding : ; Aluminum Siding : ; Aluminum Siding : Vinyl Siding : ; Aluminum Siding : ; Brick Veneer : ; Brick Veneer : ; Brick Veneer : ; Aluminum Siding : ; Brick Veneer : ; Wood Siding : ; Wood Siding : ; Wood Siding : ; Brick Veneer : ; Wood Siding : ; Stucco : ; Stucco : ; Stucco : ; Wood Siding : ; Stucco : ; Vinyl Siding : ; Vinyl Siding : ; Vinyl Siding : ; Stucco : ; Vinyl Siding :; Aluminum Siding : ; Aluminum Siding : ; Aluminum Siding : ; Vinyl Siding : ; Aluminum Siding : ; Brick Veneer : ; Brick Veneer : ; Brick Veneer : ; Aluminum Siding : ; Brick Veneer : ; Wood Siding : ; Wood Siding : ; Wood Siding : ; Brick Veneer : ; Wood Siding : ; Stucco : ; Stucco : ; Stucco : ; Wood Siding : ; Stucco : ; Vinyl Siding : ; Vinyl Siding : ; Vinyl Siding : ; Stucco : ; Vinyl Siding : ; Aluminum Siding:; Aluminum Siding : ; Aluminum Siding : ; Vinyl Siding : ; Aluminum Siding : ; Brick Veneer : ; Brick Veneer : ; Brick Veneer : ; Aluminum Siding : ; Brick Veneer : ; Wood Siding : ; Wood Siding : ; Wood Siding : ; Brick Veneer : ; Wood Siding : ; Stucco : ; Stucco : ; Stucco : ; Wood Siding : ; Stucco : ; Vinyl Siding : ; Vinyl Siding : ; Vinyl Siding : ; Stucco : ; Vinyl Siding : ; Aluminum Siding : ; Aluminum Siding : ; Aluminum Siding : ; Vinyl Siding : ; Aluminum Siding : ; Brick Veneer : ; Brick Veneer : ; Brick Veneer : ; Brick Veneer : ; Aluminum Siding : ; Wood Siding : ; Wood Siding : ; Wood Siding : ; Wood Siding : ; Brick Veneer : ; Stucco : ; Stucco : ; Stucco : ; Stucco : ; Wood Siding : ; Vinyl Siding : ; Vinyl Siding : ; Vinyl Siding : ; Vinyl Siding : ; Stucco : ; Aluminum Siding : ; Aluminum Siding : ; Aluminum Siding : ; Aluminum Siding : ; Vinyl Siding : ; Brick Veneer : ; Brick Veneer : ; Brick Veneer : ; Brick Veneer :; Aluminum Siding : ; R-0 (no insulation) : ; R-0 (no insulation) : ; R-0 (no insulation) : ; R-0 (no insulation) : ; Brick Veneer : ; R-5 (1 inch) : ; R-5 (1 inch) : ; R-5 (1 inch) : ; R-5 (1 inch) : ; R-0 (no insulation) : ; R-10 (2 inches) : ; R-10 (2 inches) : ; R-10 (2 inches) : ; R-10 (2 inches) : ; R-5 (1 inch) : ; Stucco : ; Stucco : ; Stucco : ; Stucco : ; R-10 (2 inches) : ; Brick : ; Brick : ; Brick : ; Brick : ; Stucco : ; None : ; None : ; None : ; None : ; Brick : ; Stucco : ; Stucco : ; Stucco : ; Stucco : ; None : ; Brick : ; Brick : ; Brick :; Brick : ; Stucco : ; None : ; None : ; None : ; None : ; Brick : ; Stucco : ; Stucco : ; Stucco : ; Stucco : ; None : ; Brick : ; Brick : ; Brick : ; Brick : ; Stucco : ; None : ; None : ; None : ; None : ; Brick : ; R-0 (no insulation) : ; R-0 (no insulation) : ; R-0 (no insulation) : ; R-0 (no insulation) : ; None : ; R-0 (no insulation) : ;

\section{Doors Windows}

Doors - Front of house - Number of doors each wall : 1 door; Doors - Front of house - Door Type : Uninsulated wood/wood/wood; Doors - Front of house - Door U-Factor 0.00; Doors - Right side of house - Number of doors each wall : 0 doors; Doors - Right side of house - Door Type : Uninsulated wood/wood/wood; Doors - Right side of house - Door U-Factor : 0.00; Doors - Back of house - Number of doors each wall : 1 door; Doors - Back of house - Door Type : Uninsulated wood/wood/wood; Doors Back of house - Door U-Factor : 0.00; Doors - Left side of house - Number of doors each wall : 1 door; Right : Interior Drapes; Doors - Left side of house - Door Type : Custom door (enter U-Factor below); Back : Interior Drapes; Doors - Left side of house - Door U-Factor : 1.30; Left : Interior Drapes; Windows - Does the house have diff types of windows on each side : No; Single-pane, clear" 15 heat_cool_input windowTypeFront Detailed Doors-Windows windowTypeFront sp-tinted-a radio 0 scna stna "Single-pane, tinted" 16 heat_cool input windowTypeFront Detailed Doors-Windows windowTypeFront dp-clear-a radio 0 scna : ; Single-pane, tinted : ; Double-pane, clear : ; Double-pane, tinted : ; Double-pane, solar-control low-E : ; Double-pane, clear : ; Double-pane, tinted : ; Single-pane, clear : ; Double-pane, solar-control low-E : ; Custom window : ; Single-pane, tinted : ; Double-pane, insulating low-E, argon gas fill : ; Custom window : ; Double-pane, clear : ; Single-pane, clear : ; Custom window : ; Doublepane, tinted : ; Single-pane, tinted : ; Custom window : ; Double-pane, solar-control low-E : ; Double-pane, clear : ; Double-pane, clear : ; Double-pane, tinted : ; Doublepane, tinted : ; Double-pane, solar-control low-E : ; Double-pane, solar-control low-E : ; Double-pane, solar-control low-E, argon gas fill : ; Double-pane, insulating low-E, argon gas fill : ; Double-pane, insulating low-E : ; Single-pane, clear : ; Double-pane, insulating low-E, argon gas fill : ; Single-pane, tinted : ; Triple-pane, insulating low-E, argon gas fill : ; Double-pane, clear : ; U-Factor (0.00:5.00) : 1.30; Double-pane, tinted : 1.30; Solar heat gain coefficient (0.00:1.00) : 0.90; Double-pane, solar-control low-E : 0.90; Window Area Front : 48.02; Double-pane, solar-control low-E, argon gas fill : ; Window Area Right : 20.97; Double-pane, insulating low-E : 20.97; Window Area Back : 30.17; Double-pane, insulating low-E, argon gas fill : 30.17; Window Area Left : 57.68; Triple-pane, insulating low-E, argon gas fill : 57.68 ; Movable Insulation Front : 0.00; U Factor (0.00:5.00) : 0.00; Movable Insulation Right : 0.00; Solar heat gain coefficient (0.00:1.00) : 0.00; Movable Insulation Back : 0.00; Single-pane, clear : 0.00; Movable Insulation Left : 0.00; Single-pane, tinted : 0.00; Movable Shades Front : Interior Drapes; Double-pane, clear : Interior Drapes; Movable Shades Right : Interior Drapes; Double-pane, tinted : Interior Drapes; Movable Shades Back : Interior Drapes; Double-pane, solar-control low-E : Interior Drapes; Movable Shades Left : Interior Drapes; Double-pane, clear : Interior Drapes; Double-pane, tinted : Interior Drapes; Double-pane, solar-control low-E : Interior Drapes; Double-pane, insulating low-E, argon gas fill : Interior Drapes; Single-pane, clear : Interior Drapes; Single-pane, tinted : Interior Drapes; Double-pane, clear : Interior Drapes; Double-pane, tinted : Interior Drapes; Double-pane, solar-control low-E : Interior Drapes; Double-pane, solar-control low-E, argon gas fill : ; Double-pane, insulating low-E : ; Double-pane, insulating low-E, argon gas fill : ; Triple-pane, insulating low-E, argon gas fill : ; U-Factor (0.00:5.00) : 0.00; Solar heat gain coefficient (0.00:1.00) : 0.00; Single-pane, clear : 0.00; Single-pane, tinted : 0.00; Double-pane, clear : 0.00; Double-pane, tinted : 0.00; Double-pane, solar-control low-E : 0.00; Double-pane, clear : 0.00; Double-pane, tinted : 0.00; Double-pane, solar-control low-E : 0.00; Double-pane, insulating low-E, argon gas fill : 0.00; Single-pane, clear : 0.00; Single-pane, tinted : 0.00; Double-pane, clear : 0.00; Double-pane, tinted : 0.00; Double-pane, solar-control low-E : 0.00; Double-pane, solar-control low-E, argon gas fill : ; Double-pane, insulating low-E : ; Double-pane, insulating low-E, argon gas fill : ; Triple-pane, insulating low-E, argon gas fill : ; U-Factor $(0.00: 5.00)$ : 0.00; Solar heat gain coefficient (0.00:1.00) : 0.00 ;

\section{Attic Roof}

Attic or ceiling type : Unconditioned Attic; Insulation level of the attic floor : R-19 (7-9 inches); R-0 (no insulation) : ; R-11 (3-5 inches) : ; R-13 (5-6 inches) : ; R-15 (6-7 inches) : ; R-19 (7-9 inches) : ; R-21 (9-10 inches) : ; R-0 (no insulation) : ; R-11 (3-5 inches) : ; R-13 (5-6 inches) : ; R-15 (6-7 inches) : ; R-19 (7-9 inches) : ; R-21 (9-10 inches) : ; R-27 (10-13 inches) : ; R-0 (no insulation) : ; R-11 (3-5 inches) : ; R-13 (5-6 inches) : ; R-15 (6-7 inches) : ; R-19 (7-9 inches) : ; R-21 (9-10 inches) : ; R-27 (10-13 inches) : ; R-0 (no insulation) : ; R-11 (3-5 inches) : ; R-13 (5-6 inches) : ; R-15 (6-7 inches) : ; R-19 (7-9 inches) : ; R-21 (9-10 inches) : ; R-27 (10-13 inches) : ; R-0 (no insulation) : ; R-11 (3-5 inches) : ; R-13 (5-6 inches) : ; R-15 (6-7 inches) : ; R-19 (7-9 inches) : ; R-21 (9-10 inches) : ; R-27 (10-13 inches) : ; R-0 (no insulation) : ; R-0 (no insulation) : ; R-0 (no insulation) : ; R-0 (no insulation) : ; R-0 (no insulation) : ; R-0 (no insulation) : ; R-11 (3-5 inches) : ; R-13 (5-6 inches) : ; R-15 (6-7 inches) : ; R-0 (no insulation) : ; R-11 (3-5 inches) : ; R-13 (5-6 inches) : ; R-15 (6-7 inches) : ; R-19 (7-9 inches) : ; R-21 (9-10 inches) : ; R-0 (no insulation) : ; R-11 (3-5 inches) : ; R-13 (5-6 inches) : ; R-15 (6-7 inches) : ; R-19 (7-9 inches) : ; R-21 (9-10 inches) : ; R-0 (no insulation) : ; R-11 (3-5 inches) : ; R-13 (5-6 inches) : ; R-15 (6-7 inches) : ; R-19 (7-9 inches) : ; R-21 (9-10 inches) : ; R-0 (no insulation) : ; R-11 (3-5 inches) : ; R-13 (5-6 inches) : ; R-15 (6-7 inches) : ; R-19 (7-9 inches) : ; R-21 (9-10 inches) : ; Slider : 0.800; User-entered exterior roof absorptance : 0.800 ; Slope (or pitch) of roof : $3: 12$ (14 degrees);

\section{Ducts Pipes}

Duct location : Unknown/not applicable; Are the ducts insulated? : No/Don't Know; Are the ducts sealed? : No/Don't Know; Are the boiler pipes insulated? : No/Don't Know; Does the boiler also provide the hot tap water? : No - I have a separate boiler and water heater. ;

\section{Thermostat}

Settings changed during the day and evening : Change; Standard or Programmable Thermostat : programmable; Temperature setting - Heating temperature : 64; Temperature setting - Cooling temperature : 81; Weekdays Heating Day Degrees : 64; Weekdays Heating Day Time : 8; Weekdays Heating Night Degrees : 68; Weekdays Heating Night Time : 17; Weekdays Cooling Day Degrees : 81; Weekdays Cooling Day Time : 8; Weekdays Cooling Night Degrees : 78; Weekdays Cooling Night Time : 17; Weekend/Holiday Heating Day Degrees : 64; Weekend/Holiday Heating Day Time; 8: Weekend/Holiday Heating Night Degrees : 68; Weekend/Holiday Heating Night Time: 17; Weekend/Holiday Cooling Day Degrees : 81; Weekend/Holiday Cooling Day Tih 30 ; Weekend/Holiday Cooling Night Degrees : 78; Weekend/Holiday Cooling Night 
Time : 17; Temperature setting - Heating temperature : 8; Temperature setting - Cooling temperature : 8; Weekdays Heating Wake degrees : 68; Weekdays Heating Wake Time : 7; Weekdays Heating Away degrees : 64; Weekdays Heating Away Time : 9; Weekdays Heating Evening degrees : 68; Weekdays Heating Evening Time : 19; Weekdays Heating Sleep degrees : 64; Weekdays Heating Sleep Time : 23; Weekdays Cooling Wake degrees : 78; Weekdays Cooling Wake Time : 7; Weekdays Cooling Away degrees : 81; Weekdays Cooling Away Time : 9; Weekdays Cooling Evening degrees : 78; Weekdays Cooling Evening Time : 19; Weekdays Cooling Sleep degrees 81; Weekdays Cooling Sleep Time : 23; Weekend/Holiday Heating Wake degrees : 68; Weekend/Holiday Heating Wake Time : 8; Weekend/Holiday Heating Away degrees : 64; Weekend/Holiday Heating Away Time : 11; Weekend/Holiday Heating Evening degrees : 68; Weekend/Holiday Heating Evening Time : 19; Weekend/Holiday Heating Sleep degrees : 64; Weekend/Holiday Heating Sleep Time : 23; Weekend/Holiday Cooling Wake degrees : 78; Weekend/Holiday Cooling Wake Time : 8; Weekend/Holiday Cooling Away degrees : 81; Weekend/Holiday Cooling Away Time : 11; Weekend/Holiday Cooling Evening degrees : 78; Weekend/Holiday Cooling Evening Time : 19; Weekend/Holiday Cooling Sleep degrees : 81; Weekend/Holiday Cooling Sleep Time : 23;

\section{Heating Equipment}

Type of heating system : Room (through-the-wall) gas furnace; Heating system capacity : 60000; Heating system efficiency : $\mathbf{5 0 . 0 0 ; ~ Y e a r ~ h e a t i n g ~ s y s t e m ~ i n s t a l l e d ~ : ~}$ 1970; Percentage of the house's floor area heated by a central or room heating system : 19; Percentage of the house's heating needs supplied by a wood burning stove or portable heater : 37 ;

\section{Cooling Equipment}

Type of cooling system : No Cooling Equipment; Cooling system capacity : 0; Cooling system efficiency : 0.00; Year cooling system installed : 1970; Percentage of the house's floor area cooled by the cooling system : 100; Hours room air conditioner is on during an average day in the cooling season : None; Number of months room air conditioner is on during an average cooling season ? : None; Does the house have ceiling fans? : Yes; Number of ceiling fans : 5 ; Does the house have a whole-house fan? No; Hours per day the whole-house fan is used : $\mathbf{0}$; Months per year the whole-house fan is used : $\mathbf{0}$; Does the house have portable fans? : Yes; Number of portable fans : 1

\section{Water Heating}

Water heater fuel : Piped Natural Gas; Year purchased : Piped Natural Gas; Does occupant pay for water heater fuel? : Yes; Is an adult at home on weekdays? : Yes; Energy Factor : 0.55; Recovery Efficiency : 0.76; Rated Input : 38000.00; Storage tank capacity (gallons) : 50; Temperature Setting : Medium-Low; Water heater location : Outdoors;

\section{Lighting}

Kitchen : 2; Kitchen Bulb Type : Halogen Tochiere; Kitchen Number of bulbs in fixture : $\mathbf{1}^{\wedge} \mathbf{1 ; 2} \mathbf{2}^{\wedge} \mathbf{1}$; Kitchen Sum of wattages for all bulbs in fixture : $\mathbf{1}^{\wedge} 60 ; 2^{\wedge} 60 ;$ Kitchen Usage (Hrs/day) : 1; Dining Room : 0; Dining Room Bulb Type : ; Dining RoomNumber of bulbs in fixture : ; Dining RoomSum of wattages for all bulbs in fixture : ; Dining RoomUsage (Hrs/day) : ; Living Room : 3; Living Room Bulb Type : Halogen Tochiere; Living Room Number of bulbs in fixture : 1^1;2^1;3^1; Living Room Sum of wattages for all bulbs in fixture : $1^{\wedge} 60 ; 2^{\wedge} 60 ; 3^{\wedge} 60$; Living Room Usage (Hrs/day) : 1; Family Room : 0; Family Room Bulb Type : ; Family Room Number of bulbs in fixture : ; Family Room Sum of wattages for all bulbs in fixture : ; Family Room Usage (Hrs/day) : ; Master Bedroom : 3; Master Bedroom Bulb Type : Halogen Tochiere; Master Bedroom Number of bulbs in fixture : $1^{\wedge} 1 ; 2^{\wedge} 1 ; 3^{\wedge} 1$; Master BedroomSum of wattages for all bulbs in fixture : $1^{\wedge} 65 ; 2^{\wedge} 65 ; 3^{\wedge} 65 ;$ Master Bedroom Usage (Hrs/day) : 1; Hall : 0; Hall Bulb Type : ; Hall Number of bulbs in fixture : ; Hall Sum of wattages for all bulbs in fixture : ; Hall Usage (Hrs/day) : ; All Bedrooms : 1; All Bedrooms Bulb Type : Halogen Tochiere; All Bedrooms Number of bulbs in fixture : 1^1; All Bedrooms Sum of wattages for all bulbs in fixture : 1^60; All Bedrooms Usage (Hrs/day) : 1; All Bathrooms : 4; All Bathrooms Bulb Type : Halogen Tochiere; All Bathrooms Number of bulbs in fixture : $1^{\wedge} 1 ; 2^{\wedge} 1 ; 3^{\wedge} 1 ; 4^{\wedge} 1 ;$ All Bathrooms Sum of wattages for all bulbs in fixture : $1^{\wedge} 60 ; 2^{\wedge} 60 ; 3^{\wedge} 14 ; 4^{\wedge} 14$; All Bathrooms Usage (Hrs/day) : 1; All Closets : 0; All Closets Bulb Type : ; All Closets Number of bulbs in fixture : ; All Closets Sum of wattages for all bulbs in fixture : ; All Closets Usage (Hrs/day) : ; Utility Room : 1; Utility Room Bulb Type : ; Utility Room Number of bulbs in fixture : ; Utility Room Sum of wattages for all bulbs in fixture : ; Utility Room Usage (Hrs/day) : ; Garage : 0; Garage Bulb Type : ; Garage Number of bulbs in fixture : ; Garage Sum of wattages for all bulbs in fixture : ; Garage Usage (Hrs/day) : ; Outdoor Lighting : 5; Outdoor Lighting Bulb Type : Halogen Tochiere; Outdoor Lighting Number of bulbs in fixture : $1^{\wedge} 1 ; 2^{\wedge} 1 ; 3^{\wedge} 1 ; 4^{\wedge} 1 ; 5^{\wedge} 1$; Outdoor Lighting Sum of wattages for all bulbs in fixture : $1^{\wedge} 120 ; 2^{\wedge} 120 ; 3^{\wedge} 120 ; 4^{\wedge} 120 ; 5^{\wedge} 120$; Outdoor Lighting Usage (Hrs/day) : 1; Other : 0; Other Bulb Type : ; Other Number of bulbs in fixture : ; Other Sum of wattages for all bulbs in fixture : ; Other Usage (Hrs/day) :

\section{Refrigerators Freezers}

Year made : ; Size : Large (19-21 cu ft); Type : Large (19-21 cu ft); Energy Star : Yes; Year made : present; Size : present; Type : present; Energy Star : No; Year made present; Size : present; Type : present; Energy Star : No; Year made : present; Size : present; Type : present; Year made : present; Size : present; Type : present;

\section{Cooking Dishwashing}

Stove fuel : Natural Gas or Propane; hours per day stove used : 1 hour; Pilot Light : No; Oven fuel : Electricity; Hours per week oven used : 2 hours; Pilot Light : No; Does house have/use a dishwasher : Yes; Energy Start Qualified : Yes; Loads washed per week : 4;

\section{Laundry}

Does house have/use a clothes washer? : Yes; ENERGY STAR Qualified : Yes; Hot/Warm : 2; Hot/Cold : 0; Warm/Warm : 3; Warm/Cold : 2; Cold/Cold : 0; Dryer fuel : Electricity; Number of loads dried per week : 3;

\section{HotTubs Spas Pumps}

How many hours/day does the pool pump run? : House doesn't have a pool pump; How many months of the year does the pool pump run? : 0 ; Is there a pool heater? No; How is the spa heated? : House doesn't have a spa/hot tub; If spa is heated only when it is being used, how many hours per week is it used?" 6 major appliance input sumpPumpSize Detailed HotTubs-Spas-Pumps sumpPumpSize sump-pump-size 0 values:1-4 What is the size of the sump pump? 7 major_appliance_input : $\mathbf{0}$; What is the size of the sump pump? : House doesn't have a sump/sewage pump; How many hours/year does the sump operate? : 5 hours/year; Indicate the vertical distance that water is lifted. : House doesn't have a well pump; Combined pump and motor efficiency : Typical - 40\%; Is house water pressure provided by gravity or pump? : Pump; How much water is used outdoors? : Roughly 5 min/day with garden hose;

\section{Entertainment}

Number of Units : 1; Average Per-unit Use : 2; Unit of Time : Hours; Unit of Calendar : Day; Energy Star? : No; Number of Units : 0; Average Per-unit Use : 2; Unit of Time : Hours; Unit of Calendar : Day; Number of Units : 0; Average Per-unit Use : 2; Unit of Time : Hours; Unit of Calendar : Day; Number of Units : 0; Average Per-unit Use : 2; Unit of Time : 2; Unit of Calendar : Day; Number of Units : 0; Average Per-unit Use : 2; Unit of Time : Hours; Unit of Calendar : Day; Number of Units : 1; Average Per-unit Use : 4; Unit of Time : Hours; Unit of Calendar : Week; Energy Star? : No; Number of Units : 1; Average Per-unit Use : 2; Unit of Time : Hours; Unit of Calendar : Week; Energy Star? : No; Number of Units : 1; Average Per-unit Use : 1; Unit of Time : Minutes; Unit of Calendar : Day; Number of Units : 0; Average Per-unit Use : 0; Unit of Time : Minutes; Unit of Calendar : Day; Number of Units : 1; Average Per-unit Use : 1; Unit of Time : Hours; Unit of Calendar : Day; Number of Units : 1; Average Per-unit Use : 2; Unit of Time : Hours; Unit of Calendar : Week; Number of Units : 1; Average Per-unit Use : 30; Unit of Time : Minutes; Unit of Calendar : Week; Number of Units : 1; Average Per-unit Use : 30; Unit of Time : Minutes; Unit of Calendar : Week; Energy Star : No; Number of Units : 1; Average Per-unit Use : 2; Unit of Time : Hours; Unit of Calendar: Week;

\section{Home Office}

Number of Units : 1; Average Per-unit Use : 5; Unit of Time : Hours; Unit of Calendar : Day; Number of Units : 1; Average Per-unit Use : 5; Unit of Time : Hours; Unit of Calendar : Day: Number of Units : 0; Average Per-unit Use : 0; Unit of Time : Minutes; Unit of Calendar : Day; Number of Units : 0; Average Per-unit Use : 1; Unit of Time : Hours; Unit of Calendar : Week; Number of Units : 1; Average Per-unit Use : 1; Unit of Time : Hours; Unit of Calendar : Week; Number of Units : 1; Average Per-unit Use : 5; Unit of Time : Hours; Unit of Calendar: Day; Number of Units : 0; Average Per-unit Use : 4; Unit of Time : Minutes; Unit of Calendar : Day; Energy Star : No; Number of Units : 0; Average Per-unit Use : 4; Unit of Time : Minutes; Unit of Calendar : Day 131mber of Units : 0; Average Per-unit Use : 30; Unit of Time : Minutes; Unit of Calendar : Day; Average Per-unit Use : 0; Unit of Time : Hours; Unit of Calendar : Day; 


\section{Miscellaneous Kitchen Equipment}

Bottled Water (With heating or chilling ability) : Day; Energy Star Qualified : No; Instant Hot Water : No; Number of Units : 0; Average Per-unit Use : 1; Unit of Time : Hours; Unit of Calendar : Week; Number of Units : 1; Average Per-unit Use : 30; Unit of Time : Minutes; Unit of Calendar : Day; Average Per-unit Use : 1; Unit of Time : Hours; Unit of Calendar : Day; Number of Units : 0; Average Per-unit Use : 30; Unit of Time : Minutes; Unit of Calendar : Day; Average Per-unit Use : 1; Unit of Time : Hours; Unit of Calendar : Day; Number of Units : 0; Average Per-unit Use : 0; Unit of Time : Minutes; Unit of Calendar : Week; Number of Units : 0; Average Per-unit Use : 0; Unit of Time : Hours; Unit of Calendar : Month; Number of Units : 0; Average Per-unit Use : 1; Unit of Time : Hours; Unit of Calendar : Week; Number of Units : 1; Average Per-unit Use : 1; Unit of Time : Minutes; Unit of Calendar : Day; Number of Units : 0; Average Per-unit Use : 0; Unit of Time : Hours; Unit of Calendar : Week; Number of Units : 1; Average Per-unit Use : 6; Unit of Time : Minutes; Unit of Calendar : Day; Number of Units : 0; Average Per-unit Use : 4; Unit of Time : Minutes; Unit of Calendar : Day; Average Per-unit Use : Day; Unit of Time : Minutes; Unit of Calendar : Day;

\section{Other Appliances}

Number of Units : 0; Number of Units : 0; Average Per-unit Use : 1; Unit of Time : Hours; Unit of Calendar : Week; Number of Units : 1; Average Per-unit Use : 1; Unit of Time : Hours; Unit of Calendar : Week; Number of Units : 0; Average Per-unit Use : 24; Unit of Time : Hours; Unit of Calendar : Day; Number of Units : 0; Average Per-unit Use : 1; Unit of Time : Hours; Unit of Calendar : Day; Months in the year : 4; Number of Units : 2; Number of Units : 0; Average Per-unit Use : 24; Unit of Time : Hours; Unit of Calendar : Day; Energy Star : No; Number of Units : 1; Number of Units : 1; Average Per-unit Use : 5; Unit of Time : Hours; Unit of Calendar : Day; Months in year : 4; Number of Units : 0; Average Per-unit Use : 1; Unit of Time : Hours; Unit of Calendar : Day; Months in year : 4; Number of Units : 0; Average Per-unit Use : 24; Unit of Time : Hours; Unit of Calendar : Day; Energy Star : No; Number of Units : 0; Average Per-unit Use : 8; Unit of Time : Minutes; Unit of Calendar : Day; Number of Units : 1; Average Per-unit Use : 7; Unit of Time : Minutes; Unit of Calendar : Day; Number of Units : 0; Average Per-unit Use : 1; Unit of Time : Hours; Unit of Calendar : Day; Months in year : 4; Number of Units : 0; Average Per-unit Use : 24; Unit of Time : Hours; Unit of Calendar : Day; Number of Units : 1; Average Per-unit Use : 20; Unit of Time : Minutes; Unit of Calendar : Week; Number of Units : 0; Average Per-unit Use : 2; Unit of Time : Hours; Unit of Calendar : Day; Months in year : 4; Number of Units : 0; Number of Units : 0; Average Per-unit Use : 1; Unit of Time : Hours; Unit of Calendar : Day; Months in year : 4; Number of Units : 0; Average Per-unit Use : 6; Unit of Time : Hours; Unit of Calendar : Week; Number of Units : 0; Name : ; Average Per-unit Use : 0; Unit of Time : Minutes; Unit of Calendar : Day; Watts : ; Number of Units : 0; Name : ; Average Per-unit Use : 0; Unit of Time : Minutes; Unit of Calendar : Day; Watts : ; Number of Units : 0; Name : ; Average Per-unit Use : 0; Unit of Time : Minutes: Unit of Calendar : Day; Watts : ; Number of Units : 0; Name : ; Average Per-unit Use : 0; Unit of Time : Minutes; Unit of Calendar : Day; Watts : ; Number of Units : 0; Name : ; Average Per-unit Use : 0; Unit of Time : Minutes; Unit of Calendar : Day; Watts : ;

\section{House Shape Size}

Conditioned floor area (all stories combined) ?: 1113; Direction faced by front of house : North; Stories above ground level : 1; Interior floor-to-ceiling height : 8 feet; Rectangle : ; L-Shape : ; Front S-Shape : ; Back S-Shape : ; T-Shape : ; U-Shape : ; Split- or Tri- Level : ; Townhouse : ; Front door is on Top Side : ; Front door is on Right Side : ; Front door is on Bottom Side : ; Front door is on Left Side : ; Length of the house (from front to back) $\mid r$ : 25.84; Width of the house (from left to right) $\mid r$ : 43.07; Front door is on Top Side : ; Front door is on Right Side : ; Front door is on Bottom Side : ; Front door is on Left Side : ; Side 1 Dimension : 10.00; Side 2 Dimension : 10.00; Side 3 Dimension : 43.07; Side 4 Dimension : 25.84; Front door is on Top Side : ; Front door is on Right Side : ; Front door is on Bottom Side : ; Front door is on Left Side : ; Side 1 Dimension : 10.00; Side 2 Dimension : 10.00; Side 3 Dimension : 10.00; Side 4 Dimension : 10.00; Side 3 Dimension : 43.07 ; Side 4 Dimension : 25.84 ; Front door is on Top Side : ; Front door is on Right Side : ; Front door is on Bottom Side : ; Front door is on Left Side : ; Side 1 Dimension : 10.00; Side 2 Dimension : 10.00; Side 3 Dimension : 10.00; Side 4 Dimension : 10.00; Side 3 Dimension : 43.07; Side 4 Dimension : 25.84; Front door is on Top Side : ; Front door is on Right Side : ; Front door is on Bottom Side : ; Front door is on Left Side : ; Side 1 Dimension : 43.07; Side 2 Dimension : 10.00; Side 3 Dimension : 10.00; Side 4 Dimension : 10.00; Side 3 Dimension : 25.84; Side 4 Dimension : 10.00; Front door is on Top Side : ; Front door is on Right Side : ; Front door is on Bottom Side : ; Front door is on Left Side : ; Side 1 Dimension : 10.00; Side 2 Dimension : 10.00; Side 3 Dimension : 10.00; Side 4 Dimension : 43.07; Side 3 Dimension : 25.84; Side 4 Dimension : 10.00; Front door is on Top Side : ; Front door is on Right Side : ; Front door is on Bottom Side : ; Front door is on Left Side : ; Side 1 Dimension : 10.00; Side 2 Dimension : 10.00; Side 3 Dimension : 43.07; Side 4 Dimension : 25.84; Front door is on Top Side : ; Front door is on Right Side : ; Front door is on Bottom Side : ; Front door is on Left Side : ; Front door is on Right Side : ; Front door is on Bottom Side : ; Front door is on Left Side : ; Length of the house (from front to back) اr : 25.84; Width of the house (from left to right) $\backslash \mathrm{r}:$ : 43.07;

\section{Skylights}

Single-pane, clear : : Single-pane, tinted : : Double-pane, clear : ; Double-pane, tinted : ; Double-pane, solar-control low-E : ; Double-pane, clear : ; Double-pane, tinted : ; Double-pane, solar-control low-E : ; Double-pane, insulating low-E, argon gas fill : ; Single-pane, clear : ; Double-pane, clear : ; Double-pane, tinted : ; Double-pane, solarcontrol low-E : ; Double-pane, solar-control low-E, argon gas fill : ; Double-pane, insulating low-E : ; Double-pane, insulating low-E, argon gas fill : ; Triple-pane, insulating low-E, argon gas fill : ; Skylight U-Factor : $\mathbf{0 . 0 0}$; Skylight Solar heat gain coefficient : $\mathbf{0 . 0 0}$; Enter the R-value of movable skylight insulation : 0.00 ; Select the type of movable interior skylight shades : None; Skylight size : 0.00 ; 


\section{YEARLY ENERGY COSTS}

Providing more details will make your results more accurate.

\begin{tabular}{|l|l|} 
Existing Home & $\$ 1,032$ \\
With Upgrades & $\$ 812$
\end{tabular}

\begin{tabular}{|c|c|c|c|c|c|c|c|}
\hline & Total & Heating & Cooling & Hot Water & $\begin{array}{c}\text { Large } \\
\text { Appliances }\end{array}$ & $\begin{array}{c}\text { Small } \\
\text { Appliances }\end{array}$ & Lighting \\
\hline Existing Home & $\$ 1,032$ & $\$ 57$ & $\$ 11$ & $\$ 237$ & $\$ 400$ & $\$ 229$ & $\$ 98$ \\
\hline $\begin{array}{l}\text { With } \\
\text { Upgrades }\end{array}$ & $\$ 812$ & $\$ 57$ & $\$ 11$ & $\$ 106$ & $\$ 311$ & $\$ 229$ & $\$ 98$ \\
\hline Savings & $\$ 220$ & $\$ 0$ & $\$ 0$ & $\$ 131$ & $\$ 89$ & $\$ 0$ & $\$ 0$ \\
\hline
\end{tabular}

Important Note: These are initial estimates only, and results may vary. If the owner has not already done so, we strongly recommend that they retain a professional energy auditor to develop a detailed work scope and budget for improving the home. We also recommend the Home Performance with ENERGY STAR program when considering home improvements. 
YEARLY WHOLE HOUSE RESULTS

\section{Existing Home With Upgrades Savings Percentage}

\begin{tabular}{|c|c|c|c|c|c|}
\hline & & Existing Home & With Upgrades & Savings & $\begin{array}{l}\text { Percentage } \\
\text { Reductions }\end{array}$ \\
\hline \multirow{4}{*}{ Whole House } & Energy Bill & $\$ 1,032$ & $\$ 812$ & $\$ 220$ & $21.3 \%$ \\
\hline & Electricity & $4279 \mathrm{kWh}$ & $3596 \mathrm{kWh}$ & $683 \mathrm{kWh}$ & $16 \%$ \\
\hline & Natural Gas & 328 Therms & 229 Therms & 99 Therms & $30.2 \%$ \\
\hline & Emissions & $5967 \mathrm{CO} 2$ & $4467 \mathrm{CO} 2$ & $1500 \mathrm{lb} . \mathrm{CO}_{2}$ & $25.1 \%$ \\
\hline \multirow{3}{*}{ Heating } & Energy Bill & $\$ 57$ & $\$ 57$ & $\$ 0$ & $0 \%$ \\
\hline & Natural Gas & 45 Therms & 45 Therms & 0 Therms & $0 \%$ \\
\hline & Emissions & $526 \mathrm{lb} . \mathrm{CO}_{2}$ & $526 \mathrm{lb} . \mathrm{CO}_{2}$ & $0 \mathrm{lb} \cdot \mathrm{CO}_{2}$ & $0 \%$ \\
\hline \multirow{3}{*}{ Cooling } & Energy Bill & $\$ 11$ & $\$ 11$ & $\$ 0$ & $0 \%$ \\
\hline & Electricity & $75 \mathrm{kWh}$ & $75 \mathrm{kWh}$ & $0 \mathrm{kWh}$ & $0 \%$ \\
\hline & Emissions & $37 \mathrm{lb} . \mathrm{CO}_{2}$ & $37 \mathrm{lb} . \mathrm{CO}_{2}$ & $0 \mathrm{lb} . \mathrm{CO}_{2}$ & $0 \%$ \\
\hline \multirow{3}{*}{$\underline{\text { Hot Water }}$} & Energy Bill & $\$ 237$ & $\$ 106$ & $\$ 131$ & $55.3 \%$ \\
\hline & Natural Gas & 187 Therms & 84 Therms & 103 Therms & $55.1 \%$ \\
\hline & Emissions & $2185 \mathrm{lb} . \mathrm{CO}_{2}$ & $981 \mathrm{lb} . \mathrm{CO}_{2}$ & $1204 \mathrm{lb} . \mathrm{CO}_{2}$ & $55.1 \%$ \\
\hline \multirow{4}{*}{ Large Appliances } & Energy Bill & $\$ 400$ & $\$ 311$ & $\$ 89$ & $22.3 \%$ \\
\hline & Electricity & 1931 kWh & 1248 kWh & 683 kWh & $35.4 \%$ \\
\hline & Natural Gas & 96 Therms & 100 Therms & -4 Therms & $-4.2 \%$ \\
\hline & Emissions & $2085 \mathrm{lb} . \mathrm{CO}_{2}$ & $1788 \mathrm{lb} . \mathrm{CO}_{2}$ & $297 \mathrm{lb} . \mathrm{CO}_{2}$ & $14.2 \%$ \\
\hline \multirow{3}{*}{ Small Appliances } & Energy Bill & $\$ 229$ & $\$ 229$ & $\$ 0$ & $0 \%$ \\
\hline & Electricity & $1590 \mathrm{kWh}$ & $1590 \mathrm{kWh}$ & $0 \mathrm{kWh}$ & $0 \%$ \\
\hline & Emissions & $793 \mathrm{lb} . \mathrm{CO}_{2}$ & $793 \mathrm{lb} . \mathrm{CO}_{2}$ & $0 \mathrm{lb} . \mathrm{CO}_{2}$ & $0 \%$ \\
\hline \multirow{3}{*}{ Lighting } & Energy Bill & $\$ 98$ & $\$ 98$ & $\$ 0$ & $0 \%$ \\
\hline & Electricity & $683 \mathrm{kWh}$ & $683 \mathrm{kWh}$ & $0 \mathrm{kWh}$ & $0 \%$ \\
\hline & Emissions & $341 \mathrm{lb} . \mathrm{CO}_{2}$ & $341 \mathrm{lb} . \mathrm{CO}_{2}$ & $0 \mathrm{lb} \cdot \mathrm{CO}_{2}$ & $0 \%$ \\
\hline
\end{tabular}

Heating electricity values include fan or pumping energy for homes that have forced-air or water-based heating systems powered by circulation pumps. The values for Hot Water include taps and faucets only; the energy consumed by the water heater to supply hot water for appliances such as clothes washers and dishwashers is included instead in the rows for those appliances. 
YEARLY HEATING AND COOLING RESULTS

Show Details

Total Cost

\begin{tabular}{ll} 
Cost & $\$ 68$ \\
Heating & $\$ 57$ \\
Cooling & $\$ 11$ \\
& \\
& Total Energy \\
\hline
\end{tabular}

Energy Use

45 therms $75 \mathrm{kWh}$

Heating

45 therms

Cooling

$75 \mathrm{kWh}$

Notes: this house is $37 \%$ heated by wood fuel.

$19 \%$ of the floor area is heated and $100 \%$ cooled.

Heating electricity values include fan or pumping energy for homes that have forced-air or water-based heating systems powered by circulation pumps.

What if my results don't match my energy bill?

\section{HOME ENERGY SAVER"}

YEARLY LARGE APPLIANCES AND WATER HEATING RESULTS

Show Details

\begin{tabular}{l|r|}
\hline Appliance & $\begin{array}{r}\text { Total } \\
\text { Cost }\end{array}$ \\
\hline First Refrigerator & $\$ 124$ \\
\hline Stove & $\$ 42$ \\
\hline Oven & $\$ 34$ \\
\hline Clotheswasher & $\$ 117$ \\
\hline Clothesdryer & $\$ 90$ \\
\hline Dishwasher & $\$ 51$ \\
\hline Hot Water: Taps and & $\$ 237$ \\
Faucets & \\
\hline Totals & $\$ 637$
\end{tabular}

Equipment energy is the energy used by motors, heating elements, and burners inside your appliances. This number excludes the energy consumed by your water heater to supply hot water for appliances such as clothes washers and dishwashers (which is included instead in the rows for those appliances).

What if my results don't match my energy bill? 
YEARLY SMALL APPLIANCES RESULTS

Show Details $?$

$\begin{array}{lrr}\text { Category } & \text { Energy Use } & \text { Energy Costs } \\ \text { Entertainment } & 345 \mathrm{kWh} & \mathbf{\$ 5 0} \\ \text { HomeOffice } & 361 \mathrm{kWh} & \mathbf{\$ 5 2} \\ \text { Kitchen } & 470 \mathrm{kWh} & \mathbf{\$ 6 8} \\ \text { Other } & 382 \mathrm{kWh} & \mathbf{\$ 5 5}\end{array}$

What if my results don't match my energy bill?

\section{H. HOME ENERGY SAVER}

YEARLY LIGHTING RESULTS

Here is the calculated Yearly lighting bill based on the inputs you provided:

Show Details 2

$\begin{array}{lrr}\text { Room } & \text { Energy Use } & \text { Energy Costs } \\ \text { All Bathrooms } & 108 \mathrm{kwh} & \mathbf{\$ 1 6} \\ \text { All Bedrooms } & 22 \mathrm{kwh} & \mathbf{\$ 3} \\ \text { Kitchen } & 132 \mathrm{kwh} & \mathbf{\$ 1 9} \\ \text { Living Room } & 132 \mathrm{kwh} & \mathbf{\$ 1 9} \\ \text { Master Bedroom } & 72 \mathrm{kwh} & \mathbf{\$ 1 0} \\ \text { Outdoor Lighting } & 143 \mathrm{kwh} & \mathbf{\$ 2 1} \\ \text { Utility Room } & 74 \mathrm{kwh} & \mathbf{\$ 1 1}\end{array}$

What if my results don't match my energy bill? 
UPGRADE RECOMMENDATIONS SUMMARY

Visit 'Recommendations' to see more information on each upgrade.

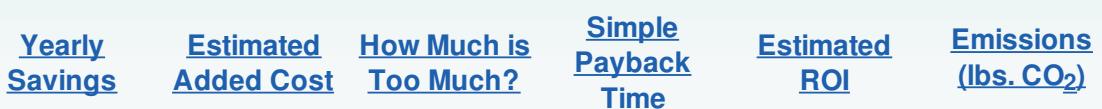

\section{Total for}

recommended

$\$ 235$

$\$ 510$

$\$ 2350$

2

$45 \%$

1500

upgrades

Important Note: These are initial estimates only, and results may vary. If the owner has not already done so, we strongly recommend that they retain a professional energy auditor to develop a detailed work scope and budget for improving the home. We also recommend the Home Performance with ENERGY STAR program when considering home improvements.

Upgrades Requiring Investment
1. Indoor lights
2. Electric clothes dryer
3. Gas water heater
4. Clothes washer

Other benefits that often come along with these energy-saving upgrades

- Fluorescent lamps last several times longer than ordinary incandescent bulbs, which saves you the time and expense of replacing bulbs when they burn out.

- Natural gas clothes dryers reduce your home's peak load on the power grid compared to an electric dryer.

- Efficient gas-fired water heaters may hold their temperature longer following power interruptions and operate more safely

- ENERGY STAR® clothes washers can reduce water use significantly, leave the clothes drier thus reducing drying time and energy consumption, and reduce wear and tear on clothes. 


\section{UPGRADE RECOMMENDATIONS ?}

What efficiency level would you like to model for the initial selection of upgrades?

EnergyStar

What simple payback period would you like to use for selecting 10 * upgrades?

Rows that are dimmed are not included in the calculated values for the retrofit package.

To include them check their boxes and recalculate.

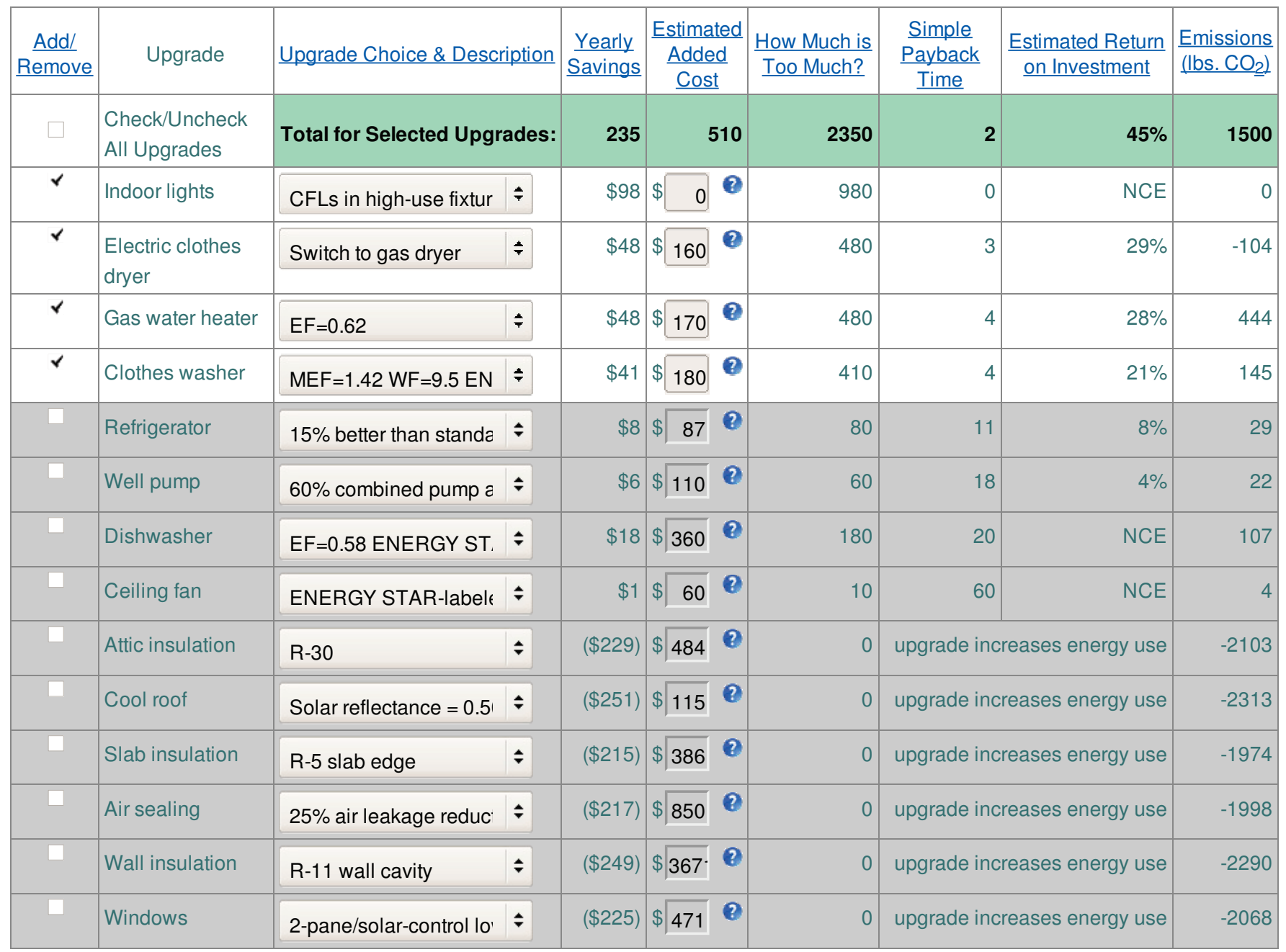

Important Note: These are initial estimates only, and results may vary. If the owner has not already done so, we strongly recommend that they retain a professional energy auditor to develop a detailed work scope and budget for improving the home. We also recommend the Home Performance with ENERGY STAR program when considering home improvements.

NCE $=$ Not Cost Effective. This upgrade will not pay for itself in your situation. There may be other reasons, such as improved comfort, to implement the upgrade, or it could be made more cost-effective if the investment cost is reduced.

Note: Each of the upgrades in the table above are evaluated in isolation from the others. If the efficiency level is changed for one upgrade, its potential impact on other upgrades will not be counted in the row-by-row estimates. However, these kinds of interactions are included in the "package" totals associated with the whole-house totals and chart at the top of the page, for the upgrades selected as part of the package. For example, if the furnace efficiencies are raised, the energy savings from wall insulation will not change in the row estimate, but the incremental savings from including insulation in the package will be less due to the more efficient furnace's impact on reducing the energy required to make up heat losses through the wall (there is less energy being used, so less to save). 


\section{DETAILED UPGRADE RECOMMENDATIONS REPORT}

This is a printable report of the upgrades selected for the home. These upgrades have the potential to save $\$ 220$ each year on the utility bill.

Upgrade Package Summary: Estimate Yearly Bill Savings:

Estimated Lifetime Energy Savings:

Estimated Added Cost:

Maximum Price for 10 Year Payback:

Return on Investment:

Upgrade Pays for Itself in:

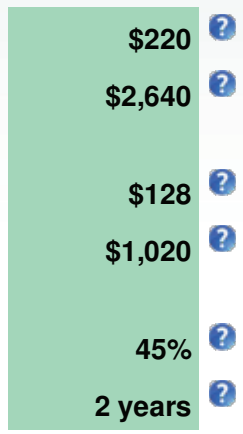

\section{You selected the following upgrades:}

- Replace high use incandescent lamps with compact fluorescent lamps

- When replacing your electric clothes dryer, switch to natural gas model

- When replacing your gas water heater, choose an energy efficient model

- When replacing your clothes washer, choose an ENERGY STAR-labeled model

Note: The economic benefits for each of the upgrades below are evaluated in isolation from the other upgrades. If the efficiency level is changed for one upgrade, its potential impact on other upgrades will not be counted in the individual upgrade estimates. However, these kinds of interactions are included in the "package" totals associated with the whole-house totals and chart at the top of the page (above). For example, if the furnace efficiency is increased, the energy savings from wall insulation will not change in the table below, but the incrementa savings from including insulation in the package will be less due to the more efficient furnace's impact on reducing the energy required to make up heat losses through the wall (there is less energy being used, so less to save).

Replace high use incandescent lamps with compact fluorescent lamps

Economic Benefits:

Estimate Yearly Bill Savings:

Estimated Lifetime Energy

$\$ 1,176$

Savings:

Estimated Added Cost:

Maximum Price for 10 Year

Payback:

Return on Investment:

Upgrade Pays for Itself in:

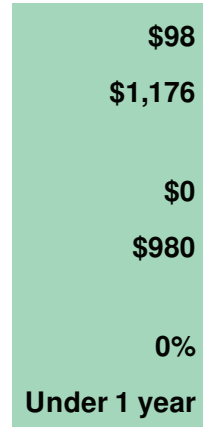

Additional Benefits:

Fluorescent lamps last several times longer than ordinary incandescent bulbs, which saves you the time and expense of replacing bulbs when they burn out.

\section{Upgrade Description:}

Replace high-use incandescent lamps with compact fluorescent lamps. These units can save up to $75 \%$ of the energy used by an ordinary incandescent bulb.

\section{Purchasing Tips:}

- Compare the light output in Lumens of the bulb you are replacing to ensure you are using the appropriate CFL. Most CFLs list their light output and equivalent incandescent wattage on their package.

- CFLs are available in many shapes and sizes, which will allow replacing nearly any incandescent bulb.

- When buying new light fixtures, look for ENERGY STAR qualified models.

- CFLs are a good investment for lights that are used 2-3 hours per day on average or more. 


\section{When replacing your electric clothes dryer, switch to natural gas model}

\section{Economic Benefits:}

Estimate Yearly Bill Savings:

Estimated Lifetime Energy

Savings:

\section{Estimated Added Cost:}

Maximum Price for 10 Year Payback:

Return on Investment:

Upgrade Pays for Itself in:

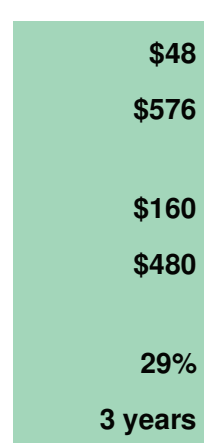

\section{Additional Benefits:}

Natural gas clothes dryers reduce your home's peak load on the power grid compared to an electric dryer.

\section{Upgrade Description:}

When replacing your electric clothes dryer, select a natural gas model. In many situations, this willreduce your overall energy bill because natural gas tends to cost less than electricity, for the same heating value.

Note: Our calculations bill savings, typical upgrade costs, and cost-effectiveness are for a minimum-efficiency natural gas dryer model. The defaultupgrade cost provided here assumes that a natural gas connection is available at your clothes dryer. If this is not the case, be sure to include the costof extending

\section{Purchasing Tips:}

- To use a gas dryer, your laundry room must have a gas hookup, with proper connections and safe venting of the gas's exhaust, in addition to an electrical outlet

- Look for a dryer with a moisture sensor, and use the dryness settings rather than timed drying.

- When replacing your clothes washer, choose a model with high-speed spin cycles. This feature removes more water from clothes, which reduces the energy and time required for drying.

\section{More Information:}

- General Information from DOE

- Laundry tips from ACEEE

- Information from the California Energy Commission

\section{When replacing your gas water heater, choose an energy efficient model}

Economic Benefits:

Estimate Yearly Bill Savings:

Estimated Lifetime Energy

Savings:

Estimated Added Cost:

Maximum Price for 10 Year

Payback:

Return on Investment:

Upgrade Pays for Itself in:

\section{Additional Benefits:}

Efficient gas-fired water heaters may hold their temperature longer following power interruptions and operate more safely.

\section{Upgrade Description:}

When replacing your gas water heater, choose an energy-efficient model with an Energy Factor of 0.62 or higher.

Note: Our calculations bill savings, typical upgrade costs, and cost-effectiveness assume the efficient water heater has an energy factor of 0.62 and recovery efficiency of 0.76 . Higher efficiency units are available, and would provide additional energy savings.

\section{Purchasing Tips:}

- The most important measure of efficiency for water heaters is the Energy Factor EF. The higher the EF, the more efficient the water 
- Purchase a water heater whose tank is internally insulated with at least R-16. $\underline{5}$

- A water heater that is too large for your home not only has a higher purchase cost but will increase your energy costs due to excessive cycling and standby losses. The resources below provide good, simple guidance on proper sizing of water heaters. The size, or "capacity", of a fuel-fired water heater should be judged by its first hour rating FHR, not its tank size. Due to larger burners, some gas water heaters with smaller tanks actually have higher capacities FHRs than models with larger tanks.

- Many types of water heaters are now available, such as "demand" tankless, "indirect" or "integrated", and solar-assisted water heaters. More Information

- New and/or efficient gas water heaters may have different venting and flue requirements. When replacing your water heater make sure your contractor assesses your existing flue, follows new code requirements for venting water heaters, and obtains necessary permits and inspections. $\underline{3}$

\section{More Information:}

- General Information from DOE

- DOE Water Heating fact sheet

- Top-Rated Energy-EfficientWater Heaters from ACEEE

- GAMA consumer's directory click on "Consumers"

- How to prevent health and safety problems with combustion equipment

\section{When replacing your clothes washer, choose an ENERGY STAR-labeled model}

\section{Economic Benefits:}

Estimate Yearly Bill Savings:

Estimated Lifetime Energy

Savings:

Estimated Added Cost:

Maximum Price for 10 Year

Payback:

Return on Investment:

Upgrade Pays for Itself in:

\section{Additional Benefits:}

ENERGY STAR® clothes washers can reduce water use significantly, leave the clothes drier thus reducing drying time and energy consumption, and reduce wear and tear on clothes.

\section{Upgrade Description:}

When replacing your clothes washer, choose an ENERGY STAR-labeled model. ENERGY STAR clothes washers can reduce energy consumption by up to $70 \%$ and are available in top-loading and front-loading designs. Some ENERGY STAR models use up to $50 \%$ less water in addition to saving energy.

Note: Our calculations bill savings, typical upgrade costs, and cost-effectiveness are for a model with the lowest efficiency that qualifies for the ENERGY STAR label.

\section{Purchasing Tips:}

- Choose a clothes washer with high-speed spin cycles. This feature removes more water from clothes, which reduces the energy and time required for drying.

- Select a low water-use, high efficiency washer. Front-loading tumble-action washers can cut energy use by up to 70 percent, reduce water consumption significantly, and may actually get clothes cleaner. 1

- Look for pre-soaking and/or "suds saver" options which conserve energy.

- Clothes washers come with EnergyGuide yellow and black labels. Use these labels to select the most efficient model for the capacity you have chosen.

\section{More Information:}

- ENERGY STAR clothes washer product list

- General Information from DOE

- Top-Rated Energy-Efficient Clothes Washers from ACEEE 
ROADMAP TO RESULTS

Ease into the process of making your home more efficient. If you're new to this, or you're on a very tight budget, start with the lowest-hanging fruit like double-checking your water heater's temperature setting.

The next easy steps are simple things that will fit into your shopping basket: maybe a few compact fluorescent lamps or a roll of weatherstripping.

When it's time to replace that old fridge, or other appliances, take time to shop smart. At a minimum, look for the ENERGY STAR rating. There are detailed lists of products that will take you even farther. Remember: you're not simply spending money, you're investing for profit and comfort.

Redoing your kitchen? New roof? Finally adding that in-law unit? Creating successful projects can take some work. Take the time to find a home performance specialist to help you think thru all the options ahead of time, and then find the right contractor with the skills to do the job right.

Not only will these upgrades pay for themselves many times over, there are all kinds of financial incentives to help you trim the cost. And many of the "non-energy benefits" will be worth more than money can buy.

And, don't forget about saving water (which also saves energy).

Stumped? Ask an expert.

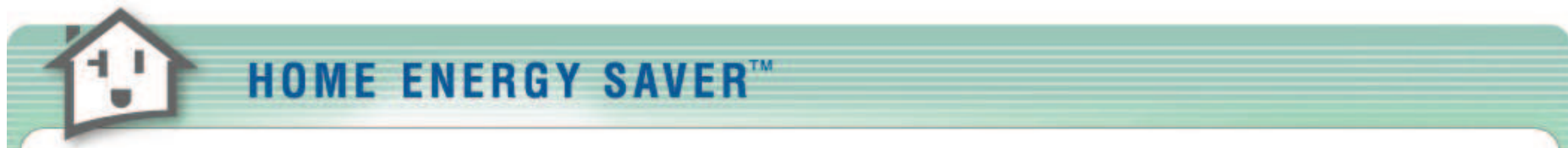

\section{DISCLAIMER}

The Home Energy Saver website and related content were prepared as an account of or to expedite work sponsored at least in part by the United States Government. While we strive to provide correct information, neither the United States Government nor any agency thereof, nor The Regents of the University of California, nor any of their employees, makes any warranty, express or implied, or assumes any legal responsibility for the accuracy, completeness, or usefulness of any information, apparatus, product, or process disclosed, or represents that its use would not infringe privately owned rights. Reference herein to any specific commercial product, process, or service by its trade name, trademark, manufacturer, or otherwise, does not necessarily constitute or imply its endorsement, recommendation, or favoring by the United States Government or any agency thereof, or The Regents of the University of California. Use of the Laboratory or University's name for endorsements is prohibited. The views and opinions of authors expressed herein do not necessarily state or reflect those of the United States Government or any agency thereof or The Regents of the University of California. Neither Berkeley Lab nor its employees are agents of the US Government.

Berkeley Lab web pages link to many other websites. Such links do not constitute an endorsement of the content or company and we are not responsible for the content of such links.

\section{Information That You Voluntarily Provide}

We do not collect personal information unless you choose to provide it to us. If you provide us with personal information, for example your address, we use that information to provide better information to you through the Home Energy Saver, as well as to further our research. While we strive to protect your personal information, our Laboratory conducts open fundamental research and cannot guarantee or warrant that your information will never be compromised or disclosed.

\section{How Information is Used}

The information you provide on this site is used to provide the service to you, to improve the service, and to conduct and support research by Berkeley Lab researchers and their collaborators.

\section{Information Protection}

For site security purposes and to ensure that this service remains available to all users, this University of California computer system employs software programs to monitor network traffic to identify unauthorized attempts to upload or change information, or otherwise cause damage. If such monitoring reveals evidence of possible abuse or criminal activity, such evidence may be provided to appropriate law enforcement officials. We may also share this information with other affiliated institutions in order to help secure other systems and networks. Unauthorized attempts to upload or change information on this server are strictly prohibited and may be punishable under California and Federal law.

\section{Sharing of Information}

We may share the information you choose to provide to us with our research collaborators and our partners who help to provide this service. We may share the information you provide to us with the Department of Energy and other Federal Agencies. Information you share with us may also be covered by California and Federal laws that provide for mandatory disclosure under certain circumstances, such as subpoenas and records requests.

A full description of the privacy policy and disclaimers can be found at the following web site 
Appendix E - Water Usage Under Baseline, Original and Alternative Configurations

\section{Baseiline Wuter Ueage \\ GENERAL OUESTIONS}

1. Total number of people in your household. (Required)

INDOOR WATER USE

\section{BATHROOM}

1. How mary showers are taken each day in your household?

2. What is the average length (in minutes) of each shower Enter 6.3 if you are unsure.

3. What is the flow rate (gallons per minute) of your showerhead? Enter $\mathbf{5}$ for standard showerhead: 2 for low flow.

4. Total number of baths taken each week by members of your household

\section{TOILETS}

1. Average number of times each person flushes a toilet in your house per day Enter $\mathbf{4}$ if you are unsure.

2. How many gallons does your toilet use per flush? Enter 5 if you have a standard tollet: 1.6 if you have a low volume toilet.

\section{FAUCETS}

1. How mary times each day does each household member use faucets to shave, brush teeth, wash hands and face?

2. How many minutes does the water run during each use?

\section{WASHING DISHES}

1. How many times are dishes washed by hand each day?

2. How many minutes does the water run during each wash?

3. If you have a dishwasher, how many times is it used each week?

4. The average dishwasher uses 15 gallons of water per load, change this number if yours is different.

\section{LAUNDRY}

1. How many loads of laundry are done by members of your household each week

2. The average washing machine uses 55 gallons of water per load, change this number if yours is different.

Press the calculate button to compute your overall water use.

\section{Calculate clear form}

\begin{tabular}{|c|c|c|c|}
\hline \multicolumn{4}{|c|}{ RESULTS } \\
\hline \multicolumn{4}{|c|}{ PER CAPITA DAILY WATER USE IN YOUR HOUSEHOLO (gallonS) } \\
\hline INDOOR WATER USE & & OUTDOOR WATER USE & \\
\hline Bathroom & 100 & Lawn watering & 0 \\
\hline Toilets & 20 & Other Outdoor Uses & 0 \\
\hline Faucets & 60 & GENERAL WATER USE & \\
\hline Laundry & 10 & & \\
\hline Dishwasher & 1 & & \\
\hline Hand Washing Dishes & 8 & & \\
\hline
\end{tabular}

Monthly Use: 6,050 Annually Use: 72,635 
INDOOR WATER USE

\section{BATHROOM}

1. How many showers are taken each day in your household?

2. What is the average length (in minutes) of each shower. Enter 6.3 if you are unsure.

3. What is the flow rate (gallons per minute) of your showerhead? Enter 5 for standard showerhead: 2 for low flow.

4. Total number of baths taken each week by members of your household

\section{TOILETS}

1. Average number of times each person flushes a tollet in your house per day. Enter 4 if you are unsure.

2. How many gallons does your toilet use per flush? Enter 5 if you have a standard toilet: 1.6 if you have a low volume toilet.

FAUCETS

1. How many times each day does each household member use faucets to shave. brush teeth, wash hands and face?

2. How many minutes does the water run during each use?

\section{WASHING DISHES}

1. How many times are dishes washed by hand each day?

2. How many minutes does the water run during each wash?

3 . If you have a dishwasher, how many times is it used each week?

4. The average dishwasher uses 15 gallons of water per load, change this number if yours is different

\section{LAUNDRY}

1. How many loads of laundry are done by members of your housenoid each week.

2. The average washing machine uses 55 gallons of water per load, change this number if yours is different.

\section{OUTDOOR WATER USE}

\section{LAWN WATERING \& OTHER USES}

1. How many times is your lawn watered each week?

2. How many minutes is the lawn watered per watering?

3. Water is aiso used outdoors to wash cars, fill pools, nnse outdoor furniture and clean equipment. Estimate the average number of minutes water is used outcoors for purposes other than watering each week.

\section{RESULTS}

PER CAPITA DAILY WATER USE IN YOUR HOUSEHOLD (gallonS) INDOOR WATER USE OUTDOOR WATER USE

Bathroom

Toilets

30 Lawn watering

Toilets

5 Other Outdoor Uses

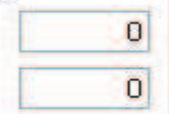

Faucets

Laundry

Dishwasher

Hand Washing Dishes

60 GENERAL WATER USE

Click one of the categories above to learn how to reduce your water usage.

Monthly Use: 3,192 Annually Use: 38,325 


\section{Ahemative Uporades Water Usage \\ GENERAL QUESTIONS}

1. Total number of people in your household. (Required)

INDOOR WATER USE

\section{BATHROOM}

1. How many showers are taken each day in your household?

2. What is the average length (in minutes) of each shower. Enter 6.3 if you are unsure.

3. What is the fiow rate (gallons per minute) of your showerhead? Enter $\mathbf{5}$ for standard showerhead: 2 for low flow.

4. Total number of baths taken each week by members of your household

\section{TOILETS}

1. Average number of times each person flushes a tollet in your house per day Enter 4 if you are unsure.

2. How many gallons does your toilet use per flush?

Enter 5 if you have a standard toilet: 1.6 if you have a low volume toilet.

FAUCETS

1. How many times each day does each household member use faucets to shave, brush teeth, wash hands and race?

2. How many minutes does the water run during each use? WASHING DISHES

1. How many times are dishes washed by hand each day?

2. How many minutes does the water run during each wash?

3. If you have a dishwasher, how many times is it used each week?

4. The average dishwasher uses 15 gallons of water per load, change this number if yours is different.

\section{LAUNDRY}

1. How many loads of laundry are done by members of your household each week.

2. The average washing machine uses 55 gallons of water per load, change this number if yours is different.

\section{OUTDOOR WATER USE}

\section{LAWN WATERING \& OTHER USES}

1. How many times is your lawn watered each week?

2. How many minutes is the lawn watered per watering?

Water is also used outcoors to wash cars, fill pools, rinse outdoor furniture and clean equipment. Estimate the average number of minutes water is used outdoors for purposes other than watering each week.

Press the Calculate button to compute your overall water use. Calculate clear form

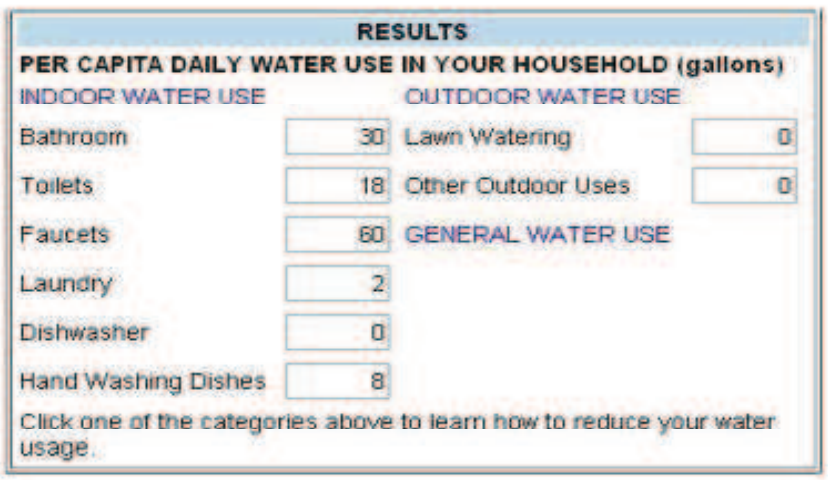

Monthly: 3,587 Annual: 43,070 